SOFÍA LILIANNE VILLAGARCÍA ZEGARRA

\title{
DIRETRIZES PARA A ELABORAÇÃO DE UM MODELO DE GESTÃO DOS FLUXOS DE INFORMAÇÕES COMO SUPORTE À LOGÍSTICA EM EMPRESAS CONSTRUTORAS DE EDIFÍCIOS
}

Dissertação apresentada à Escola Politécnica da Universidade de São Paulo para obtenção do título de Mestre em Engenharia.

São Paulo

2000 
SOFÍA LILIANNE VILLAGARCÍA ZEGARRA

\title{
DIRETRIZES PARA A ELABORAÇÃO DE UM MODELO DE GESTÃO DOS FLUXOS DE INFORMAÇÕES COMO SUPORTE À LOGÍSTICA EM EMPRESAS CONSTRUTORAS DE EDIFÍCIOS
}

\author{
Dissertação apresentada à Escola \\ Politécnica da Universidade de São \\ Paulo para obtenção do título de \\ Mestre em Engenharia. \\ Área de Concentração: \\ Engenharia de Construção Civil e \\ Urbana \\ Orientador: \\ Prof. Dr. Francisco Ferreira Cardoso
}

São Paulo

2000 


\section{FICHA CATALOFRÁFICA}

\section{Villagarcía Zegarra, Sofía Lilianne}

Diretrizes para a elaboração de um modelo de gestão dos fluxos de informações como suporte à logística em empresas construtoras de edifícios, São Paulo, 2000.

$$
214 \mathrm{p} \text {. }
$$

Dissertação (Mestrado) - Escola Politécnica da Universidade de São Paulo. Departamento de Engenharia de Construção Civil.

1. Gestão de Materiais - Fluxos de Informação 2. Construção Civil I. Universidade de São Paulo. Escola Politécnica. Departamento de Engenharia de Construção Civil. II. t. 
Aos meus pais, Teresa e Sven e ao meu esposo Alberto por todo o apoio e amor que sempre me deram. 


\section{AGRADECIMENTOS}

Ao Prof. Dr. Francisco Ferreira Cardoso pela sua orientação, dedicação, amizade e pelo seu apoio constante para concretizar este trabalho.

Aos professores da pós-graduação Dra. Mercia Maria B. de Barros, Dr. Fernando Henrique Sabbatini, Dr. Silvio B. Melhado e Dr. Ubiraci L. de Souza pelo que aprendi nas suas disciplinas que serviu de muito para a realização desta pesquisa.

Aos amigos da pós-graduação Adriano, Artemária, Eliana, Fanny, Fred, Márcio, Júlio, Alberto, Odívio, Rubenio, Rubiane, Yêda e a todos os demais colegas pela sua amizade e companheirismo.

Às empresas construtoras, seus diretores e engenheiros que contribuíram para a realização dos estudos de caso:

Cyrela Construtora Limitada;

Construtora e Incorporadora Gafisa;

Tecnisa Engenharia e Comércio Limitada.

À Fundação de Amparo à Pesquisa do Estado de São Paulo - FAPESP, pelo seu financiamento para a realização desta pesquisa, através de uma bolsa de mestrado. 


\section{SUMÁRIO}

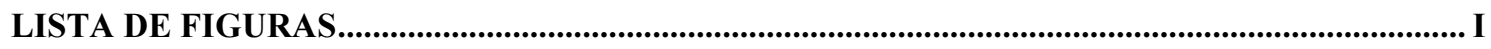

LISTA DE TABELAS ...........................................................................................................................

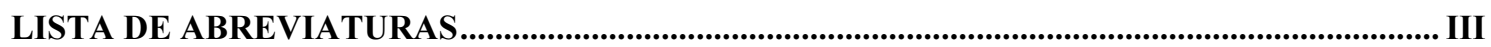

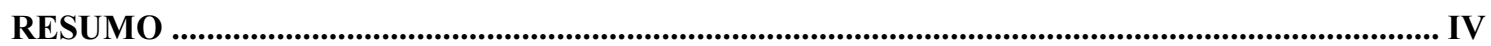

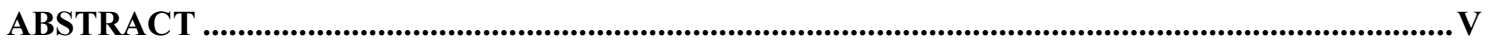

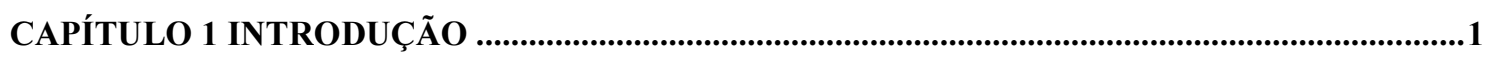

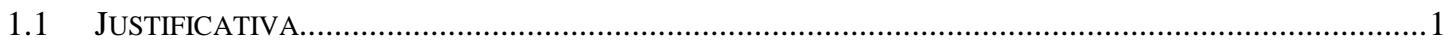

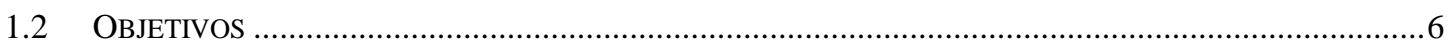

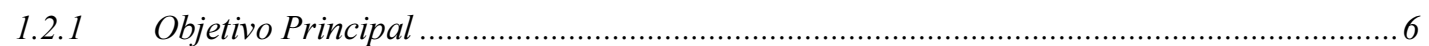

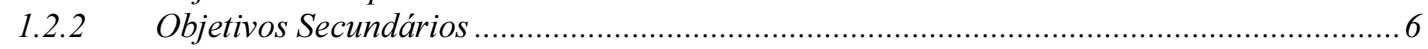

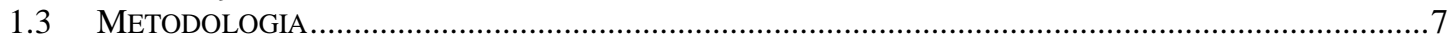

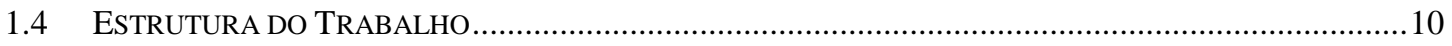

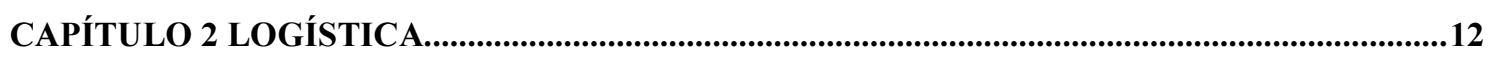

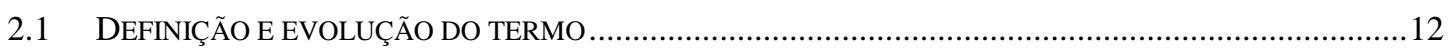

2.1.1 Período de gestão funcional (fim da década de 50 até a década de 70) .............................13

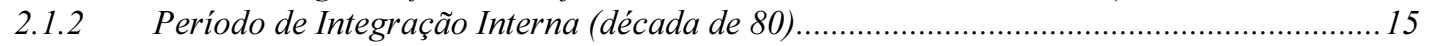

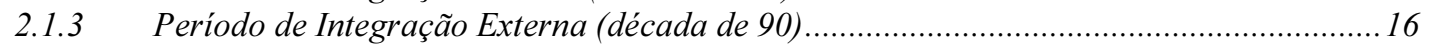

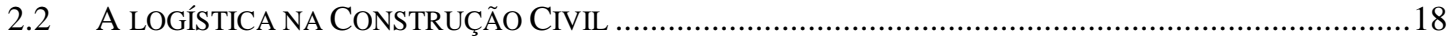

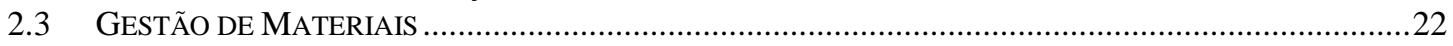

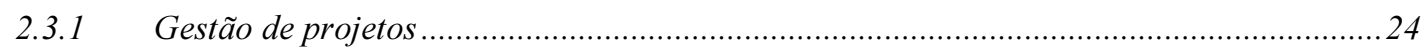

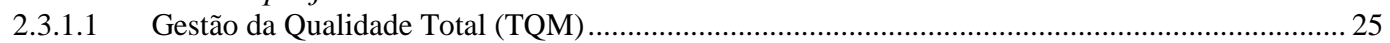

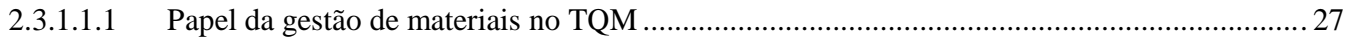

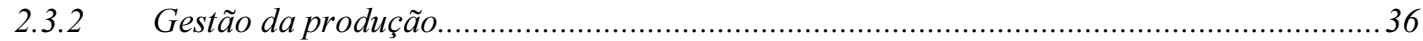

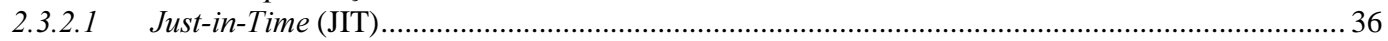

2.3.2.2 Lean Construction (Produção Enxuta) .................................................................................... 39

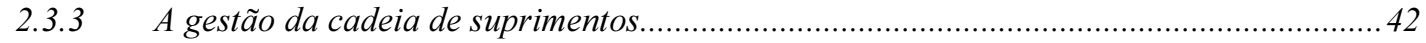

2.3.3.1 A cadeia de suprimentos na industria da construção ....................................................................... 45

2.3.3.2 Fornecedores de materiais e de subsistemas............................................................................ 49

CAPÍTULO 3 A INFORMAÇÃO NO INTERIOR DA ORGANIZAÇÃO.....................................54

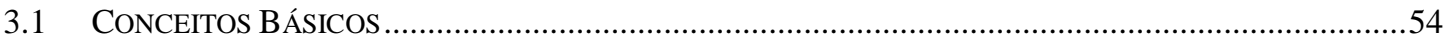

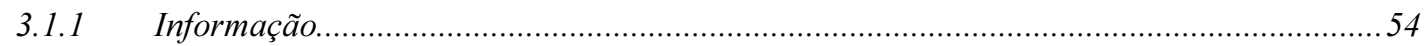

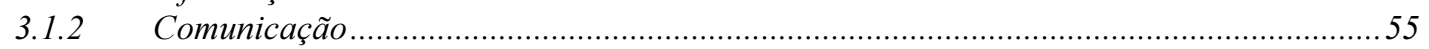

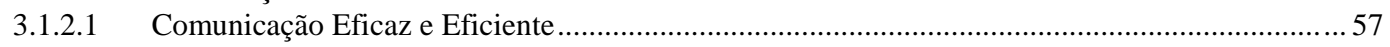

3.2 A ESTRUTURA ORGANIZACIONAL E SEUS FLUXOS DE INFORMAÇÕES ............................................57

3.2.1 A importância da informação no processo de tomada de decisões ......................................65

CAPÍTULO 4 A TECNOLOGIA DA INFORMAÇÃO (TI) .............................................................71

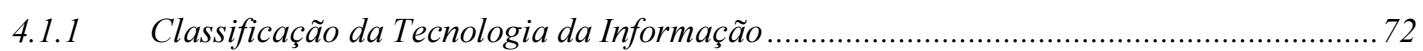

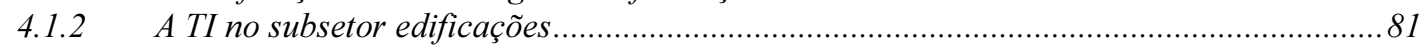

CAPÍTULO 5 MÉTODO DE ANÁLISE DOS FLUXOS DE INFORMAÇÃO...................................85

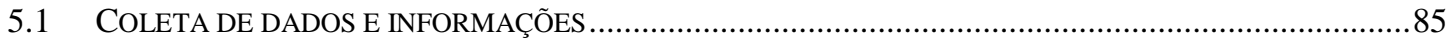

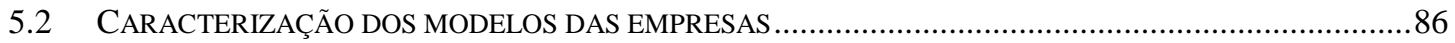

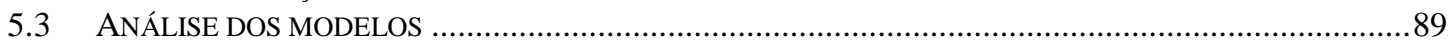

CAPÍTULO 6 ESTUDO DE CASO

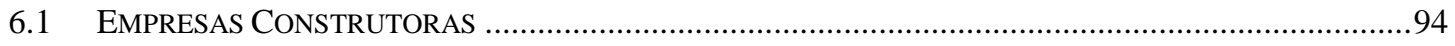

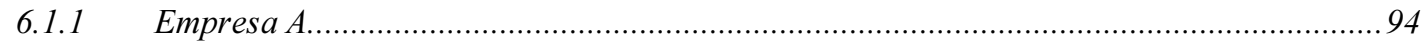

6.1.1.1 Caracterização da Empresa.................................................................................................... 94 
6.1.1.2 Estrutura Organizacional da Empresa .......................................................................... 95

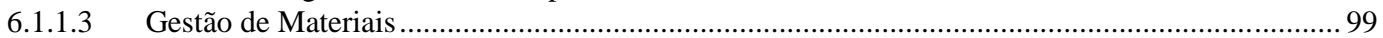

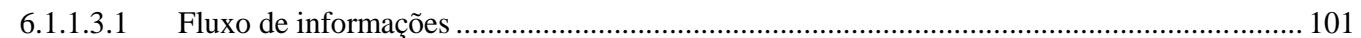

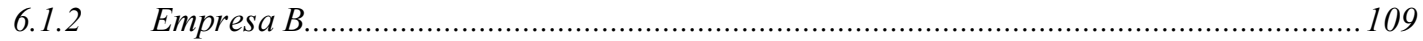

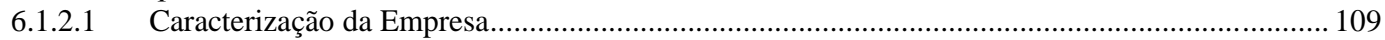

6.1.2.2 Estrutura Organizacional da Empresa ............................................................................ 109

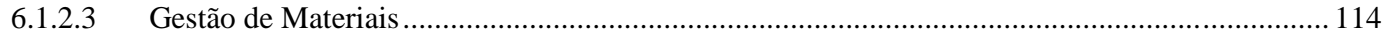

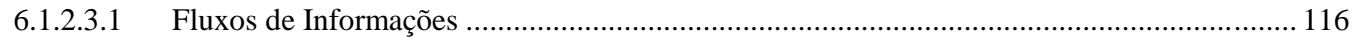

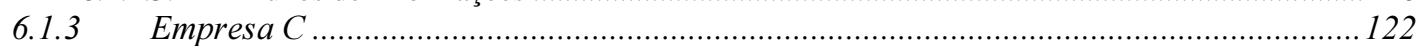

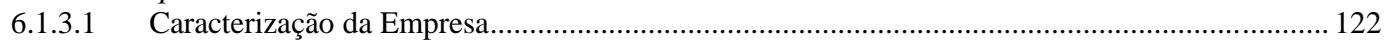

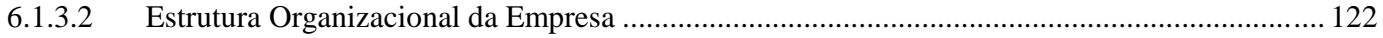

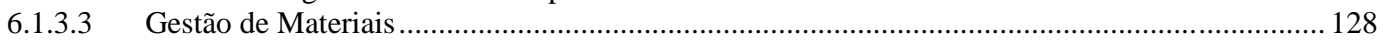

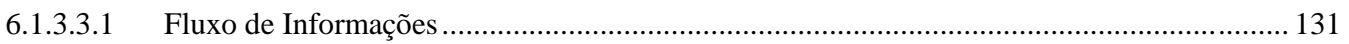

\section{CAPÍTULO 7 IDENTIFICAÇÃO DAS DIRETRIZES PARA A ELABORAÇÃO DO MODELO} DE GESTÃO DE FLUXO DE INFORMAÇÃO..............................................................................139

7.1 ANÁLISE DOS CASOS E IDENTIFICAÇÃo DAS DIRETRIZES ..................................................................139

7.1.1 Análise da estrutura dos fluxos de informações (parte fisica do sistema) ........................142

7.1.2 Análise das etapas pelas quais é processada a informação .......................................... 150

7.1.2.1 Identificação da necessidade .......................................................................................... 152

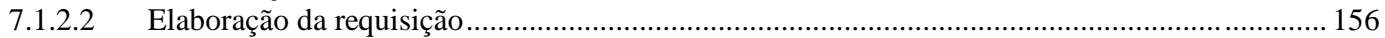

7.1.2.3 Teste de consistência e aprovação da requisição .................................................................... 161

7.1.2.4 Formulação da solicitação da cotação ............................................................................... 162

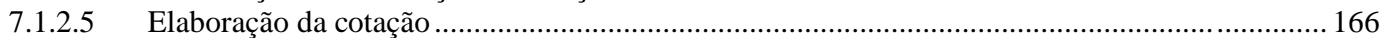

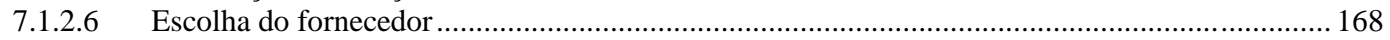

7.1.2.7 Compra e formulação do pedido de compra ........................................................................ 171

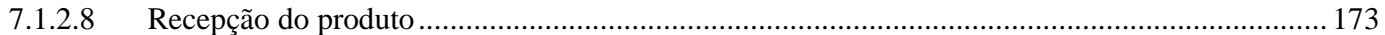

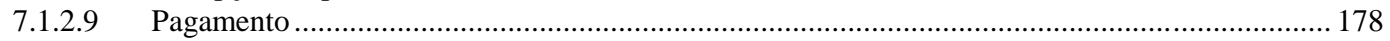

7.2 BuSCA DA MELHORIA CONTINUA E INOVAÇÃo DO SiSTEMA .................................................. 183

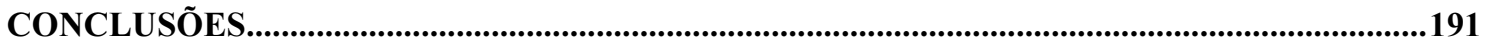

ANEXO.- QUESTIONÁRIOS EMPREGADOS NOS ESTUDOS DE CASO ..................................196

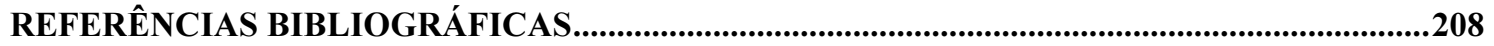




\section{Lista de Figuras}

FIGURA 1.- CADEIA DE SUPRIMENTOS (POIRIER; REITER, 1996 APUD LONDON ET AL.,1998)

FIGURA 2.- O PROCESSO DE COMUNICAÇÃO (SCHERMERHORN ET AL., 1994) …….................56

FIGURA 3.- GRAU NO QUAL O PROCESSO AS DECISÕES PODEM SER PROGRAMADO OU NÃO PROGRAMADO (BURCH ET AL., 1979)

FIGURA 4.- MATRIZ BENEFÍCIO / BENEFICIÁRIO (GIBSON; HAMMER APUD O'BRIEN; AL-

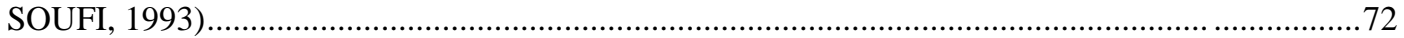

FIGURA 5.- PARALELO ENTRE INTERCÂMBIO DE INFORMAÇÕES DE NEGÓCIOS HUMANO/HUMANO E INTERCÂMBIO ELETRÔNICO SISTEMA/SISTEMA (FONTE

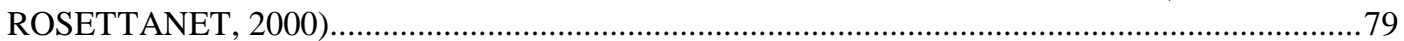

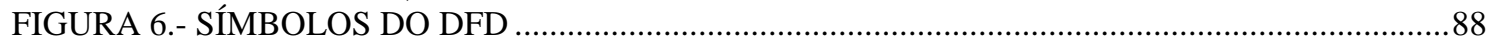

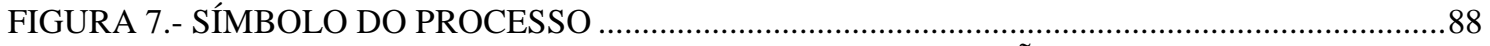

FIGURA 8.- ELEMENTOS DO PROCESSAMENTO DE INFORMAÇÕES ............................................92

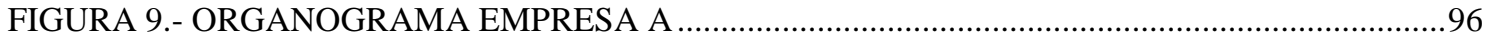

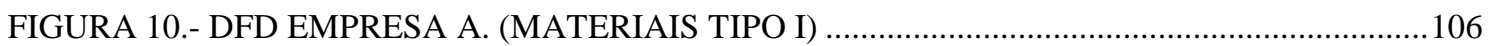

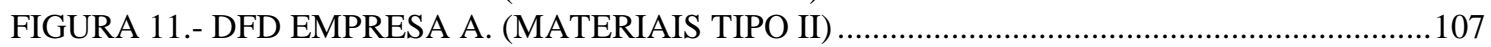

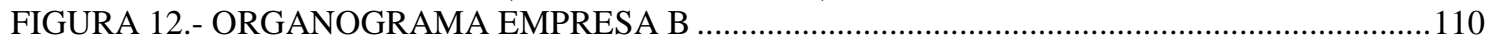

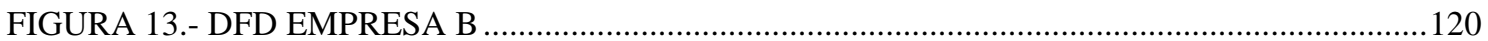

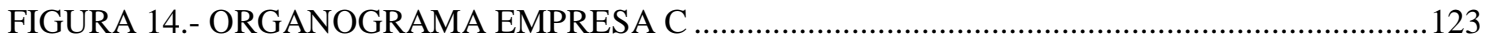

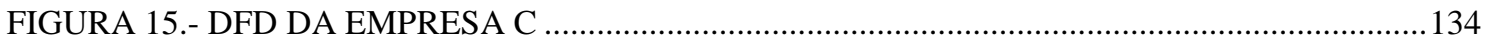

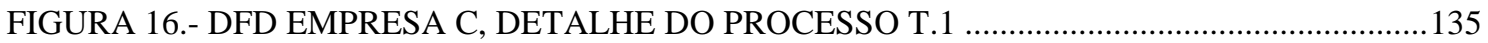

FIGURA 17.- DFD EMPRESA C, DETALHE DO PROCESSO T.2 …................................................136

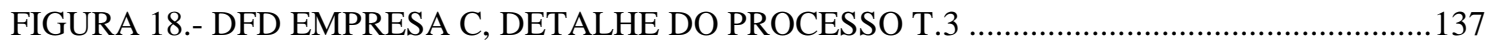

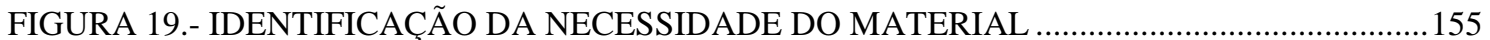

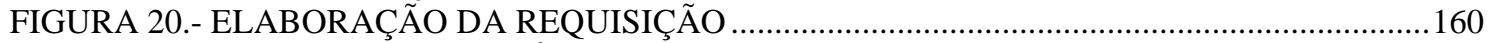

FIGURA 21.- TESTAR A CONSISTÊNCIA E APROVAR A REQUISIÇÃO .......................................162

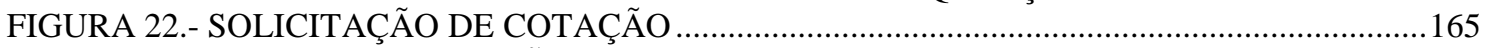

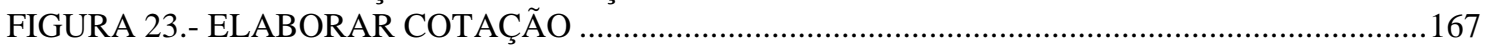

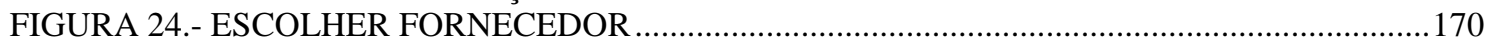

FIGURA 25.- COMPRAR E FORMULAR PEDIDO DE COMPRA ……........................................172

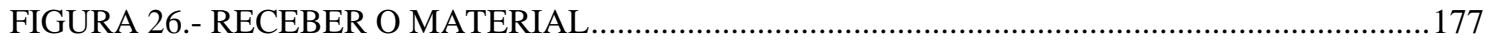

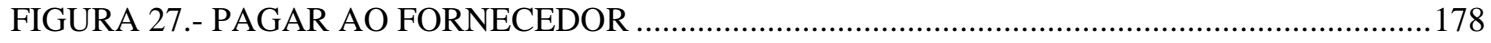

FIGURA 28.- DFD MODELO SEGUNDO OS CASOS ESTUDADOS ……......................................180

FIGURA 29.- DFD MODELO PARA A ELABORAÇÃO DO CRONOGRAMA SEMESTRAL DE

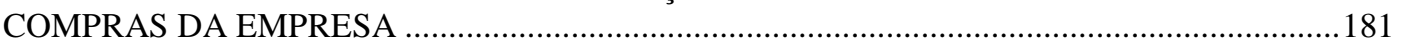




\section{Lista de Tabelas}

TABELA 1.- CARACTERIZAÇÃO DOS FORNECEDORES NO SETOR EDIFICAÇÕES.

TABELA 2.- CLASSIFICAÇÃO DAS EMPRESAS FORNECEDORAS SEGUNDO AS

CARACTERÍSTICAS DO PRODUTO FORNECIDO.

TABELA 3.- PORTE DA EMPRESA SEGUNDO O NÍVEL DE FUNCIONÁRIOS E A PROFISSIONALIZAÇÃO PARA EUA (BURTON; OBEL,1995)

TABELA 4.- ESTRUTURA ORGANIZACIONAL VERSUS CONDICIONANTES.

TABELA 5.- TABELA DE REQUISIÇÃO DE MATERIAIS PARA EMPRESA A

TABELA 6.- MATRIZ DE RESPONSABILIDADES (EMPRESA A)

TABELA 7.- DICIONÁRIO DE DADOS (EMPRESA A)

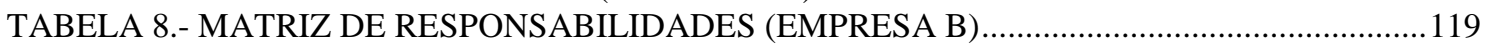

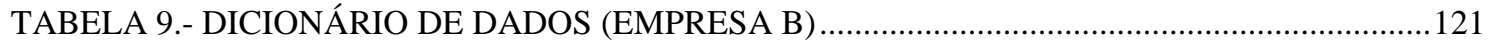

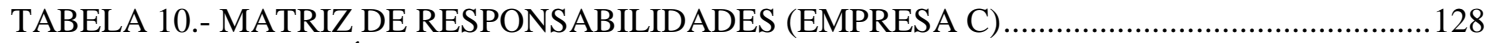

TABELA 11.- DICIONÁRIO DE DADOS (EMPRESA C) ...............................................................138

TABELA 12.- CAUSAS DOS PROBLEMAS NOS FLUXOS DE INFORMAÇÃO NAS EMPRESAS ESTUDADAS

TABELA 13.- RELAÇÃO DAS CAUSAS DOS PROBLEMAS IDENTIFICADOS COM A FORMA DOS FLUXOS DE INFORMAÇÃO OU COM A INFORMAÇÃO QUE POR ELES CIRCULA.

TABELA 14.- QUADRO COMPARATIVO DAS EMPRESAS A, B E C EM RELAÇÃO ÀS CARACTERÍSTICAS DE SUA ESTRUTURA ORGANIZACIONAL

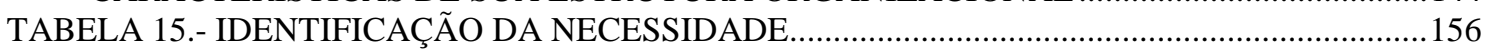

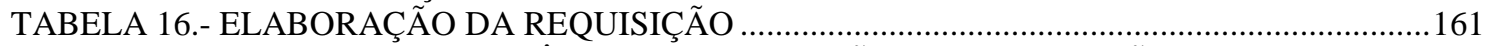

TABELA 17.- TESTE DA CONSISTÊNCIA E APROVAÇÃO DA REQUISIÇÃO ...............................162

TABELA 18.- FORMULAÇÃO DA SOLICITAÇÃO DA COTAÇÃO ………......................................166

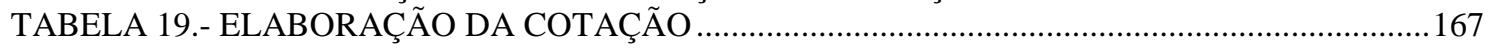

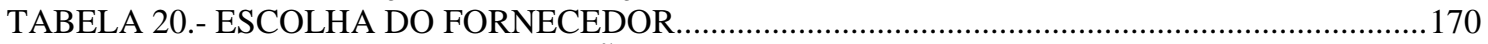

TABELA 21.- COMPRA E FORMULAÇÃO DO PEDIDO DE COMPRA …….................................172

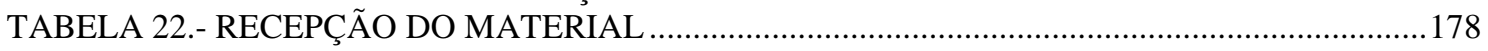

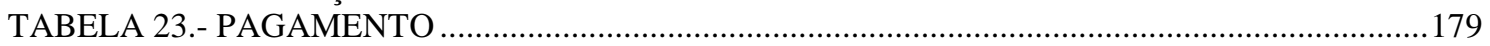

TABELA 24.- DICIONÁRIO DE DADOS PARA OS FLUXOS DO MODELO PROPOSTO ..............182 


\section{Lista de Abreviaturas}

\begin{tabular}{|c|c|}
\hline ABNT & Associação Brasileira de Normas Técnicas \\
\hline ANSI & American National Standard Institute \\
\hline BPM & Boletim de programação mensal de materiais (Empresas C) \\
\hline CDHU & $\begin{array}{l}\text { Companhia de Desenvolvimento Habitacional e Urbano do Estado de } \\
\text { São Paulo }\end{array}$ \\
\hline CLM & $\begin{array}{l}\text { Council of Logistics Management (Conselho de Gestão Logística, } \\
\text { entidade com sede nos Estados Unidos) }\end{array}$ \\
\hline COBRACON & Comitê Brasileiro de Construção Civil da ABNT (CB-02) \\
\hline CRSO & Cronograma de Suprimentos Semestral (Empresa C) \\
\hline $\mathrm{CSC}$ & Construction Specifications Canada \\
\hline CSI & Construction Specifications Institute \\
\hline DD & Dicionário de Dados \\
\hline DFD & Diagrama de Fluxo de Dados \\
\hline EDI & Electronic Data Interchange (Troca de Dados Informatizados) \\
\hline EPUSP & Escola Politécnica da Universidade de São Paulo \\
\hline ERP & Enterprise Resource Planning \\
\hline GDRM & Guia de Recebimento de Material (Empresa C) \\
\hline GO & Gerente de Obras (Empresa C) \\
\hline $\mathrm{JIT}$ & Just-in-Time (Sistema sincronizado de produção) \\
\hline $\begin{array}{l}\text { MRP ou } \\
\text { MRP I }\end{array}$ & $\begin{array}{l}\text { Materials Requirement Planning (Planejamento dos Requisitos de } \\
\text { Materiais) }\end{array}$ \\
\hline MRP II & $\begin{array}{l}\text { Manufacturing Resource Planning (Planejamento dos Recursos de } \\
\text { Manufatura) }\end{array}$ \\
\hline PBQP-H & Programa Brasileiro da Qualidade e Produtividade do Habitat \\
\hline PEF & Pedido Externo de Fornecimento (Empresa C) \\
\hline QUALIHAB & $\begin{array}{l}\text { Programa da Qualidade na Construção Habitacional do Estado de São } \\
\text { Paulo }\end{array}$ \\
\hline TI & Tecnologia da Informação \\
\hline TQM & Total Quality Management (Gestão Total da Qualidade) \\
\hline
\end{tabular}




\section{Resumo}

Este trabalho objetiva propor diretrizes para a elaboração de um modelo de gestão de fluxo de informações como suporte à logística em empresas construtoras de edifícios.

O foco da pesquisa limita-se especificamente à gestão de materiais, apesar da logística também abranger mão-de-obra, serviços e equipamentos. O objetivo da gestão de materiais é o de assegurar um fluxo continuo e sem interferências de materiais e componentes à obra, na quantidade requerida, com a qualidade especificada, no tempo e lugar certo, ao menor custo total.

Estas diretrizes foram identificadas visando a uma integração funcional dentro da empresa construtora. Com base em um estudo de caso realizado em três empresas construtoras e em um levantamento e estudo bibliográfico, foram estudados os fluxos de informações ligados à gestão de materiais que ocorrem dentro das empresas construtoras. Desta maneira, identificaram-se os principais fatores que facilitam e que dificultam os fluxos de informações entre agentes relacionados com a gestão de materiais. Uma vez analisados estes fatores, foram identificadas as diretrizes objeto desta pesquisa e foi proposto um fluxo de informações modelo baseado exclusivamente nos casos estudados.

Adicionalmente, foram discutidos alguns parâmetros a se levar em conta para avaliar o modelo proposto e conseguir uma melhoria continua dentro do processo. Também, foi brevemente discutida a forma como as parcerias com os fornecedores, o uso de produtos normalizados, a Internet e os códigos de barras poderiam inovar estes fluxos de informações e conseguir a integração tão almejada na cadeia de suprimentos. 


\begin{abstract}
This research aims to identify guidelines for developing an information flow management model to support materials management in building construction firms. The main purpose of building materials management is to have the required materials at the right place, at the right time, in the right quantity without prejudicing cost and quality.

These guidelines were identified considering a functional integration within the construction firm. Based on three case studies developed in construction firms and a literature review, the materials management information flows inside the construction firm were studied. In this way, the principal factors that affect or enhance these information flows were analyzed. Once analyzed these factors, we were able to determine the best arrange for these flows and identify the guidelines and propose an information flow model based exclusively in the three cases studied.

Besides this, we discussed the parameters that should be taken into account to guarantee a continuous improvement in the model proposed. Finally, we briefly discuss how partnering with suppliers, the use of normalized products, the Internet and the use of code bars could innovate traditional information flows and integrate the supply chain.
\end{abstract}




\section{Capítulo 1 Introdução}

\subsection{Justificativa}

Nesta época, a elevada competição setorial aparece como uma das principais razões pela qual as empresas que atuam no subsetor da construção de edifícios estão tendo que redefinir suas estratégias com a finalidade de sobreviver. CARDOSO (1996a) afirma que tais empresas construtoras terão que passar necessariamente pela melhoria de sua eficiência produtiva para poderem superar esta nova característica do setor; desta maneira, conseguiriam reduzir seus custos de produção e poderiam se manter no mercado, sendo mais competitivas.

Para atingir este novo objetivo, que se traduz por uma otimização dos recursos de produção - mão-de-obra, materiais e equipamentos -, as empresas podem optar por muitas formas de racionalizar seu processo produtivo, baseando-se sempre em um enfoque sistêmico.

CARDOSO (1996a) identifica oito formas genéricas de racionalização da produção de edifícios, sendo que em muitas delas considera a racionalização da logística como um elemento fundamental para a otimização do fluxo de recursos de produção. Este fluxo abrange desde a identificação da necessidade do recurso até a incorporação deste recurso no processo construtivo.

AGAPIOU et al. (1998b) afirmam que atualmente o conceito da logística constitui cada vez mais uma ferramenta gerencial de extrema importância, já que assegura uma perspectiva estratégica ao fluxo de materiais do processo produtivo. 
Estes autores destacam também que a gestão do fluxo de materiais dos fornecedores até o canteiro requer uma concepção e um controle cuidadosos dos fluxos de informação relativos aos produtos e aos processos de produção.

De igual forma, asseguram que sob a óptica da logística a gestão de informação é crucial porque os diferentes processos e operações acontecem normalmente de forma simultânea dentro do canteiro, o que faz com que lidar como essas informações seja uma dificuldade para as empresas.

STUKHART (1995) compartilha esta opinião e coloca a comunicação e o planejamento como funções vitais para uma gestão eficiente de materiais.

SILVA, CARDOSO (1998) afirmam que a racionalização da logística passa necessariamente pela racionalização dos fluxos de informações, e indicam algumas ações que podem ser tomadas para atingir este objetivo, quais sejam:

- criação de um sistema de informações logísticas: organização e formalização das formas de emissão, recebimento, e registro das informações;

- definição de um sistema de decisões;

- eliminação de ruídos nos fluxos de informação;

- aumento de velocidade de processamento e circulação das informações;

- eliminação de informações duplicadas.

AHMAD et al. (1995) reforçam a importância da comunicação dentro do setor e afirmam que, para a construção, o intercâmbio de informações é um aspecto essencial para o bom desenvolvimento do processo de produção e que o sucesso desta troca depende da acessibilidade e da qualidade dos dados, bem como da eficiência e da eficácia do sistema projetado para o processamento dos mesmos. 
Complementando esta afirmação, pode-se acrescentar que para conseguir fornecer um respaldo adequado a seus processos, as empresas devem possuir uma capacidade de processamento de informações maior ou igual à sua demanda por processamento.

Atualmente, a Tecnologia de Informação (TI), cada vez mais acessível ao público, está facilitando e propiciando a troca de informações e aumentando a capacidade de processamento de informações da empresa. O aparecimento da Internet, por exemplo, viabiliza novas formas de comunicação e de fazer negócios, como o comércio eletrônico, o aluguel de softwares para coordenação de projetos e para gestão, etc.

O uso destas novas tecnologias nas empresas está modificando a estrutura de seus fluxos de informação e portanto mudando sua estrutura organizacional. Nesse sentido, GALBRAITH (1974) explica que existe uma relação entre os fluxos de informação e a estrutura organizacional das empresas. Sendo que uma empresa processa informações para coordenar e controlar suas atividades, a estrutura organizacional é quem geralmente determina os fluxos de informação; porém, uma mudança nos fluxos de informação pode fazer com que a estrutura organizacional da empresa mude. É interessante ressaltar este último comentário pois implica que a partir da intervenção nos fluxos de informações pode-se conseguir uma mudança na estrutura organizacional da empresa.

Por outro lado, não se deve esquecer que a logística envolve agentes internos e externos (fornecedores) à empresa e portanto é importante também entender o modo como estes agentes externos intervêm na logística da empresa construtora para poder identificar as possíveis oportunidades de melhoria desta atividade.

Autores como AGAPIOU et al. (1998a) e (1998b) apresentam estudos de casos baseados em parcerias com fornecedores para desenvolver sistemas de logística que 
otimizem o processo de produção. AKINTOYE (1995) estuda a aplicação do JIT “Just-in-Time” para a gestão de materiais na construção civil, a qual não é possível sem o apoio dos fornecedores. Na França, alguns trabalhos como o descrito por AIELLO et al. (1997) estão baseados na idéia do planejamento logístico como meio de melhoria do desempenho do processo produtivo.

Os estudos anteriormente citados demostram que aspectos tais como o envolvimento ativo dos fornecedores no processo de produção, desde a etapa de concepção do projeto, adquirem cada vez mais importância para a sua eficiência.

Em resumo, não se pode pensar em um sistema logístico racionalizado sem considerar todos os agentes que intervêm nesse processo e sem fazer com que estes tenham acesso a canais eficazes de comunicação, que permitam com que a informação circule de uma forma contínua, com qualidade. O impacto das novas tecnologias da informação no interior das empresas é também um outro aspecto importante a se levar em conta já que elas facilitam a troca de informações e aumentam a capacidade de processamento de informações dentro das empresas.

Assim sendo, adota-se aqui a conceituação de logística definida pelo Council of Logistics Management, CLM (2000), por ser a que se considerou a mais apropriada para a construção civil, qual seja, " a parte do processo de gestão da cadeia de suprimentos, que trata do planejamento, implementação e controle eficiente e eficaz do fluxo e armazenagem de bens, serviços e informações relacionados, do seu ponto de origem até o seu ponto de consumo, de maneira a satisfazer plenamente às necessidades dos clientes".

No Brasil, a importância da logística já é percebida por algumas empresas construtoras. O fato das empresas começarem a se preocupar em procurar formas para diminuir suas 
perdas e de aumentar sua produtividade denotam este interesse. Além disso, este novo fator tem favorecido a formação de empresas que têm como função principal dar assessoria técnica nessa área.

Por outro lado, no ambiente acadêmico está começando a existir uma preocupação sobre o tema. Por exemplo, GUERRINI (1997) apresenta um Sistema de Administração da Produção que tem como objetivo planejar e controlar os diferentes processos de produção; além desta pesquisa, destaca-se também os seguintes trabalhos: CARVALHO et al. (1998), $\quad$ BERNARDES (1996), $\quad$ SANTOS (1995), PALACIOS (1994), entre outros. No entanto, ainda existem poucos trabalhos e publicações que enfoquem a importância da racionalização da logística como um meio eficaz para atingir a eficiência no processo de produção de edifícios.

Identificando esta necessidade, o Departamento Engenharia de Construção Civil da Escola Politécnica da USP tem alguns trabalhos desenvolvidos ou em andamento relacionados com o tema da logística. Um destes trabalhos é o de Fred Borges da Silva, o qual apresenta um análise do papel da logística no sistema de produção de edifícios. Tal trabalho estuda principalmente os fluxos de recursos dentro das empresas e seus canteiros (SILVA, 2000a).

A idéia desta nova pesquisa ora descrita foi a de propor diretrizes que norteiem a elaboração de um modelo de gestão de fluxo de informação como uma ferramenta de suporte ao sistema logístico de uma empresa construtora de edifícios, com foco na gestão de materiais. Ela supõe o uso da Tecnologia de Informação - TI, que englobam as tecnologias aplicadas a processar, guardar e transmitir informações eletronicamente (LUCAS, 1997). A TI tem se tornado uma ferramenta cada vez mais acessível às 
empresas e, a partir da modificação dos fluxos de informações que ocorrem no seu interior, está mudando também as suas próprias estruturas organizacionais.

\subsection{Objetivos}

\subsubsection{Objetivo Principal}

Dentro deste contexto, esta pesquisa objetiva propor diretrizes para a elaboração de um modelo de gestão de fluxo de informações como suporte à logística de uma empresa construtora de edificações. Em virtude das limitações de tempo e tendo em vista o âmbito de uma dissertação de mestrado, o foco da pesquisa limita-se especificamente à gestão de materiais. Sendo o objetivo da gestão de materiais o de assegurar um fluxo continuo e sem interferências de materiais à obra, na quantidade requerida, com a qualidade especificada, no tempo e lugar certo, ao menor custo total.

Estas diretrizes serão identificadas visando a uma integração funcional dentro da empresa construtora (obras, departamentos) e também a uma integração entre a empresa construtora e seus fornecedores. Levar-se-á em conta que, cada vez mais, essa integração se dá com elementos externos como a Internet.

\subsubsection{Objetivos Secundários}

Os objetivos específicos são:

- identificar as características dos fluxos de informações das atividades relativas à gestão de materiais em empresas construtoras de edifícios;

- identificar os motivos das possíveis interferências ou ruídos nos fluxos de informações relativos à gestão de materiais que ocorrem no interior das empresas construtoras (obras, departamentos); 
- levantar e analisar a bibliografia existente sobre sistemas de informação, verificando seus principais conceitos e ferramentas e discutir sua importância na construção de edifícios;

- identificar as possíveis tecnologias de informação que possam ser usadas para otimizar o fluxo de informações logísticas;

- identificar possíveis formas de racionalização dos fluxos de informações relativos à gestão de materiais em empresas construtoras.

\subsection{Metodologia}

A metodologia de pesquisa constou de três etapas principais: levantamento e revisão bibliográfica; pesquisa de campo; identificação das diretrizes para a elaboração de um modelo de gestão de fluxo de informações como suporte à logística de uma empresa construtora de edificações.

A primeira etapa constitui-se em uma pesquisa e em uma revisão bibliográfica, fornecendo elementos que serviram como base conceitual e instrumental para as etapas seguintes. Os temas abordados nesta pesquisa bibliográfica foram: conceitos da logística na indústria seriada; logística na construção civil; gestão de materiais; gestão de projetos; gestão de produção; cadeia de suprimentos; importância da informação e comunicação na organização; tecnologia da informação.

Esta pesquisa bibliográfica cobriu livros, teses, dissertações e artigos de revistas internacionais e nacionais de interesse. A idéia foi a de se conseguir um respaldo intelectual que consolidasse conceitos e descortinasse novos enfoques sobre o tema.

Esta etapa serviu igualmente para identificar conceitos importantes que deveriam ser tratados na pesquisa de campo assim como para formular com base neles um método 
para a análise dos fluxos de informações relativas à gestão de materiais em empresas construtoras.

A segunda etapa constitui-se de uma pesquisa de campo dentro das empresas construtoras. AVENIR (1989) afirma que o estudo de caso é um método de pesquisa no campo das ciências sociais que pode ter como objetivos: descobrir novos problemas; sugerir hipóteses; entender um fenômeno ou verificar hipóteses previamente estabelecidas. Neste trabalho, os estudos de caso realizados tiveram caráter exploratório, a idéia principal nesta etapa foi a de entender os fluxos de informação que ocorrem tanto no seio das empresas construtoras quanto nas relações existentes entre tais agentes e seus fornecedores.

Para a seleção das empresas construtoras decidiu-se que estas deveriam ter uma postura inovadora frente ao uso da tecnologia da informação, para que proporcionassem uma visão das melhores praticas existentes no mercado. Sendo assim, escolheram-se três empresas construtoras, aqui identificadas pelas letras A, B e C. Estas empresas foram também escolhidas devido às relações que mantêm com a Escola Politécnica da USP. Todas elas apresentaram boa disposição para o desenvolvimento da pesquisa.

Para a coleta de dados e o mapeamento dos fluxos de informação dentro destas empresas optou-se por entrevistas com questionários semi-abertos, observações diretas feitas nas empresas e análise de documentos. Todas estas ferramentas são recomendadas por diversos autores para a coleta de informações em estudos de caso (AVENIR, 1989; BARTON et al., 1985).

O motivo de se fazer um questionário semi-aberto foi porque este daria flexibilidade à entrevista e permitiria a coleta de outras informações que, apesar de não estarem no 
questionário, seriam úteis para estruturar os fluxos de informação relativos à gestão de materiais.

Conseguiu-se gravar todas as entrevistas realizadas com o consentimento dos entrevistados, o que resultou em uma vantagem já que as fitas constituíam uma base de dados que foi consultada cada vez que existiu alguma dúvida acerca das entrevistas.

Decidiu-se que as entrevistas em cada empresa construtora seriam pelo menos três:

- uma primeira entrevista com um membro da diretoria da empresa. O objetivo desta entrevista foi caracterizar a empresa: origem, porte, tecnologia, recursos, estratégias, estrutura organizacional, etc.

- Uma segunda entrevista, com o responsável da área de suprimentos da empresa. Já esta entrevista entrou no foco da pesquisa, e o seu objetivo foi mapear os fluxos de informação que se dão desde que o pedido chega no escritório central e volta para a obra sob a forma de uma compra. Em algumas empresas, não somente se entrevistou o responsável pela área de suprimentos, como também os responsáveis por áreas afins, como: planejamento, orçamentos, controle de custos, etc. Outro ponto importante nesta etapa também foi o levantamento dos sistemas informatizados que serviam de suporte para estes fluxos de informação.

- A terceira entrevista foi dirigida para o engenheiro de obras. Como no caso anterior, esta procurava mapear os fluxos de informações que acontecem nas obras, relativos à gestão de materiais, mas neste caso no interior do canteiro.

Os questionários foram estruturados tendo como referência o tipo de entrevista em que seriam utilizados (ver Anexo).

Depois de elaborados os questionários procedeu-se às entrevistas nas empresas e aplicou-se os questionários semi-abertos. Como já foi comentado, as entrevistas 
puderam ser gravadas e os questionários serviram como guia e estabeleceram uma sequiência nas entrevistas. Normalmente, os questionários não foram preenchidos no momento da entrevista. A transcrição dos dados deu-se no laboratório da Escola Politécnica da USP- EPUSP, a idéia tendo sido a de se transcrever a entrevista feita e paralelamente se preencher os questionários.

Com os dados coletados procedeu-se à caracterização e ao entendimento do fluxo de informações logísticas dentro da empresa construtora (obras e departamentos), com base nas ferramentas obtidas na pesquisa bibliográfica (ver Capítulo 5). A análise destes dados também foi feita em base no método proposto nesse capítulo.

Pretendeu-se com esta análise identificar as principais virtudes e problemas nos fluxos de informação das empresas. A idéia foi a de se encontrar as principais causas que condicionam tais características e identificar os contextos gerenciais que as potencializam. Finalmente, com base nesta análise, formulou-se as diretrizes que norteiem a elaboração dos modelos de gestão de informações nas empresas construtoras.

\subsection{Estrutura do Trabalho}

O trabalho está estruturado em oito capítulos, além de um anexo e das referências bibliográficas. Neste primeiro capítulo foram apresentadas as justificativas para a escolha do tema da pesquisa e os objetivos que se pretende alcançar com o trabalho.

O segundo capítulo discute os principais conceitos relacionados com a logística, quais sejam: evolução da logística, logística de canteiro, logística de suprimentos, gestão de materiais, gestão de qualidade, Just-in-Time e cadeia de suprimentos. O capítulo serve fundamentalmente como embasamento conceitual para o desenvolvimento do método de análise dos fluxos informações proposto no quinto capítulo. 
O terceiro capítulo também é um capítulo teórico no qual discute-se a importância da informação dentro da organização. Para tal apresentam-se as características das estruturas organizacionais e discute-se a forma como estas se vêem influenciadas por fatores externos e internos à empresa, como são a estratégia, ambiente, tecnologia e porte. Os conceitos discutidos neste capítulo também foram utilizados para a formulação do quinto capítulo.

No quarto capítulo se faz uma breve referência sobre as tecnologias da informação e como estas vêm sendo utilizadas nas empresas construtoras de edifícios e o potencial que elas podem ter na racionalização dos fluxos de informações.

Já o quinto capítulo consolida os conceitos discutidos nos capítulos anteriores. Formula assim um método para analisar os fluxos de informações em empresas construtoras, que é empregado para análise dos estudos de caso.

No sexto capítulo, apresentam-se os dados coletados nas empresas construtoras estudadas.

Já no sétimo capítulo, analisa-se os dados coletados nas empresas e identifica-se, a partir desta análise, as principais diretrizes para a elaboração do modelo de gestão de fluxos de informações. Para a análise dos dados utiliza-se o método proposto no capítulo 5.

Além disso, discute-se os parâmetros que deverão se levar em consideração para garantir uma melhoria contínua no modelo proposto, e a forma como este modelo poderia ser inovado através da consolidação de parcerias com os fornecedores e do uso de produtos normalizados, da Internet e dos códigos de barras.

Por ultimo, no capitulo final colocam-se as principais conclusões deste trabalho. 


\section{Capítulo 2 Logística}

Como este trabalho objetiva propor diretrizes para a elaboração de um modelo de gestão de informações como suporte à gestão de materiais em empresas construtoras, considera-se importante começar por definir a logística e a sua evolução na indústria seriada. Entende-se que este é um conceito mais abrangente, que se constitui na base para abordar o tema da gestão de materiais. Segue-se com a logística na construção civil, para chegar-se finalmente ao papel da gestão de materiais na construção de edifícios.

Dentro deste último tema discute-se a sua relação com a gestão de projetos, gestão da produção das empresas e com a cadeia de suprimentos.

\subsection{Definição e evolução do termo}

A logística é um termo que tem evoluído e adquirido muita importância durante o transcurso do século XX. A literatura indica que este termo foi inicialmente ligado às operações militares. Uma versão de sua origem é que a palavra logística deriva do termo francês "logistique", o qual era o título utilizado pelo oficial da armada de Napoleão responsável pelo alojamento das tropas e pela comida para os cavalos (LA LONDE, 1994). Durante a Segunda Guerra Mundial os militares fizeram uso eficaz de modelos logísticos para assegurar que as pessoas, materiais, máquinas, etc. estivessem no lugar certo quando necessitados. Atualmente, o termo continua sendo amplamente utilizado para aplicações militares.

No entanto, foi somente na década de 50 que a logística começou a adquirir importância na manufatura. Na época, o termo freqüentemente usado era o de "redes de distribuição 
física ${ }^{1}$. No fim da década de 50, a recessão criou um ambiente no qual as empresas começaram a procurar sistemas eficazes de controle de custos. Como conseqüência as empresas perceberam que a logística era uma atividade cujo custo ainda não tinha sido devidamente estudado nem coordenado (JOHNSON; WOOD, 1996).

Outros fatores que contribuíram para o surgimento da logística na indústria manufatureira foram: o incremento no custo do transporte e dos estoques; a mudança da forma da gestão dos inventários; a proliferação das linhas de produção; o incremento no uso da tecnologias de informação por parte das empresas e seus fornecedores; entre outros.

Para explicar a evolução da logística vários autores a dividem por períodos (BOWERSOX et al., 1986, MASTERS; POHLEN, 1994). Por ser mais atualizada, utiliza-se a divisão feita por MASTERS; POHLEN (1994). Esta consta de três períodos, que são apresentados a seguir.

\subsubsection{Período de gestão funcional (fim da década de 50 até a década de 70)}

MASTERS; POHLEN (1994) asseguram que este período caracterizou-se por ser uma época na qual as empresas passaram gradualmente de uma de gestão fragmentada de processos individuais (transporte, compras, armazenagem) a uma gestão integrada de funções relacionadas. As duas grandes áreas que agruparam estes processos foram a gestão de materiais e a distribuição física.

A gestão de materiais encarregava-se basicamente do fluxo de materiais dentro da empresa, o qual incluía principalmente os processos de compra, matérias primas, controle de estoques, planejamento da produção, etc. Enquanto que a distribuição fisica,

\footnotetext{
${ }^{1}$ LA LONDE (1994) relata que em 1948 a Associação Americana de Marketing definiu distribuição física como o "movimento e manuseio de bens desde o ponto de produção até o ponto de consumo ou uso".
} 
tinha como função principal o fluxo eficiente de produtos terminados desde o final da produção até o consumidor (MASTERS; POHLEN, 1994).

Os anos entre 1956 e 1965 caracterizaram-se por ser um período de conceituação. Foram nestes anos que o conceito da logística integrada começou a se cristalizar. Como os principais fatores motivadores desta conceituação BOWERSOX et al. (1986) indicam: o desenvolvimento de uma análise de custo total integrada; a aplicação do enfoque sistêmico; o incremento da importância do serviço ao consumidor, entre outros.

Os seguintes cinco anos (1966 - 1970) foram uma época onde os conceitos básicos da logística foram avaliados. O resultado global foi que o custo e o beneficio suposto transformou-se em realidade. Os programas de gestão passaram a focalizar seu interesse na melhoria operacional e paralelamente um grande número de empresas começou a implementar os conceitos da logística (BOWERSOX et al., 1986).

Já a década que se seguiu (1971 - 1979) foi uma época de mudança de prioridades. Apareceu uma grande preocupação mundial devido à falta de disponibilidade de energia a baixo custo. Os preços e a escassez dos combustíveis resultaram em uma escassez de vários produtos básicos para a indústria manufatureira. Sendo que o transporte e a estocagem encontravam-se entre os maiores consumidores de energia, a logística teve que enfrentar a necessidade de otimizar os seus usos. Por outro lado, enquanto que em décadas anteriores a prioridade da logística esteve focada na distribuição física, nesta época a gestão de materiais passou ser o centro de atenção devido à necessidade de trabalhar com recursos escassos. Paralelamente, os métodos tradicionais de busca de materiais mudaram, começou-se a adotar o "Just-in-Time" e a aquisição de materiais mudou de reativa a pró-ativa. Em vez do planejamento de operações ser feito em função 
das necessidades do marketing, a gestão focou sua atenção em formas para dar continuidade à produção, apesar da escassez de recursos (BOWERSOX et al., 1986).

\subsubsection{Período de Integração Interna (década de 80)}

Neste período surgiu a necessidade de se conseguir no interior das organizações uma gestão total dos fluxos. A logística integrada aparece como um termo que define esta integração.

SHARMAN (1984) ${ }^{2}$ apud MASTERS; POHLEN (1994) definiu a logística integrada como "o conjunto das atividades relativas à movimentação de materiais, incluindo sistemas de informação e sistemas de controle; a logística constitui uma cadeia que passa por todas as responsabilidades funcionais tradicionais desde a identificação das matérias primas até a entrega do produto”. Este novo enfoque abrange tanto a área de distribuição física quanto a área de gestão de materiais.

Complementando esta definição o "Council of Logistics Management", CLM, definiu em 1985 a logística como "o processo de planejar, implementar e controlar o fluxo e o armazenamento eficaz de matérias primas, inventário, bens, serviços e informações relacionados desde o ponto de origem até o ponto de consumo com a finalidade de satisfazer às exigências do cliente”. Note-se que esta definição é mais abrangente que a anterior e que inclui não somente os materiais mas também os serviços.

A nova organização estrutural que promovia a logística integrada trouxe consigo vários benefícios para as empresas que a implementaram, quais sejam: vantagem competitiva através de custos menores, favoreceu as relações cliente \& fornecedor e agregou valor à cadeia de suprimentos (MASTERS; POHLEN, 1994).

2 SHARMAN, G. The rediscovery of logistics. Harvard Business Review, (September-October 1984):72. 
Os condicionantes mais significativos que nessa época favoreceram a implantação da logística integrada foram: a revolução das tecnologias de informação e comunicação, a mudança na política reguladora de transportes (EUA) e a necessidade de se dar ao cliente um serviço cada vez melhor.

\subsubsection{Período de Integração Externa (década de 90)}

A década de noventa apareceu como um período onde já não era suficiente a integração da empresa como um todo. O conceito da cadeia de suprimentos estende este conceito de integração funcional a todas as empresas da cadeia de produção do material ou produto: da matéria prima, ao posto de consumo, passando pelos distribuidores, transportadores, produtores, etc.

Unindo-se a este novo enfoque, o Council of Logistics Management, CLM (2000), modificou levemente seu conceito de logística e, como já visto, a definiu como "a parte do processo de gestão da cadeia de suprimentos, que trata do planejamento, implementação e controle eficiente e eficaz do fluxo e armazenagem de bens, serviços e informações relacionadas, do seu ponto de origem até o seu ponto de consumo, de maneira a satisfazer plenamente às necessidades dos clientes".

Segundo MASTERS; POHLEN (1994), o principal motivo pelo qual as empresas estão adotando este novo enfoque é devido às vantagens potenciais que ele proporciona, quais sejam:

- redução de custos: adotar o conceito da cadeia de suprimentos permite às empresas um entendimento do comportamento dos custos e das possíveis fontes de diferenciação. Geralmente, os canais dos fornecedores e os distribuidores têm margens em seus benefícios as quais serão pagas pelo consumidor final. É 
importante que a empresa identifique essas margens já que a otimização delas pode servir como uma fonte de redução de custos.

- Redução de riscos.

- Otimização de recursos.

Em resumo, durante os últimos cinqüenta anos, o conceito da logística na indústria seriada passou de uma visão de gestão fragmentada a um enfoque que integra não somente as áreas no interior da empresa mas também todas as empresas da cadeia de suprimentos. Esta evolução foi o resultado de vários fatores mas os principais condutores desta transformação foram: a busca por parte das empresas de uma vantagem competitiva através da liderança em custo baseada na logística e o aparecimento e a acessibilidade crescente das novas tecnologias da informação.

É interessante notar o efeito da análise sistêmica dentro da evolução da logística. Através deste novo enfoque foi se entendendo que para otimizar o processo não bastava otimizar suas partes, mas era necessário se compreender o processo como um todo. $\mathrm{O}$ conceito de custo total integrado foi resultado desta nova visão.

Diferentemente da análise de custo tradicional, onde as decisões para a compra de um produto baseiam-se no preço deste sem considerar os custos indiretos envolvidos, o conceito de custo total integrado já leva em conta outros tipos de custos que podem significar em um custo adicional quando o processo é analisado globalmente. Assim, tem-se que o custo total é resultado de uma combinação dos seguintes custos (SILVA, 2000a):

- Custo de transporte $(\mathrm{Ct})$ : envolve custo de transporte externo.

- Custo de armazenagem e movimentação interna (Ca): envolve o custo das instalações das áreas para armazenagem ou processamento de componentes, 
equipamentos de movimentação e de segurança e de pessoal encarregado da movimentação e segurança.

- Custo de estoque (Ce): envolve o custo de oportunidade, custo com seguros, custo dos riscos de estocagem e custo por espaço.

- Custo de processamento de pedidos (Cp): envolve o custo administrativo para operacionalizar o processo de aquisição e distribuição, bem como o custo da informação para processá-las.

$$
\text { Custo Total }=C \text { produto }+C t+C a+C e+C p
$$

Sendo assim, ao analisar o custo de um produto deve-se tratar de otimizar este resultado e não os custos pontuais. Deve-se levar em conta que cada produto vem com um custo associado de transporte, armazenagem e estoque e que para cada caso deverá se fazer uma análise para poder decidir a situação economicamente mais favorável.

\subsection{A logística na Construção Civil}

Embora a evolução histórica anteriormente apresentada aborde especificamente a logística na indústria manufatureira, considerou-se importante entender o que acontece nessa indústria, pois a maioria dos modelos de gestão e logística aplicados à indústria da construção civil estão baseados em modelos que já foram utilizados na industria seriada. A evolução histórica serve para entender o contexto no qual as mudanças se deram e as razões que levaram a esses novos enfoques.

No subsetor edificações da construção civil, o termo é praticamente novo e a maioria das empresas encontra-se ainda em um estágio de evolução muito precário em comparação aos avanços da industria seriada. Diversos autores (AGAPIOU et al., 1998a; BERTELSEN, 1995; KOSKELA, 1992, SILVA, 2000a) 
afirmam que a maioria das perdas $^{3}$ na construção civil está fortemente ligada a uma gestão logística pouco desenvolvida e à falta de atenção por parte das empresas nesta área.

BERTELSEN (1995), por exemplo, destaca que vários estudos realizados na Suécia na área gestão de materiais demostraram que os baixos índices de produtividade encontravam-se fortemente relacionados a uma gestão logística deficiente. Identificou, assim, nove sintomas desta deficiência, quais sejam: (i) transporte interno de materiais excessivo; (ii) estocagem no canteiro de obras; (iii) grandes perdas; (iv) furtos; (v) falta de material; (vi) erros nas entregas; (vii) grande quantidade de materiais devolvidos ao fornecedor, (viii) quebras; (ix) danos em trabalhos já realizados. Além disso, os estudos mostraram que em média um operário passa aproximadamente um terço do seu tempo na obra procurando e manuseando materiais.

BERTELSEN; NIELSEN (1997) afirmam que nas empresas construtoras freqüentemente observa-se que não existe planejamento algum para a logística no processo construtivo, ainda mais, na maioria dos casos, o planejamento da produção não é confiável ou não existe. Segundo eles, em muitos casos, os pedidos e as entregas de materiais são realizados quando a produção fica parada devido à falta de material na obra. Adicionalmente, as compras geralmente são feitas com base no preço mais baixo, sem levar em conta fatores como qualidade, pontualidade, etc.

Estes mesmos autores também mencionam que, sendo a entrega de materiais raramente planejada, cada entrega passa a ser um elemento imprevisível que se agrega à “desordem geral". Tudo isso gera como resultado interrupções no trabalho, manuseios

\footnotetext{
${ }^{3}$ Entendendo-se por perdas como a diferença entre a quantidade de recurso prevista no projeto idealizado e a quantidade efetivamente utilizada (SIMPÓSIO NACIONAL DESPERDICIO DE MATERIAIS NOS CANTEIROS DE OBRAS, 1999).
} 
desnecessários de materiais, materiais não identificados no canteiro, perdas por quebras e furtos, além de demandar uma capacidade extra de estocagem.

Apesar de que estes estudos foram realizados na Suécia, pode-se afirmar que os sintomas são similares aos apresentados em canteiros de obras no Brasil (SILVA, 2000a; $\quad$ HAGA; SACOMANO, 1999; $\quad$ SACOMANO; GUERRINI, 1998; SIQUEIRA, 1998; HEINECK et al.,1995; SANTOS, 1995). Sendo que no setor edificações Brasileiro, as condições de competitividade e de sobrevivência têm mudado bastante na última década, as empresas construtoras estão tendo que redefinir suas estratégias de produção para reduzir suas perdas visando garantir sua permanência no mercado.

Neste sentido, HAGA; SACOMANO (1999) afirmam que a gestão da rede de suprimentos pode ser considerada uma vantagem competitiva já que o seu gerenciamento eficaz contribui para a diminuição das perdas de produtividade e também traz consigo melhorias de qualidade no setor de construção. Verifica-se desta forma a validade e a importância deste tema para o setor de edificações no Brasil.

Por outro lado, fazendo um paralelo com a divisão da logística na indústria manufatureira, observa-se que enquanto a logística na indústria seriada tem três focos principais: logística de abastecimento (externa), logística de manufatura (interna) e logística de distribuição (GURGEL, 1996), nas empresas construtoras do subsetor edificações esta se reduz a duas divisões principais que integram as diversas áreas logísticas nas empresas construtoras (CARDOSO, 1996b):

- logística de suprimentos (externa): que se encarrega dos fluxos de bens e serviços desde a identificação do material, compras e distribuição dos materiais ou serviços às obras. Além de outros aspectos relacionados, como: a seleção dos fornecedores, o 
desenvolvimento de boas relações ou parecerias com fornecedores e a gestão logística ligada à mão-de-obra (alojamentos, refeições, transporte).

- Logística de canteiro (interna): que se encarrega principalmente dos fluxos físicos dentro da obra, garantindo a disponibilização dos recursos nas frentes de trabalho. Esta subdivisão também inclui a gestão de interfaces entre atores e serviços, mecanismos de seleção de subempreiteiros, domínio dos equipamentos de transporte e segurança e o estabelecimento de projeto de higiene e segurança do trabalho.

É essencial ter clara esta distinção, já que a logística de distribuição na indústria seriada representa um custo significativo no processo, enquanto nas empresas construtoras a melhoria da logística deve ser focalizada na otimização da logística de suprimentos e da logística de canteiro.

Quanto à definição da logística para a industria da construção pode se considerar válida e apropriada a definição proposta pelo Council of Logistics Management (CLM), por ser a mais abrangente. Esta considera tanto os bens quanto os serviços e informações. Já as outras definições encontradas na literatura reduzem o escopo da logística aos recursos materiais e equipamentos sem levar em conta o fator mão-de-obra. Uma possível explicação para tal fato é que seus autores estão assumindo a mão-de-obra como própria da empresa. No entanto, no caso das empresas construtoras, atualmente existe uma tendência crescente por contratar serviços que incluam a mão-de-obra ou por subempreitar este recurso. Assim, a logística nestas empresas também deve se encarregar de colocar este recurso ou serviço no canteiro de obras.

A gestão de materiais para este tipo de empresas resulta assim como a parte da logística de suprimentos e de canteiro restrita especificamente aos recursos materiais e 
componentes. A seguir detalha-se as principais funções da gestão de materiais para o setor edificações da indústria da construção civil, por ser o tema deste trabalho.

\subsection{Gestão de Materiais}

STUKHART (1995) refere-se à gestão de materiais como um sistema de gestão integrada para controlar, planejar e redirecionar esforços com o intuito de executar as seguintes funções:

- quantificação de materiais;

- elaboração de especificações;

- preparação de requisições com documentos de suporte que definam os materiais do projeto;

- qualificação e seleção de fornecedores;

- $\quad$ solicitação de cotações;

- avaliação e aprovação de cotações, negociação, formulação de pedidos ou de contratos;

- entrega aos fornecedores da informação necessária (especificações, plantas, planejamento, datas de entrega, etc.) para assegurar a entrega segundo cronograma;

- controle de qualidade para assegurar atendimento às especificações;

- recebimento, inspeção, armazenagem e distribuição de materiais no canteiro;

- pagamento.

Essa definição é mais ampla do que a já vista de MASTERS; POHLEN (1994) já que combina aspectos das logísticas de suprimentos e de canteiro. Assim, utilizando os conceitos logísticos anteriormente apresentados, conclui-se que o objetivo da gestão de materiais é assegurar um fluxo continuo e sem interferências de materiais à obra, na 
quantidade requerida, com a qualidade especificada, no tempo e lugar certo, ao menor custo total.

Como pode-se perceber, a gestão de materiais envolve participantes externos e internos à empresa construtora. Dentro da empresa, as principais áreas e departamentos envolvidos são os seguintes: obras, orçamentos, suprimentos, planejamento, contas a pagar, etc. Já os agentes externos à empresa que participam neste processo são principalmente os fornecedores de materiais, mas também os projetistas, ao definirem as especificações dos materiais.

Portanto, o bom andamento deste processo depende fortemente do compartilhamento e da troca de informações entre estes agentes, sejam externos ou internos à empresa construtora. Sendo assim, tanto a integração entre departamentos quanto a integração entre empresa construtora \& fornecedores torna-se um requisito indispensável para a boa gestão de materiais.

Atualmente, a tecnologia da informação (veja definição no Capítulo 4) apresenta-se como um caminho para atingir esta integração, já que dia a dia ela se faz mais acessível às empresas em geral. A aparição de sistemas informatizados facilita o compartilhamento das informações comuns entre os diversos departamentos que suportam a logística e entre a construtora e seus fornecedores.

Em resumo, sendo o objetivo essencial da gestão de materiais o de dar respaldo à produção para que ela não pare por falta de material, e levando em conta que este recurso é determinado inicialmente no projeto e posteriormente fornecido por agentes externos à construtora, existem três fatores principais que condicionam o sucesso desta gestão: o primeiro se dá na etapa de projeto, etapa na qual se definem as características do empreendimento e portanto se estabelecem as especificações técnicas e de 
desempenho dos materiais. Esta etapa envolve tanto participantes externos (projetistas) quanto internos à empresa.

Já o segundo, é interno à empresa e diz respeito à forma como ela administra sua produção. O último envolve tanto a participantes externos (fornecedores) quanto internos e refere-se à gestão da cadeia de suprimentos. A seguir detalham-se os fatores anteriormente mencionados e sua relação com gestão de materiais.

\subsubsection{Gestão de projetos}

Segundo MELHADO (1994) o projeto pode ser entendido como "uma atividade ou serviço integrante do processo de construção, responsável pelo desenvolvimento, organização e registro das características fisicas e tecnológicas especificadas para uma obra, a serem consideradas na fase de execução”.

O CII (1987) ${ }^{4}$ apud MELHADO; AGOPYAN (1995) reconhece que é uma das etapas que tem maior capacidade de influenciar o custo final do empreendimento. Neste sentido, MELHADO; AGOPYAN (1995) afirmam que "a atividade de projeto deve ser entendida como instrumento fundamental para o aumento da competitividade da empresa...".

Portanto, a mesma deve ser elaborada com extremo cuidado, fornecendo não somente informações do "o que fazer" - projeto de produto - mas também sobre "o como fazer" projetos para produção.

BARROS (1996) define projeto para produção como: "um conjunto de elementos de projeto elaborados segundo características e recursos próprios da empresa construtoras, para utilização no âmbito das atividades de produção em obra, contendo as definições dos itens essenciais à realização de uma atividade ou serviço e, em 
particular: especificações dos detalhes e técnicas construtivas a serem empregados, disposição e seqüência de atividades de obra e frentes de serviço e uso e características de equipamentos”.

Além disso, a mesma autora ressalta que os projetos de produção são indispensáveis para que a etapa de produção ocorra de maneira planejada e que suas atividades sejam devidamente acompanhadas para assim se obter um produto cuja qualidade seja compatível com a especificada.

Segundo a definição colocada, a relação do projeto com a gestão de materiais é clara, cabendo ao projeto dar inicio à gestão de materiais, definindo claramente os recursos que deverão ser adquiridos e fornecendo os referenciais de controle desses insumos.

BARROS (1996) salienta que "sem as especificações de projeto, o departamento de suprimentos não terá parâmetros técnicos para (...) realizar a seleção de fornecedores e efetuar a requisição”.

Para explicar melhor a forma como a etapa de projeto relaciona-se com a gestão de materiais, a seguir apresenta-se um modelo de gestão empresarial contemporâneo, chamado Gestão da Qualidade Total. Considera-se importante incluir este modelo de gestão devido às novas visões e conceitos que aporta à gestão de empresas e ao peso que ele outorga às especificações técnicas, procedimentos e gestão de materiais na determinação da qualidade do empreendimento.

\subsubsection{Gestão da Qualidade Total (TQM)}

O conceito de qualidade tem sido definido por vários autores e organizações. Embora não exista uma definição universal de qualidade, existem alguns pontos em comum em

${ }^{4}$ CONSTRUCTION INDUSTRY INSTITUTE. Constructability: A Primer. 2.ed. Austin, 1987. (CII publication n. 3-1). 
todas as definições propostas (ISO 9000:2000; GOETSCH; DAVIS, 1994; PICCHI, 1993, DOBLER; BURT, 1996), quais sejam: qualidade está relacionada com satisfazer às necessidades e às expectativas do cliente; o conceito de qualidade se aplica a produtos, serviços, processos e ambientes; a qualidade está mudando continuamente.

Sendo assim, GOETSCH; DAVIS (1994) definem qualidade como: "um estado dinâmico associado a produtos, serviços, pessoas, processo e ambientes que satisfaz ou excede as expectativas do cliente".

Já a gestão de qualidade total é um modelo de gestão centrado na qualidade, baseado na participação de todos os membros da organização com o intuito de satisfazer ao cliente final (DOBLER; BURT, 1996). Estes mesmos autores destacam que entre seus elementos claves se considera: a noção que a qualidade é responsabilidade de todos; o comprometimento e participação ativa de todos os indivíduos na organização; a melhoria continua da qualidade e a satisfação do cliente.

Nas atividades industriais e nos negócios, o conceito da qualidade está definido em termos de sua relação com uma necessidade ou função. Nestes casos o importante é que a capacidade de um determinado item satisfaça a uma necessidade. Os projetistas, usuários e compradores devem, portanto, desenvolver especificações as quais definam claramente as características da qualidade necessárias para a satisfação de determinada função. Assim, no desenvolvimento de especificações de produtos ou materiais, qualidade é definida de acordo com a necessidade ou a função que se quer que eles cumpram.

Uma vez finalizadas as especificações, os requisitos estarão estabelecidos para aqueles que no futuro irão trabalhar com tais produtos. Nesse caso, qualidade é alcançar conformidade com os requisitos estabelecidos (DOBLER; BURT, 1996). 
Atualmente, a própria versão 2000 em discussão da série de normas NBR ISO 9000, além de ter como função principal a certificação de empresas, serve também para apoiar as organizações, de todos tipos e tamanhos, na implementação e operação de sistemas da qualidade eficazes. Assim a futura NBR ISO 9000 (ABNT, 2000a) descreverá os fundamentos de sistemas de gestão da qualidade e estabelecerá a terminologia para estes sistemas. A futura NBR ISO 9001 (ABNT, 2000b) especificará requisitos para um sistema de gestão da qualidade, onde uma organização precisará demonstrar sua capacidade para fornecer produtos que atendam aos requisitos do cliente e aos requisitos regulamentares aplicáveis, sendo que objetiva aumentar a satisfação do cliente; a futura NBR ISO 9004 (ABNT, 2000c) fornecerá diretrizes que consideram tanto a eficácia como a eficiência do sistema de gestão da qualidade; e, finalmente, a futura NBR ISO 19011 as diretrizes sobre auditoria de sistemas de gestão da qualidade e ambiental.

\subsection{Papel da gestão de materiais no TQM}

A importância da gestão de materiais na qualidade pode ser inicialmente avaliada pelo impacto que este tem recurso e as perdas com ele relacionadas representam no custo final de um produto edificado. Os resultados de pesquisa nacional sobre o assunto, coordenada pela Escola Politécnica - Departamento de Engenharia de Construção Civil, mostram que, para materiais tradicionais como concreto, aço em barras, blocos e tijolos, e componentes cerâmicos, a relação entre perdas e consumos nos canteiros pode atingir picos de 50\%, com valores medianos da amostragem entre 9 e 14\% (AGOPYAN et al., 1998).

Por outro lado, segundo PICCHI (1993) "a qualidade da função suprimentos 5 deve ser analisada não só quanto à atividade da compra, mas também quanto ao planejamento e

\footnotetext{
${ }^{5}$ Entendendo-se a função suprimentos como "o sistema de planejar e controlar todos os esforços para garantir que a correta qualidade e quantidade de materiais e equipamentos estejam corretamente
} 
controle, abastecimento, armazenamento, etc., levando em conta todas as áreas envolvidas no processo (projeto, especificações, produção, qualidade e suprimentos)”.

Uma das responsabilidades mais importantes da área de suprimentos da empresa é a de assegurar que os fornecedores tenham a capacidade e a informação adequada para fornecer materiais e componentes na qualidade especificada, ao menor custo e no prazo correto.

Para DOBLER; BURT (1996), na indústria manufatureira, existem quatro fatores que determinam o grau de qualidade dos materiais comprados:

1. criação de especificações adequadas e completas indicando os requisitos de qualidade;

2. entendimento realístico dos requisitos de qualidade pelos fornecedores;

3. seleção de fornecedores que tenham capacidades técnicas e produtivas para cumprir a qualidade/custo especificado;

4. monitoramento e controle do desempenho dos fornecedores no cumprimento dos requisitos da qualidade, prazo e custo.

A seguir aborda-se com maior detalhe os fatores indicados anteriormente tratando de entender se estes mesmos fatores podem ser os adequados para a indústria da construção.

Segundo DOBLER; BURT (1996), as especificações são o método mais detalhado para descrever requisitos. Nelas devem estar explicitados os requisitos de projeto, os fatores referentes à produção, as considerações no momento da compra, entrega e recebimento do material. Estes mesmos autores afirmam que o desenvolvimento de especificações é uma tarefa gerencial que envolve muitas variáveis, por isso, seu sucesso está 
condicionado à participação das diversas áreas da empresa (projetos, produção, compras, etc.) na sua elaboração.

Para o caso da construção de edificações é importante lembrar que, na maior parte dos casos, as pessoas que participam dos projetos, produção e compras trabalham sob regimes contratuais distintos, pelo qual é difícil fazer que trabalhem concomitantemente para a elaboração das especificações. Ainda mais, freqüentemente, os materiais são decididos no momento da compra, já que muitas vezes se apresenta a oportunidade da compra de um material mais econômico. É prática usual, portanto, postergar estas decisões para o momento da compra do material, durante a obra.

Uma possível solução para esta característica do setor seria a de não se definir a especificação na etapa do projeto, mas indicar, além das características técnicas necessárias, as características de desempenho que se desejam atingir, sem chegar a colocar uma determinada marca ou nome de um produto, ou sugerindo os possíveis materiais existentes no mercado que cumpram com estas características.

CHARETTE; MARSHAL (1999) referem-se a este tipo de especificações como “especificações de desempenho" e afirmam que elas estabelecem resultados que se querem atingir mas sem indicar os meios para os atingir. Adicionalmente afirmam que este tipo de especificações fomenta o uso da criatividade e inovação para cumprir com os requisitos da forma a mais econômica.

Desta maneira, proporciona-se maior flexibilidade para que as decisões possam ser tomadas seja no momento de "fechar" o orçamento ou no momento de iniciar a requisição do material, mas sempre atendendo às características presentes na especificação inicial.

quando necessário” (BERNOLD; TERSELER, 1991 apud PICCHI, 1993). 
Em conseqüência, existem dois momentos chaves na elaboração das especificações de materiais que não estejam completamente definidos na etapa de projeto mas indicados através das características de desempenho que se quer atingir:

(i) especificação inicial: na qual os projetistas e agentes competentes devem indicar as características técnicas, de desempenho, visuais, de rugosidade, etc. que conduzam a que no momento da requisição a escolha do material se realize com os parâmetros adequados e da maneira mais rápida possível;

(ii) especificação final: realizada com base nos parâmetros estabelecidos no projeto e levando adicionalmente em conta fatores econômicos. O sucesso desta etapa final vai depender em grande parte da pessoa encarregada desta decisão. Sendo que a requisição do material parte da obra, o engenheiro a cargo da obra seria a pessoa correta para decidir sobre a escolha do material.

Os documentos de compra e negociação devem incluir estas especificações, além dos procedimentos de inspeção e critérios de aprovação. Desta forma, se estabelece claramente com o fornecedor o que se está comprando e a qualidade requerida, sem deixar ambigüidades a serem resolvidas no momento que ocorra uma nãoconformidade.

A boa seleção do fornecedor é peça chave para se obter um material com a qualidade requerida, a tempo e ao menor custo. Para tal, DOBLER; BURT (1996) recomendam levar em conta as seguintes considerações no caso da indústria manufatureira:

- desenvolver e manter uma base de fornecedores: esta base deve incluir tanto os fornecedores atuais quanto os passados, a lista dos produtos ou serviços que cada um deles oferece, seu desempenho nas entregas, na qualidade de seus produtos, em seu serviço pós-entrega, etc. 
- Trabalhar com um número limitado de fornecedores. Isso pode trazer consigo as seguintes vantagens:

(i) fazer com que o fornecedor participe do projeto desde as suas etapas iniciais, obtendo assim sugestões dos fornecedores antes de terminados os projetos para poder neles incorporá-las;

(ii) trabalhar com os fornecedores na implementação de programas de melhoria continua;

(iii)estabelecer formas de comunicação que facilitem a rápida solução de problemas e evitem atrasos, etc.

- Assegurar que os fornecedores sejam cuidadosamente avaliados: as empresas deverão ter procedimentos formalizados para avaliação do desempenho do fornecedor e assim prover um retorno ao sistema.

No caso da construção de edifícios, o primeiro e o último ponto são totalmente viáveis; já o segundo merece ser melhor analisado. $\mathrm{O}$ trabalhar com um número limitado de fornecedores traz para a indústria manufatureira e automobilística vantagens, já que via de regra nessas indústrias o fornecedor é contratado para produzir um produto já desenvolvido pelo departamento de engenharia da empresa. Desta maneira, a empresa possui domínio sobre o processo de produção desse novo produto e conhece o seu custo aproximado. A fornecedora produz assim o produto encomendado e torna-se parceira da empresa, as duas conseguindo otimizar seus custos.

No caso da empresa construtora a situação pode ser muito distinta já que ela pode não possuir o domínio sobre o processo de produção do novo produto, este conhecimento sendo do fornecedor. Portanto, tal fornecedor, nessas situações, pode decidir sobre o preço do produto ou serviço fornecido, que pode assim tornar-se elevado. 
Por outro lado, para trabalhar com um número limitado de fornecedores deve-se avaliar a conseqüente relação custo-beneficio já que isso poderia diminuir as vantagens que podem ser adquiridas devido à competição entre eles. Nesse caso é interessante estabelecer para quais materiais é conveniente trabalhar com um número limitado de fornecedores e para quais não é tão vantajosa esta proposta.

Para fornecedores que vendam produtos como matérias primas e componentes, por exemplo, onde os fornecedores geralmente são distribuidores e não fabricantes e existe muita concorrência entre eles, talvez não seja interessante restringir o número de fornecedores. Porém, existem casos onde empresas têm estabelecido parcerias com este tipo de fornecedores - produtores para desenvolver e melhorar o produto.

No entanto, analisando as empresas do subsetor de edificações comprova-se que a maioria delas trabalham com um número limitado de fornecedores de matérias primas e componentes, sendo o principal motivo desta prática a reduzida base de fornecedores qualificados que existe no setor. Uma possível solução que vem aparecendo no setor são os sistemas de avaliação de fornecedores disponíveis na Internet, como o SAFO Sistema de avaliação de Fornecedores (http://www.safonaobra.com.br/). Estes sistemas permitem ampliar a base de dados de fornecedores das empresas, possibilitando a empresa construtora conseguir melhores preços através da maior competição entre fornecedores.

Já para outros produtos, como os produtos feitos sob pedido ou produtos terminados utilizados na etapa de acabamento, poderia resultar mais vantajoso trabalhar com um número limitado de fornecedores. Neste caso, geralmente os fornecedores são os produtores e, além disso, precisa-se de um maior contato com o fornecedor na obtenção de um produto com a qualidade requerida. Desta maneira, uma relação mais estreita e 
duradoura com o fornecedor favoreceria os resultados. Neste caso também é interessante pensar na consolidação de parcerias com o fornecedor.

Depois de selecionar ao fornecedor o seguinte passo será o de monitorar e controlar a entrega de materiais na obra. Para tal, a empresa deverá estabelecer seus procedimentos de recepção, manuseio e armazenamento de materiais. Embora estes documentos não sejam elaborados na etapa do projeto, os mesmos, em conjunto com os projetos, garantem que a obra seja executada conforme a qualidade estabelecida.

Quanto aos procedimentos de recepção, estes devem garantir que o produto seja entregue atendendo aos requisitos de qualidade estabelecidos. Os conceitos de gestão atuais tratam de garantir a qualidade do produto com um mínimo de inspeção, já que esta é uma etapa que não agrega valor ao produto. Nesse sentido PICCHI (1993) afirma que "a eliminação da inspeção de recebimento, depende não só do estreitamento das relações comprador - fornecedor, mas também da evolução do parque industrial do país, no que diz respeito à gestão da qualidade, bem como à existência de infraestrutura de Tecnologia Industrial Básica (normalização, laboratórios, instituições certificadoras, etc.)".

Como exemplo de como o estado pode contribuir na evolução do parque industrial no referente à qualidade, cita-se o Programa da Qualidade na Construção Habitacional do Estado de São Paulo - QUALIHAB da Companhia de Desenvolvimento Habitacional e Urbano do Estado de São Paulo - CDHU. Trata-se de um programa do estado de São Paulo para garantir a qualidade na habitação popular. O estado exerce seu poder de compra exigindo que as empresas construtoras implantem sistemas evolutivos de qualidade e os qualifiquem segundo mecanismos do programa para poder participar nas 
licitações. Cria-se desta maneira uma "cadeia de qualidade" onde o estado exige qualidade das empresas construtoras e estas de seus fornecedores.

Do mesmo modo, a CDHU tem exigido que os produtos empregados em suas obras obedeçam a padrões mínimos e evolutivos de qualidade. Também tem agido junto a outros participantes da cadeia, como empresas de serviços topográficos, de geotecnia e fundações, laboratórios de ensaio e projetistas.

É importante colocar que atualmente, além do programa estadual levado diante pela CDHU, existe um programa nacional PBQP-H - Programa Brasileiro da Qualidade e Produtividade do Habitat - que também procura garantir a qualidade da habitação popular. Uma das ações mais importantes nesse sentido e a Meta Mobilizadora da Habitação, que visa aumentar para 90\%, até 2002, o respeito à normalização (conformidade), pelos produtos que fazem parte da cesta básica de materiais. Assim, desde já o impacto da qualidade no setor vem se dando não somente no âmbito estadual mas também nacional.

Quanto aos procedimentos de manuseio e armazenamento, PICCHI (1993) aponta que os mesmos devem conter:

- "procedimentos de manuseio: segurança do operador e do produto, cuidados especiais com materiais inflamáveis, corrosivos, etc.; equipamentos adequados para manuseio;

- procedimentos de armazenagem: critério para localização do produto, facilidade de acesso de pessoal e equipamentos, condições especiais de preservação, controle quantitativo do estoque, quantidade mínima para efeito empilhamento, identificação do material, bem como de seu estado e prazo de validade, quando aplicável, limpeza dos locais de armazenamento." 
Um outro conceito que traz consigo a gestão da qualidade é o da definição das funções e responsabilidades de todos os membros da empresa, assim como também o da determinação do perfil dos funcionários para cada trabalho específico.

Estes aspectos remetem a um ponto importante: o da certificação de sistemas via a serie de Normas ISO 9000, pensando-se na Garantia da Qualidade. Com sua nova versão, que passará a vigorar internacionalmente a partir de dezembro do 2000 e cuja versão brasileira está em processo de aprovação (ABNT, 2000a, 2000b e 2000c), a distinção que existia entre "gestão" e "certificação" da qualidade se atenuará muito.

Assim, quando se pensa em gestão de materiais, a antiga serie de 1994, assim com a proximamente vigente, trazem novos pontos que devem ser considerados: a visão de gestão de materiais como um processo composto por outros processos; a análise crítica de contratos; a necessidade da importância da qualidade crítica de projetos.

Em resumo, a Gestão da Qualidade Total e a Garantia da Qualidade colocam a gestão de materiais como elemento estratégico para a obtenção da qualidade do produto final e estabelece a formalização da empresa como um modo de se conseguir qualidade nesta gestão. Ressalta-se, assim, a importância da:

- criação de especificações para os materiais, tanto técnicas quanto as de desempenho;

- criação de procedimentos para a compra, seleção e avaliação do fornecedor, recepção, manuseio e armazenagem;

- definição das funções e responsabilidades dos funcionários da empresa;

- definição do perfil do funcionário para cada cargo;

- realização das análises críticas de projeto e de contrato;

- a visão de processo. 
Por último, sugere também, que a relação fornecedor \& comprador deve começar em alguns casos desde as etapas inicias do projeto para conseguir aproveitar ao máximo a experiência e conhecimento do primeiro.

\subsubsection{Gestão da produção}

Neste item não se pretende discutir todas as formas de gestão da produção que vêm sendo utilizadas nos últimos anos nas empresas construtoras, mas tão somente apresentar aquelas que abordem aspectos que possam agregar valor à pesquisa e que forneçam elementos a serem incorporados na formulação das diretrizes propostas no objetivo principal deste trabalho.

A gestão da produção pode ser entendida como a forma como a empresa planeja, coordena, executa e controla suas atividades de produção. É interessante notar que, apesar da gestão de materiais ser um requisito indispensável para o sucesso da gestão da produção, a sua importância em uma determinada empresa vai ser potencializada em função do modelo de gestão da produção por ela utilizado.

A seguir abordam-se dois novos modelos conceituais de gestão da produção que vêm sendo utilizado nos últimos anos, destacando a forma que eles valoriza a gestão de materiais. O primeiro, o Just-in-Time (JIT), é aplicado principalmente na indústria manufatureira. O segundo, a Lean Construction, é um modelo de gestão da produção específico para a construção, baseado no TQM e no JIT e que evolui a partir de uma corrente genérica, a Lean Production.

\subsubsection{Just-in-Time (JIT)}

O Just-in-Time é um modelo de gestão da produção que surgiu na indústria automotriz e que busca eliminar as perdas tanto nos processos de produção quanto nas atividades que suportam estes processos (GOETSH; DAVIS, 1994). 
Segundo esta nova visão os estoques são sinônimo de perdas e ocultam problemas e ineficiências do sistema, e devem ser eliminados ou otimizados já que não agregam valor (CHRISTOPHER, 1992; GOETSH; DAVIS, 1994). A idéia é a de produzir o que se precisa, no momento que se precisa e na quantidade requerida.

Para conseguir eliminar efetivamente as perdas, seus princípios devem ser implementados tanto na empresa construtora quanto em seus fornecedores. Portanto, exige-se muita coordenação e comunicação entre estes agentes para implementá-los corretamente.

Este modelo está baseado em uma produção pró-ativa ao invés da tradicionalmente utilizada, a qual é reativa. Na produção pró-ativa, quem inicia o processo é o cliente final, e a idéia é produzir somente o que está pedido, eliminando assim os estoques de produtos e materiais, nos quais se apoia a produção reativa. É a idéia da produção “puxada” em oposição à de produção “empurrada”.

O JIT considera além do cliente final, o conceito do cliente interno, que também é valorizado no TQM. Analisando o processo de produção observa-se que ao longo dele vão aparecer muitos fornecedores e clientes, cada processo precedente é um fornecedor e quem recebe este processo ou produto derivado é um cliente. Com este novo conceito nenhum processo é acionado até ter uma demanda do processo subsequente, eliminando assim os estoques.

O seu criador, Taiichi Ohno, identificou sete formas de perdas que procurou combater (GOETSH; DAVIS, 1994): na superprodução; na espera; no transporte; no processamento; nos estoques desnecessários; na locomoção desnecessária; na produção de produtos defeituosos. 
Contrariamente à produção em massa que se respalda nos estoques para assegurar a continuidade da produção o JIT enfoca seus esforços em se antecipar aos problemas e se implementar soluções.

No entanto, o fato de trabalhar sem estoques implica um risco. Portanto, um novo enfoque deve ser dado ao sistema para fazê-lo realmente eficiente. A transparência e a confiabilidade do processo tornaram-se requisitos indispensáveis para atingir este novo objetivo. Para tal, foram implantados a manutenção preventiva, o uso do sistema $\operatorname{Kanban~}^{6}$ para o controle da produção e o planejamento detalhado da produção.

O planejamento da produção consiste na fixação de objetivos para a produção sobre o que se deve produzir, quando, como e por quem (SILVA, 2000a). O objetivo do planejamento da produção e das atividades de controle é o de coordenar o uso dos recursos da empresa e sincronizar o trabalho de todo o pessoal de produção para cumprir com os prazos, ao menor custo e com a qualidade desejada (DOBLER; BURT, 1996).

Para estes últimos autores, um planejamento eficaz da produção deve conter as seguintes atividades: planejamento preliminar (determinação dos requisitos de materiais, mão-de-obra, equipamento e ferramentas segundo os projetos); cronograma global; cronograma de detalhado; controles e atualização dos cronogramas anteriores.

$\mathrm{Na}$ industria seriada, o planejamento da produção que suporta o JIT se faz hoje em dia através de sistemas informatizados que não somente gerenciam a produção como também integram as atividades de toda a empresa e, além disso, permitem uma integração com os fornecedores.

\footnotetext{
${ }^{6} \mathrm{O}$ Kanban é um sistema de informação que aciona e controla a produção. Seu nome deriva do cartão que identifica a quantidade a ser produzida e ao mesmo tempo dá instruções de trabalho, controla visualmente o volume de produção, previne o excesso de produção e indica problemas no processo (SILVA, 2000a).
} 
O sistema MRP (Material Requirement Planning), o qual será explicado com maior detalhe no Capítulo 4, surgiu na década de sessenta como uma técnica para determinar as quantidades e os prazos dos materiais requeridos pela produção. O MRP, também conhecido como MRP I, evoluiu para o MRP II (Manufacturing Resource Planning) o qual é um plano global para o planejamento e o controle de todos os recursos de uma empresa. A evolução do MRP são os sistemas conhecidos com ERP (Enterprise Resource Planning), que são sistemas estruturados sobre os processo da empresa. Destacam-se na categoria ERP os sistemas SAP (alemão), BAAN (holandês) e Oracle (americano). Porém, estes sistemas são caros e seu uso se restringe a empresas com elevado poder de investimento.

É importante mencionar que, assim como todos modelos de gestão da produção, o JIT deve ser implementado dentro de um sistema de gestão que propicie seu desenvolvimento. GOETSH; DAVIS (1994) afirmam que o JIT precisa de um contexto de Gestão de Qualidade Total (TQM) para que seus benefícios podam ser potencializados.

\subsubsection{Lean Construction (Produção Enxuta)}

Já na industria da construção civil, KOSKELA (1992) baseou-se neste modelo de gestão para propor a nova filosofia de gestão da produção, chamada Lean Construction. Contrariamente à forma tradicional de gerir a produção, concebe o empreendimento como um sistema e não como uma soma de atividades isoladas. Similarmente ao JIT baseia-se em uma produção pró-ativa.

É esta visão sistêmica que a distingue da prática corrente da gestão da produção. Enquanto o modo tradicional representa a produção como um conjunto de atividades de conversão, a filosofia lean modela o processo como um fluxo, o qual inclui atividades 
de conversão, inspeção, movimentação, espera e adicionalmente incorpora um enfoque de geração de valor.

O modelo de gestão tradicional, ao agrupar os processos em atividades de conversão, oculta as perdas identificadas por Taiichi Ohno. Como consequiência não torna possível se enxergar uma fonte potencial de melhoria. Por outro lado, o modelo que inclui tanto as atividades de conversão quanto as de movimentação, inspeção e espera, representa mais fielmente o que acontece na produção e permite encontrar fontes de possíveis ineficiências no processo.

A idéia básica é a de se tentar minimizar as atividades que não agregam valor e se otimizar as que agregam valor. É claro que existem atividades que não agregam valor mas que são necessárias para respaldar as outras que o agregam, como é o caso da logística. Nesses casos, deve se tratar de minimizar estas atividades para que possam cumprir com sua função de suportar eficazmente as outras atividades que agregam valor.

No caso da construção de edifícios é importante lembrar que sendo o produto edifício um bem imóvel, outra forma de estoque (perda) se induz quando o produto ou parte dele é terminado seja muito antes da entrega do edifício seja antes do momento quando tal parte for necessária para dar continuidade à produção de uma etapa a ela subsequente, incorrendo tanto em custos de oportunidade quanto em custos de vigilância. Consequentemente, usando os conceitos da Lean Construction ou do JIT a idéia seria tratar de eliminar também este tipo de estoque retardando a montagem o máximo possível. Assim, este fator converte-se em um condicionante adicional para implementar estes modelos no subsetor. 
Para conseguir este objetivo, um fator chave é a existência de um planejamento da produção confiável e detalhado. No entanto, na construção de edifícios, o planejamento ainda se encontra em um estágio inferior quando comparado com o da indústria seriada. A elevada incerteza que envolve tanto o produto quanto o processo construtivo faz com que um bom planejamento da produção seja muito difícil de se obter. Esta incerteza é inerente ao produto, já que o produto edifício é um tipo de produto para o qual não existe uma "solução" única mas inúmeras possíveis soluções. Além disso, a incerteza pode ser incrementada por projetos mal especificados ou incompletos, pelo não cumprimento do previsto por parte dos fornecedores, pela falta de domínio da tecnologia, por problemas devidos ao cliente ou a fatores ambientais, etc.

DAVIS (1993) afirma que é importante identificar e entender as razões que reduzem a confiabilidade no processo e incrementam a incerteza para encontrar a forma de as reduzir ou estar preparados para reagir a elas quando acontecerem.

BALLARD; HOWELL (1998) propõem um planejamento da produção em três níveis para a construção. Em um primeiro nível, faz-se um planejamento inicial global de toda a produção; em um segundo nível, o do Lookahead Planning, realiza-se uma previsão mais detalhada para o curto prazo (a cada duas ou três semanas), para ajustar o cronograma e para disparar o processo de mobilização de recursos. Em um terceiro nível, faz-se um planejamento de compromissos das atividades que devem ser realizadas em um prazo ainda mais curto (uma semana), detalhando as necessidades de recursos para a execução de atividades e as tarefas de cada dia.

O interessante desta proposta é que a cada semana deve-se identificar e registrar as causas que levaram ao não cumprimento do planejamento, para que assim a pessoa que 
realiza o planejamento as tenha em conta para fazer o planejamento da semana seguinte. A idéia é que o planificador aprenda a planejar de modo confiável apesar das incertezas. Em resumo, a gestão de materiais se constitui em um elemento indispensável para a implementação do JIT. Este modelo de gestão da produção agrega um requisito à gestão de materiais que é o de se trabalhar com estoques mínimos ou nulos.

Já o modelo da Lean Construction, que está baseado nos conceitos do JIT e do TQM, aponta o modelamento da produção como um fluxo tendo em consideração não somente as atividades de conversão mas também as de movimentação, espera, inspeção e estocagem (de fluxo). Destaca que estas últimas não agregam valor ao sistema e portanto devem ser minimizadas ou eliminadas. É importante notar que a aplicação dos conceitos do JIT depende de uma relação com os fornecedores muito estreita (por exemplo, na indústria automobilística foi inclusive fundamental o estabelecimento de parcerias com os fornecedores). Por último, o JIT se baseia em um planejamento sólido da produção para garantir os recursos quando necessitados.

\subsubsection{A gestão da cadeia de suprimentos}

$\mathrm{O}$ terceiro fator indicado como condicionante para conseguir uma boa gestão de materiais é a gestão da cadeia de suprimentos. A seguir pretende-se explicar com mais detalhe o que seja a cadeia de suprimentos e como está sendo abordado esse tema na indústria da construção sob o ponto de vista da empresa construtora. Para tal, caracteriza-se os fornecedores da empresa construtora, ressaltando-se as características particulares dos fornecedores de materiais.

Como já foi discutido, a cadeia de suprimentos é um conceito relativamente novo que apareceu após um processo de evolução e amadurecimento da atividade logística na indústria da manufatura. 
O termo cadeia de suprimentos tem sido definido por vários autores. POIRIER; REITER (1996) ${ }^{7}$ apud LONDON et al. (1998), por exemplo, definem a cadeia de suprimentos como um sistema através do qual as organizações distribuem seus produtos e serviços a seus clientes e assim sucessivamente. Esta cadeia, centrada na empresa, vai desde os fornecedores de seus fornecedores até os clientes de seus clientes, conforme visto na Figura 1.

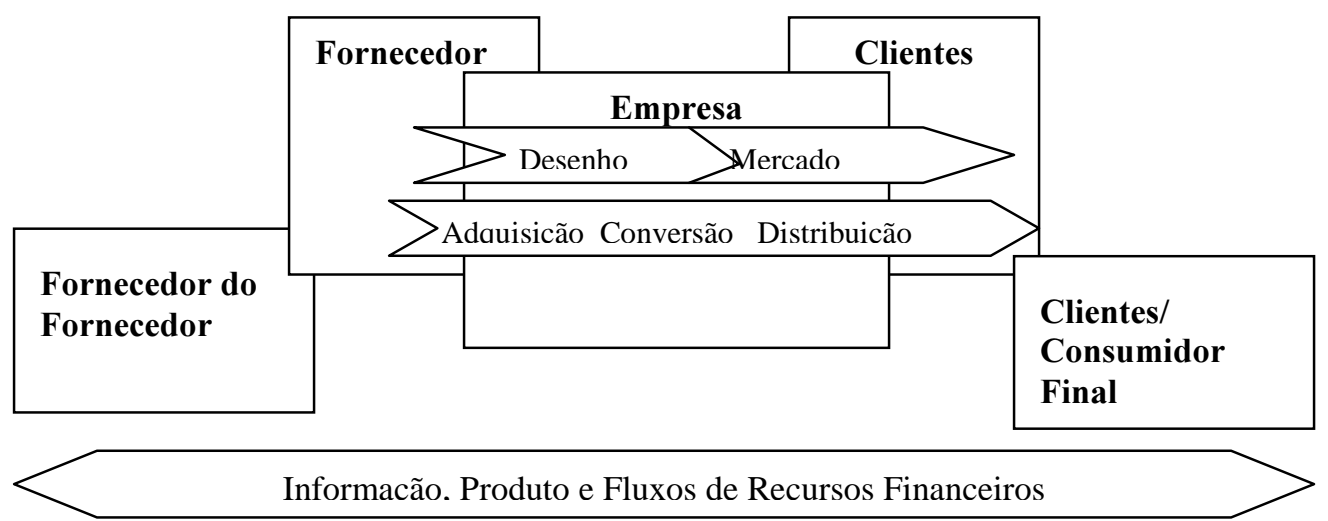

Figura 1.- Cadeia de suprimentos (POIRIER; REITER, 1996 apud LONDON et al.,1998)

Já CHRISTOPHER (1992) dá uma interpretação na qual sugere que a fase de produção não deve ser vista isoladamente, já que as decisões anteriores a ela afetam o empreendimento significativamente e portanto são componentes integrais da cadeia de suprimentos.

Sendo assim, este autor define a cadeia de suprimentos "como a rede de organizações que se interrelacionam através de enlaces em ambos sentidos, nos diversos processos e atividades que produzem valor na forma de produtos e serviços nas mãos do consumidor final'".

JOHNSON, WOOD (1996) destacam que o termo da cadeia de suprimentos estende o conceito da integração além da empresa para todas as empresas da cadeia. Fornecedores

${ }^{7}$ POIRIER; REITER. Supply chain optimization: building the strongest building network. USA, BerrettKoehler Plublishers, 1996. 
e clientes compartilham informações e planos necessários para que o canal seja mais eficiente e competitivo.

Estes mesmos autores afirmam que, levando-se em consideração o conceito da cadeia de suprimentos, é aceitável negociar mudanças nos desenhos e na engenharia dos produtos para fazer-lhes mais compatíveis com as necessidades dos outros membros da cadeia. A empresa e todos seus fornecedores estariam tratando de fornecer um produto com qualidade através de um sistema com qualidade e para atingir-se este objetivo deve-se envolver todas as funções da empresa. Para eles, o conceito da cadeia de suprimentos traz consigo espaço para considerar a reengenharia de produtos e processos, de modo que o fluxo em toda a cadeia seja contínuo e sem interferências.

Um outro ponto importante que tem aparecido com o conceito da cadeia de suprimentos é a formação de parcerias ou alianças estratégicas entre as empresas da cadeia. A idéia é que estas parcerias tragam benefícios mútuos para as empresas envolvidas. Para POIRIER; HOUSER (1993) apud GOETSCH; DAVIS (1994) a “verdadeira parceira com os fornecedores requer um entendimento das necessidades e capacidades de cada parte, para estabelecer uma visão clara de onde devem ser focados os esforços das pessoas que trabalham tanto para o fornecedor como para o comprador (empresa)... A meta é criar e manter uma relação leal e confiável que faça com que ambos os sócios ganhem promovendo uma melhoria continua de qualidade, produtividade e competitividade."

DOBLER; BURT (1996) colocam que os principais requisitos para a criação de parcerias são: (i) compatibilidade de interesses; (ii) necessidade mútua; (iii) boa disposição para compartir informações e benefícios obtidos; (iv) confiança. 
O sucesso do JIT na indústria automotriz, por exemplo, não teria sido possível sem a formação de parcerias entre seus fornecedores e clientes.

Portanto, a gestão da cadeia de suprimentos constitui-se em um conceito básico para a conseguir una gestão de materiais eficiente dentro de uma empresa. Parte da premissa de que nenhuma empresa é completamente auto-suficiente mas depende de muitas outras para poder trabalhar. Coloca assim todas as empresas da cadeia dentro de um sistema onde o principal objetivo é satisfazer ao cliente final. Para tal, traz consigo novos conceitos que permitam que isto seja possível, dentre os quais o de parceria, que em essência supõe o alinhamento estratégico entre empresas e a confiança mútua.

A seguir aborda-se este conceito para a indústria da construção.

\subsubsection{A cadeia de suprimentos na industria da construção}

A importância de uma análise detalhada da cadeia de suprimentos na industria da construção tem sido recentemente reconhecida pelo meio acadêmico (O'BRIEN, 1995; VRIJHOEF; KOSKELA, 1999, LONDON et al.,1998).

LONDON et al. (1998) afirmam que para o estudo da cadeia de suprimentos na construção civil existem duas correntes de pensamento. A primeira é associada com a logística de suprimentos e a idéia é a de reduzir as perdas através de gestão eficiente dos fluxos de recursos para o canteiro. Este enfoque se concentra na logística do processo construtivo, quer dizer, concentra-se basicamente no contratante e nos fornecedores e nos subempreiteiros agrupados em torno dele.

A segunda corrente está associada ao pensamento lean e busca criar valor através de toda a cadeia de suprimentos. LONDON et al. (1998) agregam que estas duas correntes

8 POIRIER, C.; HOUSER, W. Business Partnering for Continuous Improvement, Berrett-Koehler Publishers, USA, 1993. 
de pensamento são válidas para o estudo da cadeia de suprimentos na construção civil e que simplesmente analisam os problemas de distintas perspectivas.

Analisando a cadeia de suprimentos na construção de edificações sob o primeiro enfoque anteriormente apresentado, observa-se que existem diversos agentes que intervêm no processo construtivo com a finalidade fornecer algum tipo de produto ou serviço durante o transcurso do empreendimento, quais sejam: projetistas; empresa construtora; empresa incorporadora; fornecedores de ferramentas e equipamentos; fornecedores de serviços (mão-de-obra); fornecedores de materiais; fornecedores de subsistemas; etc.

Para entender a natureza destes participantes, apresenta-se na Tabela 1 uma breve caracterização dos fornecedores deste setor. Esta tabela mostra a grande diversidade de agentes que participam do processo de produção (construção). É interessante notar que uma grande parte destes agentes não existia no mercado há poucos anos, quais sejam: projetistas de produção; corte e dobra de aço; fôrmas; "parede pronta"; entre outros.

Estes novos fornecedores são produto das mudanças que estão acontecendo no setor. A elevada competição faz com que as empresas construtoras tenham que otimizar seus custos para poder subsistir. Sendo assim, as empresas construtoras estão optando por delegar parte de sua produção a terceiros com o intuito de otimizá-la. Esta situação favorece a aparição de novos fornecedores e o aumento da dependência com o fornecedor por parte das empresas.

É interessante notar que todas estas mudanças fazem com que a gestão da cadeia de suprimentos na construção civil assuma atualmente extrema importância. A dependência cada vez maior nos fornecedores para a etapa de produção e a busca por 
parte das empresas de tecnologias e não simplesmente de materiais são fatores que indicam a força crescente que os fornecedores estão adquirindo.

Tabela 1.- Caracterização dos fornecedores no setor edificações

\begin{tabular}{|c|c|c|c|}
\hline AGENTE & $\begin{array}{c}\text { ETAPA DO } \\
\text { EMPREENDIMENTO }\end{array}$ & $\begin{array}{l}\text { TIPOS DE } \\
\text { FORNECEDORES } \\
\text { EXISTENTES NO } \\
\text { MERCADO }\end{array}$ & DESCRIÇÃO \\
\hline \multirow{6}{*}{$\begin{array}{l}\text { FORNECEDORES } \\
\text { DE PROJETO E } \\
\text { SERVIÇÔS } \\
\text { TÉCNICOS } \\
\text { ESPECIALIZADOS }\end{array}$} & \multirow{6}{*}{ Projeto / Construção } & $\begin{array}{c}\text { Projetos de produto: } \\
\text { arquitetura, estrutura, } \\
\text { instalações (mais comuns) }\end{array}$ & \multirow{6}{*}{$\begin{array}{l}\text { Setor da indústria da } \\
\text { construção civil } \\
\text { fragmentado, sem barreiras } \\
\text { de entrada e com muitos } \\
\text { concorrentes. }\end{array}$} \\
\hline & & $\begin{array}{l}\text { Projetos para produção: } \\
\text { fôrmas, alvenaria, corte e } \\
\text { dobra de aço, etc. }\end{array}$ & \\
\hline & & $\begin{array}{c}\text { Planejamento e } \\
\text { gerenciamento (consultoria) } \\
\end{array}$ & \\
\hline & & $\begin{array}{c}\text { Estudos de preparação e } \\
\text { desenvolvimento de métodos } \\
\text { construtivos }\end{array}$ & \\
\hline & & Orçamento & \\
\hline & & Engenharia de Segurança & \\
\hline $\begin{array}{l}\text { FORNECEDORES } \\
\text { DE } \\
\text { FERRAMENTAS E } \\
\text { EQUIPAMENTOS }\end{array}$ & Construção & $\begin{array}{c}\text { Grua; guincho; } \\
\text { escoramentos; elevadores de } \\
\text { carga; andaimes; balancins; } \\
\text { vibradores; etc. }\end{array}$ & $\begin{array}{l}\text { Setor da indústria da } \\
\text { construção civil } \\
\text { fragmentado, heterogêneo, } \\
\text { com diversas empresas que } \\
\text { vão desde o pequeno ao } \\
\text { grande porte e com diversos } \\
\text { níveis tecnológicos. }\end{array}$ \\
\hline $\begin{array}{l}\text { FORNECEDORES } \\
\text { DE SERVIÇOS }\end{array}$ & Construção & $\begin{array}{l}\text { Alvenaria, revestimentos } \\
\text { cerâmicos, instalações } \\
\text { prediais, corte e dobra de } \\
\text { aço, etc. }\end{array}$ & $\begin{array}{l}\text { Setor muito heterogêneo } \\
\text { que oferece serviço de mão- } \\
\text { de-obra. Em muitos casos é } \\
\text { constituído por } \\
\text { trabalhadores que se reúnem } \\
\text { para realizar um } \\
\text { determinado serviço. }\end{array}$ \\
\hline $\begin{array}{l}\text { FORNECEDORES } \\
\text { DE MATERIAIS }\end{array}$ & Construção & $\begin{array}{l}\text { Madeira; fôrmas e } \\
\text { escoramentos; aço e } \\
\text { armaduras; areia e } \\
\text { agregados; argamassas } \\
\text { ensacadas; cimento e cal; } \\
\text { concreto estrutural; } \\
\text { elementos de alvenaria; } \\
\text { componentes de instalações } \\
\text { elétricas; componentes de } \\
\text { instalações hidráulicas e } \\
\text { sanitárias; esquadrias; } \\
\text { revestimento cerâmicos; } \\
\text { louças e metais; tintas. }\end{array}$ & $\begin{array}{l}\text { Setor da indústria da } \\
\text { construção civil } \\
\text { fragmentado, heterogêneo, } \\
\text { com diversas empresas que } \\
\text { vão desde o pequeno ao } \\
\text { grande porte e com diversos } \\
\text { níveis tecnológicos. } \\
\text { A maioria destes } \\
\text { fornecedores não são os } \\
\text { fabricantes dos produtos, } \\
\text { mas simplesmente } \\
\text { intermediários que servem } \\
\text { de ligação entre o fabricante } \\
\text { e o canteiro de obras. }\end{array}$ \\
\hline $\begin{array}{l}\text { FORNECEDORES } \\
\text { DE SUBSISTEMAS }\end{array}$ & Construção & $\begin{array}{c}\text { Fôrmas; "parede pronta"; } \\
\text { corte e dobra de aço, } \\
\text { elevadores, esquadrias; pisos } \\
\text { de madeira, etc.. }\end{array}$ & $\begin{array}{c}\text { Inclui empresas que variam } \\
\text { de grande a pequeno porte, } \\
\text { que fornecem sistemas } \\
\text { completos. }\end{array}$ \\
\hline
\end{tabular}


Nesse sentido, SABBATINI (1998) coloca que a tendência das empresas construtoras é que elas passem a se converter em "empresas integradoras de sistemas complexos". Desta forma, produziriam edifícios integrando diversos subsistemas (estruturas, vedações, instalações, etc.) através de projeto e planejamento sistêmicos e de processos de gestão e controle específicos no canteiro. Para tal, o mesmo autor coloca como essencial a existência de empresas fornecedoras destes subsistemas com a competência necessária para cumprir com estas tarefas.

Por outro lado, cabe destacar o evento realizado em outubro de 2000 em São Paulo que reuniu os principais agentes envolvidos na cadeia produtiva do setor no Brasil, cuja discussões tiveram como ponto de partida o documento de SILVA (2000b). Nele destacou-se que um dos aspectos decisivos na integração da cadeia produtiva é a visão de cadeia de valor, em que todos os processos produtivos correspondem a uma parcela do valor agregado ao produto final. Além disso, afirmou-se que no Brasil o foco em um cliente comum a todos os agentes atuantes na produção ainda difícil de se obter devido à falta de integração e compatibilização dos interesses individuais de cada subsetor.

Nesse mesmo documento a autora coloca que para a melhoria da qualidade e produtividade da construção civil no Brasil vêm sendo identificadas as necessidades setoriais e regionais no interior da cadeia produtiva. A seguir destacam-se algumas destas necessidades:

- reciclagem e capacitação técnica: recapacitação de docentes; dirigentes empresariais; profissionais; e profissionais de laboratórios de controle tecnológico;

- desenvolvimento tecnológico para o desempenho dos edifícios: normalização técnica; certificação de produtos e sistemas construtivos; padronização dimensional; desenvolvimento de conhecimento específico para projeto; tecnologia de materiais e 
componentes; e visualização de uma estrutura de financiamento a máquinas e equipamentos, software e hardware.

- desenvolvimento de novos produtos e processos a partir de necessidades identificadas no processo produtivo e nas características de uso dos edifícios;

- desenvolvimento de métodos de gestão.

Assim demostra-se que no Brasil a cadeia de suprimentos já tem sido identificada pelo setor como um condicionante na busca da melhoria da qualidade e produtividade para construção e por esse motivo estão se tomando ações que conduzam à integração da mesma.

Concluindo-se, precisa-se de uma gestão eficiente da cadeia de suprimentos para garantir o sucesso do processo construtivo. Este sucesso dependerá não somente dos meios que a empresa construtora utilize para coordenar todos estes participantes para fazer com que trabalhem como uma unidade, como principalmente das iniciativas do setor como um todo para integrar a cadeia produtiva. Mecanismos eficazes de comunicação e de tomadas de decisão passaram a ser indispensáveis para satisfazer estas exigências de coordenação.

Sendo que este trabalho baseia-se especificamente na gestão de materiais, no próximo item analisa-se com mais detalhes os dois últimos tipos de fornecedores apresentados na Tabela 1, quais sejam: fornecedores de materiais e de subsistemas (inclui material e mão-de-obra).

\subsubsection{Fornecedores de materiais e de subsistemas}

Focalizando-se nestes fornecedores, segundo o escopo deste trabalho, observa-se que eles representam um setor da indústria muito heterogêneo, tanto no que diz respeito aos produtos em si quanto aos perfis de seus fornecedores. Além disso, muitas vezes estes 
fornecedores não são os produtores propriamente ditos mas agentes intermediários ou distribuidores dos mesmos.

Todas estas características próprias do setor e de cada empresa em particular terminam por influenciar suas formas de negociação, entrega, recebimento, estocagem e atendimento ao cliente. Portanto, torna-se indispensável levar estas características em conta para conseguir que estes agentes trabalhem como uma unidade, com o objetivo de satisfazer ao cliente final.

STRUKHART (1995) classifica os materiais que tomam parte do processo de construção como:

- matérias primas: compradas geralmente em grande volume (argamassas ensacadas, areia, cimento, madeira, etc.) e usadas principalmente na etapa da obra bruta;

- componentes (blocos, peça cerâmicas, material hidráulico, etc.);

- produtos terminados (louças e metais).

No entanto, existe uma outra classificação dos materiais de construção de interesse (ver Tabela 2):

- produtos elaborados em massa: referem-se aos produtos para os quais existe oferta constante no mercado e que podem servir para qualquer empreendimento (tijolos, cimento, componentes cerâmicos, etc.). Geralmente, provêm de processos industrializados ou semi-industrializados. Estes podem ser utilizados na etapa da obra bruta (cimento, blocos, cerâmicos, componentes hidráulicos e elétricos, etc.) como também na de acabamento (louças, metais, dobradiças, etc.).

- Produtos feitos sob pedido (costumized): estes produtos se caraterizam por serem feitos para um projeto específico (portas, esquadrias, fôrmas, "parede pronta", etc.). Muitos deles podem provir de processos artesanais. 
Esta última classificação é importante já que determina a informação básica para iniciar a compra de um produto. Os produtos feitos em massa, por exemplo, normalmente são fornecidos por distribuidores e são produtos que, indiferentemente, podem ser adquiridos de um ou outro fornecedor.

O tempo do resposta do fornecedor pode ser curto dependendo do estoque que tenha. Além disso, são produtos cujo destino no canteiro é simples (e.g. a posição de um tijolo em uma parede é indiferente). Por outro lado, pode-se dizer que grande parte deles são padronizados, ou existem marcas reconhecidas que garantem em certo grau a qualidade do produto. Isso facilita as informações necessárias para se passar ao fornecedor no momento em que se inicia a negociação.

A Tabela 2 apresenta os fornecedores destes tipos de produtos divididos em dois grupos (ambos do tipo 1): os que fornecem materiais para a obra bruta e os que fornecem materiais prontos a serem empregados na etapa de acabamento. É importante ressaltar que apesar destes produtos normalmente estarem disponíveis no mercado deve-se programar sua compra com antecipação, já que na maioria das vezes os pedidos são grandes, e o fornecedor deve se programar para atendê-los.

Já no caso dos produtos feitos sob pedido, os fornecedores são normalmente os fabricantes e o destino no canteiro é específico. Isto quer dizer cada um destes elementos vai ter um lugar específico na obra (e.g. na entrega do aço cortado e dobrado indica-se claramente o elemento estrutural ao qual se destina). As especificações e os projetos para produção tornam-se um elemento de extrema importância para conseguir se transmitir ao fornecedor as características do produto requerido o mais claramente possível. A encomenda deve ser feita com a antecipação necessária, já que os produtos são fabricados sob pedido. 
Tabela 2.- Classificação das empresas fornecedoras segundo as características do produto fornecido

\begin{tabular}{|c|c|c|c|}
\hline & \multicolumn{2}{|c|}{ Tipo 1} & Tipo 2 \\
\hline Caraterísticas & \multicolumn{2}{|c|}{ Produção em massa } & Customized (sob pedido) \\
\hline $\begin{array}{c}\text { Tipo de } \\
\text { fornecedor }\end{array}$ & \multicolumn{2}{|c|}{ Distribuidor, produtor } & Produtor \\
\hline $\begin{array}{l}\text { Destino no } \\
\text { canteiro }\end{array}$ & \multicolumn{2}{|c|}{ Simples } & Específico \\
\hline \multirow[b]{2}{*}{$\begin{array}{l}\text { Tipo de } \\
\text { produto }\end{array}$} & $\begin{array}{c}\text { Matérias primas e } \\
\text { componentes }\end{array}$ & Produtos Terminados & Sub-sistemas \\
\hline & $\begin{array}{l}\text { Argamassa, cimento, } \\
\text { cal, aço, blocos, } \\
\text { cerâmicos, material } \\
\text { elétrico e sanitário }\end{array}$ & Louças e metais & $\begin{array}{c}\text { Fôrmas, elevadores, esquadrias, } \\
\text { portas de madeira, pisos de } \\
\text { madeira. }\end{array}$ \\
\hline $\begin{array}{l}\text { Entregas no } \\
\text { canteiro }\end{array}$ & Várias & Uma & Várias \\
\hline Etapa na obra & Obra bruta & Acabamento & Obra bruta e acabamento \\
\hline $\begin{array}{c}\text { Informações a } \\
\text { passar ao } \\
\text { fornecedor }\end{array}$ & Especificações técnicas & $\begin{array}{c}\text { Especificações de } \\
\text { desempenho e técnicas }\end{array}$ & $\begin{array}{l}\text { Projeto para produção; } \\
\text { especificações técnicas; } \\
\text { detalhes arquitetônicos. }\end{array}$ \\
\hline Comentários & $\begin{array}{l}\text { - Devido à grande } \\
\text { quantidade de } \\
\text { produtores e } \\
\text { fornecedores, a } \\
\text { qualidade do produto é } \\
\text { muito variável, sendo } \\
\text { indispensável o controle } \\
\text { no recebimento. } \\
\text { - Produto geralmente } \\
\text { difícil de quantificar, } \\
\text { pedir e controlar. }\end{array}$ & $\begin{array}{l}\text { - O produto é geralmente } \\
\text { comprado por marca, na } \\
\text { maioria dos casos existem } \\
\text { catálogos do fabricante que } \\
\text { facilitam as informações a } \\
\text { passar no momento da } \\
\text { compra. } \\
\text { - Produto fácil de } \\
\text { quantificar, pedir e } \\
\text { controlar. }\end{array}$ & $\begin{array}{l}\text { Produto difícil de pedir e } \\
\text { controlar. }\end{array}$ \\
\hline
\end{tabular}

A Tabela 2 mostra ainda claramente que os fornecedores de materiais das empresas construtoras têm características diferentes segundo o produto que fornecem. O seu tempo de resposta vai ser influenciado por estas características. Em alguns casos o fator crítico para eles será seu tempo de produção; em outros, conseguir uma demanda mínima para que a sua produção seja rentável e conseguir um preço competitivo no mercado. Outros ver-se-ão limitados por sua capacidade de produção ou estoque.

Todos estes fatores irão intervir na negociação entre a empresa construtora e a fornecedora, demostrando que os agentes da cadeia não são independentes mas dependem um do outro para conseguir trabalhar. Assim, deve-se levar estes fatores em 
conta desde a etapa do projeto, que é aquela na qual devem ser definidos os materiais a serem usados no empreendimento.

\section{Conclusões do Capítulo}

Neste capítulo pretendeu-se estabelecer o contexto de fundo no qual se desenvolveu a pesquisa. Inicialmente, discutiu-se a importância atual da logística como meio de obter vantagem competitiva através da otimização dos recursos das empresa. Destacou-se também que, na construção civil, as perdas de materiais estão em parte relacionadas a uma gestão logística deficiente.

A gestão de materiais, a qual constitui o foco desta pesquisa, foi entendida como a parte da logística que se encarrega de fazer com que os materiais estejam no lugar certo, no momento certo, com a qualidade requerida e ao menor custo. Portanto, ela se constitui em elemento fundamental para uma gestão da produção eficiente.

Discutiram-se três modelos de gestão contemporâneos, TQM, JIT e a Lean Construction. Estes modelos apontaram que para garantir a eficiência da gestão de materiais precisa-se de: planejamento confiável da produção; especificações de materiais e procedimentos de compra, execução e controle (formalização da empresa); procedimentos de seleção e avaliação de fornecedores; análise críticas de projeto e de contrato. E, além disso, que o conceito moderno da gestão de materiais procura eliminar os estoques ao longo de todo o processo e para tal se baseia em uma produção pró-ativa ("puxada").

Por último, os conceitos trazidos pela cadeia de suprimentos reforçam a importância da relação comprador \& fornecedor e colocam o bom desenvolvimento desta relação como condicionante para o sucesso da gestão de materiais. 


\section{Capítulo 3 A Informação no In terior da Organização}

Sendo a comunicação um elemento de vital importância para uma gestão eficiente de materiais, este capítulo se inicia definindo alguns conceitos básicos da área da informação, quais sejam: dados, informação e comunicação. Com estes conceitos discute-se a importância da informação na organização, especificamente no processo de tomada de decisões, essencial à gestão de materiais.

A importância deste capítulo reside no fato de que os temas aqui discutidos servirão para identificar os parâmetros que serão levados em conta na análise dos sistemas de informação nas empresas estudadas.

\subsection{Conceitos Básicos}

\subsubsection{Informação}

BARTON et al. (1985) vinculam o conceito de informação aos fatos, dados e conhecimentos. Segundo eles fato é algo que tenha acontecido e sido verificado enquanto que dados são fatos obtidos de pesquisas empíricas ou observações. Já os conhecimentos representam os fatos ou dados recolhidos de distintas formas e armazenados para referência futura.

Por outro lado, vários autores definem a informação como o resultado do tratamento de dados (BIO, 1985; BURCH et al., 1979). Já DAVIS; OLSON (1985) acrescentam que "a informação são os dados que foram processados de forma que tenham significado para o seu receptor, possuindo valor real para decisões atuais ou futuras".

Portanto, o propósito da informação é incrementar o nível de conhecimento para quem a recebe e tem valor tanto para uma decisão específica quanto para decisões futuras. Em um processo decisório, reduz a variedade das escolhas e a incerteza relativa a estas escolhas. 
Como já foi comentado a informação é resultado de um processamento de dados. BURCH et al. (1979) identificam dez operações que convertem dados em informação, quais sejam: captura; verificação; ordenamento; condensamento; cálculo; armazenamento; recuperação; reprodução; disseminação; e comunicação. Qualquer destas operações ou combinação delas podem transformar dados em informação.

Por outro lado, para que a informação seja realmente efetiva e tenha valor é necessário que possua alguns atributos. Sendo assim, tem-se que os principais atributos da informação são: acessibilidade; compreensão; precisão; adequação; oportunidade; clareza; flexibilidade (adaptável a vários usuários); "verificabilidade”; livre de alterações, entre outras.

\subsubsection{Comunicação}

BARTON et al. (1985) relacionam a comunicação com o intercâmbio de pensamentos ou opiniões através de palavras, senhas ou meios similares. THOMAS et al. (1998) agregam que a comunicação é um processo no qual se estabelece uma troca de entendimento entre duas ou mais pessoas. Compartindo esta opinião, GOETSCH; DAVIS (1994) definem comunicação como a transmissão de uma mensagem que é tanto recebida como compreendida.

Destas últimas definições pode-se observar que para que exista comunicação deve-se dar não somente a troca de informações mas também é importante que estas informações sejam entendidas com o significado intencional da fonte. 


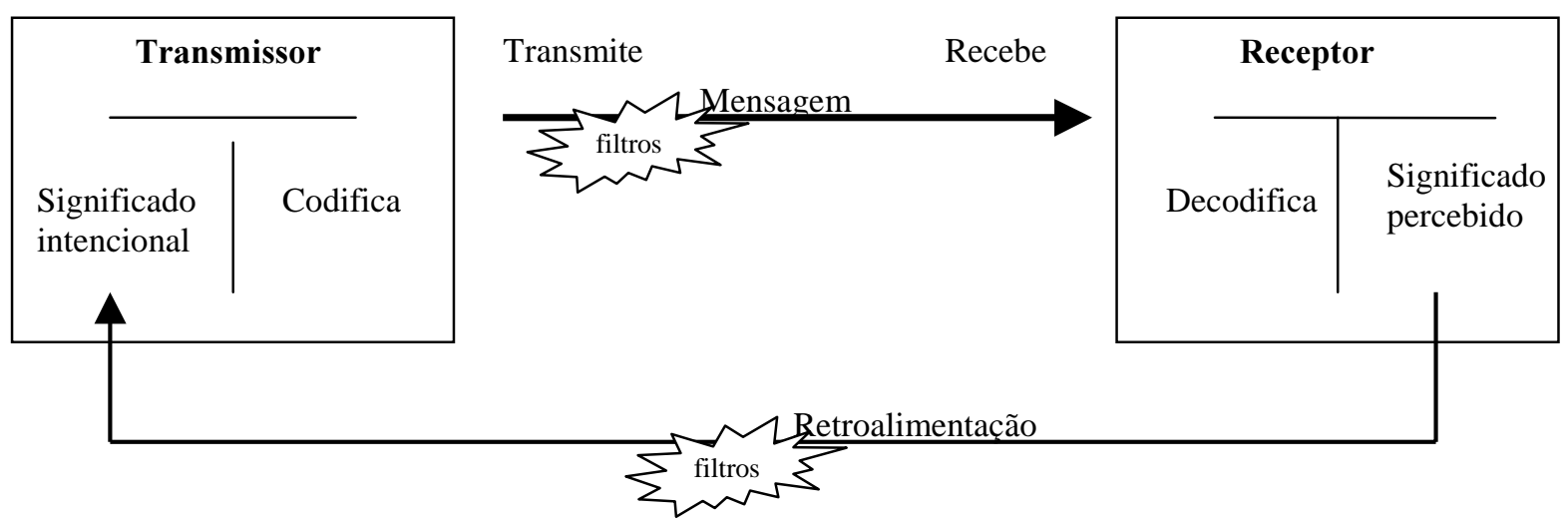

Figura 2.- O Processo de Comunicação (SCHERMERHORN et al., 1994)

A Figura 2 representa este processo e seus elementos, quais sejam:

- Transmissor: é quem origina a comunicação e codifica a mensagem a ser enviada.

- Receptor: é a pessoa o grupo de pessoas para quem a mensagem está dirigida.

- Mensagem: é a informação ou idéia que pretende ser transmitida, compreendida e aceita.

- Canais: são os condutos por onde a informação circula. Podem ser formais ou informais. Os formais são os que seguem os caminhos organizacionais, enquanto que os informais não seguem nenhuma estrutura predeterminada. Os canais formais normalmente são verticais e tendem a ser diretivos, mas também são usados para manter a direção da empresa informada do estado das atividades, processos e projetos que acontecem na empresa. Já os canais informais podem ser diagonais ou laterais e surgem espontaneamente a partir das relações de amizade ou antagonismo entre as pessoas da empresa.

- Meios: os meios são freqüentemente dados pelo canal. THOMAS et al. (1998) os classificam como hard e soft. Os primeiros, hard, incluem contratos, procedimentos, planos, relatórios, regulamentações. Estes normalmente têm uma estrutura, controle formalizado, são gerados pelo sistema e utilizam canais formais. Por outro lado, os meios de comunicação soft são geralmente menos estruturados, verbais e informais. 
- Filtros ou barreiras: são aspectos do sistema de comunicação que limitam o fluxo de informações durante a transmissão. Segundo SCHERMERHORN et al. (1994) estes podem ser causados por: distrações físicas; problemas semânticos; diferenças culturais; ausência de retroalimentação ou a própria estrutura organizacional.

- Retroalimentação: este elemento é essencial para completar adequadamente o processo de comunicação. A retroalimentação confirma se a mensagem foi corretamente compreendida.

\subsubsection{Comunicação Eficaz e Eficiente}

Segundo SCHERMERHORN et al.(1994), a comunicação eficaz ocorre quando a mensagem intencional do transmissor e a do receptor é única e coincidem. GOETSCH; DAVIS (1994) agregam que a comunicação eficaz significa que a mensagem é recebida, compreendida e produz uma ação da maneira como foi pensada pelo transmissor. Por outro lado, a comunicação eficiente acontece quando o processo se estabelece com o mínimo custo de recursos (e.g. tempo).

Uma comunicação eficiente não é necessariamente eficaz e similarmente uma comunicação eficaz não é sempre eficiente. Ao otimizar um sistema de informações procura-se com que a comunicação estabelecida seja tanto eficiente quanto eficaz.

Já tendo definidos os principais conceitos referentes a informação, a seguir discute-se a relação entre a estrutura organizacional e seus fluxos de informações.

\subsection{A estrutura organizacional e seus fluxos de informações}

Antes de definir estrutura organizacional começa-se por entender o que sejam as organizações. ETZIONI(1964) as define como "unidades sociais formadas deliberadamente para atingir objetivos específicos". Complementando esta definição BURTON; OBEL (1995) colocam que além de ser unidades sociais (formadas por 
indivíduos) estas têm atividades e limites. Portanto, as organizações são um agrupamento de indivíduos, com limites preestabelecidos, desenhadas para cumprir objetivos.

Já VIVANCOS (2000) define estrutura organizacional como "a forma como são agrupados e coordenados os recursos (humanos, fisicos e financeiros) com o intuito de se atingirem os objetivos da organização”.

CHANDLER (1962) destaca que esta estrutura apresenta dois aspectos: (i) as linhas de autoridade e de comunicação entre as diferentes unidades e seus ocupantes; (ii) a informação e os dados que fluem através dessas linhas. Sendo estes dois aspectos essenciais para garantir eficazmente a coordenação, avaliação e planejamento necessários à condução das metas da empresa.

Esta última definição vincula a estrutura organizacional com a comunicação dentro da organização e destaca a importância desta última como mecanismo de coordenação, sem o qual a organização seria um conjunto de atividades isoladas. Portanto, uma organização processa informação para controlar e coordenar suas atividades. Através do processamento de informações, observa o que acontece, analisa-se, toma-se decisões e as comunica aos funcionários (BURTON; OBEL, 1995).

A forma da estrutura organizacional geralmente determina os fluxos de informação na empresa, mas também uma mudança nos fluxos de informação podem fazer com que a estrutura da empresa mude (GALBRAITH, 1974). Esta última colocação é interessante porque mostra que é possível intervir na estrutura organizacional de uma empresa a partir da intervenção nos seus fluxos de informações. 
Por outro lado, as estruturas organizacionais podem variar em: configuração, grau de complexidade, grau de formalização e grau de centralização, sendo que todas estas características afetam os fluxos de informações dentro da organização.

As principais formas de configurações ou departamentalizações que pode adotar uma organização são: funcional, geográfica, por produtos ou serviços, por fases do processo de produção, por clientes, por projetos, matricial, por centros de lucros e celular (CHIAVENATO, 1997; MINTZBERG, 1995, VIVANCOS, 2000). Nem sempre estas estruturas aparecem puras, a maioria das empresas apresentam uma combinação delas.

Grande parte das empresas construtoras do setor edificações no Brasil apresentam estrutura do tipo funcional (VIVANCOS; CARDOSO, 2000). Nos estudos de caso apresentados no Capítulo 5, por exemplo, as três empresas estudadas apresentam uma estrutura basicamente funcional mas com certo grau de estrutura por projetos.

A complexidade se refere ao grau de diferenciação horizontal, vertical ou espacial da organização. O grau de diferenciação horizontal diz respeito à especialização dentro da empresa. Já o vertical é dado pelo número de níveis hierárquicos entre a alta gerência e o nível mais baixo. Por último a diferenciação espacial mede a dispersão geográfica das atividades na organização.

A medida que o grau de complexidade em uma organização aumenta, seus requisitos de coordenação e processamento de informação também se incrementam (BURTON; OBEL, 1995).

A formalização é uma forma pela qual as organizações podem conseguir um comportamento padronizado como meio de coordenação e controle. A formalização representa as regras na organização. HALL (1972) afirma que a formalização se mede 
através do número de regras escritas. Geralmente, quanto maior a quantidade de regras escritas maior a formalização.

Segundo BURTON; OBEL (1995), a formalização pode ser entendida tanto como uma forma de incrementar a capacidade de processamento de informações quanto como um meio de diminuir a demanda pelo processamento de informação. As regras e os procedimentos padronizados fazem com que o processamento de informações possa ser realizado por hierarquias de níveis inferiores. Por outro lado, a formalização diminui a quantidade de informação que deve ser processada para cada produto e cliente.

Embora a maioria das empresas do setor da construção de edifícios não tenha uma estrutura formalizada, hoje em dia, o movimento da gestão da qualidade está fazendo com que as empresas construtoras comecem a pensarem na formalização como meio de controle de suas atividades (VIVANCOS; CARDOSO, 2000). O número crescente de empresas implementando programas de gestão de qualidade é um indicador de que a formalização está crescendo no setor.

Por último, a centralização está relacionada com quem toma as decisões. Para MINTZBERG (1995) uma estrutura organizacional é centralizada quando o poder para a tomada decisões resta em um só local da organização. A medida que o poder fica disperso entre muitas pessoas, pode-se chamar a estrutura de descentralizada.

O elemento essencial da descentralização é a liberdade de escolha. Pode trazer como benefícios: (i) a otimização na toma de decisões, já que um gerente de uma sub-unidade está em melhor posição para reagir às condições e informações locais; (ii) maior incentivo devido à possibilidade de reagir aos fatores que afetam objetivos pessoais; (iii) reduz o escopo do controle; (iv) traz consigo uma distribuição mais homogênea da tomada decisões. Mas também pode trazer desvantagens: (i) falta de coordenação e 
informação entre os departamentos envolvidos; (ii) maior custo pela exigência de melhor seleção e treinamento dos administradores médios; (iii) risco de subjetivação (os gerentes podem defender mais os objetivos departamentais que os empresariais); (iv) as políticas e procedimentos podem variar enormemente nos diversos departamentos (CHIAVENATO, 1997).

Embora hoje em dia exista uma tendência por parte das empresas para a descentralização, não existe uma resposta única para todas as organizações. O principio de gestão, o porte, a complexidade, o ambiente, entre outros, são fatores que determinaram um arranjo único de condições para cada empresa e determinaram o grau de centralização mais adequado para cada caso.

No caso das empresas construtoras do subsetor de edificações no Brasil, por exemplo, a maioria delas apresenta uma estrutura centralizada (VIVANCOS, 2000).

Por outro lado, existem fatores que podem influenciar na forma da estrutura de uma organização e nas caraterísticas anteriormente descritas, quais sejam: sua filosofia de gestão, seu porte, o ambiente, sua tecnologia e sua estratégia.

Para BURTON; OBEL (1995) a filosofia de gestão está relacionada com as seguintes características da organização: grau de delegação; grau de detalhe para a tomada de decisões; se a tomada de decisões é reativa ou pró-ativa; grau de risco assumido; motivação; e controle. Desta forma, pode-se observar que os graus de delegação, motivação e controle estão altamente ligado ao grau de centralização da organização. Por outro lado, o planejamento e o controle podem estar relacionados com a formalização.

É importante relacionar o porte de uma organização não somente com o número de pessoas que nela atuam, mas também com o nível de profissionalização destes 
funcionários. A capacidade de processamento de informações da organização vai depender do tipo de funcionários que nela trabalham (BURTON; OBEL,1995).

A Tabela 3 mostra a relação entre o porte da empresa dependendo do número de funcionários é do grau de profissionalização destes para EUA.

Tabela 3.- Porte da empresa segundo o nível de funcionários e a profissionalização para EUA (BURTON; OBEL,1995)

\begin{tabular}{|c|c|c|c|c|c|}
\hline \multirow{2}{*}{ Porte } & \multicolumn{5}{|c|}{$\begin{array}{c}\text { Profissionalização (proporção de funcionários profissionais ou com } \\
\text { anos de especialização ou treinamento) }\end{array}$} \\
\cline { 2 - 6 } & $\mathbf{0 - 1 0 \%}$ & $\mathbf{1 1 - 2 0 \%}$ & $\mathbf{2 1 - 5 0 \%}$ & $\mathbf{5 1 - 7 5 \%}$ & $\mathbf{7 6 - 1 0 0 \%}$ \\
\hline Pequena & $<100$ & $<50$ & $<33$ & $<25$ & $<20$ \\
\hline $\begin{array}{c}\text { Média com } \\
\text { baixo impacto }\end{array}$ & $101-500$ & $51-250$ & $34-166$ & $26-125$ & $21-100$ \\
\hline Média & $505-1000$ & $251-500$ & $167-333$ & $126-250$ & $101-200$ \\
\hline $\begin{array}{c}\text { Grande com } \\
\text { baixo impacto }\end{array}$ & $1001-2000$ & $\begin{array}{c}501- \\
1000\end{array}$ & $334-666$ & $251-500$ & $201-400$ \\
\hline Grande & $2001<$ & $1001<$ & $667<$ & $501<$ & $401<$ \\
\hline
\end{tabular}

Estes mesmos autores acrescentam que quanto maior o grau de profissionalização maior a possibilidade de descentralização e maior a possibilidade de coordenação através de mecanismos formalizados. O porte incrementa a demanda de processamento da informação na empresa. Como conseqüência a necessidade de coordenação aumenta, o que influencia na estrutura do fluxo de informações.

A maioria das empresas construtoras do subsetor edificações varia entre pequeno a médio porte e, ainda mais, grande parte das de médio porte se iniciaram como pequenas, com um único dono. Isso explica porque a maioria delas são centralizadas.

O ambiente é outro fator condicionante da estrutura organizacional. A medida que a incerteza e a complexidade do ambiente cresce, a demanda por processamento de informação na organização também se incrementa. Portanto, a organização deve se estruturar para conseguir superar este fator. 
A tecnologia também influencia a estrutura organizacional. Segundo seja o tipo da tecnologia que utiliza a empresa varia sua demanda de informação e, portanto, a empresa deverá tratar de se organizar para adaptar sua capacidade de processamento de informações para cumprir com a demanda existente. Existem várias classificações da tecnologia mas para este trabalho utiliza-se a realizada por SCOTT (1992) ${ }^{9}$ apud BURTON; OBEL (1995) por ser a mais adequada para descrever as tecnologias utilizadas no processo construtivo. Ele descreve a tecnologia através de três dimensões:

- complexidade, diversidade: número de diferentes itens requerendo considerações simultâneas;

- incerteza, imprevisibilidade: grau em que o trabalho pode ser previsto com antecipação;

- interdependência: a mudança em um item implica a mudança nos outros itens?

Quanto maior a variabilidade destas três dimensões maior será a demanda de informação. A tecnologia utilizada na construção de edifícios é bastante diversa e tem um alto grau de interdependência e, além disso, o produto se caracteriza por ter um alto grau de incerteza. Todos estes fatores fazem com que a demanda por processamento de informações seja muito elevada e, portanto, é difícil fazer com que a capacidade de processamento consiga satisfazer esta demanda.

Por ultimo, quanto à estratégia, BURTON; OBEL (1995) afirmam que a estrutura vai depender do perfil da organização, quanto à sua estratégia. Para entender o como a estratégia influencia na estrutura organizacional utiliza-se as tipologias organizacionais

${ }^{9}$ SCOTT, W R. Organizations: Rational, Natural and Open Systems. Englewood Cliffs, NJ: PrenticeHall. 1992. 
propostas por MILES; SNOW (1986), quais sejam: prospectivas, defensivas e analíticas $^{10}$.

As primeiras, prospectivas, são as que aparecem no mercado com um novo produto ou serviço e se diferenciam de seus competidores usando sua habilidade para desenvolver tecnologias e produtos inovadores. Já as segundas, defensivas, oferecem uma linha de produtos estável e limitada e sua estratégia competitiva está baseada normalmente no custo. Por último, as analíticas operam em dois domínios de mercado, um relativamente estável e o outro variável. Em suas áreas estáveis, eles operam rotineiramente através do uso de estruturas e processo formalizados. Por outro lado, em suas áreas variáveis, analisam seus competidores e adotam as idéias que aparecem como mais prometedoras (MILES; SNOW, 1986).

Cada uma destas tipologias, além de indicar a orientação estratégica, também especifica as principais características organizacionais requeridas para suportar estas estratégias. Assim, as defensivas dependem de uma estrutura funcional com tomada de decisões centralizada, comunicação e integração vertical com altos graus de especialização técnica. Por outro lado, as prospectivas utilizam estruturas mais flexíveis, como uma divisão por produto nas quais o planejamento e o controle são altamente decentralizadas. Por último, as analíticas empregam estruturas mistas, como a matricial.

Até aqui tem-se discutido como fatores inerentes ou externos à organização afetam e determinam as caraterísticas de sua estrutura organizacional (configuração, centralização, formalização e complexidade) e como estas características determinam os fluxos de informações dentro da organização. A seguir discute-se a importância da informação na tomada de decisões.

\footnotetext{
${ }^{10}$ Traduzidas do inglês: prospectors, defenders e analysers, respectivamente.
} 


\subsubsection{A importância da informação no processo de tomada de decisões}

Cada indivíduo ou grupo de uma organização precisa da informação de outros indivíduos ou grupos para poder exercer seu trabalho corretamente. A informação suporta o planejamento, controle e a tomada de decisões na organização.

A importância de se fornecer informação oportuna e apropriada é indispensável para tomar uma decisão adequada. De acordo com BURCH et al. (1979), este processo pode variar entre decisões simples ou rotineiras até outras complexas com alto grau de impacto na empresa. Neste sentido, SIMON (1960) distingue entre decisões que podem ser programáveis e outras não programáveis. As primeiras, programáveis, referem-se àquelas para as quais uma resposta automática é dada por regras previamente estabelecidas, como é o caso de problemas repetidos e rotineiros; quanto às segundas, não programáveis, são aquelas onde somente uma parte de seus parâmetros são conhecidos e muitos de seus parâmetros conhecidos são probabilísticos (BURCH et al., 1979).

Portanto, quando analisar um sistema de informação em uma empresa é importante tratar de identificar e reconhecer as decisões que podem ser programáveis, para se implementar uma rotina sempre que for possível. Já para a outra classe de decisões, o sistema deve prover a informação necessária para que a pessoa que tome a decisão tenha a informação suficiente para escolher a decisão correta.

Ao analisar-se uma empresa, tem-se que em todos os seus níveis hierárquicos os funcionários necessitam tomar decisões constantemente para fazer com que ela funcione. No entanto, as decisões em cada nível têm um impacto e uma transcendência diferente na empresa.

BURCH et al. (1979) caraterizam as decisões segundo o nível hierárquico (Figura 3): 
- estratégico: as decisões neste nível são caracterizadas por uma grande quantidade de incerteza e normalmente decidem o futuro da organização. Portanto, afetam a empresa como um todo. As decisões nesse nível não são programáveis.

- Tático: já neste nível as decisões têm transcendência a curto prazo, e normalmente prevêem atividades ou locação de recursos para o cumprimento de objetivos (ex. orçamentação; escolha do layout; melhoria do produto; etc.). Neste nível, as decisões subsidiam tanto o planejamento quanto o controle. As decisões neste nível têm pouco potencial para ser programadas.

- Operacional: o processo de tomada de decisões neste nível tem com objetivo assegurar que tarefas específicas sejam implementadas de forma eficiente e eficaz. Neste caso, as decisões tomadas irão subsidiar o controle e as decisões têm um alto potencial para ser programadas.

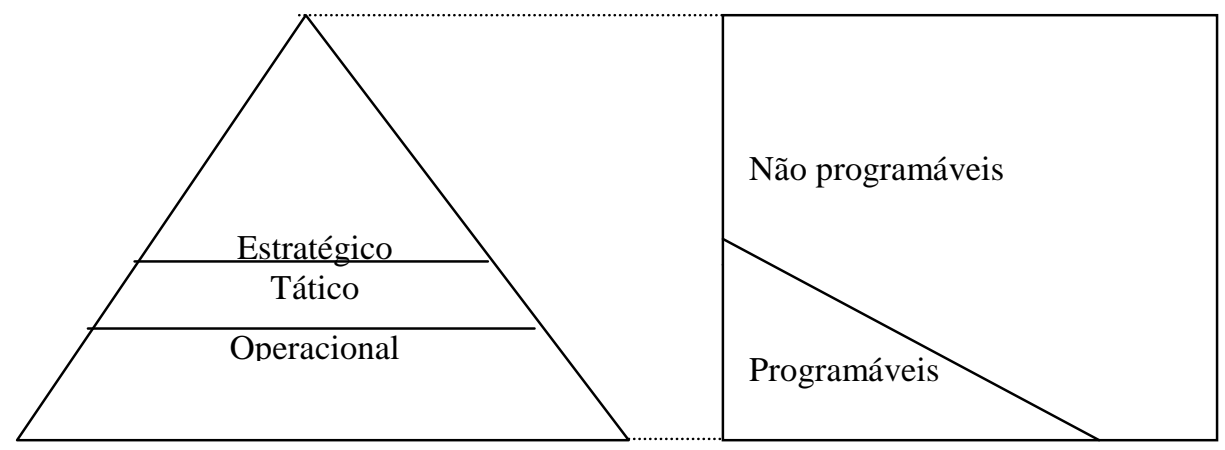

Figura 3.- Grau no qual o processo as decisões podem ser programado ou não programado (BURCH et al., 1979)

Um fator importante que influencia na quantidade de informação necessária para a tomada eficaz de decisões é a incerteza. GALBRAITH (1974) afirma que "quanto maior a incerteza na tarefa, maior a quantidade de informação que deve ser processada durante a execução desta pelas pessoas que tomam as decisões para conseguir um dado nível de desempenho”. 
Assim, uma consequiência da incerteza é a de limitar a habilidade de uma organização em planejar ou tomar decisões acerca de atividades futuras. Os eventos não programados são os que colocam a maior carga informativa na organização. A medida que a incerteza aumenta a empresa precisa incrementar sua capacidade de processamento de informações através de mecanismos de integração.

GALBRAITH (1974) coloca que a integração pode ser obtida por três mecanismos:

- coordenação por regras e programas: este é o caso quando as decisões são simples e programáveis e podem se estabelecer regras ou rotinas.

- Coordenação por hierarquia: a medida que a organização enfrenta maior grau de incerteza, seus participantes enfrentam situações pelas quais não existem regras pré estabelecidas. Nestes casos, os funcionários de hierarquias mais elevadas são chamados a resolver as situações. No entanto, esta situação tem um limite, a medida que a incerteza incrementa as exceções aumentam, criando-se assim uma saturação nos níveis altos de hierarquia.

- Coordenação através de objetivo e metas: neste caso, a organização opta por estabelecer metas a serem alcançadas. Desta forma, os funcionários decidem o caminho para obter os resultados. Assim sendo, o planejamento diminui a quantidade de informações processadas nos níveis hierárquicos elevados, aumentando o poder de decisão em níveis menores. Igualmente, o planejamento reduz a necessidade de comunicação entre unidades interdependentes sempre e quando a tarefa estiver dentro do planejado. Para as exceções novamente os níveis hierárquicos elevados são chamados a decidir.

A idéia é que a organização possa processar suas informações através da combinação destes três mecanismos, conseguindo, assim, coincidir sua capacidade de processar 
informações com a demanda existente por informações. Quando a demanda por informações supera a capacidade de processar informações, a organização deverá se redesenhar para cumprir com a nova exigência. Para tal, existem duas opções: (i) diminuir a necessidade de processar informações; (ii) aumentar a capacidade de processar informações (GALBRAITH, 1974).

Este mesmo autor estabelece dois métodos para alcançar cada uma das opções:

i) Diminuir a necessidade de processar informações:

(ia) criação de metas ou recursos com margens: consiste em incrementar as metas para diminuir a quantidade de exceções que são as que saturam as hierarquias superiores. Por exemplo, pode-se aumentar a montante do orçamento, os estoques, os prazos, etc.

(ib) Criação de grupos auto-contidos: neste caso a idéia é a de formar grupos na empresa que estejam destinados a um produto específico; cada grupo deverá ter seus próprios recursos para cumprir com suas metas. Por exemplo, passar de uma estrutura organizacional funcional a uma por produto. Dependendo do caso, existem funções que devem se manter comuns para toda a organização, que geralmente são as funções que têm economias de escala.

\section{ii) Aumentar a capacidade de processamento de informações:}

(ia) investimento em sistemas de informação verticalizados: neste caso a capacidade é aumentada com uso de computadores e sistemas de informação.

(ib) Criação de relações laterais: este método consiste em empregar processos de decisões que cortem as linhas de autoridade. A idéia é a de mover o nível onde se efetua a decisões para o lugar onde existe a informação, mas sem reorganizar a estrutura em torno de grupos. Existem vários tipos de processos de decisão lateral, quais sejam: contato direto, times, organização matricial, etc. 
Atualmente a proliferação e desenvolvimento das novas tecnologias de informação como as redes, multimídia, Internet fazem com que as estratégias estabelecidas por Galbraith em 1974 devam ser atualizadas. A velocidade e a quantidade de informação que pode ser processada e trocada por estes novos meios de comunicação, além da acessibilidade destas tecnologias, deve ser levada em conta.

Isso faz com que, hoje em dia, o uso das tecnologias da informação seja a forma mais disseminada para incrementar a capacidade de processamento de informações em uma organização. As novas tecnologias de informação permitem realizar vários processos sem precisar das pessoas que antigamente processavam as informações. Além disso, as comunicações se realizam de uma maneira mais rápida, muitas vezes quebram hierarquias e permitem a existência de uma estrutura organizacional informal que agiliza a tomada de decisões na empresa.

Por último, é importante notar que cada um destes métodos formulados por GALBRAITH (1974) tem um custo associado. A organização deverá portanto optar por um deles ou uma combinação deles que represente o menor custo. É importante que a empresa faça uma escolha estudada já que do contrário o primeiro método será o naturalmente eleito.

\section{Conclusões do Capítulo}

Em resumo, neste capítulo discutiu a importância da informação dentro da organização como meio de coordenação e controle de suas atividades.

Para tal, apresentaram-se as características da estrutura organizacional, quais sejam: centralização, formalização, complexidade e configuração e a sua relação com os fluxos de informações dentro da organização. Além disso, explicou-se como fatores inerentes e externos à organização, como são a filosofia de gestão, a estratégia, a tecnologia, o porte 
e o ambiente influenciam estas características. Cada organização deverá, portanto, tratar de conseguir uma harmonia entre estes fatores e as características de sua estrutura organizacional para conseguir otimizar suas atividades.

Adicionalmente foi estudado o processo da tomada de decisões e identificou-se dois tipos dois tipos de decisões: as que podem ser programadas por ser rotineiras e as que não podem ser programadas. Estas últimas geralmente correspondem a decisões do tipo estratégico.

Um fator que aumenta a quantidade de informação a ser processada para tomada de decisões é a incerteza, que limita a habilidade de planejamento de uma organização. Os mecanismos de integração auxiliam a empresa a lidar com a incerteza.

Por último, foi entendido que a empresa sempre vai fazer com que a demanda por processamento de informações coincida com sua capacidade de processamento. Isso pode ser obtido de duas formas, diminuindo a sua necessidade de processamento de informações ou aumentando sua capacidade de processamento das mesmas. 


\section{Capítulo 4 A Tecnologia da In formação (TI)}

Nos capítulos anteriores, discutiu-se amplamente a importância da informação como meio de coordenação e controle dentro da empresa. A tecnologia da informação - TI apresenta-se, assim, como uma possível resposta a esta demanda por coordenação e comunicação e além disso como uma forma de aumentar a capacidade de processamento de informações na organização. Sua importância é flagrante nestes dias onde as novas exigências do setor fazem com que a demanda processamento de informações nas empresas seja cada vez maior.

LUCAS (1997) define a TI como todas as formas de tecnologia aplicadas ao processamento, guarda e transmissão de informações eletronicamente. O equipamento físico usado para este propósito inclui os computadores, equipamento para comunicação, redes, faxes, etc.

Atualmente, a oferta destes produtos no mercado é cada vez maior e seus custos são cada vez menores. Sendo assim, existe uma tendência crescente por parte das indústrias de incorporar a TI tanto nos seus processos de produção quanto em seus produtos. Além disso, o potencial da TI já não está sendo simplesmente focado na sua capacidade para estocar e processar dados, mas, principalmente, como um meio eficaz de comunicação.

Desde há mais dez anos fala-se da revolução que a TI vem causando na forma de fazer negócios (PORTER; MILLAR, 1985; Mc FARLAN, 1984), aspecto que, inclusive, já é discutido no caso da construção civil (CLARK et al., 1999). Para estes autores, a tecnologia da informação vem modificando tanto a forma como as empresas competem quanto a estrutura das indústrias e até desenvolvendo novos negócios. A TI se tornou desta maneira em uma forma de adquirir vantagem competitiva. 
GIBSON; HAMMER ${ }^{11}$ apud OBRIEN; AL-SOUFI (1993) apresentam na Figura 4 uma matriz na qual ressaltam os diversos estágios que se pode atingir através do uso da tecnologia da informação.

\begin{tabular}{|c|c|c|c|c|}
\hline & & \multicolumn{3}{|c|}{ Beneficiário } \\
\hline & & Indivíduo & Função ou Processo & Organização \\
\hline \multirow{3}{*}{$\frac{\mathscr{0}}{\stackrel{0}{0}}$} & Eficiência & $\begin{array}{c}\text { Mecanização da } \\
\text { tarefa }\end{array}$ & $\begin{array}{c}\text { Automatização do } \\
\text { processo }\end{array}$ & Extensão dos limites \\
\hline & Eficácia & Melhoria do trabalho & Melhoria funcional & Melhoria do serviço \\
\hline & Transformação & Expansão do papel & $\begin{array}{l}\text { Redefinição } \\
\text { funcional }\end{array}$ & Inovação do produto \\
\hline
\end{tabular}

Figura 4.- Matriz benefício / beneficiário (GIBSON; HAMMER apud O'BRIEN; AL-SOUFI, 1993)

Percebe-se, assim, que os benefícios da TI abrangem desde a mecanização da tarefa até a inovação do produto. Quanto ao seu impacto, ele varia do individual ao organizacional.

É importante também destacar que não basta investir em TI para obter as vantagens que proporciona o uso desta tecnologia. HENDERSON; VENKATRAMAN (1993) afirmam que para atingir este objetivo, a TI deve ser "explodida funcionalmente sobre uma base contínua”, o que requer de uma mudança substancial na concepção da alta gerência do seu papel na organização, assim como do entendimento dos componentes críticos da estratégia da TI e de seu papel no suporte e na formulação das decisões estratégicas na empresa.

\subsubsection{Classificação da Tecnologia da Informação}

AHMAD et al. (1995) classificam esta tecnologia em três grandes categorias:

- comunicação (networks, e-mail, fax, telefones, telecomunicações, rádios);

${ }^{11}$ GIBSON, C.; HAMMER, M. Now that the dust has settled, a clear view of the terrain. Indications,v 2, 1985. 
- acessibilidade aos dados (base de dados comuns, Electronic Data Interchange EDI, Internet, códigos de barras);

- $\quad$ sistemas de processamento de dados (expert systems, MRP, SAP, etc.).

Esta classificação está baseada na utilidade da TI sob a perspectiva do usuário. Na construção, a comunicação é uma de suas funções mais importantes, mas o sucesso desta tecnologia vai depender da qualidade e acessibilidade aos dados e da eficiência e efetividade nos sistemas desenhados para os processar (AHMAD et al., 1995).

Estes mesmos autores destacam que, nas últimas décadas, outras indústrias têm incrementado significativamente o uso da TI para a melhoria de suas operações e para criar novas formas de realizar seus negócios. Por exemplo, no que se refere a sistemas de gestão, na década de sessenta surgiu o MRP (Material Requirement Planning), que inicialmente estava restrito à área de gestão de materiais mas que atualmente tem evoluído para sistemas que integram todos os processos da empresa e que são conhecidos como ERP (Enterprise Resource Planning). Destacam-se na categoria ERP os sistemas SAP (alemão), BAAN (holandês) e Oracle (americano).

Já na área de troca de dados informatizados, na década de oitenta apareceu o EDI (Electronic Data Interchange). A função principal do EDI consiste em subsidiar as transações entre a empresa e seus fornecedores ou distribuidores através de um formato padronizado, que faz com que os computadores envolvidos consigam enviar e ler as informações trocadas. Assim sendo, este sistema permite uma integração da cadeia de suprimentos.

Por último, o surgimento da Internet trouxe consigo o aparecimento de portais que oferecem informações de todo tipo e adicionalmente disponibilizou para seus usuários o comércio eletrônico que compreende a compra e venda de produtos on-line e inclusive 
disponibiliza o aluguel de softwares. Além disso, possibilita o uso da Intranet dentro das empresas e corporações, que são redes internas que interligam um grupo de usuários utilizando os protocolos da Internet.

Posto que as tecnologias mencionadas podem ter grande potencial na indústria da construção e algumas delas já estão começando a nela serem utilizadas, considera-se oportuna a descrição destas tecnologias por estarem relacionadas à gestão de materiais, tema deste trabalho.

i) MRP II (Manufacturing Resource Planning): O MRP II é um sistema informatizado para o gerenciamento de uma empresa que integra diversas de suas áreas. Para entender o conceito do MRP II começa-se definindo o seu predecessor, o MRP (Material Requirement Planning). DOBLER; BURT (1996) definem o MRP como uma técnica usada para determinar a quantidade e data de utilização de materiais usados em uma operação de manufatura. Ele surgiu na década de sessenta. ORLICK (1975) reconhece três funções principais do MRP: (i) identificar os materiais para que possam ser encomendados na quantidade e tempo corretos; (ii) avaliar as prioridades para que as encomendas sejam efetuadas em função da data de utilização do material; (iii) considerar a capacidade necessária para se completar a carga da máquina; se planejar uma carga válida ou permitir uma visão de carga futura.

Em seus primórdios o MRP foi utilizado principalmente para gerar requisições para componentes e materiais relacionados com um cronograma de demanda específico. Após, foi usado como uma técnica de programação. Passou a ser utilizado para realimentar a programação, mudando as datas, e reprogramar as requisições. 
Com o tempo, com a finalidade de que este sistema também servisse para casos em que a capacidade de produção fosse variável, foi criado um módulo de planejamento da demanda da capacidade e ligado ao modulo original do MRP. E, finalmente, estes foram ligados ao cronograma mestre de produção. Todo este sistema passou a ser identificado como "Sistema MRP de ciclo fechado".

Já o significado de um sistema MRP II é mais abrangente e surge de uma evolução do MRP. Trata-se de um plano global para o planejamento e controle de todos os recursos de uma empresa envolvendo marketing, finanças, produção e engenharia. $\mathrm{O}$ MRP II agrega duas habilidades ao Sistema MRP de ciclo fechado. Por um lado, inclui uma interface financeira que permite converter planos de produção operacional em termos financeiros. Por outro, permite fazer simulações que auxiliam nas decisões gerenciais (DOBLER; BURT, 1996).

Como já foi comentado estes sistemas têm evoluído para os chamados ERP (Enterprise Resource Planning). É importante comentar que estes sistemas são muito caros e estão restritos a empresas de grande porte e com capacidade de investimento. Isso resulta em uma desvantagem no caso de serem utilizados no subsetor edificações, onde a grande maioria das empresas construtoras é de pequeno porte.

ii) EDI - Electronic Data Interchange: de acordo com HALSALL (1996), o objetivo do EDI é o de possibilitar que dois computadores não compatíveis troquem documentos comerciais, tais como, ordens de compra ou cotações através de um formato padronizado.

STUKHART (1995) explica que é uma tecnologia da informação pela qual um arquivo eletrônico criado em um computador é transmitido e lido por outro 
computador. Este arquivo consiste em um documento que é enviado entre duas empresas de uma forma padronizada. O software de tradução converte os dados do arquivo enviado em um formato ANSI (American National Standard Institute), depois envia o arquivo neste formato e finalmente reconverte os dados tal que o formato seja reconhecível pelo receptor.

A diferença entre o EDI e o correio eletrônico é que o primeiro usa formatos padronizados para documentos entre duas ou mais empresas parceiras, o que implica que devam existir processos internos em cada uma delas que produzam estes arquivos de entrada e saída.

O EDI surgiu devido ao fato de que várias indústrias enxergaram o potencial do uso de dados formalizados para realizar transações de negócios entre empresas. Para isso acontecer, toda a informação contida nos pedidos de compras deveriam ser transmitidos de tal modo que o receptor pudesse obter a mesma informação que a que obteria através de uma ordem convencional feita em papel. Identificando esta necessidade a ANSI criou um grupo de estudo para a criação do EDI standards.

As vantagens do EDI consistem na eliminação dos trâmites feitos em papel, diminuição do processamento manual de informações e aumento da velocidade da informação (STUKHART, 1995; O’BRIEN; AL-SOUFI, 1993).

Em várias indústrias, como na indústria automotriz por exemplo, o EDI é amplamente utilizada para a comunicação entre fornecedores e a integração da cadeia de suprimentos. O EDI tem-se constituído nestas indústrias em um condicionante para a aplicação e o sucesso do Just-in-Time.

Já na indústria da construção civil o uso desta tecnologia é baixo e está restrito a algumas empresas fornecedoras. Elas estão utilizando o EDI para o intercâmbio de 
informações entre seus fornecedores, distribuidores e transportadores, mas ainda não existe comunicação com construtoras.

GRILO et al. (1996) ${ }^{12}$ apud CLARK et al. (1999) afirmam que o principal motivo pelo qual as empresas do setor não estão usando esta tecnologia é a falta de vontade destas empresas em investirem em infra-estrutura tecnológica, em uma indústria caracterizada por elevado risco no que se refere à relação da construtora com seus fornecedores. Acrescentam que em outras indústrias o fato de se ter fornecedores com grande poder de barganha tem forçado o comercio eletrônico na cadeia de suprimentos.

No entanto, diversos autores como CLARK et al. (1999), O'BRIEN; ALSOUFI (1993) acreditam que o EDI tem o potencial para mudar a estrutura da indústria da construção atuando como um mecanismo integrador, reduzindo a fragmentação que a caracteriza.

iii) E-commerce (Comercio eletrônico): o comercio eletrônico é uma TI que utiliza o computador, a Internet e o software para enviar e receber especificações, desenhos (projetos), licitações, ordens de compra e outros tipos de informações que precisam ser comunicadas aos clientes, fornecedores, funcionários ou ao público.

Os benefícios adquiridos pelo comercio eletrônico podem ser divididos em dois grupos: os benefícios para os que compram (clientes) e os benefícios para os que vendem (fornecedores). Para os primeiros, os principais benefícios são: a redução do tempo e do custo na aquisição; maior variedade de fornecedores; incremento na produtividade do comprador; e melhoria na gestão da informação. Já para os fornecedores, as vantagens principais são: aumento do número de clientes; melhoria

\footnotetext{
${ }^{12}$ GRILO, A.; BETTS, M.; MATHEUS, M. Eletronic interaction in construction: why is it not a reality. CIB W78 Workshop, Bled Slovenia, June 1996.
} 
na eficiência operacional; e apresentação de outras opções no processo de pagamento.

Este tipo de comércio está aparecendo também na indústria da construção, que realiza operações de compra e venda de produtos e serviços nesta área. A idéia é que através de um ou mais sítios (sites) se cadastrem fornecedores e empresas construtoras. Cada sítio opera como um mercado virtual, onde podem ser enviadas as propostas e fechados os contratos. Tal sistema facilita e agiliza a negociação já que em um só lugar encontra-se um conjunto dos fornecedores, o que dá ao comprador maior variedade de ofertas. Além disso, tende a eliminar o trabalho de preparação de várias solicitações de cotação, já que através desta tecnologia se prepara uma única, se escolhem os fornecedores e automaticamente a informação é enviada para todos eles por meio de uma única operação.

Embora as duas primeiras tecnologias anteriormente descritas representaram na época de seu aparecimento e ainda representam um avanço em direção à integração tanto dentro das empresas quanto na cadeia de suprimentos, ainda não se pode afirmar que conseguiram cumprir este objetivo totalmente.

Atualmente a Internet apresenta-se como uma tecnologia de comunicação e de informação rápida, acessível e econômica que está revolucionando a forma de realizar transações tanto entre as empresas quanto entre o público em geral. Devido à sua acessibilidade existe um grande potencial para proporcionar aos usuários uma forma efetiva de integrar a cadeia de suprimentos. No entanto, é importante perceber que este potencial está sendo restringido pela falta de padrões e formatos que subsidiem as trocas de informações entre as empresas.

Tomando-se como exemplo o subsetor de edificações, comprova-se que cada uma das empresas que dele tomam parte referem-se a um mesmo produto ou sistema com uma 
codificação diferente, própria a cada empresa. Isso dificulta e, em muitos casos, impossibilita uma troca efetiva de dados entre elas. Além disso, os softwares utilizados são incompatíveis, o que dificulta mais ainda a integração.

Assim sendo, existem organismos preocupados por esta carência de padrões que trabalham para desenvolver interfaces comuns para subsidiar negócios eletrônicos. A RosettaNet, por exemplo, é um organismo independente e sem fins lucrativos que se dedica ao desenvolvimento deste tipo de interfaces (ROSETTANET, 2000).

Para entender como esta carência da padrões afeta o setor, na Figura 5 a RosettaNet apresenta, por um lado, os elementos necessários para que exista um intercâmbio de informações humanas e, por outro, os que seriam necessários para um intercâmbio de informações eletrônicas.

\begin{tabular}{|c|c|}
\hline Telefone & Ecom Application \\
\hline Processo de Negócio & Ebussiness Process \\
\hline Dialogo & Processos de Interface - PIP \\
\hline Gramática & Estrutura \\
\hline Palavras & Dicionários \\
\hline Alfabeto & HTML/XML \\
\hline Som & Internet \\
\hline
\end{tabular}

Figura 5.- Paralelo entre intercâmbio de informações de negócios humano/humano e intercâmbio eletrônico sistema/sistema (Fonte ROSETTANET, 2000).

Assim, eles explicam que para estabelecer uma comunicação de negócios humana, é necessário que se troquem senhas (sons). Além disso, precisa-se de um alfabeto (código) para criar palavras. A gramática é necessária para estabelecer o dialogo que formará o processo de negócio e que será transmitido através de um instrumento (telefone).

Fazendo um paralelo com a comunicação nos negócios eletrônicos, pode-se comparar a Internet com o meio para realizar a troca de senhas, o HTML/XML com o alfabeto e as 
aplicações Ecom representariam o instrumento de transmissão. O que ainda faltaria por ser criado seriam os dicionários, a estrutura os processos de interface e o processo de negócio eletrônico (ver Figura 5, área em destaque).

Portanto, é muito importante que a indústria e organismos governamentais estejam conscientes de que sem a existência destes formatos, a integração através da Internet estará ainda limitada. Nos Estados Unidos e Canadá, assim como em alguns países europeus, existe a preocupação de criar formatos e uma linguagem comum para a troca de informações na indústria da construção desde antes do aparecimento da Internet.

Na América do Norte, por exemplo, o UniFormat e o MasterFormat são sistemas de classificação que servem para organizar informações relativas à construção. O primeiro está baseado em elementos e subsistemas. Já o segundo utiliza números e títulos para organizar as informações em um formato padronizado e seqüencial para elaborar manuais de projeto. O MasterFormat também serve para organizar dados de custo e para preencher informações de produto ou outras. Ambos os documentos são produzidos pela Construction Specifications Canada - CSC e o Construction Specifications Institute - CSI e são amplamente utilizados nesta região (CSC, 2000).

Em países europeus latinos, como a França, verifica-se uma padronização baseada no sistema de codificação da CSI. Isto vem causando problemas de adaptação de conceitos já que ainda não existe uma correlação padronizada entre a terminologia anglo-saxão e as de origem latina. Já no Brasil assim como no restante da América - Latina ainda não existem estes padrões nem uma cultura de padronização das informações.

Com estes exemplos, percebe-se que apesar de já existir organismos que estão procurando suprir esta falta de formatos para padronizar as informações de trocas no 
setor de construção civil e conseguir desta forma uma troca eficaz de informações, na maioria de países ainda resta muito que trabalhar nesse tema.

\subsubsection{A TI no subsetor edificações}

Apesar de todas as virtudes acerca da TI destacadas anteriormente, a indústria da construção civil se carateriza por seu baixo uso. Nas empresas construtoras, por exemplo, a TI é basicamente aplicada em programas contábeis e administrativos, programas de cálculo e simulações, sistemas de orçamentos, planejamento e controle de obras, sistemas $C A D$ e, ultimamente, está nelas se generalizando o uso da Internet e dos correios eletrônicos.

Os softwares utilizados nas empresas construtoras são geralmente adquiridos através de duas formas: comprados ou feitos sob pedido. Os primeiros são os que se compram prontos no mercado e são os mais utilizados por empresas de pequeno porte. Existem diversos softwares deste tipo que servem para orçar, comprar, fazer o planejamento, etc. A maioria deles são vendidos por módulos separados. Os segundos, os softwares feitos sob pedido, são desenhados de acordo com os fluxos de informações existentes na empresa o que resulta em uma vantagem na implementação do sistema. Em geral são mais caros que os anteriores, já que implicam em um estudo e entendimento preciso da forma segundo a qual a empresa trabalha.

Nestas empresas, apesar de muitas vezes existirem dados e informações úteis para diferentes departamentos, os fluxos de informação acontecem de maneira pouco eficiente e a transferência e intercâmbio de dados e informações é muito pobre. Os softwares utilizados são geralmente comprados por departamento isolados da empresa e são incompatíveis entre si, prejudicando a integração da empresa. Esta situação traz como consequiência a duplicidade, ruídos e perdas de informações e conhecimentos e, 
principalmente, leva à não consolidação de um sistema eficiente de informações que sirva para que se tenha tomadas de decisões rápidas e eficazes.

Em grande parte das empresas construtoras, verifica-se que a introdução das tecnologias da informação tem servido para mecanizar suas tarefas de forma isolada, obtendo-se, assim, uma melhoria na eficiência na condução das mesmas. Porém, existem outras empresas, nas quais o uso da TI não está restrito unicamente à mecanização das tarefas mas também utilizam-se redes que integram funcionalmente os seus departamentos. Nestes casos, o beneficio alcançado pela introdução da TI nos processos não atingem somente a eficiência mas também a eficácia dos mesmos (ver Figura 4).

Quanto ao uso da TI nas empresas fornecedoras de materiais, o panorama é muito heterogêneo. As empresas que produzem produtos industrializados, que na maioria dos casos são de médio a grande porte, e têm capacidade de investimento, estão utilizando a TI tanto como meio tanto para integrar diversas de suas áreas quanto no interior de seus processos. Já nas empresas menores com pouca capacidade de investimento o uso desta tecnologia é mínimo ou bastante pontual.

O que está acontecendo no setor é que a maioria das empresas está introduzindo a TI inicialmente como meio de automatizar suas tarefas. A disseminação da TI em seus processos dependerá da capacidade das empresas em visualizarem a TI como criadora de benefícios sistêmicos (modificadora de processos, aumento da eficácia) e também da capacidade da empresa em realizar os investimentos necessários para isso acontecer.

Embora o panorama atual da TI dentro do subsetor de edificações é ainda relativamente inexpressivo, existe a expectativa de que, em um futuro próximo, a Internet consiga mudar esta situação. O aparecimento de aplicações e serviços para subsidiar negócios eletrônicos através da Internet, que não somente inclui comércio eletrônico de produtos 
mas que também a oferta de aplicações como é o caso do aluguel de softwares, deve propiciar que as empresas do setor comecem a utilizar a estes novos meios de forma intensiva.

O comercio eletrônico de produtos para a construção, por exemplo, já é uma realidade em nosso meio. No Brasil, existem vários portais que disponibilizam este tipo de transações e que além disso oferecem informações técnicas e outras informações úteis para as empresas do setor, quais sejam: Tapume, NaObra, Superobra, etc. Já o aluguel de softwares através da Internet ainda está em uma etapa inicial.

As aplicações (softwares) que se encontram atualmente disponíveis na Internet são maioritariamente na área de projetos. Estes softwares são geralmente de coordenação e oferecem basicamente sistemas que consolidam todas as informações referentes ao projeto em um único lugar (site). Desta forma, consegue-se uma comunicação permanente entre os agentes participantes do projeto. Adicionalmente funcionam como um organizador das atividades desta etapa e permitem que os projetistas recebam as modificações em tempo real com a conseqüente diminuição das incompatibilidades encontradas comumente nos projetos.

No entanto, para poder utilizar estes tipos de softwares os usuários têm que concordar em utilizar alguns formatos para padronizar as informações trocadas. Isso as vezes dificulta a implementação já que pressupõe uma modificação na forma como a empresa está acostumada a trabalhar.

Em resumo, neste capítulo além de se ter apresentado algumas tecnologias da informação que estão sendo utilizadas em outras indústrias para otimizar a gestão da cadeia de suprimentos, discutiu-se a importância da TI no setor como mecanismo de comunicação e coordenação. 
No entanto, para isso acontecer serão necessárias mudanças tanto no uso da tecnologia quanto na sua gestão. A padronização é um outro ponto importante que deverá ser resolvido para conseguir efetivamente integrar a cadeia de suprimentos com as novas tecnologias disponíveis. A infra-estrutura tecnológica existe, mas se encontra à espera para ser utilizada. 


\section{Capítulo 5 Método de Análise dos Fluxos de Informação}

Neste capítulo pretende-se consolidar todos os conceitos abordados nos capítulos anteriores. A idéia é a de resgatar e organizar os principais tópicos constituindo um método que sirva de guia para analisar os fluxos de informação referentes à gestão de materiais em empresas construtoras.

Diversos autores como BARTON (1985), BURCH et al.(1979) estabelecem que a análise de um sistema de informação é composta por três etapas: (i) coleta de dados e informações; (ii) caracterização dos modelos das empresas, que servirão de guia para a análise dos fluxos de informações existentes, feita a partir das informações coletadas; (iii) análise dos modelos propriamente dita. Cada uma destas etapas precisa de ferramentas de auxilio, que são aprofundadas a seguir.

\subsection{Coleta de dados e informações}

O primeiro passo para analisar um sistema de informação começa pela coleta dos dados e informações. Para este trabalho, estes dados foram divididos em dois grupos: gerais e específicos. Os gerais são os fatores que determinaram o contexto de fundo para o estudo. No capítulo anterior, discutiu-se a forma como as caraterísticas da organização produzem um arranjo único de requisitos de informação. Portanto, ao analisar um sistema de informação de uma empresa deve-se primeiramente identificar estas características, quais sejam: configuração da estrutura organizacional, grau de centralização das informações, complexidade e grau de formalização.

Adicionalmente às caraterísticas inerentes à estrutura organizacional de cada empresa construtora visitada, não se deve esquecer que existem também outros fatores que vão influenciar os fluxos de informações, quais sejam: a estratégia, a filosofia de gestão, o porte, a tecnologia e o ambiente (BURTON; OBEL, 1995). 
Já os dados e informações específicos referem-se àqueles que serviram para entender exclusivamente o fluxo de informações relativas à gestão de materiais em uma empresa. Nesse caso, os dados levantados foram: os participantes envolvidos, as etapas pelas quais passavam a informação, a documentação que subsidiava estes fluxos e as tecnologias da informação que davam suporte a estes fluxos.

Sendo a presente pesquisa de caracter exploratório, as ferramentas utilizadas para a coleta destes dados e informações foram os questionários semi-estruturados e as entrevistas gravadas, como foi detalhado na metodologia exposta no Capítulo 1. Estes questionários podem ser encontrados no Anexo.

\subsection{Caracterização dos modelos das empresas}

Esta segunda etapa consiste em transformar as informações e dados coletados em um modelo. Segundo ASKIN; STANDRIDGE (1993), os modelos servem para: otimizar; predizer desempenho; controlar; entender o sistema; e para justificar decisões ou pontos de vista.

Estes mesmos autores acrescentam que o processo de desenvolvimento de um modelo tem um alto valor, sendo que o aprendizado durante a sua estruturação aumenta o entendimento do sistema real.

As principais ferramentas utilizadas neste trabalho para a elaboração de modelos foram as seguintes:

A. Organograma: é a representação da configuração da estrutura funcional e, portanto, também da estrutura de informação em uma empresa. $\mathrm{O}$ organograma serve para visualizar as diversas áreas nas quais está dividida a empresa e as hierarquias existentes. Além disso, ajuda a identificar as pessoas chaves para entrevistas futuras. 
Também dá uma idéia de como acontecem os fluxos de informações dentro da empresa (ver Figura 9, Figura 12 e Figura 14).

B. Matriz de responsabilidades: é uma matriz que serve para estabelecer as responsabilidades de cada área da empresa. As entradas da matriz são por um lado os envolvidos, que podem ser uma pessoa específica ou um departamento da empresa e, por outro, os processos que se desenvolvem no interior da empresa, além de outras informações e documentos da obra que sirvam para subsidiar a gestão de materiais.

Nesta matriz se indica quem executa, aprova e recebe ou controla determinado processo e portanto ajuda a visualizar se as pessoas que tomam as decisões (aprovam) são as adequadas. Para tal, parte-se da regra de que a decisão deve ser tomada onde exista a maior quantidade de informação (GALBRAITH, 1974).

Neste trabalho somente foram colocadas os processos que tivessem relação com a gestão de materiais da empresa construtora (ver Tabela 6, Tabela 8 e Tabela 10).

C. Diagrama de Fluxo de Dados (DFD): diversos autores, como DE MARCO (1979) e GANE; SARSON (1979) reconhecem que para a análise de um sistema de informação em uma empresa é importante começar-se por um diagrama de fluxo de dados - DFD. Ele servirá de modelo para reproduzir, entender e otimizar o sistema.

Este diagrama serve para representar as entidades que intervêm no fluxo de informações, os dados ou as informações e os bancos de dados. Serve igualmente para simbolizar o fluxo de dados na organização de forma lógica (o que acontece) sem se preocupar em dizer como isto acontece. A idéia é representar, através do diagrama, os processos que são utilizados e de onde vêm e para onde vão os dados. 
BARTON et al. (1985) ressalta a importância de se verificar os diagramas com os usuários, para garantir a confiabilidade dos mesmos.

A representação gráfica do diagrama se dá através de quatro símbolos, conforme a figura 6 .

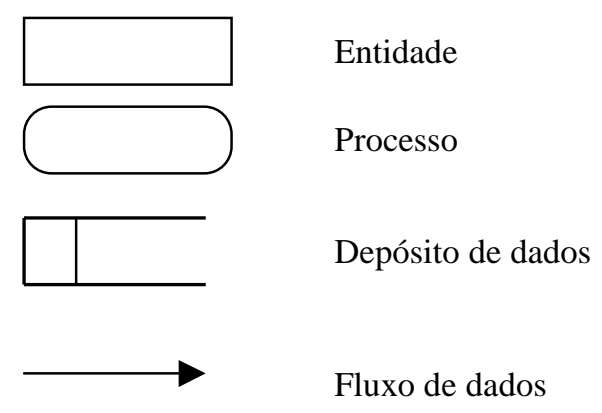

Figura 6.- Símbolos do DFD

- Retângulo: representa uma entidade externa (empresa, pessoa, departamento), quer dizer, categorias lógicas ou pessoas que atuam como uma fonte ou um destino para as transações. Para evitar o cruzamento de linhas de fluxo de dados, a mesma entidade pode ser desenhada mais de uma vez no mesmo diagrama; as duas (ou mais) caixas, por entidade, podem ser identificadas por uma linha inclinada no canto inferior direita.

- Retângulo com os vértices arredondados: representa um processo de transformação de dados. Este pode ser opcionalmente dividido em três áreas, como ilustra a figura 7.

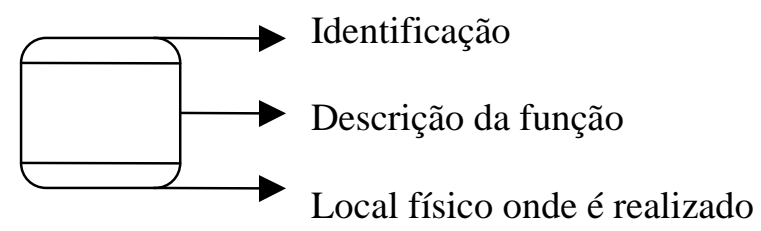

Figura 7.- Símbolo do processo

- Retângulo aberto: representa um depósito de dados. 
- Flecha: representa a troca de dados de um ponto a outro.

Caso necessário, sempre é possível expandir um processo em um novo DFD e assim evitar que o diagrama fique confuso.

O DFD converte-se então em um modelo para a análise da consistência dos fluxos de dados ou informações existentes, servindo assim à identificação das possíveis formas para racionalizá-los.

D. Dicionário de Dados: uma outra ferramenta que complementa o DFD é o dicionário de dados (DD). Este dicionário serve para definir os símbolos utilizados no diagrama de fluxo de dados. Também fornece informação sobre a definição, estrutura e utilização dos dados empregados pela organização. GANE; SARSON (1979) afirmam que, no desenvolvimento de sistemas com interfaces com outros sistemas, os DD podem ajudar os analistas a evitarem redundâncias de dados que são necessários a várias entidades de uma mesma organização. Quando estes dados são pensados no início do desenvolvimento de um sistema, tem-se melhores condições para se criar uma base de dados comum para toda a empresa.

\subsection{Análise dos modelos}

A análise dos modelos representativos das empresas estudadas deve ser dividida em duas etapas:

i) na primeira etapa, a idéia é a de se identificar os agentes e localizar as interfaces onde acontecem os principais problemas relacionados com os fluxos de informações, quais sejam: informações imprecisas e incompletas, informações duplicadas, perdas da informação, morosidade na informação, falta de acessibilidade das informações e dados e falta de retroalimentação do processo. 
ii) A segunda etapa constitui a essência da análise e consiste na identificação das causas dos problemas anteriores. Para tal, considera-se o fluxo de informações como um processo que inclui etapas de transformação, movimentação, espera e armazenagem. Sendo que as únicas etapas que agregam valor ao processo são as de transformação, neste caso, processamento de informações, a idéia é a de otimizá-las e tratar de reduzir ou eliminar as demais. Esta análise divide-se em duas partes:

(1) análise da estrutura do fluxo de informações: a idéia desta parte é a de se estudar as linhas de comunicação por onde a informação e os dados fluem. O objetivo é o de se otimizar as etapas que não agregam valor, quais sejam: movimentação, espera e armazenagem, através do entendimento da estrutura dos fluxos de informação. Nesta etapa somente interessa a forma, o desenho dos fluxos de informações, não sendo necessário se preocupar com a informação que circula por eles. Para tanto, devem se abordar os seguintes aspectos para cada empresa construtora:

(a) determinação das pessoas envolvidas e das etapas pelas quais circula a informação. Para tal utilizou-se os DFD e os DD.

(b) Estudo dos aspectos organizacionais: sendo que a estrutura organizacional determina o caminho da informação formal na empresa, deve-se determinar se existe uma harmonia entre as características da estrutura organizacional relativa à área de gestão de materiais e os fatores condicionantes da organização (ver Tabela 4). 
Tabela 4.- Estrutura Organizacional versus Condicionantes

\begin{tabular}{|c|c|c|}
\hline $\begin{array}{c}\text { Características da } \\
\text { Estrutura organizacional }\end{array}$ & versus & Fatores Condicionantes \\
\hline Configuração & \multirow{5}{*}{ versus } & Porte \\
\hline Grau de centralização & & Estratégia \\
\hline Grau de formalização & & Modelo de gestão \\
\hline Grau de complexidade & & Tecnologia \\
\hline (horizontal, vertical espacial) & & Ambiente \\
\hline
\end{tabular}

Deve-se levar em conta, por exemplo, se o grau de centralização é adequado ao porte e complexidade da empresa, se a configuração existente é a melhor para a estratégia, o modelo de gestão e as tecnologias utilizadas, etc. As ferramentas úteis para esta etapa são os organogramas e a análise dos documentos fornecidos pelas empresas.

(c) Análise das funções dos departamentos envolvidos: orçamentos, suprimentos, contas a pagar e obras. A idéia é a de se conseguir determinar se os departamentos envolvidos são absolutamente necessários no processo e se suas funções estão claramente definidas. Neste caso são empregadas as matrizes de decisões e os organogramas das empresas.

(d) Estudo do processo de tomada de decisões para a área de suprimentos da empresa construtora. Deve-se determinar os envolvidos e a quantidade de níveis de aprovação na formulação de requisições, compras e pedidos de compra. Como no caso anterior serão úteis as matrizes de decisão.

(e) Estudo das tecnologias da informação que dão suporte aos fluxos de informação na área da logística (software, hardware, bases de dados, rede, etc.). Neste caso deve-se responder às seguintes perguntas:

(1) Quais são os principais softwares utilizados pelos departamentos envolvidos? Existe um sistema informatizado integrando funcionalmente 
a empresa? Como opera? Que áreas e departamentos estão sendo beneficiados?

(2) Qual é a postura da empresa quanto ao tema da TI? A TI é vista como uma estratégia ou uma ferramenta?

(3) A empresa está investindo no uso da TI?

(4) Qual é a infra-estrutura atual da empresa no que se refere à TI?

(5) A estrutura do sistema informatizado está refletindo a estrutura organizacional da empresa?

(2) Análise das etapas através das quais é processada a informação: este segundo enfoque já não se preocupa com as linhas de comunicação por onde fluem as informações, mas com o conteúdo da informação que constituem o resultado das etapas pelas quais as mesmas são processadas. Como foi comentado, esta é a etapa que agrega valor ao sistema e portanto requer uma análise cuidadosa.

Sendo que cada etapa representa um processo pelo qual a informação é processada, as possíveis fontes de erros podem vir: dos indivíduos que processam a informação, dos dados de entrada para efetuar as operações necessárias para o processamento ou das informações adicionais requeridas (ver Figura 8). Portanto, deve-se fazer com que todos estes elementos tenham a confiabilidade necessária para garantir qualidade na informação de saída.

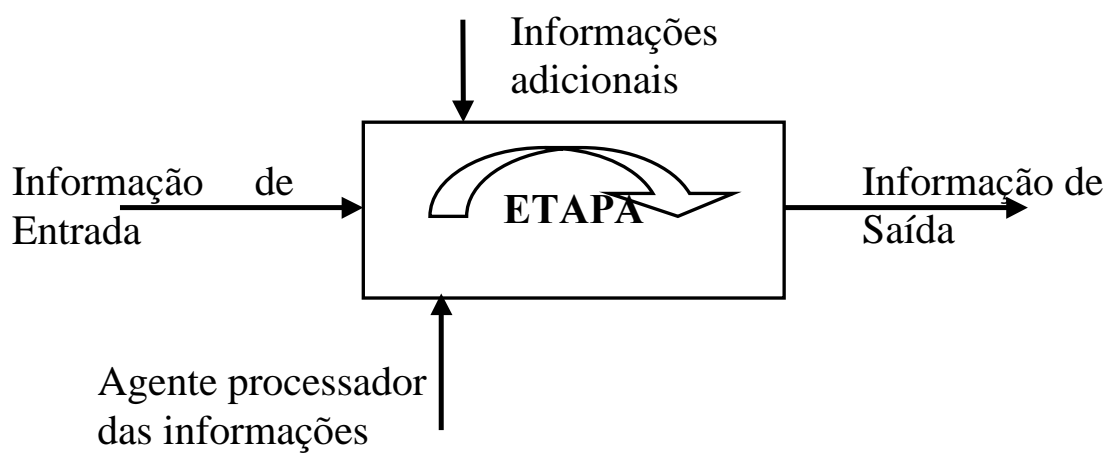

Figura 8.- Elementos do processamento de informações 
Neste caso, deve se trabalhar com cada uma das etapas pelas quais as informações relativas à gestão de materiais vai percorrer, quais sejam: identificação da necessidade do material, elaboração da requisição, aprovação da requisição, formulação da solicitação da cotação, elaboração da cotação, escolha do fornecedor, compra e formulação do pedido de compra, recepção do produto, e pagamento.

Deve-se levar em conta as seguintes questões:

(a) Estão os requisitos de informação para cada etapa claramente definidos? Quais são estes requisitos? É interessante observar se nas respostas a estas perguntas serão citados os tópicos identificados no Capítulo 2, quais sejam: a qualidade do planejamento da produção (requisito indispensável para identificar a necessidade de material com antecipação); a existência de especificações e procedimentos de compra, execução e controle; a avaliação dos fornecedores; etc.

(b) Qual é o grau de formalização dos procedimentos da área de suprimentos em cada uma das empresas?

(c) Quais são os documentos que suportam os fluxos de informação? Qual é o grau de clareza destes documentos?

(d) A informação é facilmente acessível a todos os usuários?

(e) Os funcionários que processam estas informações apresentam o perfil adequado ao seu cargo?

(f) Estão as responsabilidades de cada cargo definidas pela empresa?

Feitas estas considerações, passa-se aos estudos de caso. 


\section{Capítulo 6 Estudo de Caso}

Neste capítulo apresenta-se inicialmente as informações coletadas nas três empresas construtoras estudadas, começando pela caracterização da empresa, continuando com a descrição da sua estrutura organizacional e da sua forma de gestão de materiais e finalizando com a caracterização dos fluxos de informações relativas à gestão de materiais nelas existente. Além disso, apresenta-se o organograma, a matriz de decisões e o DFD de cada uma das empresas, aqui identificadas pelas letras A, B e C.

\subsection{Empresas Construtoras}

\subsubsection{Empresa A.}

\subsubsection{Caracterização da Empresa}

Esta empresa caracteriza-se por ser uma incorporadora - construtora com vinte anos no mercado. Encontra-se sediada em São Paulo e tem como principal área de atuação o mercado privado, tanto residencial quanto comercial. Em ambos os casos, o padrão das obras varia entre médio e médio alto.

A empresa é de médio porte, sendo que conta com 48 empregados no escritório principal enquanto que nas obras existem aproximadamente 250 empregados. Este último número inclui engenheiros, estagiários, mestres, carpinteiros e pessoal de apoio para a limpeza em obra. Além deste pessoal, a empresa trabalha com 200 funcionários de subempreiteiros, dentre os quais encontram-se operários elétricos, hidráulicos e pintores.

Na época da coleta de dados (junho 99), a empresa tinha 32 prédios e dois condomínios com 18 casas já entregues e sete obras andamento, das quais uma era comercial e as seis restantes residenciais, sendo que destas últimas duas eram flats. Estas obras perfaziam um total aproximado de $400.000 \mathrm{~m}^{2}$ construídos. 
Uma característica importante desta empresa é que nos últimos oito anos ela vinha implementando um programa de racionalização e de implantação de novas tecnologias construtivas. $\mathrm{O}$ interesse da empresa neste programa surgiu a partir de um contato mais próximo com os professores e pesquisadores da Escola Politécnica, no qual desde o primeiro momento esteve envolvida a diretoria técnica da empresa. Através deste programa, a empresa começou a mudar as tecnologias tradicionais por tecnologias racionalizadas com o intuito de reduzir perdas e otimizar os recursos. Com este fim, criou um departamento de tecnologia o qual, além de desenvolver e implantar tecnologias, se encarrega do treinamento do pessoal.

A empresa tem um comprometimento total com os clientes e uma de suas principais metas é a da diminuição de problemas pós - entrega em suas obras.

\subsubsection{Estrutura Organizacional da Empresa}

Para entender o sistema logístico da empresa, começa-se por descrever a sua estrutura organizacional, já que o processo de tomada decisões está fortemente ligado a essa estrutura.

A empresa apresenta uma estrutura hierárquica funcional tradicional (Figura 9). Ela possui quatro áreas principais, quais sejam: técnica; marketing; administrativa; compra de terrenos. Sendo o foco deste trabalho a logística, aprofundou-se nas áreas técnica e administrativa (contas a pagar), que são as que estão diretamente relacionadas a ela.

Do organograma da empresa (ver Figura 9), pode-se perceber que da área técnica dependem as áreas de suprimentos, compras técnicas, orçamentos e controle de custos, assistência técnica, coordenação de obras e coordenação de projetos As principais funções e caraterísticas destas áreas são: 


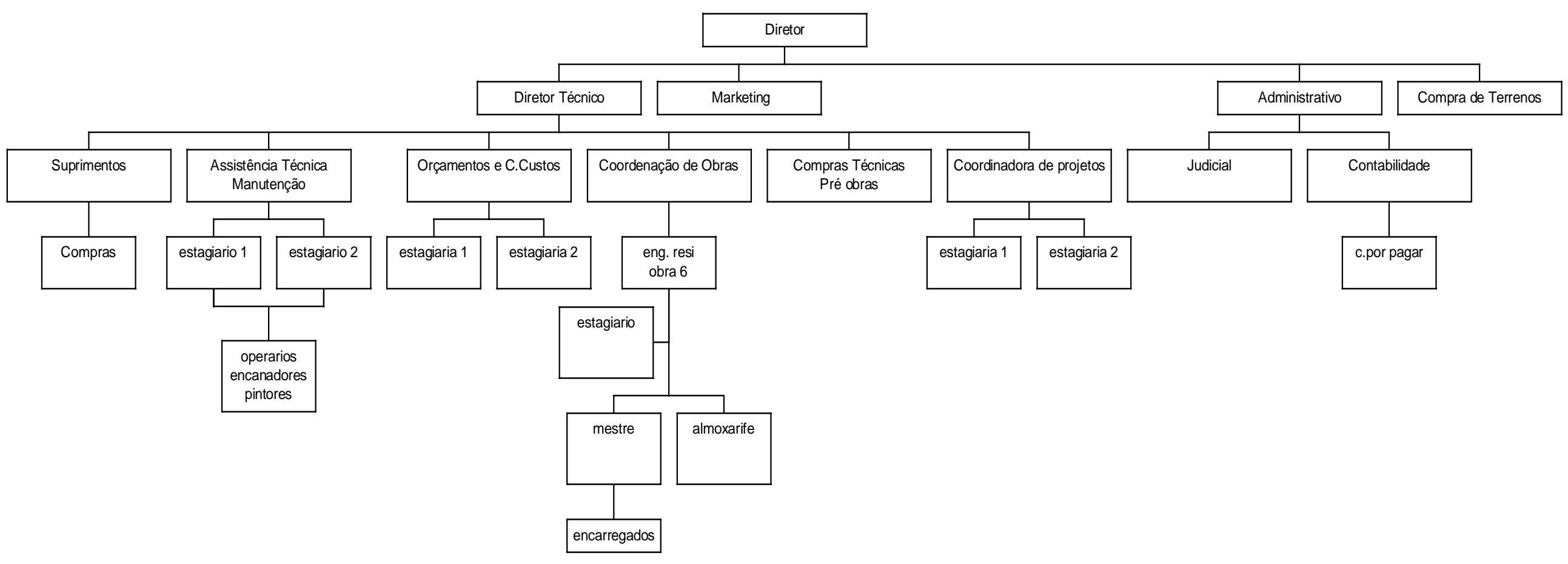

Figura 9.- Organograma Empresa A 
- área de suprimentos: caracteriza-se por ser centralizada; as obras fazem seus pedidos e os transmitem por meios eletrônicos ao escritório principal (on-line). A função desta área é basicamente a de uma central de compras de comodities ou materiais que não precisem de um conhecimento técnico específico para realizar as compras. As aprovações dos pedidos dependem exclusivamente do diretor técnico, sendo que as cotações podem ser aprovadas por ele ou pelo gerente de suprimentos, dependendo da montante da compra. No caso de alguns produtos, como argamassas e areia, a central de suprimentos define o preço unitário com o fornecedor e as obras pedem diretamente ao fornecedor a quantidade que precisarem.

- Compras técnicas e pré - obras: esta área encarrega-se das compras de materiais ou equipamentos que precisam de um conhecimento ou critério específico para decidir sobre a compra, como são as esquadrias, elevadores, etc. Ela também é responsável pela pesquisa de novos produtos. Geralmente, tanto as aprovações de pedidos quanto de cotações são feitas pelo diretor técnico e pelo encarregado desta área. Além destas funções, esta área também toma conta das obras quando estas estão em uma etapa inicial.

- Orçamentos e controle de custos: esta área encarrega-se da elaboração de orçamentos desde a concepção do empreendimento (quando as plantas ainda não existem) até a elaboração do orçamento final (quando todos os projetos já estão prontos). O orçamento inicial ou pré-orçamento é feito com base nas plantas de prefeitura, assumindo-se acabamentos que dependem do padrão do empreendimento a se construir. Após, a medida que os projetistas terminam seus projetos, vai se completando a informação e elaborando o orçamento final. Geralmente este orçamento fica pronto já iniciada a obra. Terminado o orçamento, esta área entrega ao engenheiro responsável pela obra um relatório que inclui todos os orçamentos, 
quantidades dos recursos, preços de recursos e composição de preços unitários assumidos. Além disso, esta área também se responsabiliza pela preparação de um cronograma físico - financeiro inicial para a programação do fluxo de caixa para a obra.

Uma outra função desta área é a de controlar mensalmente os custos da obra e compará-los com o orçado. Para tanto, todos os meses avalia-se o avanço físico da obra e coletam-se as notas fiscais.

- Assistência Técnica: encarrega-se basicamente do atendimento ao cliente quanto a problemas nas obras já entregues.

- Coordenação de obras: encarregada da supervisão das obras. Por enquanto (junho 99), existe somente um coordenador que se encarrega de dar apoio técnico às obras em andamento. Além disso, o coordenador reúne-se semanalmente com o engenheiro de obra para planejar a produção semanal e verificar se o previsto na reunião anterior foi cumprido. Este cargo é praticamente novo (junho 99) e foi criado com a finalidade de descentralizar a tomada de decisões que anteriormente eram tomadas pelo diretor técnico. A idéia é a de que, com o tempo, o diretor encarregar-se-á de decisões de caráter estratégico e o coordenador das de caráter tático e operacional.

- Obra: a cargo do engenheiro residente, que tem a função de supervisionar e controlar a realização da obra segundo os projetos, de acordo com o orçamento e com uma qualidade que garanta o não aparecimento de problemas pós-entrega ocasionados por um controle inadequado durante a execução. É importante mencionar que, não existindo uma área de planejamento na empresa, o engenheiro residente torna-se o responsável pelo planejamento de sua obra. Ele também é o responsável por encaminhar os pedidos de materiais à central de 
suprimentos e está autorizado a efetuar compras no caso de existir alguma urgência na obra.

Além do engenheiro, em cada obra existem um almoxarife e dois estagiários. $\mathrm{O}$ almoxarife é o responsável pelo recebimento dos materiais, controle de estoques e arquivamento das notas fiscais. No caso dos estagiários, um deles está encarregado de apoiar o controle da qualidade da obra e o outro de dar apoio em diversas atividades.

- Coordenação de projetos: a função desta área é a de garantir que os diversos projetos sejam compatíveis. Responsabiliza-se também pela coordenação entre projetistas.

\subsubsection{Gestão de Materiais}

Como já foi indicado, a responsabilidade pelo planejamento da produção e pela requisição dos materiais na obra está a cargo do engenheiro residente.

Nesta empresa, somente o planejamento total da obra é obrigatório. Cada engenheiro, ao receber a responsabilidade por uma obra, deve fazer no início da mesma um cronograma físico-financeiro, que deverá servir para toda sua duração, sendo permanentemente avaliado.

Normalmente, o que acontece é que nas reuniões semanais de coordenação se programe o que vai se fazer na semana seguinte. Além disso, diariamente realizam-se reuniões com os mestres e encarregados, para se verificar o avanço e se programar as atividades do dia seguinte. Já tendo as informações da produção e o relatório dos estoques, é possível para o engenheiro da obra fazer uma programação das compras; porém, este procedimento não é obrigatório e depende de cada engenheiro residente. 
Quanto ao sistema informatizado que dá suporte ao processo de suprimentos, tem-se que, embora as áreas de orçamentos e controle de custos, suprimentos e planejamento da obra precisem de informações comuns, este sistema não facilita esta troca de informações. O software de suprimentos (compras) não é compatível com o de orçamentos e controle de custos.

No entanto, um ponto positivo é o de que todas obras possuem um computador que pode ter aceso direto à rede da empresa, e mais especificamente ao programa de suprimentos, através da Intranet. Isso facilita o rápido encaminhamento da requisição de materiais ao escritório da empresa.

Por outro lado, devido à estrutura organizacional verticalizada, como regra geral, as aprovações de pedidos e cotações têm que passar necessariamente pelo diretor técnico da empresa. No entanto, existem casos de alguns materiais que podem ser pedidos diretamente ao fornecedor sem precisar da aprovação do escritório central. Este é o caso das argamassas ensacadas, blocos, areia e agregados e concreto estrutural. Como já dito, para estes itens, a área de suprimentos define um preço com o fornecedor e a obra pode pedi-los diretamente, dando assim flexibilidade ao processo.

A área de suprimentos não recebe um cronograma de compras no inicio de cada obra. Os pedidos são feitos de acordo com a necessidade da obra (geralmente as requisições de obra são diárias), o que muitas vezes não permite combinar pedidos de diferentes obras para se fazer uma compra conjunta. Tal postura acaba assim inviabilizando uma das principais vantagens de se ter uma área de suprimentos centralizada.

Quanto à avaliação de fornecedores, a empresa ainda não tem uma sistemática própria. No caso de se tratar de um novo fornecedor, eles ligam para seus clientes para pedir 
uma referência. No caso da madeira, por exemplo, as vezes se pegam amostras e se o fornecedor enviar material diferente este não será recebido na obra.

Já se tem registrados alguns procedimentos de execução e controle de qualidade (estrutura, alvenaria, contrapiso) e outros de recebimento de materiais, mas estes ainda são poucos.

\subsection{Fluxo de informações}

Neste item, descreve-se o caminho que a requisição deverá percorrer até que a compra do material seja realizada e o mesmo seja entregue na obra. Para facilitar esta descrição, este processo será dividido em etapas e modelado através dos DFD (ver Figura 10 e Figura 11):

- requisição do material: geralmente, a sistemática do uso da requisição dos materiais começa na etapa de estruturas ou no final das fundações, pois, no início da obra, as compras são muito escassas. Já a partir das etapas seguintes, a demanda por material é grande e constante. A identificação das necessidades de materiais é feita, em um primeiro momento, com auxilio da quantificação dos recursos registrada no "manual do orçamento". As requisições seguintes são identificadas principalmente pelo levantamento feito pelo almoxarife, em função dos controles de estoques. Este levantamento é feito semanalmente e é registrado manualmente em um formulário (não é registrado no computador). Após, é entregue ao engenheiro da obra, que é quem complementa esta informação com os dados da produção e identifica os recursos a requisitar. É importante comentar que, como o planejamento semanal não está formalizado, os critérios para a requisição de materiais vão depender de cada engenheiro, sendo ele o responsável direto pela formulação desta requisição. 
A requisição do material pode ser enviada diretamente para o fornecedor ou para a central de suprimentos; isso vai depender do tipo de material (ver Tabela 5).

No caso em que a requisição é feita para a central de suprimentos, o engenheiro entra na rede através da Intranet com uma senha, tendo aceso ao programa de suprimentos. Para fazer a requisição deve indicar claramente o código do material requisitado, a quantidade, as especificações, o prazo de entrega, o local a ser utilizado e o serviço no qual vai ser utilizado, segundo o formato do computador. Para uniformizar os pedidos existem códigos para cada material; no caso em que o material requisitado não exista na base de dados, pode ser enviado com o nome de outro semelhante, indicando detalhadamente as especificações do material requerido.

Como já foi indicado, existem materiais que são diretamente solicitados ao fornecedor (ver Tabela 5). A central de suprimentos define o preço unitário e os pedidos são feitos diretamente da obra, via telefone ou fax. Nestes casos, o procedimento não é padronizado (não existem formulários especiais), os dados principais da informação sendo: quantidade, data de entrega e especificação do material.

Apesar de que as compras de materiais devem ser feitas através da central de suprimentos, se existir alguma compra urgente para a obra que não foi prevista com antecipação $^{13}$, o engenheiro residente tem o poder de fazê-la sem passar pela central de suprimentos.

\footnotetext{
${ }^{13}$ A central de suprimentos solicita que os pedidos sejam feitos com uma semana de antecipação, para evitar qualquer imprevisto.
} 
Tabela 5.- Tabela de Requisição de Materiais para Empresa A

\begin{tabular}{|c|c|c|c|c|c|}
\hline Tipo de Material & Recebe a requisição & Etapa da obra & $\begin{array}{c}\text { Periodicidade de } \\
\text { requisições durante a } \\
\text { obra }\end{array}$ & $\begin{array}{c}\text { Tempo de } \\
\text { antecipação } \\
\text { para fazer a } \\
\text { requisição }\end{array}$ & Observações \\
\hline \multirow{2}{*}{ Fôrmas } & Fornecedor/ escoramento & \multirow{2}{*}{ Estruturas } & \multirow{2}{*}{$\begin{array}{c}\text { Variável: trata-se de pedir } \\
\text { os materiais segundo a } \\
\text { necessidade, para ter } \\
\text { estoques mínimos }\end{array}$} & $\begin{array}{l}\text { Escoramento. } 15 \\
\text { dias }\end{array}$ & Escoramento metálico (alugado) \\
\hline & $\begin{array}{l}\text { Central de suprimentos/ } \\
\text { madeira }\end{array}$ & & & Madeira: 7 dias & Molde (fabricado em obra) \\
\hline \multirow{2}{*}{ Aço e Armadura } & $\begin{array}{l}\text { Central de suprimentos } \\
\text { (barras de aço) }\end{array}$ & \multirow[t]{2}{*}{ Estruturas } & $\begin{array}{c}\begin{array}{c}\text { Variável, segundo o estoque } \\
\text { do fornecedor }\end{array} \\
\end{array}$ & 7 dias & Aço: comprado pela empresa \\
\hline & Fornecedor (corte e dobra) & & A cada 2 semanas & 15 dias & Armadura (corte e dobra): subempreitado \\
\hline Areia e Agregados & Fornecedor & Alven. / revest. & \multirow{5}{*}{$\begin{array}{l}\text { Variável: trata-se de pedir } \\
\text { os materiais segundo a } \\
\text { necessidade, para ter } \\
\text { estoques mínimos }\end{array}$} & 2 dias & \multirow{2}{*}{$\begin{array}{l}\text { A central de suprimentos define o preço } \\
\text { unitário com o fornecedor; a obra pede } \\
\text { direto para o fornecedor }\end{array}$} \\
\hline Argamassa & Fornecedor & Alven. / revest. & & 2 dias & \\
\hline Cimento e cal & Central de Suprimentos & Alven. / revest & & 7 dias & \\
\hline $\begin{array}{l}\text { Concreto } \\
\text { estrutural }\end{array}$ & Central de Suprimentos & Estrutura & & 2 dias & $\begin{array}{l}\text { A central de suprimentos define o preço } \\
\text { unitário com o fornecedor; a obra pede } \\
\text { direto para o fornecedor }\end{array}$ \\
\hline $\begin{array}{l}\text { Elementos de } \\
\text { alvenaria }\end{array}$ & Central de Suprimentos & Alvenaria & & 3 dias & $\begin{array}{c}\text { A obra passa para o fornecedor uma } \\
\text { programação mensal, e as entregas são } \\
\text { diárias }\end{array}$ \\
\hline Inst. elétr.- hidrá & & & & & $\begin{array}{c}\text { Fornecimento de materiais sob } \\
\text { responsabilidade da subempreiteira }\end{array}$ \\
\hline Esquadrias & & & & & $\begin{array}{c}\text { A compra é feita pela central de compras } \\
\text { técnicas }\end{array}$ \\
\hline Rev. Cerâmicos & Central de Suprimentos & Revestimentos & Pedido único & & \\
\hline Louças e Metais & Central de Suprimentos & Acabamento & Pedido único & & \\
\hline
\end{tabular}


- Aprovação da requisição: no caso dos materiais que têm que ser requisitados para a central de suprimentos, a requisição somente será válida se for aprovada pelo diretor técnico. Esta aprovação é feita diretamente no computador. Já no caso de compras urgentes não existe este passo, o pedido passando direto para o fornecedor.

- Formulação do pedido para o fornecedor: já estando a requisição aprovada pelo diretor técnico, esta é enviada aos fornecedores (mínimo cinco a seis fornecedores). Geralmente, este pedido é feito por telefone, mas se existir vários itens para se cotar, o pedido é feito por fax. No caso de compras urgentes pela obra, esta também é enviada por telefone ou fax, no mínimo a três fornecedores.

- Cotação: é feita pelo fornecedor. Normalmente, os fornecedores mandam a cotação no dia seguinte ao do envio da solicitação por fax, sendo que cada fornecedor manda a cotação segundo seu próprio formato, via fax.

- Aprovação da cotação: a aprovação da cotação vai depender do seu montante. Se for menor do que dois mil reais, é a gerente de suprimentos quem a aprova; se for maior, o diretor técnico. Somente no caso em que a solicitação é feita pela obra (compra urgente), o engenheiro residente é quem decide a compra.

- Confirmação da compra: já aprovada a compra, são emitidas três vias do pedido: uma para a obra (via malote), outra para o fornecedor (via fax) e outra para o contas a pagar. Além disso, a via que serviu para transmitir a informação ao fornecedor fica arquivada na central de suprimentos.

- Recebimento do material: quando o material chega na obra, ele é verificado comparando-o com a via de compra e com a nota fiscal. Caso o material seja aceito, a nota fiscal é recebida. Esta nota tem duas vias, uma fica na obra e a outra é enviada ao escritório central (orçamentos e controle de custos). No caso de não existir conformidade no recebimento, podem existir dois casos: $i$ ) todo o material é 
devolvido e todo o processo tem que se repetir; ii) a obra combina com o fornecedor uma forma de resolver o impasse, sendo esta a opção preferencial.

Nestes casos, a nota fiscal não é liberada para pagamento enquanto não existir conformidade na entrega.

Na Tabela 6 detalha-se a matriz de responsabilidades da empresa A. Nela além dos processos descritos anteriormente apresentam-se outras informações de entrada ou documentos que são necessários para subsidiar os fluxos de informação relativos à gestão e materiais.

Tabela 6.- Matriz de Responsabilidades (Empresa A)

\begin{tabular}{|c|c|c|c|c|c|c|}
\hline \multirow[b]{2}{*}{ Processos } & \multicolumn{6}{|c|}{ Empresa A } \\
\hline & 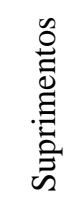 & 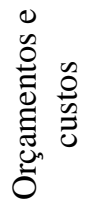 & 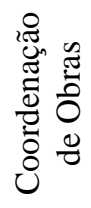 & 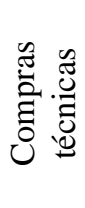 & 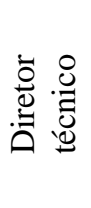 & $\frac{\pi}{0}$ \\
\hline Quantificação & & $\mathrm{E}, \mathrm{A}$ & & & & $\mathrm{R}$ \\
\hline Orçamento & & $\mathrm{E}$ & & & A & $\mathrm{R}$ \\
\hline Cronograma de produção & & $\mathrm{E}$ & & & A & $\mathrm{R}$ \\
\hline Requisição & $\mathrm{R}$ & & A & & & $\mathrm{E}$ \\
\hline Solicitação de Cotação & $\mathrm{E}, \mathrm{A}$ & & & $\mathrm{E}$ & A & \\
\hline Cotação & A & & & & A & \\
\hline Cronograma de entregas & & & & & A & $\mathrm{E}^{*}$ \\
\hline $\begin{array}{c}\text { Modificação de quantidades } \\
\text { e/ou material }\end{array}$ & A & $\mathrm{R}^{*}$ & & & & $\mathrm{E}$ \\
\hline Cronograma de materiais & & & & & & $\mathrm{E}^{*}$ \\
\hline Compras & $\mathrm{E}$ & & & $\mathrm{E}$ & & $\mathrm{R}, \mathrm{C}$ \\
\hline Especificações & & & & & $\mathrm{E}$ & $\mathrm{R}$ \\
\hline Controle de Custo & & $\mathrm{E}$ & & & $\mathrm{A}, \mathrm{R}$ & \\
\hline
\end{tabular}

E: executa; A: aprova, R: recebe; C: controla; (*): opcional.

As Figura 10 e Figura 11apresentam o DFD referentes à gestão de materiais da empresa A, para os casos de materiais do tipo I e II, respectivamente; a Tabela 7 o dicionário de dados do DFD anterior. 


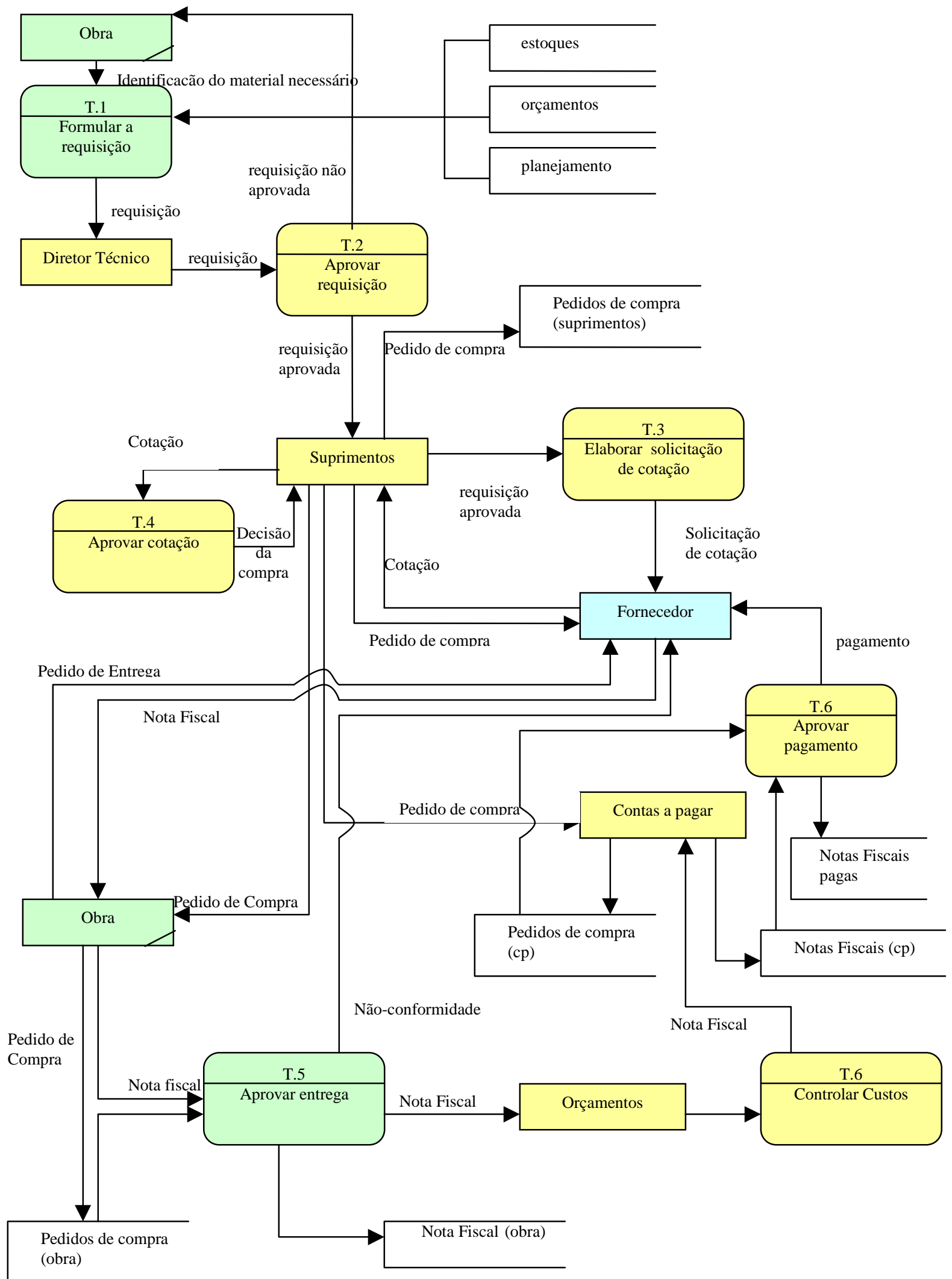

Figura 10.- DFD Empresa A. (Materiais tipo $I^{14}$ )

\footnotetext{
${ }^{14}$ Materiais que precisam ser requisitados através da central de suprimentos, ver Tabela 5.
} 


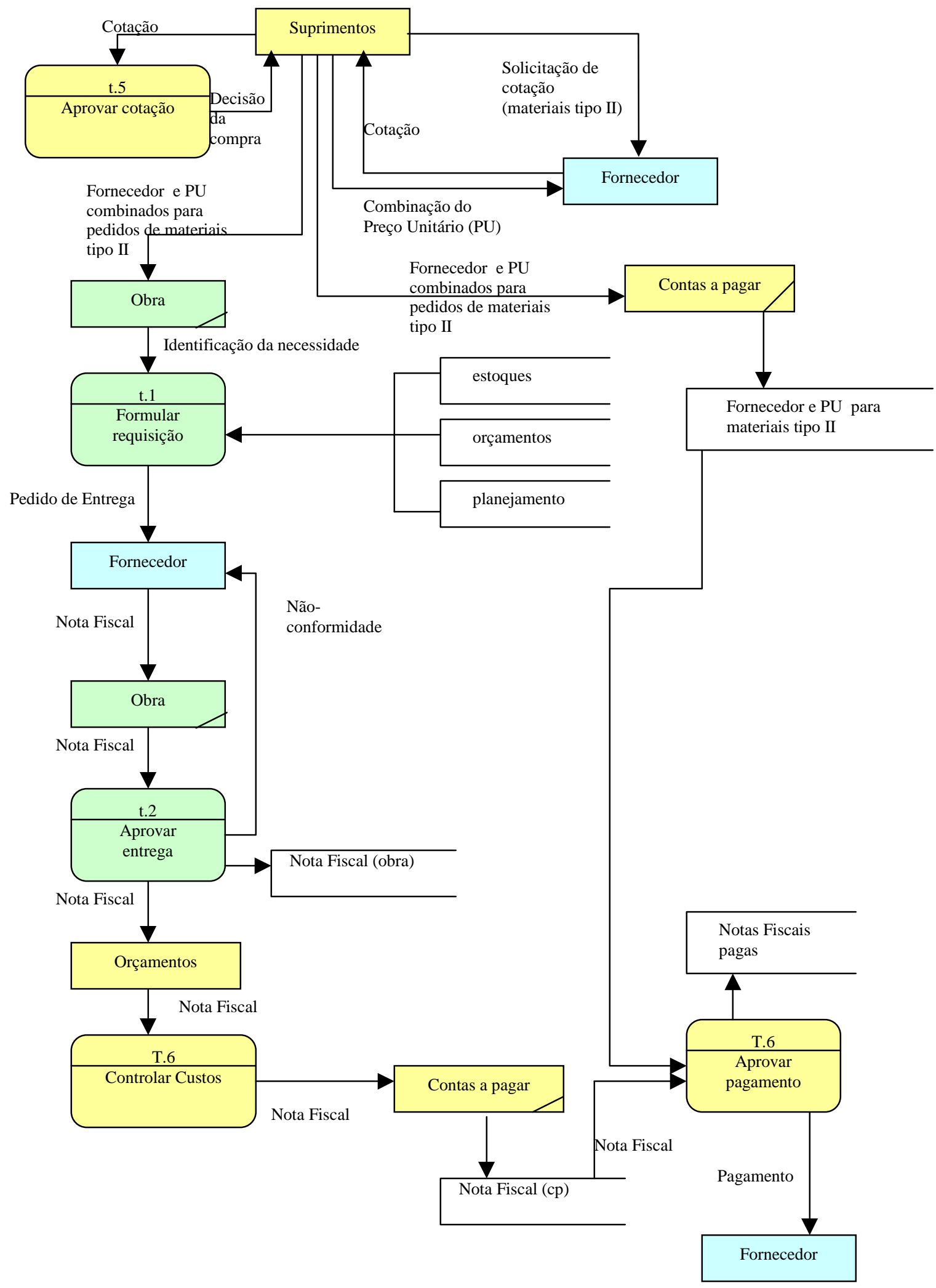

Figura 11.- DFD Empresa A. (Materiais tipo II $^{15}$ )

\footnotetext{
${ }^{15}$ Materiais os quais se faz a requisição diretamente com o fornecedor (ver Tabela 5).
} 
Tabela 7.- Dicionário de Dados (Empresa A)

\begin{tabular}{|l|l|}
\hline \multicolumn{1}{|c|}{ Informação } & \multicolumn{1}{c|}{ Dicionário de Dados } \\
\hline $\begin{array}{l}\text { Identificação do material } \\
\text { necessário }\end{array}$ & $\begin{array}{l}\text { Refere-se à identificação do material necessário na obra; } \\
\text { contém os seguintes dados: nome e quantidade. }\end{array}$ \\
\hline Requisição & $\begin{array}{l}\text { Refere-se às informações que servirão para efetuar a compra: } \\
\text { identificação do material, quantidade, local de entrega, data de } \\
\text { entrega. }\end{array}$ \\
\hline Requisição aprovada & Refere-se à requisição aprovada pelo coordenador. \\
\hline Requisição não aprovada & Refere-se à requisição não aprovada pelo coordenador. \\
\hline Solicitação da cotação & $\begin{array}{l}\text { Refere-se à informação que será enviada ao fornecedor para } \\
\text { solicitar a cotação. Contem os seguintes dados: nome do } \\
\text { material, quantidade, local de entrega, data de entrega. }\end{array}$ \\
\hline Cotação & $\begin{array}{l}\text { Refere-se ao documento enviado pelo fornecedor indicando o } \\
\text { nome do material, quantidade, preço unitário, preço total e } \\
\text { condições de pagamento e entrega. }\end{array}$ \\
\hline Decisão da compra & $\begin{array}{l}\text { Refere-se à informação que indica o(s) nome do(s) } \\
\text { fornecedor(es) do(s) qual (quais) se comprará o produto. }\end{array}$ \\
\hline Pedido de compra & $\begin{array}{l}\text { Refere-se ao documento da empresa que é feito no momento } \\
\text { da compra, onde se especifica: dados do fornecedor; nome do } \\
\text { produto; quantidade; custo unitário e total da compra; } \\
\text { condições de pagamento; identificação da obra; local de } \\
\text { entrega; data de entrega e outras informações que fazem parte } \\
\text { da compra. }\end{array}$ \\
\hline Liberação do pagamento & $\begin{array}{l}\text { Refere-se ao pedido que faz a obra ao fornecedor solicitando- } \\
\text { lhe a entrega do material em uma data específica. }\end{array}$ \\
\hline Nota Fiscal & $\begin{array}{l}\text { Refere-se à aprovação por parte da obra de material recebido. } \\
\text { É o documento que chega com o material que indica o total a } \\
\text { pagar. }\end{array}$ \\
\hline Pagamento & $\begin{array}{l}\text { Refere-se à informação que indica uma não-conformidade na } \\
\text { entrega. }\end{array}$ \\
\hline
\end{tabular}




\subsubsection{Empresa B}

\subsubsection{Caracterização da Empresa}

Sediada em São Paulo, esta empresa com já 36 anos no mercado, projeta, incorpora, constrói e comercializa empreendimentos residenciais, comerciais, escritórios e shopping centers. Neste período construiu aproximadamente 1,6 milhões de $\mathrm{m}^{2}$.

Esta empresa concentra suas operações na região de grande São Paulo mas tem projetos de expansão para outras cidades do Brasil.

Inicialmente, teve uma forte atuação no mercado residencial de alto padrão mas, posteriormente, ingressou no mercado dos flats.

É interessante mencionar que ela tem um posicionamento diferenciado com relação às outras empresas do setor quanto ao uso da tecnologia de informação (TI). Enquanto que a maioria das empresas do setor ainda não visualiza a tecnologia de informação como uma aliada para a obtenção de vantagem competitiva, esta empresa está investindo na modernização de seus sistemas informatizados com a finalidade de integrar suas diversas áreas e assim poder ter a informação no momento certo para a tomada rápida de decisões. Na época da pesquisa (junho 99), a empresa encontrava-se em um período de transição de sistema informatizado, pois estava começando a implantar um novo sistema que passaria integrar as áreas de orçamentos, controle de custos, planejamento, obra, suprimentos e contas a pagar.

\subsubsection{Estrutura Organizacional da Empresa}

A empresa é composta de quatro diretorias principais, quais sejam: técnica; comercial; financeira; e informática (ver Figura 12). Como já foi explicado no caso anterior, aprofunda-se aqui a análise da área técnica, como conseqüência do foco da pesquisa. 


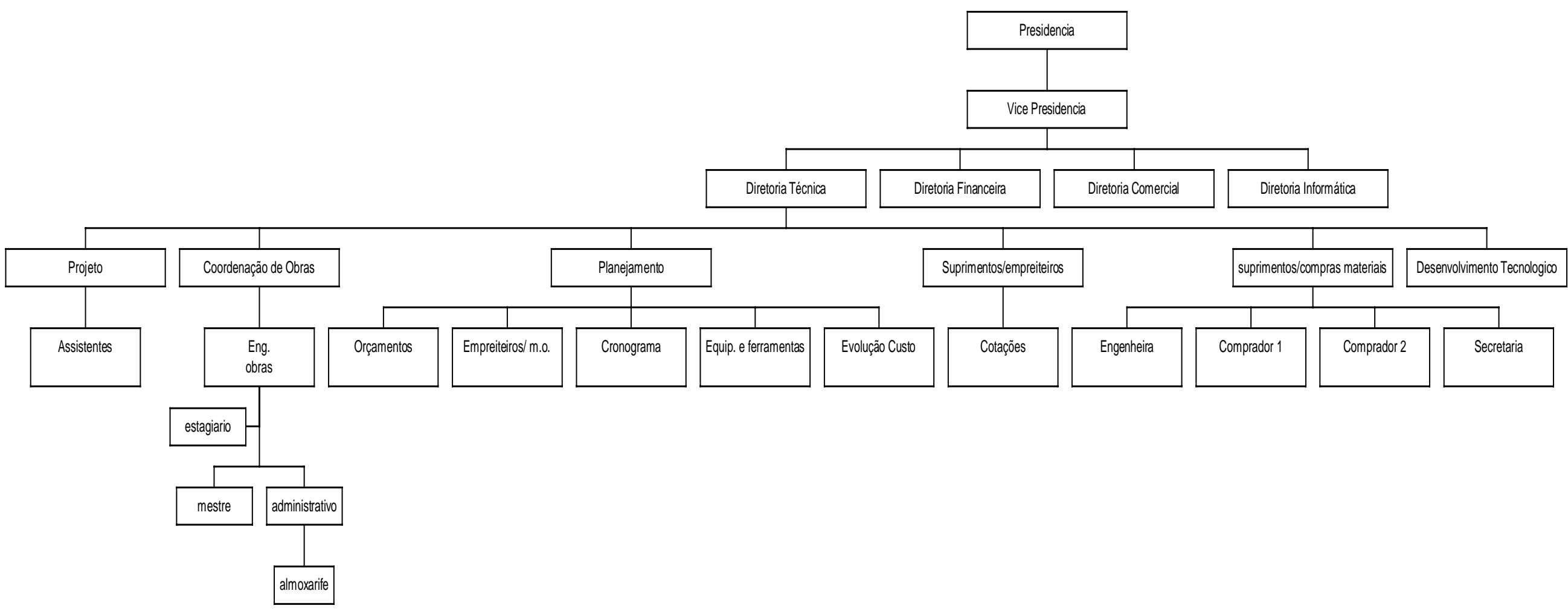

Figura 12.- Organograma Empresa B 
A área técnica divide-se em seis departamentos: planejamento, projeto, coordenação de obras, suprimentos (empreiteiros), suprimentos (compras) e desenvolvimento tecnológico que serão apresentados a seguir:

- Planejamento: com exceção da coordenação de obras, encontra-se centralizado no escritório principal. Dele dependem as seguintes áreas:

- orçamentos: tem como função principal a realização dos orçamentos das obras. Geralmente, na fase de concepção do empreendimento, é realizado um primeiro orçamento baseado em custos de obras já executadas e nas especificações dadas pela equipe de incorporação. Este primeiro orçamento serve para estudar a viabilidade do empreendimento. Conforme os projetos e demais informações vão ficando prontas, é realizado um outro orçamento, chamado orçamento executivo. Com este orçamento vai se trabalhar durante o transcurso do empreendimento. O orçamento executivo fica à disposição da empresa pela rede, mas também é entregue ao engenheiro residente de obra, sob forma de um relatório, durante os primeiros meses da obra. As informações principais contidas neste relatório são: as quantidades dos recursos, os custos de materiais e serviços e a análise de composição de preços.

Atualmente, devido ao novo software que esta sendo implantado na empresa, as obras somente poderão fazer seus pedidos se o item requisitado existir no orçamento; se não existir, esta deverá pedir sua inclusão à área de orçamentos pois, caso contrario, o sistema não aceitará a requisição do material. Esta medida foi tomada com o intuito de controlar a requisição e também como fonte de retroalimentação do sistema; cada vez que a obra requisita um material não existente no orçamento, se for aprovado, este é inserido no orçamento e na base 
de dados, o qual servirá para que a área de orçamentos possa verificar ou, se for o caso, modificar suas tabelas de composição de custos.

- Cronograma: esta área responsabiliza-se pela realização do cronograma de produção da obra. Este cronograma é feito em conjunto com o engenheiro responsável pela obra e é atualizado a cada quatro meses.

- Evolução do custo: a função desta área é a de realizar os relatórios mensais da evolução do custo da obra (EVCO). A empresa tem focado seu interesse em prever o que falta por gastar. O responsável pelo orçamento do que falta por gastar é o engenheiro de obra, mas esta área subsidia a obra com as informações para realizar este relatório. A previsão do que falta por gastar é realizada com base no orçamento executivo e avanço físico da obra.

- Equipamentos ferramentas: encarrega-se do planejamento e distribuição dos equipamentos e ferramentas para as diversas obras.

- Empreiteiros e mão-de-obra: encarrega-se da formação das equipes de trabalho para a realização dos diversos serviços e da organização e distribuição de empreiteiros de mão-de-obra.

- Projeto: área que se encarrega de estudar a viabilidade do empreendimento, da coordenação e da compatibilização dos projetos.

- Coordenação de obras: tem a função de supervisionar as diferentes obras. É composta por cinco coordenadores, que têm uma ampla experiência em obras e encarregam-se de dar apoio técnico às obras. Cada coordenador encarrega-se de tomar decisões, em um nível tático e muitas vezes operacional; as decisões estratégicas são tomadas pelo diretor técnico. 
- Obra: a cargo do engenheiro residente, o qual é o responsável direto pela realização da obra segundo o projeto e orçamento executivo. Ele também tem a função de fazer o planejamento da obra.

Além do engenheiro residente, toda obra tem um funcionário administrativo, um estagiário, um almoxarife e um mestre. O primeiro encarrega-se de fazer medições de serviço, e as requisições no computador (previamente aprovadas pelo engenheiro residente) e de dar baixa das notas fiscais de obra e conta com o apoio de um estagiário. O almoxarife é subordinado do administrativo, sendo o responsável pelo recebimento dos materiais, controle do almoxarifado, estoque de material básico e distribuição do material dentro do canteiro. Por último, o mestre está a cargo da produção da obra.

- Suprimentos - distribuição de empreiteiros: este departamento coordena e distribui a locação dos empreiteiros nas diferentes obras.

- Suprimentos - compras de materiais e contratação de empreiteiros: como no caso da empresa anterior, a função suprimentos também encontra-se centralizada. Esta área é responsável pelo encaminhamento das solicitações de compras de materiais, cotações e realização das compras de materiais para as diferentes obras. Também é a responsável pela contratação de empreiteiros (mão-de-obra). Este departamento é composto por um gerente, dois compradores, um engenheiro e uma secretária. Cada comprador é responsável por um grupo de materiais e, segundo o montante da compra, esta pode ser aprovada pelo comprador (menos de $\mathrm{R} \$ 50.000$ ), gerente (entre $\mathrm{R} \$ 50.000$ e $\mathrm{R} \$ 100.000$ ) ou diretor técnico (mais de $\mathrm{R} \$ 100.000$ ). A requisição sai da obra online mas a cotação é somente realizada quando aprovada pelo coordenador. 
- Desenvolvimento Tecnológico: é uma área recentemente formada (junho 99), cuja primeira função é a de registrar as tecnologias utilizadas pela empresa, além dos procedimentos de compras, recebimento, execução e controle. Embora já existam alguns procedimentos registrados, a responsabilidade deste departamento é a de revisar, organizar e atualizar constantemente os mesmos. A idéia é a de que cada obra, em seu início, receba um manual com estes procedimentos, os quais devem servir de referência para a realização correta dos métodos e processos construtivos. É interessante comentar que, futuramente, esta informação deverá ficar online para toda a empresa. A empresa acredita que, desta nova forma, os manuais serão mais consultados que atualmente, já que esta nova tecnologia facilitará e agilizará a busca dos procedimentos.

\subsubsection{Gestão de Materiais}

Similarmente ao acontecido com a empresa anterior, a responsabilidade pelo planejamento e pela programação dos materiais nesta empresa também fica a cargo do engenheiro residente. No entanto, ao se iniciar a obra, existe um cronograma de produção elaborado por um responsável do escritório central e pelo engenheiro da obra.

O cronograma de produção é atualizado a cada quatro meses e as informações principais nele encontradas são as datas de início e término das atividades e a sua duração total em dias. Além disso, para alguns materiais como azulejos, mármores e esquadrias, existe um cronograma de contratação onde estão indicadas as datas nas quais o engenheiro da obra deve fazer o convite, a cotação e a negociação.

Como no caso da empresa anterior, além do cronograma de produção, não existe nenhum procedimento formal que padronize a gestão de materiais. Portanto, a gestão de materiais depende principalmente da forma de trabalho do engenheiro da obra. 
Geralmente tal engenheiro faz as requisições de materiais baseado:

- no avanço da obra, o qual é obtido através de observações diretas e de informações proporcionadas pelo mestre-de-obras;

- nos dados de estoques proporcionados pelo almoxarife, indicando se falta algum material;

- $\quad$ no cronograma de produção.

Como já dito, e similarmente à empresa anterior, o departamento de suprimentos se encontra centralizado no escritório central. Este é basicamente um departamento de compras e contratações. Sendo a estrutura organizacional da empresa verticalizada, as aprovações das requisições devem passar pela aprovação do coordenador da obra. Quanto às compras, as aprovações podem ser decididas pelo diretor técnico, gerente de suprimentos e comprador, dependendo do seu montante.

Embora a empresa possua um departamento de compras centralizado, a maioria das vezes não se combinam pedidos de diferentes obras, somente em caso de compras grandes, como é o caso da dos elevadores. As obras não têm estabelecido um dia fixo para fazer requisições, estas podendo ser feitas diariamente.

Por outro lado, não existe sistemática de avaliação de fornecedores. O desempenho dos fornecedores nas obras é comunicado verbalmente ao gerente de suprimentos. Com esta informação, ele decide a participação destes fornecedores em obras futuras.

Quanto aos procedimentos de compras e recebimento, o departamento de desenvolvimento tecnológico tem a função de desenvolvê-los e de registrá-los. No entanto, já existem alguns procedimentos que vêm sendo utilizados na empresa, e a idéia é a de que, no futuro, o conjunto dos procedimentos fique acessível a toda a empresa através da rede. 
Quanto ao sistema informatizado que dá suporte à área de suprimentos, este está em uma fase de transição. A empresa está investindo no desenvolvimento de um software que integre as áreas de orçamentos, suprimentos, obras e contas a pagar.

A empresa escolheu um software já desenvolvido para uma outra empresa construtora mas este está sendo adaptado para ela. O sistema se caracteriza por possuir uma base de dados centralizada no escritório central, na qual se colocam os dados e informações por obra (orçamentos, compras já realizadas, contas pendentes, gastos totais, etc.). Cada obra tem acesso ao sistema através de uma senha. As requisições de materiais devem ser feitas através da rede. Como já comentado, o software somente permite fazer requisições de materiais que existam no orçamento. Para os materiais que não estão no orçamento, a obra tem que pedir autorização para que estes sejam adicionados ao mesmo, para então poder fazer a requisição. Como o software compara o total da quantidade pedida com aquela registrada no orçamento, ele não permite comprar mais do que o que está orçado. A modificação das quantidades somente pode ser realizada pelo escritório central, com justificativa previa da obra e autorização do diretor técnico.

Uma outra vantagem deste sistema é que a obra pode dar baixa na nota fiscal desde o canteiro, quando o recebimento do material está conforme. Esta informação fica registrada no servidor central e é utilizada pelo contas a pagar para liberar o pagamento ao fornecedor.

\subsection{Fluxos de Informações}

Neste item, descreve-se as etapas que a requisição deverá percorrer até que a compra do material seja realizada e o mesmo seja entregue na obra. Na Figura 13 representa-se este fluxo através do DFD. 
- Requisição do material: como no caso anterior o responsável por esta requisição é o engenheiro da obra. A identificação das necessidades de materiais é feita, em um primeiro momento, com auxílio da quantificação dos recursos registrada no orçamento. As requisições seguintes dependerão do avanço da obra e dos levantamentos feitos pelo almoxarife, em função dos estoques existentes na obra.

A requisição do material é feita através do computador; o engenheiro da obra entra na rede através da Internet com uma senha, tendo aceso ao programa de suprimentos. Para fazer a requisição, ele deve indicar claramente o código do material requisitado, a quantidade, as especificações, o prazo de entrega, o local a ser utilizado e o serviço no qual vai ser utilizado, segundo o formato previsto.

Como já foi comentado, não é possível fazer uma requisição se o material não existir no orçamento; nestes casos, deve-se pedir sua inclusão através do departamento de orçamentos.

- Aprovação da requisição: o responsável pela aprovação da requisição é o coordenador da obra. Assim, mesmo se a requisição é feita no computador, a área de suprimentos não formula o pedido para o fornecedor até que a requisição seja aprovada por escrito pelo coordenador. Em teoria, quando já estiver bem estabelecido o novo programa de suprimentos e planejamento, bastará somente que a aprovação seja feita online; no entanto, por enquanto é ainda necessária a assinatura do coordenador para que a requisição seja encaminhada.

- Formulação do pedido para o fornecedor: as compras na área de suprimentos são feitas divididas por grupo de materiais. Portanto, quando a requisição aprovada chega à área de suprimentos, imediatamente é distribuída ao comprador responsável pela compra do material solicitado. Ele tem que realizar um pedido de cotação para 
os fornecedores. Normalmente, este pedido é feito por telefone, mas se existir vários itens para se cotar, é feito por fax.

- Cotação: é feita pelo fornecedor. Normalmente, os fornecedores mandam a cotação no dia seguinte ao do envio da solicitação por fax, sendo que cada fornecedor manda a cotação segundo seu próprio formato, igualmente via fax.

- Aprovação da cotação: a aprovação da cotação vai depender do seu montante. Cada comprador é responsável por um grupo de materiais e, como já dito, segundo o montante da compra, esta pode ser aprovada pelo próprio comprador (menos de $\mathrm{R} \$ 50.000$ ), pelo gerente (entre $\mathrm{R} \$ 50.000$ e $\mathrm{R} \$ 100.000$ ) ou pelo diretor técnico (mais de $\mathrm{R} \$ 100.000)$.

- Confirmação da compra: já aprovada a compra, são emitidas três vias do pedido, uma para a obra (via malote), outra para o fornecedor (via fax) e outra para o contas a pagar. Além disso, a requisição se converte em um pedido de compra e é registrada na base de dados da rede.

- Recebimento do material: quando o material chega na obra, ele é verificado, comparando-o com a via de compra e com a nota fiscal. Caso o material seja aceito, a nota fiscal é recebida. Esta nota tem duas vias, uma ficando na obra e a outra sendo enviada ao escritório central (contas a pagar). Além disso, a baixa da entrega deve ser feita no computador, o engenheiro da obra colocando no pedido de compra (online) a quantidade que foi entregue em obra. Estes dados entram no sistema e vão se acumulando até que a quantidade total coincida com a quantidade orçada. Nesse momento, o sistema não permite comprar mais daquele material, a não ser que a área de orçamentos assim o autorize.

Como na empresa anterior, caso de se constatar uma não-conformidade no recebimento, podem existir dois casos: i) todo o material é devolvido e todo o 
processo tenha que se repetir; ii) a obra combina com o fornecedor uma forma de resolver o impasse, sendo esta a opção preferencial.

Nestes casos, a nota fiscal não é liberada para pagamento enquanto não que existir conformidade na entrega.

A seguir na Tabela 8 apresenta-se a matriz de responsabilidades para esta empresa.

Tabela 8.- Matriz de Responsabilidades (Empresa B)

\begin{tabular}{|c|c|c|c|c|c|c|c|c|c|}
\hline \multirow[b]{2}{*}{ Processos } & \multicolumn{9}{|c|}{ Empresa B } \\
\hline & 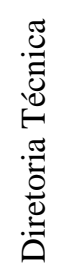 & 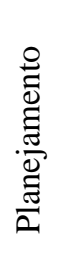 & 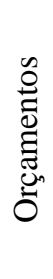 & 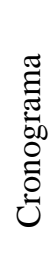 & 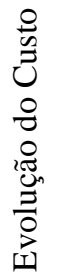 & 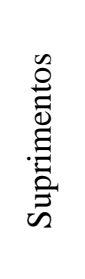 & 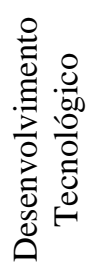 & 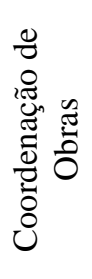 & $\tilde{0}$ \\
\hline Quantificação & & & $\mathrm{E}$ & & & & & & \\
\hline Orçamentos & & A & $\mathrm{E}$ & & & & & & $\mathrm{C}, \mathrm{R}$ \\
\hline $\begin{array}{c}\text { Cronograma de } \\
\text { produção }\end{array}$ & & A & & $\mathrm{E}$ & & & & & $\mathrm{C}, \mathrm{R}$ \\
\hline Requisição & & & & & & & & A & $\mathrm{E}$ \\
\hline $\begin{array}{c}\text { Solicitação de } \\
\text { Cotação }\end{array}$ & & & & & & $\mathrm{E}, \mathrm{A}$ & & & \\
\hline Cotação & A & & & & & $\mathrm{A}, \mathrm{R}$ & & & \\
\hline $\begin{array}{c}\text { Cronograma de } \\
\text { entregas }\end{array}$ & & & & & & & & A & $\mathrm{E}$ \\
\hline $\begin{array}{c}\text { Modificação de } \\
\text { quantidades } \\
\text { e/ou material }\end{array}$ & & A & $\mathrm{C}$ & & & & & & $\mathrm{E}$ \\
\hline $\begin{array}{c}\text { Cronograma de } \\
\text { materiais }\end{array}$ & & & & $E^{*}$ & & $\mathrm{R}$ & & & $\mathrm{C}$ \\
\hline Compras & & & & & & $\mathrm{E}, \mathrm{A}$ & & & $\mathrm{C}, \mathrm{R}$ \\
\hline Especificações & & & & & & & $\mathrm{E}, \mathrm{A}$ & & \\
\hline $\begin{array}{c}\text { Controle de } \\
\text { Custo }\end{array}$ & & A & & & $\mathrm{E}$ & & & & $\mathrm{C}$ \\
\hline
\end{tabular}

E: executa; A: aprova, R: recebe; C: controla; (*): opcional.

A Figura 13 apresenta o DFD referentes à gestão de materiais da empresa B. Já a Tabela 9 apresenta o Dicionário de Dados desse DFD, que em muito se assemelha ao da empresa A, ilustrado na a Tabela 7. 


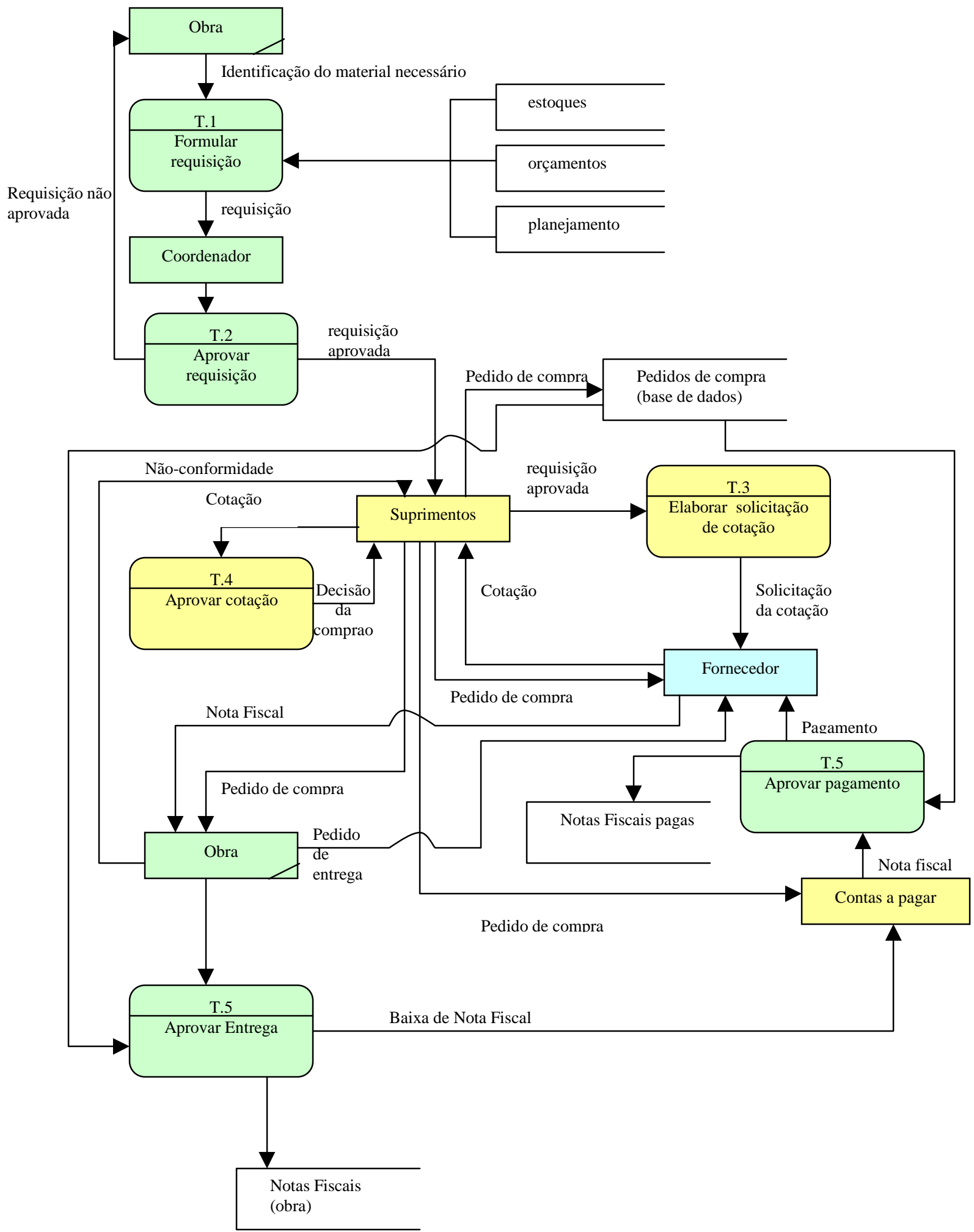

Figura 13.- DFD Empresa B 
Tabela 9.- Dicionário de Dados (Empresa B)

\begin{tabular}{|c|c|}
\hline Informação & Dicionário de Dados \\
\hline $\begin{array}{l}\text { Identificação do material } \\
\text { necessário }\end{array}$ & $\begin{array}{l}\text { Refere-se à identificação do material necessário na obra; } \\
\text { contém os seguintes dados: nome e quantidade. }\end{array}$ \\
\hline Requisição & $\begin{array}{l}\text { Refere-se às informações que servirão para efetuar a compra: } \\
\text { identificação do material, quantidade, local de entrega, data de } \\
\text { entrega. }\end{array}$ \\
\hline Requisição aprovada & Refere-se à requisição aprovada pelo coordenador. \\
\hline Requisição não aprovada & Refere-se à requisição não aprovada pelo coordenador. \\
\hline Solicitação da cotação & $\begin{array}{l}\text { Refere-se à informação que será enviada ao fornecedor para } \\
\text { solicitar a cotação. Contém os seguintes dados: nome do } \\
\text { material, quantidade, local de entrega, data de entrega. }\end{array}$ \\
\hline Cotação & $\begin{array}{l}\text { Refere-se ao documento enviado pelo fornecedor indicando o } \\
\text { nome do material, quantidade, preço unitário, preço total e } \\
\text { condições de pagamento e entrega. }\end{array}$ \\
\hline Decisão da compra & $\begin{array}{l}\text { Refere-se à informação que indica o(s) nome do(s) } \\
\text { fornecedor(es) do(s) qual (quais) se comprará o produto. }\end{array}$ \\
\hline Pedido de compra & $\begin{array}{l}\text { Refere-se ao documento da empresa que é feito no momento } \\
\text { da compra, onde se especifica: dados do fornecedor; nome do } \\
\text { produto; quantidade; custo unitário e total da compra; } \\
\text { condições de pagamento; identificação da obra; local de } \\
\text { entrega; data de entrega e outras informações que fazem parte } \\
\text { da compra. }\end{array}$ \\
\hline Pedido de entrega & $\begin{array}{l}\text { Refere-se ao pedido que faz a obra ao fornecedor solicitando- } \\
\text { lhe a entrega do material em uma data específica. }\end{array}$ \\
\hline Nota Fiscal & $\begin{array}{l}\text { É o documento que chega com o material que indica o total a } \\
\text { pagar }\end{array}$ \\
\hline Não-conformidade & $\begin{array}{l}\text { Refere-se à informação que indica uma não-conformidade na } \\
\text { entrega. }\end{array}$ \\
\hline Pagamento & Refere-se ao pagamento pela empresa feito ao fornecedor. \\
\hline
\end{tabular}




\subsubsection{Empresa C}

\subsubsection{Caracterização da Empresa}

Esta empresa caracteriza-se por ser uma incorporadora - construtora de grande porte com três anos de atuação no mercado (outubro 99) com o nome atual mas que provém de uma outra empresa imobiliária que inicio suas atividades faz 46 anos. Atua em São Paulo e no Rio de Janeiro e tem como principal área de atuação o mercado privado, tanto residencial quanto comercial. Em ambos os casos, o padrão das obras varia entre médio e médio alto. No entanto, estão começando a entrar no mercado dirigido para a baixa renda.

Na época da coleta de dados (outubro 99), a empresa tinha 637 empreendimentos já entregues que se dividiam em 7 shopping centers, 48 flats, 147 comerciais e 435 residenciais. As obras entregues perfaziam um total aproximado de $7.626 .000 \mathrm{~m}^{2}$ construídos. Por outro lado, tinha 33 empreendimentos em andamento, sendo a maior parte deles residenciais e totalizando $429.000 \mathrm{~m}^{2}$ em construção.

É importante destacar que em 1999 esta empresa foi certificada pela ISO 9002 para todos os processos de produção. Portanto, a empresa tem documentados procedimentos de contratação, recebimento, execução e controle.

\subsubsection{Estrutura Organizacional da Empresa}

A empresa apresenta uma estrutura funcional com uma tendência a estrutura por projetos, como se observa na Figura 14. Diferentemente das outras duas empresas, ela permite que cada obra se encarregue das funções que lhe correspondem. Somente, algumas funções da obra ficam sob a responsabilidade de departamentos comuns da empresa, quais sejam: suprimentos e contas a pagar, que não aparece no organograma, já que depende da Diretoria Financeira, que nele não consta). 


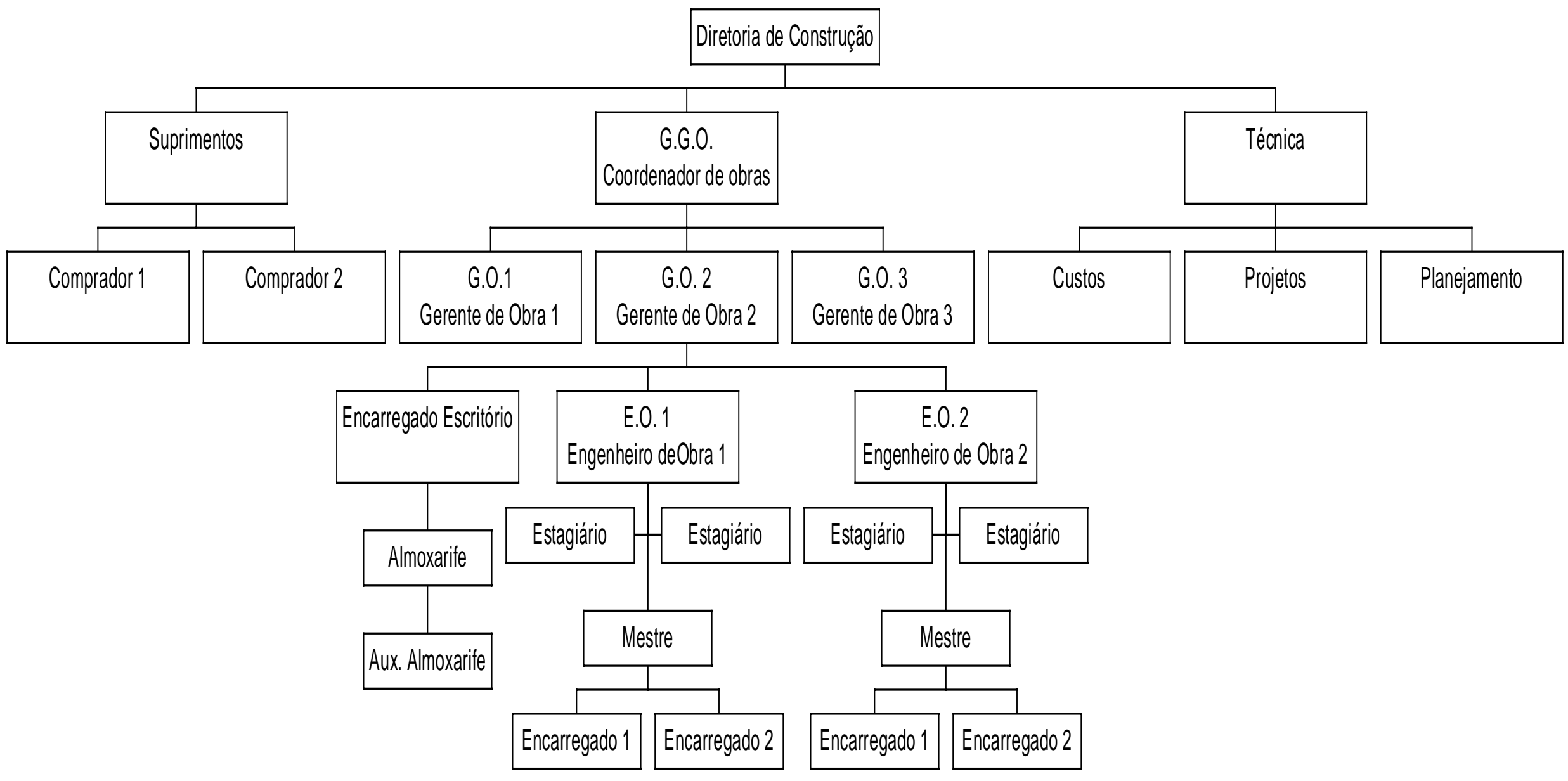

Figura 14.- Organograma Empresa C 
A seguir detalha-se as funções de alguns departamentos desta empresa. Ressalta-se que na Figura 14 somente apresenta-se a parte do organograma referente à diretoria de construção por ser a que interessa para a pesquisa.

A diretoria de construção possui três departamentos principais, quais sejam: técnico; suprimentos e coordenação de obras.

- Departamento técnico: divide-se em três áreas, quais sejam: custos, projetos e planejamento. A área de custos encarrega-se de elaborar os orçamentos iniciais (préorçamentos) dos projetos que servem para estudar a viabilidade do empreendimento; a obra se inicia com este pré-orçamento.

Este documento é feito com base em índices da empresa e nas plantas disponíveis. Já o orçamento final da obra é elaborado durante a obra, e sob a responsabilidade do seu gerente.

A área de projetos encarrega-se basicamente do estudo da viabilidade dos empreendimentos e da coordenação dos projetos. Está área é quem faz a ligação entre os projetistas, a idéia sendo tratar de conseguir projetos compatíveis com o mínimo de erros.

Por último, a área de planejamento encarrega-se da elaboração dos cronogramas iniciais das obras, que são entregues aos seus responsáveis no inicio dos trabalhos. Além de indicar as datas dos serviços, este cronograma também indica as datas nas quais deve-se começar a fazer as requisições de alguns materiais. Por outro lado, o planejamento detalhado da obra é realizado já iniciada a obra; esta função é terceirizada mas encontra-se sempre sob a responsabilidade do gerente de obras.

Uma outra função desta área é a de realizar, junto com a diretoria de construção, o chefe se suprimentos e os coordenadores de obra, o Cronograma de Suprimentos 
Semestral - CRSO. Este cronograma é feito com base nas necessidades de suprimentos semestrais das obras. Cada gerente de obra tem a responsabilidade de passar para o seu coordenador um cronograma semestral das necessidades de sua obra. O coordenador coleta os cronogramas das obras que ficam sob sua responsabilidade e junto com os outros coordenadores elabora o CRSO, que é repassado para as obras.

- Departamento de suprimentos: encarrega-se da compra de materiais para as diversas obras, tanto de São Paulo quanto do Rio de Janeiro. É formado por três funcionários, o chefe do departamento e dois compradores, cada comprador se encarregando de um grupo de materiais. Este departamento possui autonomia para realizar as compras de materiais sem consultar a diretoria de construção. No entanto, normalmente, as grandes compras são consultadas junto à diretoria, ficando esta decisão a critério do chefe de departamento.

A principais funções deste departamento são:

(a) comprar materiais: na realização da compra um dos objetivos é o de agrupar as compras de várias obras, para poder obter um melhor preço. Apesar da compra ser feita em conjunto o quadro de concorrência é por obra. Para efeitos de controle é importante que cada obra registre suas compras e contas separadamente das outras.

Existem dois tipos de documentos que auxiliam no agrupamento das compras: o CRSO, cronograma de materiais semestral de toda a empresa (anteriormente explicado), e o Boletim de Programação Mensal de Materiais - BPM, que é um documento eletrônico gerado mensalmente em cada obra para a requisição dos materiais. O BPM é elaborado pelo gerente de obras e aprovado pelo coordenador da obra. 
Realizada a compra do material deve-se gerar um documento eletrônico chamado Pedido Externo de Fornecimento - PEF. Nele deve-se indicar o nome do fornecedor, a descrição exata do material comprado, a quantidade, a obra e as datas de entrega. Este documento serve para a receber os materiais na obra e para dar baixa da nota fiscal.

(b) Manter atualizado o banco dados de fornecedores: o departamento de suprimentos é o responsável pela avaliação dos fornecedores e pela pesquisa e cadastro de novos fornecedores.

(c) Estabelecer parcerias com fornecedores: a empresa tem parcerias com alguns fornecedores como é o caso do fornecedores de louças e metais.

- Coordenação de Obras: fica sob a responsabilidade dos coordenadores de obra (GGO), cada um deles tendo sob seu controle a execução de várias obras. Eles representam um elo entre a diretoria de construção e as obras, e tomam decisões de caráter tático. Como nas outras empresas, os coordenadores são profissionais com grande experiência na execução de obras e auxiliam aos gerentes de obras (GO) na resolução de problemas no canteiro de obras os assuntos de caráter mais estratégico ligados à produção.

Além disso, eles participam da elaboração do CRSO, aprovam o BPM e decidem conjuntamente com a diretoria os assuntos de caráter mais estratégico ligados à produção.

- Obra: a cargo do Gerente de Obra (GO), o qual é o responsável direto pela realização da obra segundo o projeto. O orçamento e o planejamento ficam sob sua responsabilidade. Elaborar o orçamento inclui também fazer cotações e composição de custos. No inicio da obra, o GO solicita ao gerente de suprimentos a lista de fornecedores qualificados para fazer as cotações, podendo 
também solicitar alguns preços, como os obtidos através de parcerias com os fornecedores, já que são fixos para toda a empresa.

A quantificação dos recursos pode ser feita na obra ou terceirizada, mas sempre sob a responsabilidade do GO. De posse da quantificação feita e dos custos dos recursos ele elabora o orçamento.

O planejamento é terceirizado mas o GO deve prover todos os parâmetros necessários para que este seja realizado.

Nesta empresa, cada obra é tratada independentemente e o GO tem ampla autonomia sobre sua obra apesar de ficar subordinado ao GGO. Uma outra função do GO é a de fazer o treinamento para o almoxarife, técnicos e encarregados dos procedimentos de recebimento, execução e controle documentados pela empresa.

A avaliação do fornecedor também é feita pelo GO mensalmente, através de uma planilha informatizada onde se colocam os dados do fornecedor e o material entregue. Para cada fornecedor existem oito itens para avaliar (qualidade, prazo, atendimento, etc.); se o fornecedor tem nota abaixo de 6 ele é reavaliado; se reincidir ele é retirado do cadastro de fornecedores da empresa.

Além do Gerente de Obra, toda obra possui engenheiros de obra (a quantidade depende do porte da obra), estagiários, mestre e encarregados. Adicionalmente, existe um encarregado do escritório, um almoxarife e um auxiliar de almoxarife.

Na Tabela 10 apresentam-se alguns processos da empresa e indicam-se as responsabilidades ligadas à execução, à aprovação e ao recebimento, afeitas a eles. 
Tabela 10.- Matriz de Responsabilidades (Empresa C)

\begin{tabular}{|c|c|c|c|c|}
\hline \multirow[b]{2}{*}{ Processos } & \multicolumn{4}{|c|}{ Empresa C } \\
\hline & 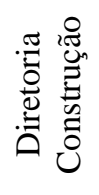 & 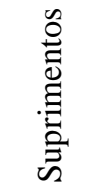 & 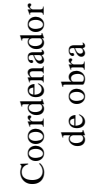 & 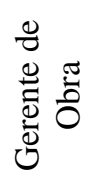 \\
\hline Quantificação & & & & $\mathrm{E}, \mathrm{A}$ \\
\hline Orçamentos & & & A & $\mathrm{E}$ \\
\hline Cronograma de produção & & & A & $\mathrm{E}$ \\
\hline Requisição & & & A & $\mathrm{E}$ \\
\hline Cronograma de suprimentos obra & & & A & $\mathrm{E}$ \\
\hline $\begin{array}{l}\text { Cronograma de suprimentos semestral } \\
\text { (CRSO) }\end{array}$ & $\mathrm{E}, \mathrm{A}$ & & $\bar{E}$ & $\mathrm{R}$ \\
\hline Boletim Mensal de Materiais (BPM) & & & A & $\mathrm{E}$ \\
\hline Solicitação de Cotação & & E & & \\
\hline Cotação & $\mathrm{A}^{*}$ & $\mathrm{~A}, \mathrm{R}$ & & \\
\hline Cronograma de entregas & & & A & $\mathrm{E}$ \\
\hline Modificação de quantidades e/ou material & & $\mathrm{R}$ & A & $\mathrm{E}$ \\
\hline Pedido externo de fornecimento (PEF) & & $\mathrm{E}, \mathrm{A}$ & & $\mathrm{R}$ \\
\hline Compras & $\mathrm{A}^{*}$ & E, A & & $\mathrm{R}, \mathrm{C}$ \\
\hline Especificações & & & & $\mathrm{R}$ \\
\hline Controle de Custo & & & A & $\mathrm{E}$ \\
\hline
\end{tabular}

E: executa; A: aprova, R: recebe; C: controla; (*): opcional.

\subsubsection{Gestão de Materiais}

O planejamento dos materiais é obrigatório e, diferentemente das outras duas empresas construtoras estudadas, não somente envolve os GO mas é uma atividade feita em conjunto com os coordenadores da obras, gerente de suprimentos e a diretoria de construção.

Em um primeiro momento, entrega-se, para cada obra, um cronograma de materiais provisório feito pela área de planejamento. Neste cronograma aparecem algumas das datas para iniciar a requisição de materiais e para emitir as cartas convites para as 
empresas fornecedoras. Já iniciada a obra, o GO faz um outro cronograma de materiais com base no orçamento executivo e no planejamento da produção da obra.

Como foi comentado, semestralmente as obras devem fazer um cronograma de materiais. Com estes documentos os coordenadores e a diretoria elaboram o CRSO, que é repassado às obras.

Com base no CRSO e nas necessidades de materiais das obras o GO emite, mensalmente, o BPM. Este documento é feito eletronicamente no programa de suprimentos da empresa e, antes de chegar para o departamento de suprimentos, deve ser aprovado pelo GGO; esta aprovação é eletrônica.

Somente se pode requisitar os materiais que existem no orçamento, mas caso se precise de um outro material o GO pode modificar o orçamento e fazer a requisição.

Os dados do BPM são: o nome do material, o código (número de grupo e serviço que coincide com o que aparece no orçamento), a quantidade e o preço que aparece no orçamento. As obras têm até o oitavo dia útil do mês para elaborar o BPM; o GGO tem até o nono dia para aprová-lo; e o gerente de suprimentos recebe os BPM até o decimo dia útil do mês.

Quanto ao departamento de suprimentos, este encontra-se centralizado no escritório da empresa e se encarrega basicamente da compra e contratação dos recursos e da realização dos contatos com os fornecedores. Como já foi comentado, apesar de o chefe deste departamento ser subordinado à Diretoria de Construção, ele tem autonomia para decidir sobre as compras; diferentemente das outras duas empresas construtoras apresentadas, não existe um montante estabelecido para a sua tomada de decisões com respeito às compras. No entanto, geralmente as compras grandes são consultadas junto à Diretoria de Construção. 
Uma outra diferença deste departamento em relação aos departamentos análogos das outras empresas estudadas é que nele as compras se fazem combinando pedidos das diferentes obras, obtendo-se, assim, melhores preços devido a compras maiores. Isso é uma consequiência do planejamento e do cronograma de materiais que, como já foi indicado, são documentos obrigatórios na empresa.

Quanto aos procedimentos de compras, recebimento e controle, sendo que a empresa acabara de ter sido certificada pela ISO 9002 quando do estudo (outubro 99), estes documentos já se encontram desenvolvidos e são repassados às obras quando estas se iniciam.

No momento das entrevistas, o sistema informatizado utilizado na área de suprimentos estava em uma fase de transição, integrando suprimentos, custos e contas a pagar. O novo software utilizará o ambiente Windows. Apesar de não existir integração entre todos os softwares utilizados na empresa, a formalização fazia com que ela conseguisse integrar algumas informações e evitar duplicidade de informações ou perdas das mesmas. A definição das funções de cada área, consequiência do programa da qualidade implantado na empresa, também auxiliou nesta tarefa.

Todas as obras têm em media quatro computadores. Elas não estão ligadas online com o escritório central, mas atualizam seus informações duas vezes ao dia, pela manhã e a tarde através de um modem. O BPM é feito eletronicamente pela obra usando o software de suprimentos acessado através de um modem. A aprovação deste documento também é feita diretamente no computador pelo GGO.

Outro documento que se encontra disponível eletronicamente é o Pedido Externo de Fornecimento - PEF. Este documento é gerado pelo departamento de suprimentos ao se efetuar a compra do material. Para cada fornecedor é gerado um PEF, indicando a obra, 
descrição do material, quantidade, fornecedor e data de entrega. A baixa da nota fiscal é feita eletronicamente através do PEF quando o material recebido é aceito pela obra. Para realizar o pagamento o departamento de contas a pagar compara a nota fiscal com o PEF gerado.

Na obra o almoxarife faz o controle de estoque diretamente no computador via software.

\subsection{Fluxo de Informações}

Como nos outros casos, neste item descreve-se as etapas que a requisição deverá percorrer até que o material comprado seja entregue na obra. Este fluxo é representado na Figura 15, Figura 16, Figura 17 e Figura 18 através dos DFD.

- Requisição do material e aprovação da requisição: no inicio da obra a identificação das suas necessidades se faz em função do primeiro cronograma enviado pela área de planejamento. Para as requisições seguintes utiliza-se o planejamento e o cronograma da produção e o cronograma de materiais. A requisição de materiais é feita mensalmente através do BPM. Como já foi explicado, este documento é gerado eletronicamente pelo GO e aprovado eletronicamente pelo GGO.

- Solicitação da cotação para o fornecedor: aprovada a requisição pelo GGO o chefe de suprimentos recebe a mesma e, antes de repassá-la para seus compradores, a revisa para verificar a existência de algum erro nas especificações ou se as mesmas não estão claras. No caso em que as informações não estejam totalmente claras nem completas, ele faz um relatório e manda a requisição de volta para a obra.

O procedimento para abrir uma concorrência é o seguinte: se analisam os BPM de distintas obras e se agrupam os materiais iguais para fazer uma compra conjunta. A compra é por "pacote" mas o quadro de concorrência é por obra. Quando se abre 
uma concorrência o sistema "puxa" o maior e o menor preço já pago. Além disso, em cada BPM aparece o preço cotado pela obra.

O sistema emite um quadro resumo agrupando materiais iguais e obtendo a quantidade total para esse material. Com esse quadro se faz o pedido de cotação.

- Cotação: o quadro anterior é enviado aos fornecedores e eles devem colocar um preço unitário por cada material. A comunicação entre o escritório central e o fornecedor é feita por telefone ou fax.

- Aprovação da cotação: o gerente de suprimentos tem autonomia para decidir sobre a compra mas no caso de compras grandes geralmente consulta a diretoria de construção.

- Formulação do Pedido Externo de Fornecimento - PEF: uma vez aprovada a cotação o departamento de suprimentos confirma a compra junto ao fornecedor e elabora um documento eletrônico chamado PEF. No caso em que se aprovem dois ou mais fornecedores para uma requisição, se faz um PEF para cada fornecedor.

Nele coloca-se os dados do fornecedor, descrição do material, quantidade, obra, data de entrega, forma de pagamento, etc. Este documento é enviado às obras e ao contas a pagar e fica acessível através da rede.

- Entrega e recebimento do material na obra: existem materiais que têm uma única entrega enquanto que outros várias. No caso dos materiais com várias entregas geralmente a obra se comunica com o fornecedor e entrega um cronograma de entregas ou telefona para ele para programar as entregas. No momento da entrega cada material vem com nota fiscal. O material geralmente é recebido pelo almoxarife; somente para alguns materiais, como pias de mármore e portas de madeira, o engenheiro da obra recebe o material e verifica sua qualidade. Como já foi comentado, a empresa possui procedimentos de recebimento e controle que já 
existiam antes da certificação pela ISO 9002, mas foram adequados para a certificação.

Cada vez que se recebe um material na obra se cria um documento chamado Guia de Recebimento de Material - GDRM. Nesta guia se coloca os dados do material e fornecedor, quantidade e custo e se verifica que coincida com o PEF. Somente a quantidade pode não coincidir, quando o material é entregue por partes, em várias entregas. Neste caso, a quantidade total do material deve coincidir com a quantidade do PEF.

Caso exista alguma não-conformidade, está é registrada. As não-conformidades são identificadas com base em requisitos de conformidade documentados estabelecidos pela empresa. Estes requisitos também aparecem no contrato com o fornecedor.

Para cada não-conformidade se abre um documento chamado Ocorrência de Produto Não-Conforme - OPNC. Neste documento se coloca o problema e a solução adotada. Este documento é repassado ao GGO para que avalie se o problema é um problema pontual ou se está também acontecendo em outras obras.

Em resumo, os documentos para o recebimento de materiais são a GDRM, a nota fiscal e o PEF. Caso esteja conforme, se libera o pagamento no PEF e se envia a nota fiscal ao contas a pagar. Quem dá aprovação final do recebimento é o GO.

- Distribuição de materiais: a distribuição dos materiais no canteiro é realizada pelas equipes de produção interessadas. A programação dos equipamentos para a movimentação dos materiais na obra é feita segundo as necessidades da obra.

A seguir apresentam-se nas Figura 15, Figura 16, Figura 17 e Figura 18 os DFD da Empresa C. Na Tabela 11 consta o seu dicionário de dados. 


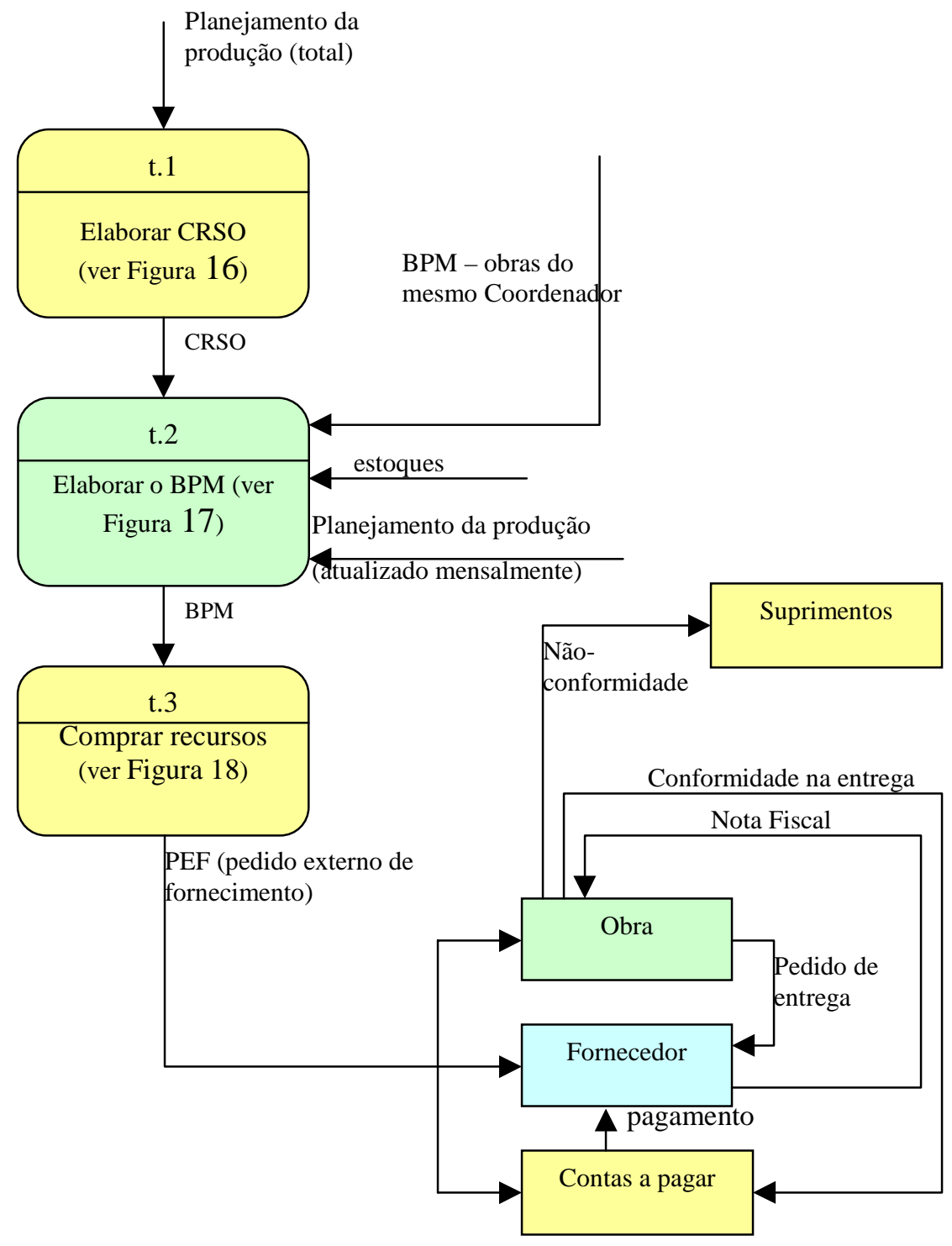

CRSO: $\quad$ Cronograma de Suprimentos Semestral.

BPM: $\quad$ Boletim de Programação Mensal de Materiais.

PEF: $\quad$ Pedido Externo de Fornecimento.

GGO: $\quad$ Coordenador de Obras.

Figura 15.- DFD da Empresa C 


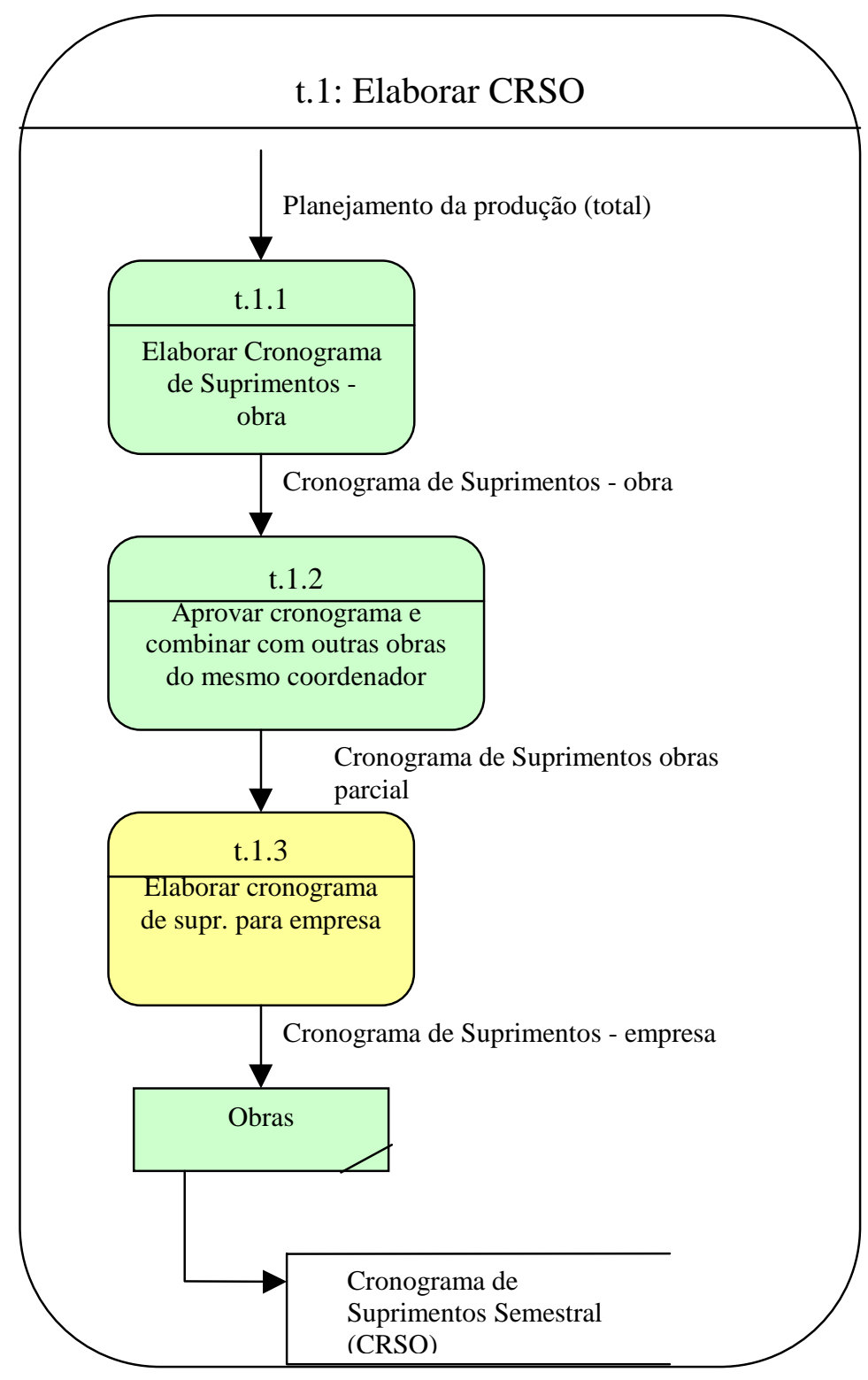

Figura 16.- DFD Empresa C, detalhe do processo t.1 


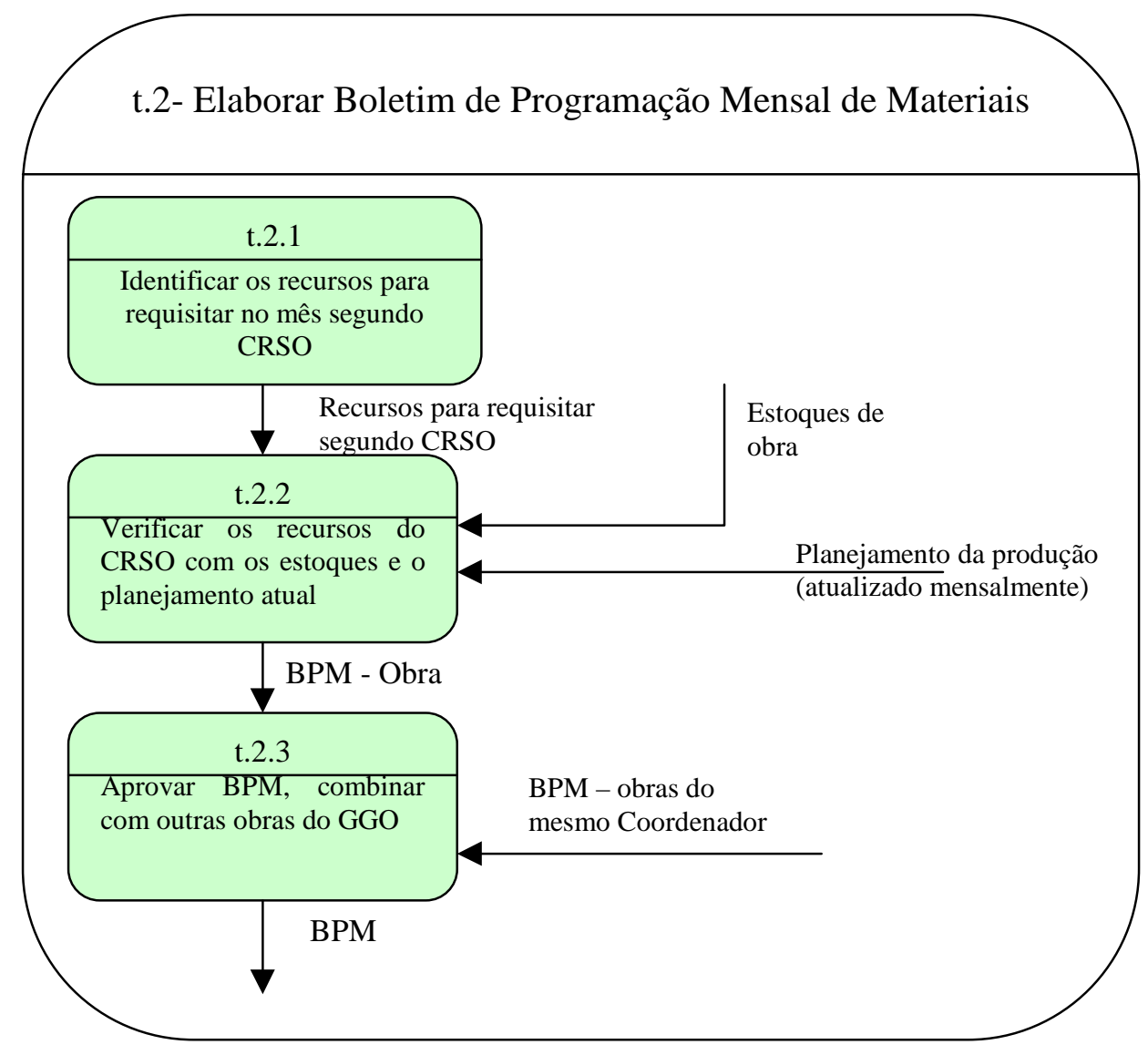

Figura 17.- DFD empresa $C$, detalhe do processo t.2 


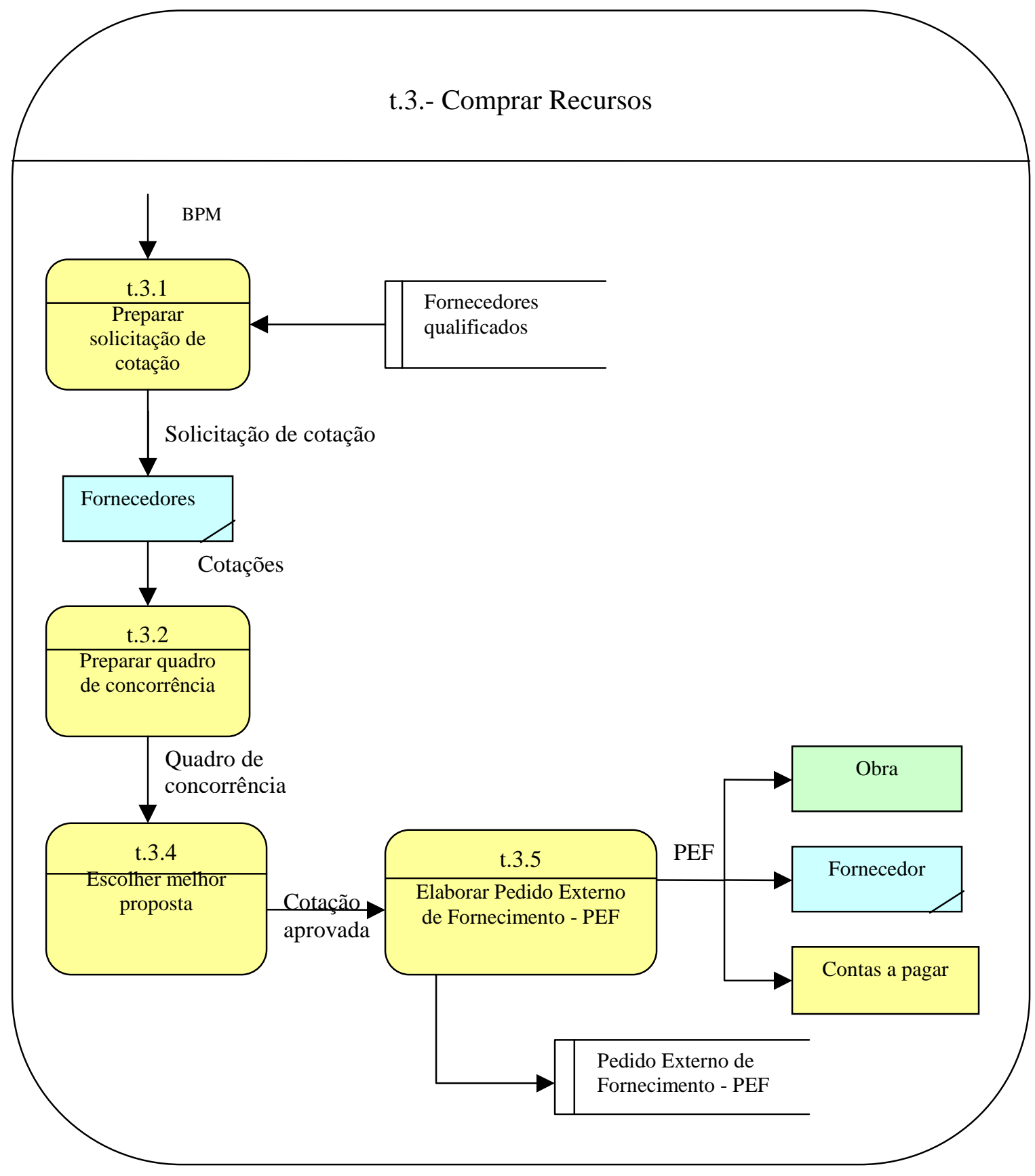

Figura 18.- DFD empresa C, detalhe do processo t.3 
Tabela 11.- Dicionário de Dados (Empresa C)

\begin{tabular}{|c|c|}
\hline Informação & Dicionário de Dados \\
\hline $\begin{array}{l}\text { Planejamento da produção } \\
\text { (total) }\end{array}$ & $\begin{array}{l}\text { Refere-se ao documento onde se encontram as informações } \\
\text { sobre o planejamento total da obra. }\end{array}$ \\
\hline $\begin{array}{l}\text { Cronograma de suprimentos - } \\
\text { obra }\end{array}$ & Refere-se ao cronograma de materiais de uma obra específica. \\
\hline $\begin{array}{l}\text { Cronograma de suprimentos - } \\
\text { obras parcial }\end{array}$ & $\begin{array}{l}\text { Refere-se ao cronograma de materiais para as diferentes obras } \\
\text { de um mesmo coordenador. }\end{array}$ \\
\hline $\begin{array}{l}\text { CRSO - Cronograma de } \\
\text { suprimentos Semestral }\end{array}$ & $\begin{array}{l}\text { Refere-se ao documento da empresa elaborado em função dos } \\
\text { cronogramas de materiais de todas as obras. }\end{array}$ \\
\hline $\begin{array}{l}\text { BPM - Boletim de } \\
\text { Programação Mensal de } \\
\text { Materiais }\end{array}$ & $\begin{array}{l}\text { Refere-se à requisição de materiais aprovada pelo } \\
\text { coordenador. }\end{array}$ \\
\hline $\begin{array}{l}\text { PEF- Pedido Externo de } \\
\text { Fornecimento }\end{array}$ & $\begin{array}{l}\text { Refere-se ao pedido de compra. Nele especifica-se: dados do } \\
\text { fornecedor; nome do produto; quantidade; custo unitário e } \\
\text { total da compra; condições de pagamento; identificação da } \\
\text { obra; local de entrega; data de entrega e outras informações } \\
\text { que fazem parte da compra. }\end{array}$ \\
\hline $\begin{array}{l}\text { Recursos a requisitar segundo } \\
\text { CRSO }\end{array}$ & $\begin{array}{l}\text { Refere-se à identificação dos recursos necessários à obra } \\
\text { segundo o CRSO. }\end{array}$ \\
\hline Solicitação da cotação & $\begin{array}{l}\text { Refere-se à informação que será enviada ao fornecedor para } \\
\text { solicitar a cotação. Contem os seguintes dados: nome do } \\
\text { material; quantidade, local de entrega, data de entrega. }\end{array}$ \\
\hline Cotação & $\begin{array}{l}\text { Refere-se ao documento que envia o fornecedor indicando o } \\
\text { nome do material, quantidade, preço unitário, preço total e } \\
\text { condições de pagamento e entrega. }\end{array}$ \\
\hline Quadro de concorrência & $\begin{array}{l}\text { Refere-se ao documento feito pelo setor de suprimentos onde } \\
\text { se colocam os dados das cotações enviadas para um mesmo } \\
\text { produto. }\end{array}$ \\
\hline Cotação Aprovada & $\begin{array}{l}\text { Refere-se à informação que indica o(s) nome do(s) } \\
\text { fornecedor(es) do(s) (qual) quais se comprará o produto. }\end{array}$ \\
\hline Pedido de entrega & $\begin{array}{l}\text { Refere-se ao pedido que faz a obra ao fornecedor solicitando- } \\
\text { lhe a entrega do material em uma data específica. }\end{array}$ \\
\hline Conformidade na entrega & $\begin{array}{l}\text { Refere-se à informação onde se aprova a entrega de material } \\
\text { na obra. }\end{array}$ \\
\hline Entrada de material na obra & $\begin{array}{l}\text { Refere-se à notificação às equipes encarregadas da chegada do } \\
\text { material na obra. }\end{array}$ \\
\hline Não-conformidade & $\begin{array}{l}\text { Refere-se à informação que indica uma não-conformidade na } \\
\text { entrega. }\end{array}$ \\
\hline Nota Fiscal & $\begin{array}{l}\text { Refere-se ao documento que indica a quantidade total a pagar } \\
\text { pela entrega realizada. }\end{array}$ \\
\hline Pagamento & Refere-se ao pagamento feito pela empresa ao fornecedor. \\
\hline
\end{tabular}




\section{Capítulo 7 Identificação das Diretrizes para a Elaboração do Modelo de Gestão de Fluxo de Informação}

Este capítulo está dividido em duas partes. Na primeira parte são analisados os fluxos de informação nas empresas construtoras estudadas, buscando identificar suas virtudes e falhas. Com base nesta análise são identificadas as principais diretrizes que auxiliem as empresas na otimização de seus fluxos de informação referentes à gestão de materiais. Está análise é feita segundo o método proposto no Capítulo 5.

Já na segunda parte discute-se a forma como o sistema proposto deve ser avaliado em busca de uma melhoria continua e, além disso, analisa-se a possibilidade de inovar estes fluxos através de enfoques como o estabelecimento de parcerias, o uso de produtos normalizados, o uso da Internet como meio de comunicação entre a empresa e seus fornecedores e o uso dos códigos de barras.

\subsection{Análise dos Casos e Identificação das Diretrizes}

Tendo-se apresentado as principais características das formas como as empresas estudadas organizam seus fluxos de informações, este item objetiva analisar estes fluxos tratando de identificar os fatores chaves que sirvam para formular as diretrizes tema desta pesquisa.

Embora as três empresas estudadas tivessem formalizados seus processos para a requisição de materiais, puderam-se identificar problemas comuns a todas elas, quais sejam:

- Informações imprecisas ou incompletas: em todas as empresas estudadas existiam problemas de precisão e clareza nas requisições dos materiais. Isso dificultava o trabalho do setor de compras e as vezes ocasionava compras erradas. Geralmente, a requisição saía da obra mal especificada, passava pela aprovação do coordenador 
para depois passar ao comprador ou chefe da área de suprimentos, que era a pessoa que as vezes conseguia identificar os erros devido à sua experiência ou à falta de dados para poder solicitar a cotação.

- Duplicidade de informações: nas três empresas construtoras, a quantificação de alguns materiais fazia-se pelo menos duas vezes, ao se elaborar o orçamento e ao se fazer as requisições. Outro caso era o dos gastos do mês; na empresa A, por exemplo, tanto o departamento de orçamentos e controle de custos quanto o de contas a pagar fazia o controle dos gastos da obra. A duplicidade de arquivos contendo informações similares também era comum na empresa A, onde existiam informações arquivadas em diversos departamentos devido à falta de uma base de dados que integrasse as informações entre eles.

- Perdas da informação: um problema identificado nas três empresas foi a dificuldade que se tinha para registrar as mudanças que aconteciam durante o transcurso da obra. As vezes um material era trocado por um similar mas a troca se fazia sem se registrar a mudança. Similarmente, devido às modificações do projeto mudavam-se quantidades na obra sem modificar o orçamento inicial e nem registrar as mudanças. Como conseqüência, além dos problemas que isso podia ocasionar a uma obra em particular, existia um prejuízo para toda a empresa. Não existia um retorno de informação para obras futuras, a empresa não aprendia com seus erros, mesmo com os que se repetiam constantemente.

- Dificuldade em obter informações oportunas: dado que a empresas A e C não tinham uma base de dados que integrasse as informações dos diversos departamentos, existia nelas uma dificuldade de ter acesso a estes dados de uma forma rápida. Já a empresa $\mathrm{B}$ apresentava a vantagem de ter um sistema que 
integrava estes dados e os colocava em uma base de dados comum, a qual facilitava a recuperação dos mesmos de uma maneira rápida e eficiente.

Para os problemas apresentados, puderam-se identificar algumas causas que são apresentadas na Tabela 12 .

Tabela 12.- Causas dos problemas nos fluxos de informação nas empresas estudadas

\begin{tabular}{|c|c|}
\hline $\begin{array}{l}\text { Problemas } \\
\text { Identificados }\end{array}$ & Causas Identificadas \\
\hline $\begin{array}{l}\text { Informações imprecisas } \\
\text { ou incompletas }\end{array}$ & $\begin{array}{l}\text { - Falta de documentos, sejam sob a forma de papel ou } \\
\text { eletrônicos, que subsidiem a troca de informações } \\
\text { (formalização). Estes documentos devem servir de controles em } \\
\text { cada uma das etapas pelas quais circula a informação. } \\
\text { - Responsabilidades mal ou pobremente definidas. }\end{array}$ \\
\hline $\begin{array}{l}\text { Duplicidade de } \\
\text { informações }\end{array}$ & $\begin{array}{l}\text { - Falta de integração de informações entre as distintas áreas. } \\
\text { - Funções ou departamentos mal definidos. }\end{array}$ \\
\hline Perdas da informação & $\begin{array}{l}\text { - } \quad \text { Falta de capacidade para processar informação. } \\
\text { - Falta de regras que definam o que fazer ante a ocorrência de } \\
\text { eventualidades (formalização). }\end{array}$ \\
\hline $\begin{array}{l}\text { Dificuldade em obter } \\
\text { informações oportunas }\end{array}$ & $\begin{array}{l}\text { - } \quad \text { Falta de TI que subsidiem a integração na empresa. } \\
\text { - Morosidade do sistema informatizado ou das pessoas } \\
\text { - Sesponsáveis pela tomada de decisões. } \\
\text { - Sistemas de informação mal ou pobremente definidos. }\end{array}$ \\
\hline
\end{tabular}

Pensando-se nos fluxos de informação como sendo compostos de dois elementos principais, estrutura (forma ou caminho) e informação, e relacionando-se estes dois elementos com as causas anteriormente colocadas, pode-se perceber que algumas delas estão relacionadas com a estrutura dos fluxos de informações enquanto que outras estão relacionadas com a informação que circula (ver Tabela 13).

Sendo que para analisar a informação que circula pelo sistema deve-se analisar as etapas pelas quais estas informações serão transformadas (processadas). Dividiu-se a análise em duas categorias como foi estabelecido no Capítulo 5: 
i) Análise da estrutura dos fluxos de informações (parte física do sistema)

ii) Análise das etapas (processos) pelas quais é processada a informação.

A seguir aprofunda-se em ambos casos.

Tabela 13.- Relação das causas dos problemas identificados com a forma dos fluxos de informação ou com a informação que por eles circula.

\begin{tabular}{|c|c|c|}
\hline Causas dos Problemas & $\begin{array}{c}\text { Estrutura (forma) dos } \\
\text { fluxos de Informação }\end{array}$ & $\begin{array}{c}\text { Informação } \\
\text { que circula }\end{array}$ \\
\hline Documentos & & $\mathrm{X}$ \\
\hline Definição de responsabilidades & $\mathrm{X}$ & $\mathrm{X}$ \\
\hline Integração & $\mathrm{X}$ & \\
\hline Capacidade para processar informação & $\mathrm{X}$ & $\mathrm{X}$ \\
\hline Regras - Formalização & $\mathrm{X}$ & $\mathrm{X}$ \\
\hline Tecnologia da Informação - TI & $\mathrm{X}$ & $\mathrm{X}$ \\
\hline $\begin{array}{c}\text { Perfil da pessoa responsável pela execução de } \\
\text { cada etapa pela qual circula a informação }\end{array}$ & $\mathrm{X}$ & \\
\hline
\end{tabular}

\subsubsection{Análise da estrutura dos fluxos de informações (parte física do sistema)}

Como foi comentado no Capítulo 5, para a análise da estrutura dos fluxos de informação abordaram-se aspectos ligados à estrutura organizacional, à análise de funções, à identificação dos envolvidos no processo de tomada de decisões e às tecnologias de informação que suportam estes fluxos, com a finalidade de analisar o caminho por onde circulam as informações.

Começando pela configuração da estrutura organizacional pode-se dizer que as empresas $\mathrm{A}$ e $\mathrm{B}$ tinham uma de tipo funcional enquanto que a empresa $\mathrm{C}$ apresentava uma configuração funcional com uma marcada tendência à especialização por projeto.

Nesta última empresa, cada empreendimento tinha bastante independência para a tomada de decisões a respeito de sua obra. As empresas A e B eram de médio porte, já a C pode-se catalogar como de grande porte. 
Quanto ao grau de centralização a ordem era inversa, a empresa A apresentava um grau de centralização muito forte focalizado no seu diretor técnico enquanto que no outro extremo encontrava-se a empresa $\mathrm{C}$ na qual os encarregados de cada departamento tinham maior poder para tomar decisões. Na empresa B a situação era intermediária.

A formalização era maior na empresa C, certificada pela ISO 9002, a qual tinha muito bem definidas suas funções, procedimentos e especificações. Além disso, seus fluxos de informações eram respaldados por documentos especialmente desenhados. Por outro lado, a empresa B estava em processo de formalização e como foi comentado tinha um departamento especialmente criado para a elaboração de especificações e procedimentos. Já a empresa A era a que apresentava menor grau de formalização.

Quanto ao grau de complexidade espacial, as três empresas construtoras tinham uma complexidade espacial elevada devida à dispersão geográficas das obras. No entanto, pode-se dizer que a empresa $\mathrm{C}$ era a que tinha maior grau de complexidade espacial pois tinha obras em duas cidades, São Paulo e Rio de Janeiro. Por outro lado, quanto à complexidade vertical e horizontal, todas elas apresentavam uma complexidade similar, sendo que a empresa $\mathrm{C}$ possuía uma complexidade ligeiramente maior.

Na Tabela 14 resumem-se as principais características da estrutura organizacional das empresas construtoras estudadas.

Analisando as três empresas em relação ao seu ambiente, observou-se que em todas elas a incerteza no ambiente era introduzida por agentes externos. A economia do país, por exemplo, pode ser considerada como um agente externo que induz incerteza, já que a instabilidade da economia repercute diretamente na cadeia de suprimentos. Já os fornecedores são outro tipo de agentes externos que podem introduzir incertezas no ambiente. 
Tabela 14.- Quadro comparativo das Empresas A, B e C em relação às características de sua estrutura organizacional

\begin{tabular}{|c|c|c|c|}
\hline Características & Empresa A & Empresa B & Empresa C \\
\hline Porte & Médio & Médio & Grande \\
\hline Configuração & Funcional & Funcional & $\begin{array}{c}\text { Híbrida: Funcional + } \\
\text { por projeto }\end{array}$ \\
\hline $\begin{array}{c}\text { Grau de } \\
\text { formalização }\end{array}$ & Baixo & Médio & Alto \\
\hline $\begin{array}{c}\text { Grau de } \\
\text { centralização }\end{array}$ & Alto & Médio & Baixo \\
\hline $\begin{array}{c}\text { Grau de } \\
\text { complexidade }\end{array}$ & Médio & Médio & Alto \\
\hline
\end{tabular}

Quanto à tecnologia, pode-se dizer que na construção de edifícios ela é bastante interdependente, o que faz crescer a demanda pelo processamento de informações (ver Capítulo 3). Assim sendo, a complexidade do produto, a incerteza existente no ambiente e a interdependência na tecnologia fazem com que a demanda por processamento de informações, na construção de edifícios, seja muita elevada.

Das três empresas estudadas a que melhor conseguiu conciliar sua capacidade de processamento de informações com a demanda por processamento de informações existente foi a empresa C. Esta empresa utilizou a formalização, através de especificações e procedimentos, tanto para diminuir a demanda pelo processamento de informações quanto para incrementar sua capacidade de processamento. Através dos procedimentos padronizados, permitiu que o processamento de informações pudesse também ser realizado por hierarquias inferiores, liberando assim as hierarquias superiores para outras tarefas.

Por outro lado, a empresa $\mathrm{C}$ diminuiu a demanda do processamento de informações através do método chamado por Galbraith de "criação de grupos auto-contidos" (ver capitulo 3.2.1, item (ib)). Nesta empresa, cada empreendimento pode ser considerado um grupo que tem seus próprios recursos para cumprir suas metas. Embora nela 
existiam departamentos comuns a toda a empresa, como era o caso do suprimentos, a política da empresa era a de outorgar a autonomia necessária a cada obra para resolver seus problemas. Desta forma, as hierarquias superiores tinham mais tempo para resolver problemas estratégicos da empresa, não se envolvendo com problemas operacionais ou táticos.

Analisando a função do departamento de suprimentos nas três empresas, pode-se observar que somente a empresa $\mathrm{C}$ utilizava este departamento para obter economias em compras em grande escala. Ela estabelecia semestralmente um cronograma de compras para os materiais que podiam ser comprados em grande volume. Isso era possível já que para a empresa o planejamento da produção era muito importante e o grau de formalização muito grande. Já as outras duas empresas utilizavam esta área como uma central de compras, as obras podendo mandar suas requisições diariamente, o que dificultava agrupar pedidos de compras.

Por outro lado, foi interessante notar que as empresas A e B, onde as responsabilidades de cada empreendimento ficavam repartidas entre o escritório principal e a obra (ver matrizes de responsabilidades na Tabela 6, Tabela 8 e Tabela 10), apresentavam menos flexibilidade que a empresa $\mathrm{C}$, onde estas responsabilidades se concentravam basicamente na obra.

O que usualmente acontecia nas empresas $\mathrm{A}$ e $\mathrm{B}$ era que o engenheiro residente precisava muitas vezes das aprovações de outros departamentos para resolver alguns tipos de problemas que diziam respeito à sua obra. Na empresa $\mathrm{B}$, por exemplo, como somente se podiam requisitar produtos que estivessem no orçamento, ao acontecer uma mudança na obra, esta informação tinha que voltar para o departamento de orçamentos 
para que as modificações fossem incluídas no orçamento e somente assim conseguia se fazer a requisição. Por conseqüência, o processo fazia-se moroso.

Já na empresa $\mathrm{C}$, o engenheiro responsável (GO) tinha um envolvimento maior com seu projeto, o qual começava antes do início da obra. Além da responsabilidade pela execução e controle de obra, ele era responsável pelo orçamento e pelo planejamento da obra e tinha maior poder para aprovar modificações que os seus homólogos das outras duas empresas (ver Tabela 10). Isso fazia com que cada obra tivesse mais flexibilidade com respeito à tomada de decisões.

Além disso, sendo que os problemas da obra são geralmente mais conhecidos pelo pessoal que nela trabalha, pode-se dizer que é mais adequado que as decisões da obra sejam tomadas por pessoas diretamente envolvidas. Sendo que elas têm a maior quantidade de informação, que são obtidas de modo mais rápido, isso as coloca em uma melhor posição para uma boa tomada de decisões.

Quanto ao sistema de informação das três empresas construtoras estudadas, pode-se afirmar que a que o tinha melhor estruturado era a Empresa C, seguida da Empresa B, a qual estava em uma etapa de transição. Cabe ressaltar que estas duas empresas apresentam sistemas de informação diferenciados comparados às empresas em geral do setor. Já a empresa A pode ser tomada como uma empresa padrão para o setor.

É interessante notar que, apesar de a empresa C utilizar softwares menos integrados e desenvolvidos que os da empresa $\mathrm{B}$, o seu sistema de informação apresentava uma estrutura que favorecia o fluxo eficiente de informações. O fato de ter formalizado e planejado seus processos faziam com que os fluxos acontecessem de uma forma mais organizada. Aqui conclui-se que não basta uma TI para conseguir otimizar os fluxos de informações, pois uma boa gestão destas tecnologias é vital para o seu sucesso. 
Com base na análise da estrutura dos fluxos de informações relativos à gestão de materiais, a seguir apresentam-se as principais conclusões desta análise:

1. Sendo que a formalização aumenta a capacidade de processamento de informações e ao mesmo tempo diminui a demanda por processamento de informações, pode-se considerá-la um elemento importante para a racionalização dos fluxos de informação ligados à gestão de materiais. Constatou-se que a empresa construtora que apresentava maior grau de formalização tinha também seus fluxos de informações mais organizados que as outras duas empresas.

Como parte deste processo de formalização, a empresa também deve definir claramente as suas funções e os perfis e as responsabilidades de seus funcionários. Cabe recordar que eles são os responsáveis pelo processamento de informações na empresa e, portanto, a qualidade das informações que circulam vai depender em grande parte de seus desempenhos.

2. Como os estudos mostraram que quanto maior a distribuição de responsabilidades pela gestão de materiais por toda a empresa menor a flexibilidade para a tomada de decisões da obra, sugere-se que, pelo menos para as construtoras de médio a grande porte, cada obra tenha a autonomia suficiente para tomar decisões que lhe concernem. Para tanto, uma estrutura organizacional com configuração do tipo híbrido: funcional \& projetos seria a mais adequada, outorgando a cada empreendimento os recursos necessários para atender suas necessidades.

Assim, a maioria das funções de uma determinada obra devem ficar sob a responsabilidade do pessoal dela encarregado. Com isso, passa a existir um maior envolvimento do engenheiro da obra e de sua equipe não somente no que concerne a execução mas também o desenvolvimento dos relatórios e documentos necessários 
para subsidiar o gerenciamento de sua obra. Desta forma, o engenheiro responsável adquire o conhecimento necessário para poder tomar as decisões mais acertadas sem precisar depender de outros departamentos da empresa, combatendo a morosidade no sistema, tornando-o mais eficiente.

Uma contrapartida disso é a exigência de um engenheiro melhor formado, dotado de competências que o habilitem a assumir essas novas responsabilidades.

3. Quanto ao departamento responsável pela função suprimentos, foi constatado que, quando o mesmo não está devidamente estudado nem desenhado, acaba atuando simplesmente como uma central de compras, ficando sujeito a requisições diárias das obras, o que o impede de melhor gerenciar suas compras.

Por outro lado, as empresas que estruturam seu departamento de suprimentos podem potencializar as suas atividades. Assim, este departamento pode conseguir melhores preços agrupando compras ou pode passar a pesquisar novos produtos e fornecedores, participando com esse conhecimento em etapas iniciais do empreendimento. Por último, pode passar a cadastrar e avaliar seus fornecedores. Desta forma, o departamento de suprimentos cumpre com outras funções além da de compra de materiais, agregando valor à gestão de materiais.

4. Quanto à TI pode-se afirmar que, uma vez que ela elimina distâncias e facilita a troca e o envio de dados e informações, o seu uso tem potencial para racionalizar e agilizar os fluxos de informações. No entanto, para obter um sucesso real, estas tecnologias precisam ser bem gerenciadas.

Considerando o fato de as informações geralmente encontrarem-se dispersas pelos diferentes departamentos da empresa, através de uma rede, um software e uma base de dados pode-se conseguir integrar os diversos departamentos e fazer com que eles 
tenham acesso a informações de outras áreas. É importante que os softwares utilizados na empresa sejam compatíveis entre si para não prejudicar o compartilhamento de informações.

As bases de dados normalizam formatos e arquivos, correlacionam dados e informações comuns, sincronizam cópias atualizadas de arquivos e reduzem redundâncias de dados.

Uma nova opção que está aparecendo com a Internet, alternativamente aos softwares adquiridos de forma convencional (comprados e feitos sob pedido) pela empresa, são os softwares alugados. Sendo que os "pacotes" que integram toda a empresa são em geral caros para empresas de pequeno porte, esta pode ser uma boa opção para integrar as informações dos seus empreendimento. Entretanto, esta nova opção está sendo difundida e, como foi comentado no Capítulo 4, ainda existe uma carência de padrões no setor que propicie sua maior difusão.

Quanto à integração da empresa com seus fornecedores, apesar de as empresas estudadas não utilizarem no momento da pesquisa outras tecnologias além do telefone ou fax para com elas se comunicarem, acredita-se que em um futuro próximo, devido ao aparecimento da Internet, este panorama deve mudar.

Como foi comentado no Capítulo 4 o comércio eletrônico on-line de produtos do setor já é uma realidade e espera-se que nos próximos anos converta-se na forma convencional para realizar transações comerciais. Porém, não se deve esquecer que isso dependerá da decisão das empresas do setor pela definição e utilização dos mesmos padrões de identificação que propiciem esta troca de informações através da Internet. Como conseqüência, isso deve-se tornar uma prioridade para o setor. 
Independentemente do tipo de TI, é indispensável que a empresa organize e otimize seus fluxos de informações antes de implementar as novas tecnologias. As vezes, as novas TI fazem com que algumas rotinas dos fluxos de informação já não sejam necessárias, sendo importante conhecer as suas capacidades para poder potencializar seus benefícios e implementá-las da maneira mais adequada. O questionamento da estrutura organizacional da empresa, especialmente de sua estrutura de decisão, deve também ser feito no momento de se escolher e implantar uma TI.

Em resumo, as principais diretrizes que se conclui da análise da estruturas dos fluxos de informações das empresas investigadas são:

- a formalização da empresa é um importante elemento para a racionalização dos fluxos;

- a autonomia das obras para tomar decisões quanto à gestão de materiais aumenta a eficiência do sistema. Para tanto, uma configuração do tipo híbrida \& funcional é a mais adequada já que outorga a cada empreendimento os recursos necessários para conseguir esta autonomia;

- a estruturação e o planejamento do setor de suprimentos permite que ele cumpra funções outras que a de simples "comprador de materiais";

- as TI têm potencial para racionalizar e agilizar os fluxos de informação, desde que sejam adequadas à empresa e sejam corretamente gerenciadas.

\subsubsection{Análise das etapas pelas quais é processada a informação}

Continuando com a análise dos fluxos de informação, neste item analisa-se a informação que circula pela estrutura anteriormente estudada. A idéia é a de definir as etapas (processos) segundo as quais circula a informação referente à gestão de materiais 
e a de identificar os principais requisitos que cada uma delas deve apresentar com a finalidade de garantir a qualidade da informação que circula.

Como foi percebido nas empresas estudadas e no levantamento bibliográfico, as principais etapas identificadas pelas quais a informação deverá percorrer até voltar à obra convertida no material necessitado são: identificação da necessidade; elaboração da requisição; aprovação da requisição; formulação da solicitação da cotação; elaboração da cotação; escolha do fornecedor; compra e formulação do pedido de compra; recepção do produto; e pagamento.

Cada uma destas etapas representa um processo, que dependerá de vários elementos para sua boa execução (ver Figura 8), quais sejam:

- dados de entrada;

- outras informações ou dados;

- $\quad$ agente ou mecanismo que processa a informação.

Estando definida a estrutura ou caminho que estas informações deverão percorrer, a única forma de garantir a qualidade do resultado final é assegurar a geração de informações com qualidade em cada uma das etapas, já que a informação de saída de um processo servirá de entrada para o processo seguinte.

Em resumo, neste item pretende-se desenhar um fluxo de informação modelo para a gestão de materiais com base nos casos estudados e no levantamento bibliográfico apresentado. Este desenho deverá contemplar as funções envolvidas ou participantes, a documentação mínima necessária e os meios de comunicação mais adequados que dêem suporte ao sistema. 
A seguir, analisa-se cada uma das etapas ou processos antes mencionados. Através da definição e da delimitação de cada etapa, identifica-se os principais requisitos para garantir a qualidade da informação em cada uma delas.

\subsubsection{Identificação da necessidade}

Embora o ponto de partida do fluxo de informações relativas à gestão de materiais inicia-se na etapa do projeto, quando se define grande parte dos materiais, para efeito do modelo de gestão toma-se a identificação da necessidade para a produção como ponto de inicio deste fluxo.

Esta etapa inicia-se quando "alguém" identifica a necessidade de um recurso para atender a uma demanda da produção. Esta identificação geralmente se dá no canteiro, porém, as vezes, geralmente no início da obra, quem “dispara” o processo é uma função do escritório central, como o responsável pelo de orçamentos ou pelo planejamento.

A identificação oportuna e precisa da necessidade do material vai estar fortemente relacionada a documentos e informações de outras áreas. No entanto, é importante lembrar que a qualidade e a confiabilidade destas informações dependem das pessoas encarregadas pela sua elaboração.

Baseando-se na bibliografia pesquisada e nos estudos de caso desenvolvidos, os principais documentos requeridos para identificar oportunamente as necessidades da obra são:

- planejamento confiável da produção: como foi mencionado na parte teórica desta dissertação (ver item 2.3.2), o planejamento consiste na fixação de objetivos para a produção sobre o que se deve produzir, quando, como e por quem. Sem um planejamento confiável da produção é praticamente impossível ter um bom ponto de 
partida e identificar adequadamente os materiais que são necessários ao longo do tempo.

O planejamento da produção deve ser feito inicialmente a partir do orçamento, quantificação e projetos existentes, com destaque para os projetos dos processo ou "para produção". Nele também deve-se considerar fatores tais como a forma de contratação da mão-de-obra, e o tipo de tecnologia a ser utilizada, dentre outros. Como na maioria das vezes no inicio da obra não estão definidos muitos fatores, o planejamento inicial deve assumir os dados que não se disponha, com base em índices de obras anteriores da empresa, e deve atualizar este planejamento inicial a medida que apareçam novos condicionantes e informações.

Das três empresas estudadas, somente na empresa C o planejamento da produção era uma atividade que se realizava com seriedade para ser utilizado e atualizado durante toda a obra como um instrumento para a gestão de materiais. Nas outras duas, o planejamento era deixado a critério e experiência do engenheiro responsável pela obra.

- Cronograma das necessidades dos materiais: este deve ser elaborado a partir do planejamento da produção e da quantificação dos recursos. A idéia é determinar em função do tempo quais são os materiais que serão necessários para cumprir com o planejamento da produção. Tendo este cronograma e conhecendo o tempo que se demora desde a requisição do material até que o mesmo seja entregue na obra, podese estabelecer as datas para iniciar as requisições dos materiais.

É importante lembrar que dependendo do material existem diferentes tempos para iniciar a requisição. Como foi explicado na Tabela 2, dependendo do produto, cada 
fornecedor tem um tempo de resposta, o qual se deve levar em conta para conseguir que o produto seja entregue no canteiro na data requerida.

- Inventário de materiais na obra: é importante se ter o registro das entradas e saídas de materiais para poder se identificar com antecipação os materiais que precisarão ser comprados. Nas empresas visitadas, o inventário era feito pelo almoxarife. Porém, nenhuma delas tinha um programa computadorizado integrado com os outros programas que auxiliasse nesta tarefa. No entanto, em todas elas o inventário era realizado em um computador com auxilio de uma folha de cálculo ou de um processador de textos.

Como já foi colocado, é também importante definir as pessoas responsáveis pela elaboração destes documentos. Nos casos apresentados encontrou-se que geralmente o planejamento estava sob a responsabilidade do engenheiro da obra. Por outro lado, o cronograma de materiais não era um documento que existia em todas as empresas. Das três empresas visitadas, somente a empresa C fazia um cronograma confiável de materiais, o qual era atualizado quando existiam mudanças no planejamento; este estava sob responsabilidade do gerente da obra (GO).

Portanto, sendo o planejamento da produção e o cronograma de materiais documentos indispensáveis para garantir a eficiência na gestão de materiais, é recomendável que eles fiquem sob a responsabilidade do engenheiro responsável pela obra. Para garantir o uso destes documentos a empresa construtora deve constantemente cobrar a sua atualização e uso dos responsáveis. $\mathrm{Na}$ empresa $\mathrm{C}$, por exemplo, estes documentos eram indispensáveis para a compra de materiais e, além disso, formavam parte do arquivo de documentos de todas as obras. A empresa exigia que todas as obras fizessem um 
planejamento da produção e um cronograma de materiais, já que a partir deles geravamse outros documentos e informes importantes para toda a empresa.

Já o inventario pode ser elaborado pelo almoxarife, já que ele é a pessoa quem tem acesso à maioria das informações sobre as entradas e saídas dos materiais, mas sempre deve ter uma aprovação do engenheiro responsável pela obra.

Garantindo a existência e a confiabilidade dos documentos anteriormente mencionados, a identificação oportuna da necessidade do material é facilitada, tornando-se praticamente uma conseqüência do uso correto dos mesmos.

No entanto, sendo que sempre existem modificações e situações imprevistas na obra, é recomendável que o responsável final por este processo seja o engenheiro residente, já que ele sempre estará melhor capacitado e em uma melhor posição para tomar a decisão mais acertada no caso de acontecer situações não previstas.

Na Figura 19 apresenta-se esquematicamente esta etapa do fluxo indicando as informações de entrada (documentos) e o agente processador deste processo. Já Tabela 15 resume as principais elementos desta etapa.

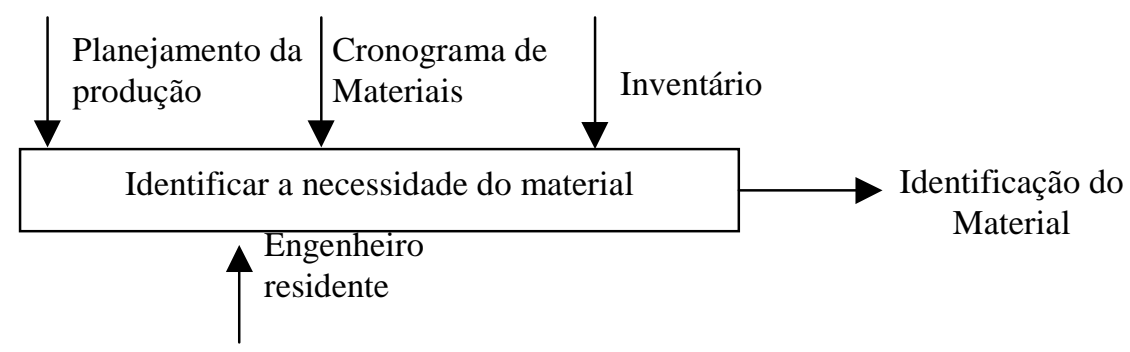

Figura 19.- Identificação da necessidade do material 
Tabela 15.- Identificação da necessidade

\begin{tabular}{lll}
\hline Agente ou mecanismo processador & $\bullet$ & engenheiro residente da obra \\
\hline Informações ou documentos & $\bullet$ & planejamento da produção; \\
adicionais & $\bullet$ & cronograma de materiais; \\
& $\bullet$ & inventário de materiais. \\
\hline & $\bullet$ & identificação do material: \\
& $>$ nome do material; \\
Informações de Saída & $>$ quantidade; \\
& $>$ data de compra; \\
\hline Receptor da informação & $>$ data de entrega. \\
\hline Meio de comunicação & $\bullet$ & eng. residente (obra) \\
\hline
\end{tabular}

\subsubsection{Elaboração da requisição}

Já identificados os materiais necessários o passo seguinte é o da elaboração da requisição. Sendo que normalmente a requisição é enviada para uma pessoa que não pertence à obra e que não participou da etapa anterior, é indispensável que os dados nela contidos sejam claros e precisos para evitar confusões e mal-entendidos no momento da compra.

Nas empresas estudadas, este processo era subsidiado por um formulário que tomava parte do programa de suprimentos. Nestas empresas, existia uma codificação para os materiais, sendo que a mesma coincidia com a codificação dos orçamentos. Na empresa B, por exemplo, o programa utilizado integrava o orçamento e suprimentos, fazendo com que cada obra somente pudesse requisitar os materiais que existissem no seu orçamento. Já nas outras empresas, apesar de o programa de orçamentos não ser integrado ao de suprimentos, a codificação dos materiais em ambos os programas eram iguais para evitar duplicidade de códigos.

Quanto à pessoa responsável pela formulação da requisição, constatou-se em todos os casos estudados que este era o engenheiro residente da obra. 
Quanto ao meio de comunicação utilizado, todas elas acessavam os programas de orçamentos diretamente desde a obra, com auxilio de um modem ou via Internet. No entanto, foi constatado que, apesar de todas as empresas possuírem programas que subsidiassem este processo, freqüentemente existiam problemas com as informações repassadas. Geralmente, quem identificava os problemas era o gerente de suprimentos.

Os principais dados encontrados em uma requisição de materiais foram: identificação do material; quantidade; local de entrega; condições de embalagem e transporte; data de entrega.

Em função dos problemas identificados nos casos estudados e das principais informações que deve possuir uma requisição, a seguir detalha-se cada uma destas informações de forma a evitar ambigüidades ou situações pouco claras no momento da compra:

- identificação do material: inclui o nome ou a descrição do material, especificações, detalhes do projeto e marca, caso especificada no projeto. É muito importante que a identificação do produto seja suficientemente clara para que o comprador possa consultar os fornecedores mais adequados para o produto pedido. Para tanto, muitas empresas codificam os materiais para sua identificação.

Pode-se encontrar dois casos segundo o material a se requisitar (ver Tabela 2):

(i) materiais provenientes de uma produção em massa: a maioria destes produtos são matérias primas ou componentes utilizados na obra. A existência de uma grande variedade do produtos no mercado dificulta a colocação de uma marca específica no momento da requisição porque na maioria dos casos o setor de suprimentos é quem decide finalmente de quem e de que marca vai comprar, 
muitas vezes em função do preço. Como critério adicional ao preço deve-se sempre observar o respeito ou conformidade do produto às normas.

Portanto, nos casos de matérias primas e componentes, que são produtos que muitas vezes têm função estrutural, é muito importante que existam especificações técnicas que acompanhem a identificação do material. Estas especificações podem ser próprias da empresa ou as especificadas pela ABNT mas em ambos os casos o pessoal da empresa deve estar familiarizado com elas e treinado para colocá-las em prática.

Por outro lado, existem também os produtos terminados utilizados na etapa de acabamento, como as louças ou metais, que são empregados como recebidos e não fazem parte de outro processo, como no caso das matérias primas. Já estes produtos geralmente estão definidos desde a etapa do projeto, pelo que é suficiente o nome do produto e a marca para a sua identificação.

As vezes, quando estas características não são definidas na etapa do projeto, é importante acompanhar a requisição com especificações de desempenho e com maior quantidade de parâmetros (ex. preço do orçamento, etc.) que sirvam de guia ao comprador para fazer uma escolha apropriada do produto.

(ii) Materiais feitos sob pedido (customized): nestes casos, geralmente, a requisição deve ser feita com bastante antecipação e não basta o nome do recurso para sua identificação. Deve-se prover a maior quantidade de informação para conseguir obter o produto desejado. Projetos para produção, detalhes de projeto e especificações são importantes para a definição do produto.

Nestes casos, precisa-se de um maior contato inicial entre o fornecedor e o pessoal da obra que no caso anterior, para se conseguir esclarecer dúvidas. Além disso, para alguns produtos o fornecedor precisa fazer medições in-situ. Por este motivo, 
muitas empresas construtoras permitem que estes tipos de materiais sejam cotados diretamente pela obra.

- Quantidade: indica a quantidade do produto que se está requisitando. Esta informação provém da etapa anterior, do momento em que se identifica a necessidade do material. Normalmente, é calculada a partir da quantificação ou orçamento, cronograma de materiais e inventário.

Os materiais utilizados na etapa da obra bruta, como as matérias primas e componentes, são usualmente mais difíceis de quantificar. Pela dificuldade de os controlar, são materiais sujeitos a maiores perdas. Para este tipo de materiais é difícil se calcular a quantidade total exata necessária no início do serviço. Nas empresas estudadas, por exemplo, fazia-se a compra destes produtos com base na quantidade do orçamento e, quando faltava material, fazia-se um novo pedido.

Já os materiais utilizados na etapa de acabamento não apresentam este problema e são mais fácies de quantificar, desde o orçamento. A maioria deles são comprados em uma única operação.

- Local de entrega: além de indicar o endereço da obra é melhor prover o fornecedor com antecipação de toda a informação necessária sobre o local preciso de entrega, como por exemplo, deve-se estabelecer desde o início se é necessário que o material seja colocado em um lugar específico no canteiro, etc. A obra deve estar preparada para a recepção do material na data indicada.

- Condições de embalagem e transporte: são informações cada vez mais essenciais a uma boa organização da produção, devendo os fornecedores estarem a par das exigências "negociadas" feitas pela empresa construtora.

- Data de entrega: indica a data quando se necessita que o produto seja entregue na obra. Nos casos de matérias primas e componentes, onde existem várias entregas, 
geralmente a compra se faz através do setor de suprimentos, mas para as entregas a obra contata diretamente o fornecedor e combina com ele a data e a quantidade das entregas.

É recomendável que para os materiais com entregas múltiplas a obra elabore um cronograma de entregas para que o fornecedor possa se programar com antecipação, entregando os produtos sem contratempos.

Por ultimo, é recomendável que a requisição seja aprovada pelo coordenador da obra antes de ser enviada ao setor de suprimentos. Isso acontecia em todos os casos estudados.

A Figura 20 apresenta o processo da elaboração da requisição mostrando os dados de entrada, de saída, as informações adicionais requeridas para completar o processo e a pessoa responsável pela sua execução. Já a Tabela 16 apresenta os principais elementos desta etapa.

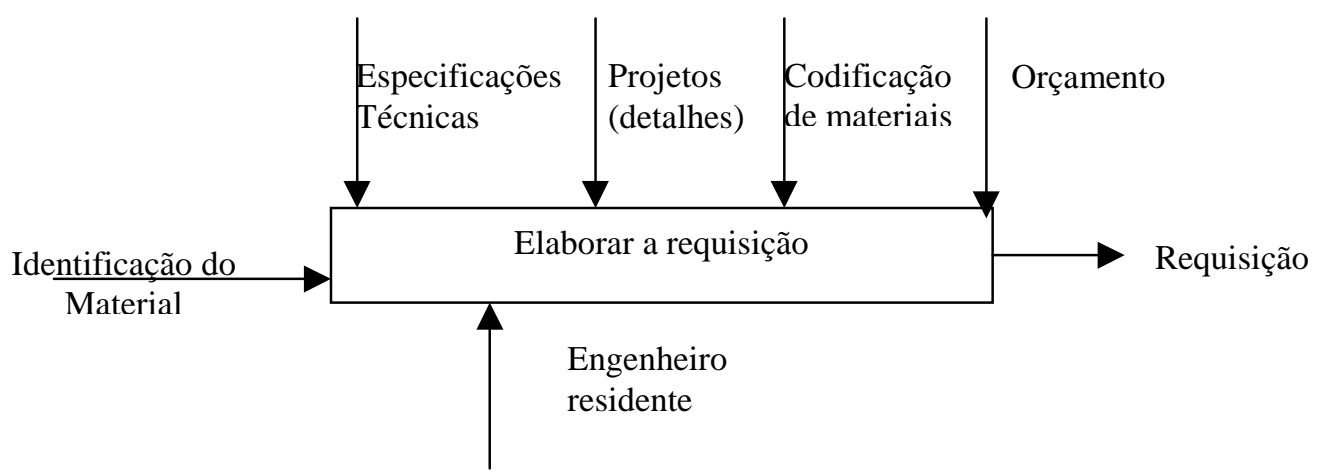

Figura 20.- Elaboração da requisição 
Tabela 16.- Elaboração da requisição

\begin{tabular}{lll}
\hline Informação de Entrada & $\bullet$ & identificação do material \\
\hline Agente ou mecanismo processador & $\bullet$ & engenheiro Residente \\
\hline & $\bullet$ & especificações técnicas; \\
Informações ou documentos & $\bullet$ & projetos; \\
adicionais & $\bullet$ & codificação dos materiais; \\
& $\bullet$ & orçamento. \\
\hline & $\bullet$ & requisição: \\
& $>$ identificação do material (nome ou descrição do \\
Informações de Saída & $>$ material ou codificação existente); \\
& $>>$ local de entrega; \\
& & $>$ condições de embalagem e transporte; \\
\hline Receptor da informação & $\bullet$ coordenador da obra \\
\hline Meio de comunicação & $\bullet$ rede; \\
\hline
\end{tabular}

\subsubsection{Teste de consistência e aprovação da requisição}

O objetivo desta etapa é fazer com que um funcionário de hierarquia superior ao engenheiro da obra, por exemplo o coordenador, revise a consistência da requisição de uma dada obra frente às requisições ou compras a se realizar para outras obras.

A idéia neste caso é que o coordenador, tendo mais experiência que o engenheiro da obra e encontrando-se em uma posição hierárquica superior, com aceso a informações de outras obras, possa identificar a existência de algum motivo pelo qual a requisição não proceda ou seja feita em outro momento.

Além de oferecer suporte às obras devido à sua experiência, o coordenador atua como um vínculo entre elas e as decisões tomadas no nível estratégico. Por exemplo, ele pode sugerir atrasar ou adiantar uma requisição em função de pedidos do mesmo material de outras obras para conseguir fazer uma compra maior com menor preço. Nas empresas 
estudadas verificou-se a existência desta etapa e, em todas elas, o coordenador da obra era o encarregado pela aprovação da requisição.

Nos casos estudados está aprovação fazia-se diretamente no computador, liberando assim a requisição para que o setor de suprimentos pudesse efetuar a compra.

Na Figura 21 e Tabela 17 apresentam-se os principais elementos deste processo.

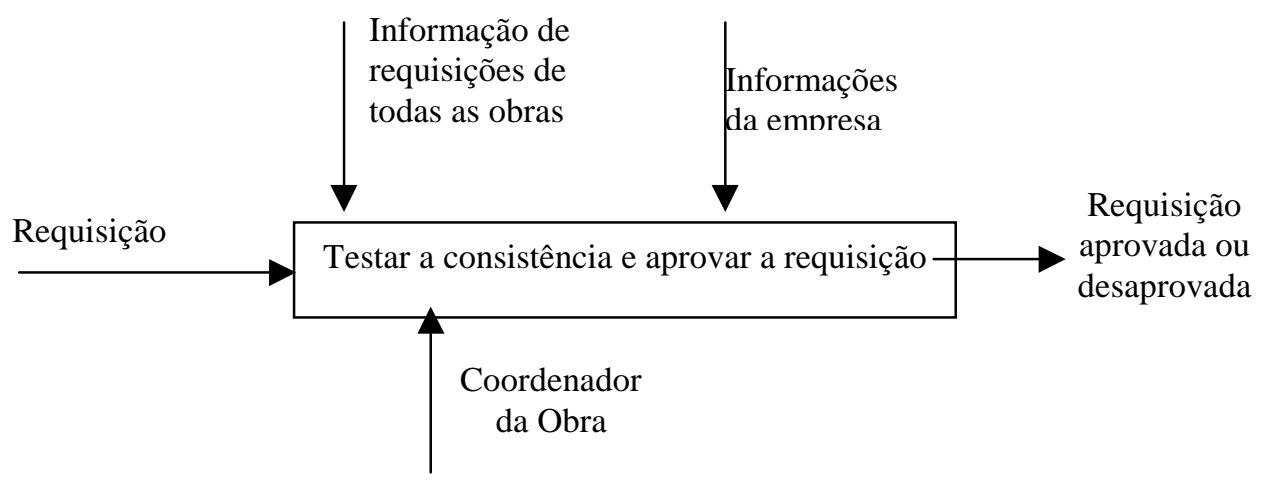

Figura 21.- Testar a consistência e aprovar a requisição

Tabela 17.- Teste da consistência e aprovação da requisição

\begin{tabular}{lll}
\hline Informação de Entrada & $\bullet$ & requisição \\
\hline Agente ou mecanismo processador & $\bullet$ & coordenador de obras \\
\hline Informações ou documentos & $\bullet$ & informações de requisições de todas as obras; \\
adicionais & $\bullet$ & informações da empresa. \\
\hline Informação de Saída & $\bullet$ & requisição aprovada; \\
\hline Receptores da informação & $\bullet$ & requisição desaprovada. \\
\hline Meio de comunicação & $\bullet$ & setor de suprimentos; \\
& $\bullet$ & rede; \\
\hline
\end{tabular}

\subsubsection{Formulação da solicitação da cotação}

Esta etapa inicia-se quando o setor de suprimentos ou a pessoa ou área encarregada pelo estabelecimento do contato com o fornecedor recebe a requisição da obra aprovada pelo coordenador. Nos estudos de caso apresentados, ao receber a requisição o gerente de 
suprimentos conferia se os dados estavam completos e a repassava para seus compradores. No caso da existência de alguma não-conformidade, devolvia a requisição para a obra indicando os erros ou pedindo esclarecimentos sobre a informação passada. Notar que aqui a verificação de consistência é muito mais formal do que sistêmica, o que é feita pelo coordenador, na etapa anterior.

Com a requisição em mãos, o passo seguinte é o de preparar a solicitação de cotação e escolher os fornecedores aos quais solicitá-las. Todas as empresas construtoras estudadas escolhiam seus fornecedores com base no seu cadastro de fornecedores, embora nem todas elas tivessem uma avaliação formalizada dos mesmos.

O cadastro de fornecedores é uma informação muito importante que auxilia as empresas construtoras na compra de produtos. Deve conter telefones e endereços de contato dos fornecedores da empresa. Adicionalmente, deve ser constantemente atualizada segundo as avaliações feitas em obra. É recomendável que a avaliação apareça no cadastro para que sirva de guia para o comprador.

As empresas construtoras estudadas, por exemplo, tinham estes cadastros registrados em bases de dados computarizadas o que facilitava a procura de fornecedores em função do produto.

É importante também que o comprador agrupe os pedidos de materiais iguais de outras obras para poder assim realizar uma compra maior e obter melhores preços. No entanto, como cada obra deve gerenciar suas próprias contas, deve-se solicitar que o fornecedor separe as cotações por obras. Para facilitar este procedimento a empresa deve marcar uma data mensal para que as obras enviem as requisições ao setor de suprimentos.

Já para elaborar a solicitação da cotação, muitas empresas têm procedimentos para a compra de produtos, especialmente as que possuem ou estão em processo de 
implantação de sistema de gestão de qualidade. Estes procedimentos servem de guia para a compra de certos produtos, indicam as especificações e normas a levar em conta como referência e outras informações que auxiliem na compra.

Os principais dados resultado desta etapa são praticamente os mesmos que aparecem na requisição, quais sejam:

- nome do material: sendo que a solicitação da cotação se envia a um fornecedor específico, podendo se apresentar três situações:

(i) materiais que já estão definidos com nome e marca desde a requisição: este caso é o mais simples e o comprador escolhe os fornecedores que vendem estes produtos;

(ii) materiais onde na requisição não está definido exatamente o nome ou a marca de um produto (somente existem as especificações técnicas e de desempenho): nestes casos, geralmente o comprador escolhe um produto em função das informações enviadas para depois decidir os fornecedores aos quais vai solicitar a cotação. Aqui pode ser de muita ajuda para o comprador a existência de documentos da empresa que relacionem especificações técnicas com lista de produtos que cumpram estas especificações;

(iii)produtos fabricados sob pedido: neste caso, o comprador deve anexar os documentos necessários (plantas, projetos para produção, especificações, etc.) para que o fornecedor consiga fazer a cotação do produto especificado. Em muitas empresas, este caso é negociado diretamente na obra ou existe um setor especialmente dedicado a produtos que precisam de mais informações técnicas para serem comprados;

- quantidade;

- local de entrega; 
- condições de embalagem e transporte;

- data de entrega.

A Figura 22 apresenta esta etapa do fluxo indicando as informações de entrada e saída, as informações adicionais necessárias e o agente processador desta etapa.

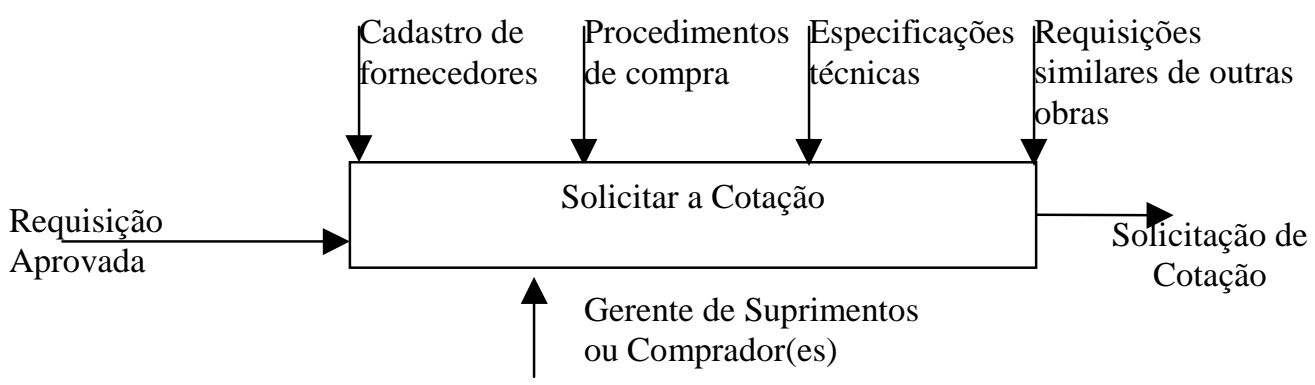

Figura 22.- Solicitação de Cotação

Quanto ao meio de comunicação utilizado para enviar esta solicitação aos fornecedores verificou-se que as três empresas construtoras estudadas utilizavam fax ou telefone. No entanto, atualmente, com a aparição do comercio eletrônico via Internet, está começando a aparecer uma nova opção, não somente de comunicação com o fornecedor, mas também para gerar toda a solicitação de cotação.

Os sítios de comércios eletrônicos que atualmente existem na Internet para o setor da construção estão já disponibilizando cadastros de fornecedores com avaliações feitas pelos clientes que utilizam este sistema. Isso auxilia as empresas construtoras e compradores em geral a ampliar sua base de fornecedores. Além disso, alguns destes sítios também disponibilizam especificações técnicas de materiais que podem ser utilizadas pelas empresas que ainda não têm formalizados suas especificações no momento da compra. Desta forma, estes sítios auxiliam em todo o processo de elaboração da solicitação da cotação. 
Alguns dos sítios que disponibilizam no Brasil este tipo de comercio para o setor são: www.naobra.com.br; www.tapume.com.br; www.superobra.com.br.

A Tabela 18 apresenta os principais elementos que conformam esta etapa:

Tabela 18.- Formulação da solicitação da cotação

\begin{tabular}{lll}
\hline Informação de Entrada & $\bullet$ & requisição aprovada \\
\hline Agente ou mecanismo processador & $\bullet$ & gerente de suprimentos ou comprador (es) \\
\hline \multirow{2}{*}{ Informações ou documentos } & $\bullet$ & cadastro de fornecedores; \\
adicionais & $\bullet$ procedimentos de compra; \\
& $\bullet$ especificações técnicas; \\
& $\bullet$ requisições de outras obras. \\
\hline & $\bullet$ solicitação de cotação: \\
& $>$ nome do material; \\
Informação de Saída & $>$ quantidade; \\
& $>>$ local de entrega; \\
& & $>$ data de entrega. \\
\hline Receptor da informação & $\bullet$ & fornecedores \\
\hline & $\bullet$ & fax; \\
Meio de comunicação & $\bullet$ telefone; \\
& $\bullet \quad$ Internet. \\
\hline
\end{tabular}

\subsubsection{Elaboração da cotação}

Já esta etapa é uma que não é realizada pela empresa construtora mas pela empresa fornecedora. O fornecedor, ao receber a solicitação de cotação, verifica seus estoques e sua capacidade para cumprir com o pedido solicitado nas condições especificadas. Segundo esses dados elabora sua cotação onde especifica o preço de seu produto e as condições a que se compromete cumprir.

As principais informações que deverá ter uma cotação são: o nome do material solicitado; o preço deste material; as condições de pagamento; e as condições de entrega oferece. No caso de o fornecedor vender outros produtos similares pode também colocar os preços das diferentes alternativas que ele oferece. 
Como foi comentado na etapa anterior, apesar de atualmente a comunicação entre o fornecedor e a empresa construtora se dar principalmente através de telefone ou fax, existe a expectativa de que em um futuro próximo as tecnologias da informação, como a Internet por exemplo, consigam agilizar e integrar as informações entre estes dois agentes como está acontecendo em outras indústrias.

Essa etapa do processo não foi pesquisada neste trabalho. A Figura 23 e a Tabela 19 apresentam os principais elementos deste processo.

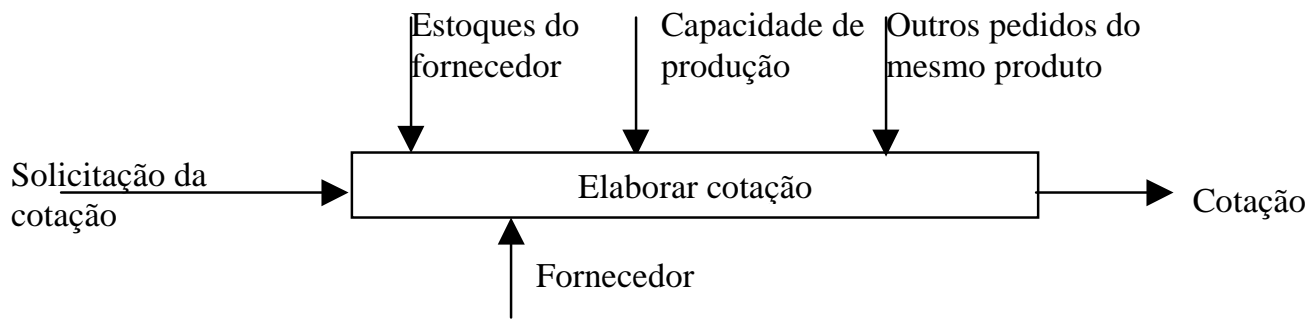

Figura 23.- Elaborar cotação

Tabela 19.- Elaboração da cotação

\begin{tabular}{lll}
\hline Informação de Entrada & $\bullet$ & solicitação da cotação \\
\hline Agente ou mecanismo processador & $\bullet$ & fornecedor \\
\hline Informações ou documentos & $\bullet$ & estoques do fornecedor; \\
adicionais & $\bullet$ & capacidade de produção; \\
& $\bullet$ & outros pedidos do mesmo produto \\
\hline & $\bullet$ & cotação: \\
& $>$ nome do material; \\
Informação de Saída & $>$ preço; \\
& $>$ condições de entrega; \\
& $>$ condições de pagamento; \\
\hline Receptores da informação & $\bullet$ setor de suprimentos \\
\hline & $\bullet$ fax; \\
Meio de comunicação & $\bullet$ telefone; \\
& $\bullet$ & Internet. \\
\hline
\end{tabular}




\subsubsection{Escolha do fornecedor}

Esta etapa começa quando a empresa construtora recebe as cotações solicitadas aos fornecedores. Nas empresas construtoras estudadas, a seleção do fornecedor ficava sob a responsabilidade do gerente de suprimentos ou do diretor técnico, segundo o montante da cotação.

Na empresa A, por exemplo, a qual possuía uma estrutura organizacional bastante centralizada, a maior parte das compras era decidida pelo diretor técnico. Esta situação as vezes ocasionava morosidade no processo, já que existia uma saturação de responsabilidades nas hierarquias superiores. Já a empresa $\mathrm{C}$, que possuía uma estrutura organizacional com maior grau de descentralização, permitia ao gerente de suprimentos decidir sobre as compras realizadas pelo seu setor e deixava a seu critério as consultas ao diretor técnico. Neste caso, o modelo dava flexibilidade ao processo e permitia tomada de decisões mais rápidas.

Levando em consideração os fatores apresentados anteriormente pode-se afirmar que nos casos das empresas com área de suprimentos centralizada é recomendável que o chefe desta área tenha poder de decisão pelas compras efetuadas pelo seu setor. Mas para que funcione este modelo, o chefe de suprimentos deve possuir algumas características, quais sejam: ser uma pessoa de confiança da empresa, possuir experiência no ramo, conhecer as condições de pagamento com as quais costuma trabalhar a empresa e ter o bom senso para saber em quais ocasiões deve consultar a diretoria para decidir sobre uma compra.

Geralmente, nos casos de compras grandes, é normal se precisar da opinião do diretor técnico para a tomada de decisões, sendo muitas vezes ele quem decide dividir a compra entre dois ou mais fornecedores ou negociar diretamente com estes para obter um 
melhor preço ou melhores condições. Geralmente, as negociações para conseguir melhores preços ou condições de pagamento ou entrega se dão entre as hierarquias superiores das empresas interessadas.

Embora possam-se apresentar inumeráveis situações, para efetuar uma acertada tomada de decisão na eleição da cotação (fornecedor), é recomendável que cada empresa construtora estabeleça suas regras para evitar saturações nas hierarquias superiores. Existem produtos com os quais inevitavelmente o diretor deverá estar envolvido, para os quais deve-se estudar a conveniência de se estabelecer parcerias com fornecedores, e depois se estabelecer rotinas para a compra. Isso acontecia com alguns materiais na empresa C.

Os cronogramas de materiais semestrais, como os estabelecidos pela empresa C, são também de muita utilidade nesta etapa, já que permitem ao setor de compras e à diretoria agrupar pedidos grandes e negociar com os fornecedores uma ou duas vezes no ano. De fato, conhecendo com antecipação as compras semestrais da empresa, pode-se programar os pedidos grandes e restringir-se as negociações a uma ou duas vezes ao ano, fazendo com que a diretoria fique principalmente envolvida nestes períodos e deixando as compras menores sob a responsabilidade do gerente da área de suprimentos ou compradores, segundo o montante da compra.

Em geral, os principais fatores a se levar em conta para a tomada de decisão são: o preço do material; as condições de pagamento impostas pelo fornecedor; as condições da entrega; e a confiabilidade do fornecedor (via cadastro de fornecedores).

Atualmente, as empresas construtoras estão começando a perceber que a confiabilidade do fornecedor é um dos principais fatores a se considerar para a seleção da cotação. 
Como foi explicado no capitulo 2, o preço do material não deve ser analisado isoladamente mas como parte de um conjunto de custos.

Também o estabelecimento de reais parcerias com fornecedores, com alinhamento estratégico de empresas e mutua confiança, é uma tendência que poderá agilizar esta etapa com benefícios para todos, eliminando atividades que não agregam valor.

Na Figura 24 e Tabela 20 apresenta-se este processo e seus principais elementos.

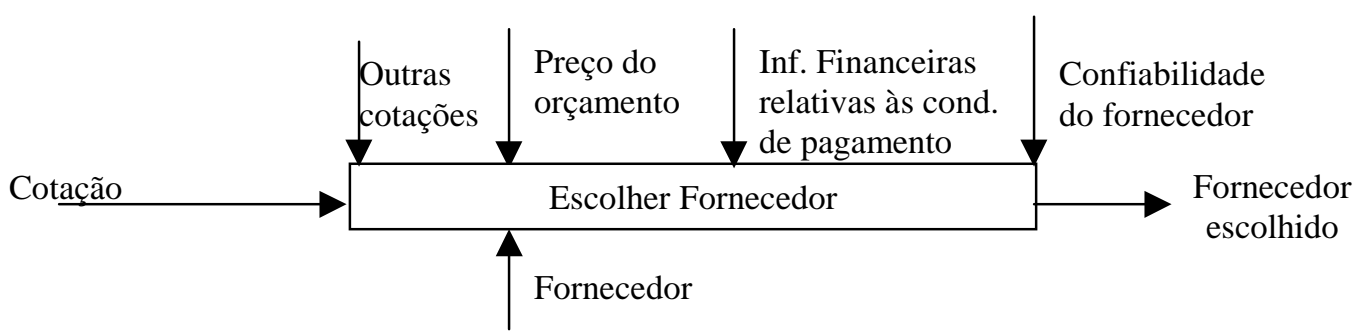

Figura 24.- Escolher fornecedor

Tabela 20.- Escolha do fornecedor

\begin{tabular}{lll}
\hline Informação de Entrada & $\bullet$ & cotação \\
\hline Agente ou mecanismo processador & $\bullet$ & $\begin{array}{l}\text { diretor técnico ou gerente de suprimentos ou } \\
\text { comprador }\end{array}$ \\
\hline & $\bullet$ & outras cotações; \\
& $\bullet$ & preço colocado no orçamento; \\
& $\bullet$ & informações financeiras que se relacionem às \\
& & condiçôes de pagamento colocadas pelo fornecedor; \\
Informações ou documentos & $\bullet$ & informações da obra que se relacionem às \\
adicionais & condições de entrega colocadas pelo fornecedor; \\
& $\bullet$ & confiabilidade do fornecedor (cadastro de \\
& fornecedores). \\
\hline Informação de Saída & $\bullet$ & nome do fornecedor(es) do(s) qual (quais) se \\
& & comprará o material \\
\hline Receptor da informação & $\bullet$ & setor de suprimentos \\
\hline Meio de comunicação & $\bullet$ & documento escrito; \\
\hline
\end{tabular}




\subsubsection{Compra e formulação do pedido de compra}

Já esta etapa se inicia quando a empresa construtora escolhe o(s) fornecedor(es) que irá(ão) fornecer o material requisitado. Este processo se divide em duas etapas principais:

- confirmação da compra com o fornecedor: consiste na confirmação dos dados da compra (material, quantidade), entrega, pagamento e informações adicionais (dados que devem aparecer na nota fiscal, penalidades em caso de não cumprimento, etc.) com o fornecedor através de um documento chamado "pedido de compra". Esta confirmação normalmente é enviada por fax ao fornecedor. Se a compra foi estabelecida através da Internet pode ser enviada através deste meio de comunicação. É importante também se anexar e confirmar os documentos (especificações, projetos, etc.) que tomam parte da compra.

- Comunicação da compra à obra e ao contas a pagar: consiste no envio do pedido de compra à obra e ao setor de contas a pagar. Nas empresas construtoras B e C, por exemplo, este documento ficava na rede e era indispensável no momento da recepção de materiais e para efetuar o pagamento.

As principais informações que deverão aparecer no pedido de compra são: (i) identificação do fornecedor: nome, telefone, endereço; (ii) identificação do produto comprado: nome, quantidade; (iii) condições de pagamento; (iv) local de entrega: nome, endereço e telefone da obra; (v) condições de embalagem e transporte; (vi) data da entrega; (vii) informações adicionais ou complementares que foram estabelecidas no momento da compra. Por exemplo, aqui pode-se colocar os documentos (especificações, projetos, etc.) que tomaram parte do processo de compra (ver Tabela 21 e Figura 25). 


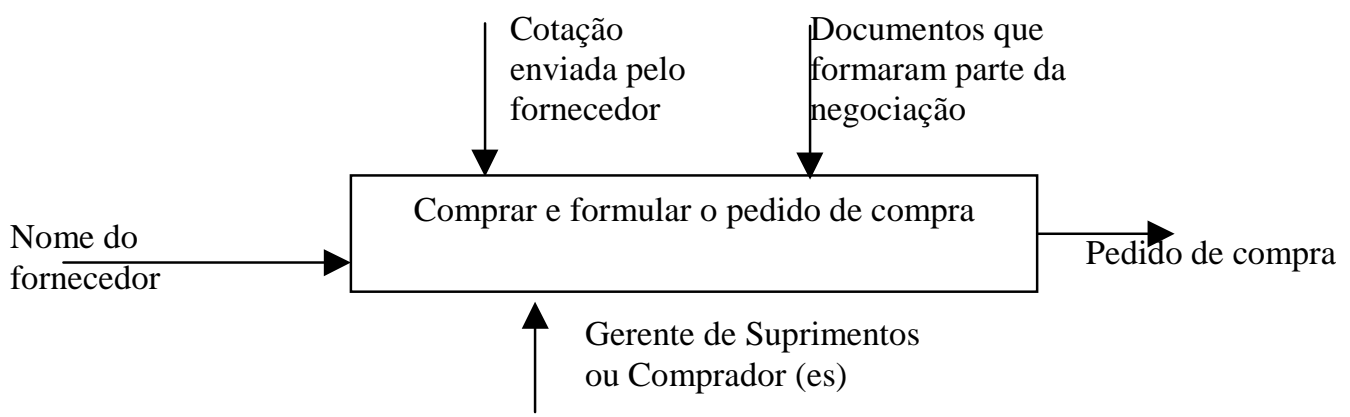

Figura 25.- Comprar e formular pedido de compra

Tabela 21.- Compra e formulação do pedido de compra

\begin{tabular}{|c|c|}
\hline Informação de Entrada & $\begin{array}{l}\text { - nome do fornecedor (es) do(s) qual (quais) se } \\
\text { comprará o material }\end{array}$ \\
\hline Agente ou mecanismo processador & - gerente de suprimentos ou comprador \\
\hline $\begin{array}{l}\text { Informações ou documentos } \\
\text { adicionais }\end{array}$ & $\begin{array}{l}\text { - } \quad \text { cotação enviada pelo fornecedor; } \\
\text { - documentos que tomaram parte da negociação. }\end{array}$ \\
\hline Informação de Saída & $\begin{array}{l}\text { - pedido de compra: } \\
\quad \text { identificação do fornecedor: nome, telefone, } \\
\text { endereço; } \\
>\text { identificação do produto comprado: nome, } \\
\text { quantidade; } \\
>\text { condições de pagamento; } \\
>\text { local de entrega: nome, endereço e telefone da } \\
\text { obra; } \\
>\text { condições de embalagem e transporte; } \\
>\text { data da entrega; } \\
>\text { informações adicionais ou complementares que } \\
\text { foram estabelecidas no momento da compra } \\
\text { (especificações, projetos, etc.). }\end{array}$ \\
\hline Receptores da informação & $\begin{array}{l}\text { - contas a pagar; } \\
\text { - obra; } \\
\text { - fornecedor. }\end{array}$ \\
\hline Meio de comunicação & $\begin{array}{l}\text { - } \\
\text { - } \\
\text { rede }\end{array}$ \\
\hline
\end{tabular}




\subsubsection{Recepção do produto}

A chegada do material à obra é uma etapa muito importante. Deve-se programar com antecipação os locais onde serão recebidos e armazenados os materiais. Nesse sentido as condições de embalagem e transporte são essenciais (tipo de embalagem, pallet, tipo de caminhão, equipamento de descarga do caminhão, etc.). Além disso, deve-se ter disponíveis os documentos para o recebimento dos materiais, quais sejam: pedido de compra, especificações técnicas, procedimentos de recebimento e de inspeção, etc.

Para materiais cuja data de entrega foi especificada no momento da compra, esta etapa inicia-se quando o material chega na obra. Já no caso dos materiais para os quais a entrega depende de decisão da obra em função de suas necessidades, como por exemplo as matérias primas, esta etapa inicia-se no momento em que o interessado se comunica com o fornecedor pedindo-lhe a entrega do produto em uma data específica. Como já foi colocado, para evitar atrasos na entrega, é melhor entregar ao fornecedor um cronograma com previsões de entregas de materiais.

As informações que serão o resultado desta etapa podem ser as seguintes:

- liberação do pagamento: se existir conformidade na recepção a obra libera o pagamento e comunica o fato ao setor de contas a pagar;

- entrada do material na obra: quando o material é aceito avisa-se as equipes de produção interessadas de sua entrada;

- não-conformidade: se dá quando não existe conformidade na entrega. A identificação de uma não-conformidade é feita através dos procedimentos internos da empresa, do pedido de compra e dos documentos que tomaram parte na compra. A idéia é que o material apresente características compatíveis com os parâmetros de aceitação especificados nos procedimentos e os dados do pedido de compra. Caso o 
contrario, existe a ocorrência de uma não-conformidade. Dependendo da gravidade da mesma, em alguns casos a própria obra pode acertar a solução diretamente com o fornecedor, sem comunicar ao setor de suprimentos; já em outros comunica-se os problemas a suprimentos;

- avaliação do fornecedor: refere-se à avaliação que a obra faz do fornecedor com respeito ao material entregue e ao serviço prestado. Os principais parâmetros que devem ser avaliados são: cumprimentos dos prazos, conformidade do produto às especificações, qualidade do atendimento, inexistência de erros na fatura ou nota fiscal, entre outros. Esta informação deve ser comunicada à área de suprimentos ou compras.

A seguir apresenta-se com mais detalhe o que acontece no momento da recepção de materiais na obra.

No momento da chegada do material à obra, a principal preocupação da pessoa encarregada pelo seu recebimento deve ser a de conferir que o mesmo coincida em qualidade e quantidade com o material requisitado. Os principais documentos que se devem utilizar nesta etapa são:

(i) procedimentos de recebimento e inspeção de materiais: estes servem para efetuar o controle da qualidade no recebimento. Dependendo do material e do tipo dos ensaios e verificações a serem feitos, o controle pode ser delegado a um laboratório especializado, contratado especificamente para tal fim. Já para os materiais a serem controlados na obra podem ser utilizadas três formas básicas (Souza et al., 1995):

- inspeção a 100\%: como esta prática consiste em verificar todas as unidades do produto que compõem o lote entregue, sua utilização é viável somente no caso 
de materiais especiais de grande responsabilidade, ou quando a quantidade entregue for pequena, viabilizando seu uso.

- Inspeção ao acaso: consiste em se tomar uma amostra ao acaso, sem fundamentação no cálculo de probabilidades, mas baseada em procedimento interno da empresa que fixa as regras para tal amostragem. Verifica-se a qualidade das unidades que compõem a amostra e, em função dos resultados obtidos e do que é previsto em procedimento interno, decide-se aceitar ou rejeitar o lote inteiro. Sendo que este método é muito subjetivo, pode-se utilizar para materiais de pequena responsabilidade ou com fornecedores cujo histórico permita atenuar o controle no recebimento.

- Inspeção por amostragem estatística: consiste em se tomar do lote uma amostra fundamentada em cálculo de probabilidades. Em função do número de unidades defeituosas encontradas na amostra, decide-se aceitar ou rejeitar o lote inteiro.

Quando há norma brasileira para controle da qualidade de um material, normalmente é essa a forma adotada.

Nas empresas estudadas a inspeção era geralmente feita ao acaso, a justificativa era que trabalhavam com fornecedores de sua confiança. $\mathrm{O}$ recebimento dos produtos normalmente ficava sob a responsabilidade do almoxarife, e somente em casos de materiais especiais se requeria a presença do engenheiro residente.

Na empresa C, por exemplo, o engenheiro responsável pela obra somente recebia produtos como pias de mármore ou portas de madeira, os demais sendo recebidos pelo almoxarife.

As três empresas estudadas tinham formalizados em certo grau seus procedimentos de recebimento de materiais, sendo a empresa $\mathrm{C}$ a que apresentava maior grau de formalização (certificada ISO 9002). Em seguida estava a empresa B que se 
encontrava em processo de elaboração de seus procedimentos e por último estava a empresa A que somente possuía alguns procedimentos formalizados.

(ii) Pedido de compra: como já foi indicado este documento deve conter todas as informações que foram repassadas ao fornecedor no momento da compra: nome do produto, quantidade, especificações, local de entrega, condições de embalagem, data de entrega, etc. No momento da recepção do material, deve-se conferir que o material esteja em conformidade com o acordado.

(iii) Formulário de relatório de não-conformidade: serve para facilitar o repasse e o arquivamento de informações quando existir uma não-conformidade na entrega. No caso da existência de uma discordância na entrega, dependendo da gravidade da mesma, pode-se optar por solucionar o problema diretamente com o fornecedor ou não aceitar a entrega. Nas empresas estudadas, por exemplo, na maior parte dos casos tratava-se de solucionar o problema diretamente com o fornecedor, e somente quando existia um erro grave de qualidade ou o fornecedor era reincidente optava-se por comunicar o problema ao setor de suprimentos.

Tal ocorrência deve ser registrada de forma detalhada em um documento específico, bem como a proposta de solução de correção para a mesma. Tal proposta deve ser feita pelo engenheiro da obra ou pela pessoa responsável pela recepção onde foi identificada a não-conformidade e submetida aos comentários do fornecedor, se necessário.

Os principais dados que devem aparecer em um formulário de relatório de nãoconformidade são: identificação da obra; identificação do fornecedor; identificação do material; data; descrição detalhada da não-conformidade; solução adotada; comentários do fornecedor (se houver); assinaturas do fornecedor ou responsável 
pela entrega e do engenheiro da obra ou responsável pelo recebimento; nova inspeção após correção; nova condição de aprovado ou rejeitado.

É importante se ter indicadores da ocorrência de não-conformidades para verificar se o problema é um fato isolado ou já aconteceu em outras obras, e comunicar ao coordenador da obra ou o diretor técnico, caso o fato ocorra de modo repetitivo.

(iv) Nota fiscal: a quantidade indicada deve coincidir com a quantidade entregue na obra e o preço com o estabelecido no momento da compra. Se a entregue for aceita deve-se aprovar a nota fiscal, liberar o pagamento e enviar a nota ao contas a pagar.

Por último, em cada entregue deve-se proceder a uma avaliação ao fornecedor. Cada empresa deve possuir um cadastro de fornecedores avaliados com base no preço, pontualidade na entrega, conformidade do produto às especificações e outros itens de análise que a empresa julgar pertinentes para cada produto em questão. A única forma de manter atualizado este cadastro é através da avaliação formal feita pelas obras.

Nas empresas estudadas, somente na empresa $\mathrm{C}$ verificou-se que existia um formulário para avaliar os fornecedores. Nas outras duas, esta avaliação era feita informalmente e verbalmente sem levar registro. Na Figura 26 e Tabela 22 apresentam-se os principais elementos desta etapa:

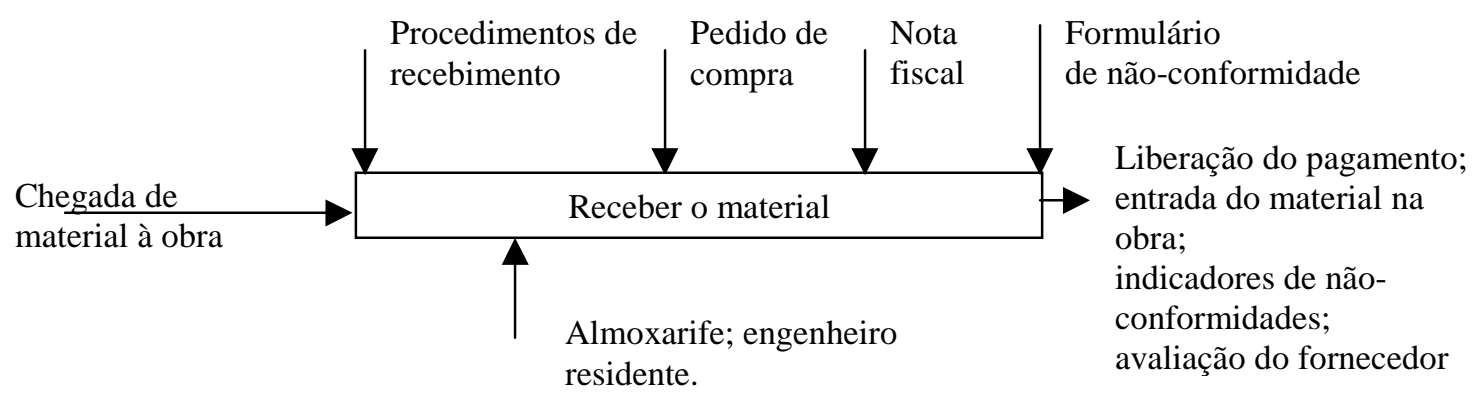

Figura 26.- Receber o material 
Tabela 22.- Recepção do material

\begin{tabular}{|c|c|}
\hline Informação de Entrada & - chegada do material à obra \\
\hline Agente ou mecanismo processador & $\begin{array}{l}\text { - } \quad \text { almoxarife; } \\
\text { - eng. residente. }\end{array}$ \\
\hline $\begin{array}{l}\text { Informações ou documentos } \\
\text { adicionais }\end{array}$ & $\begin{array}{l}\text { - } \text { procedimentos de recebimento; } \\
\text { - } \text { pedido de compra; } \\
\text { - nota fiscal; } \\
\text { - formulário de não-conformidade (se necessário). }\end{array}$ \\
\hline Informação de Saída & $\begin{array}{l}\text { - } \quad \text { liberação do pagamento; } \\
\text { - } \quad \text { entrada do material na obra; } \\
\text { - } \quad \text { indicadores de não-conformidade; } \\
\text { - } \quad \text { avaliação do fornecedor. }\end{array}$ \\
\hline Receptores da informação & $\begin{array}{l}\text { - } \\
\text { - } \text { equipe de produção; } \\
\text { - } \quad \text { setor de suprimentos; } \\
\text { - } \quad \text { coordenador ou diretor técnico (caso de não- } \\
\text { conformidade). }\end{array}$ \\
\hline Meio de comunicação & $\begin{array}{ll}\text { - } & \text { rede; } \\
\text { - } & \text { mala direta; } \\
\text { - } & \text { verbal. }\end{array}$ \\
\hline
\end{tabular}

\subsubsection{Pagamento}

Já a última etapa do fluxo se dá quando o fornecedor recebe o pagamento pelo material. Com a confirmação da aceitação do material por parte da obra, o setor de contas a pagar pode liberar o pagamento ao fornecedor, em concordância com o acordado nas condições de pagamento (ver Figura 27 e Figura 23).

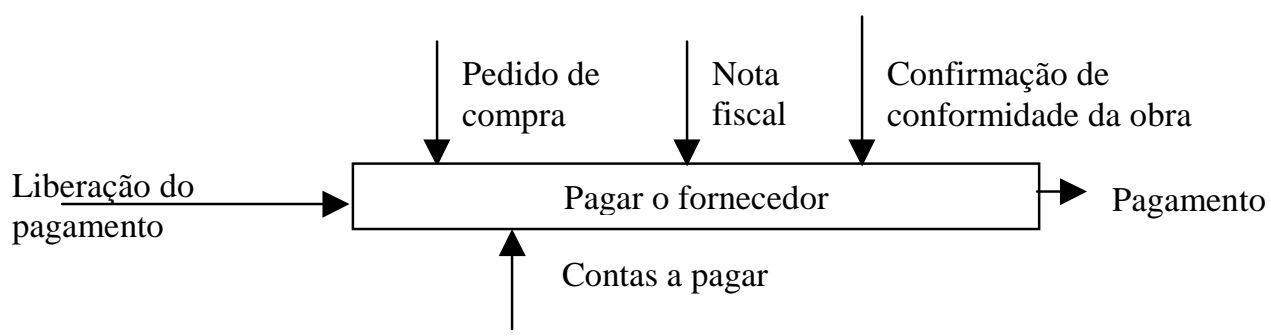

Figura 27.- Pagar ao fornecedor 
Tabela 23.- Pagamento

\begin{tabular}{lll}
\hline Informação de Entrada & $\bullet$ & liberação do pagamento \\
\hline Agente ou mecanismo processador & $\bullet$ & contas a pagar \\
\hline Informações ou documentos & $\bullet$ & pedido de compra; \\
adicionais & $\bullet$ & nota fiscal; \\
& $\bullet$ & confirmação de conformidade por parte da obra \\
\hline Informação de Saída & $\bullet$ & pagamento \\
\hline Receptor da informação & $\bullet$ & fornecedor \\
\hline Meio de comunicação & $\bullet$ & escrito \\
\hline
\end{tabular}

Para resumir esta análise do processamento de informações, nas Figura 28 e Figura 29 apresentam-se no DFD o resumo destas etapas e as informações que por elas circulam. A diferencia dos outros DFD anteriormente apresentados nesta dissertação, é que se está fazendo uso de cores para diferenciar entre os locais que passa a informação e se esta informação é repassada através da rede da empresa ou outros meios.

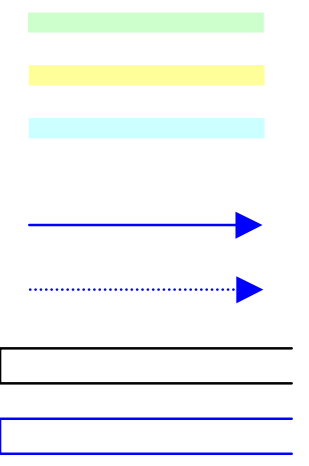

Processo realizado no canteiro de obras

Processo realizado no escritório central

Processo realizado pelo fornecedor

Informacão transmitida através da rede da empresa construtora e integrada ao sistema

Informação transmitida entre empresa construtora e fornecedores utilizando tecnologias de informacão (telefone: fax: Internet. EDI).

Banco de dados aue não pertence à rede

Banco de dados em rede 


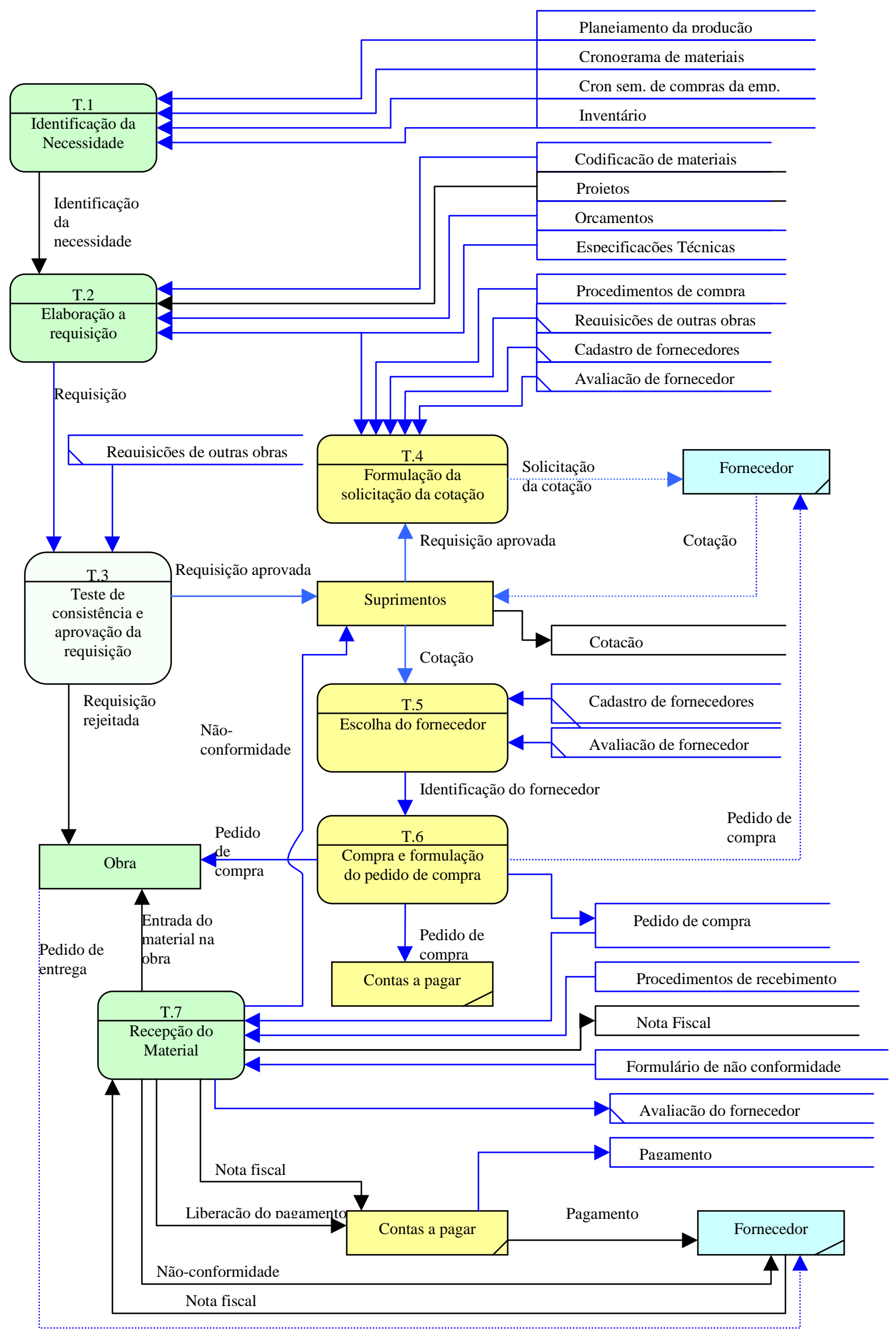

Figura 28.- DFD modelo segundo os casos estudados 


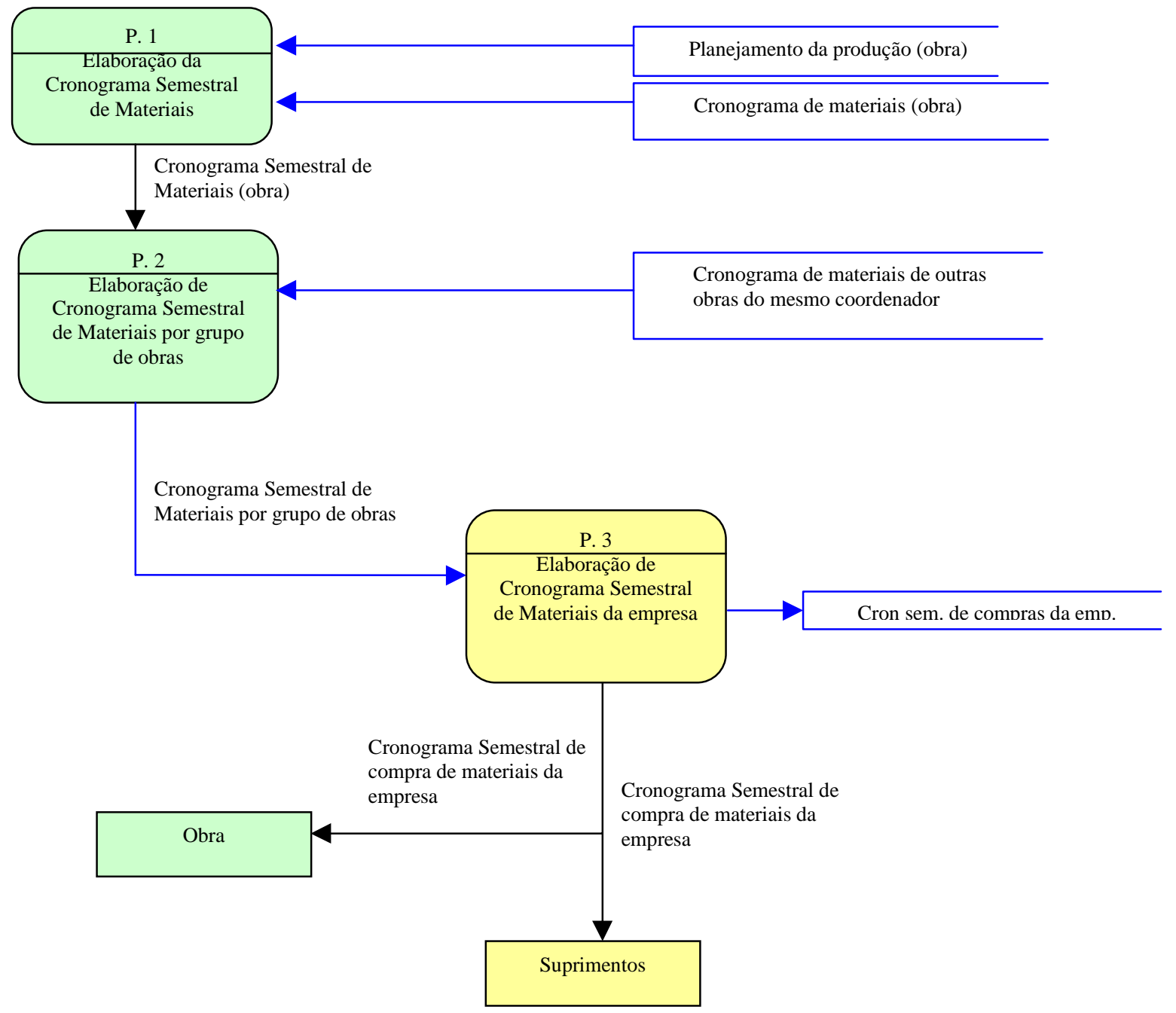

Figura 29.- DFD modelo para a elaboração do cronograma semestral de compras da empresa

Por sua vez, a Tabela 24 apresenta o dicionário de dados para os fluxos do modelo proposto. 
Tabela 24.- Dicionário de Dados para os fluxos do modelo proposto

\begin{tabular}{|c|c|}
\hline Informação & Dicionário de Dados \\
\hline $\begin{array}{l}\text { Identificação do material } \\
\text { necessário }\end{array}$ & $\begin{array}{l}\text { Refere-se à identificação do material necessário à obra; contém os } \\
\text { seguintes dados: nome e quantidade. }\end{array}$ \\
\hline Requisição & $\begin{array}{l}\text { Refere-se às informações que servirão para efetuar a compra: } \\
\text { identificação do material, quantidade, local de entrega, condições } \\
\text { de embalagem e transporte; data de entrega. }\end{array}$ \\
\hline Requisição aprovada & Refere-se à requisição anterior aprovada pelo coordenador. \\
\hline Solicitação da cotação & $\begin{array}{l}\text { Refere-se à informação que será enviada ao fornecedor para } \\
\text { solicitar a cotação. Contem os seguintes dados: nome do material, } \\
\text { quantidade, local de entrega, condições de embalagem e transporte; } \\
\text { data de entrega. }\end{array}$ \\
\hline Cotação & $\begin{array}{l}\text { Refere-se ao documento enviado pelo fornecedor indicando o } \\
\text { nome do material, quantidade, preço unitário, preço total e } \\
\text { condições de pagamento e entrega. }\end{array}$ \\
\hline Escolha do fornecedor & $\begin{array}{l}\text { Refere-se à informação que indica o(s) nome do(s) fornecedor(es) } \\
\text { do(s) qual (quais) se comprará o produto. }\end{array}$ \\
\hline Pedido de compra & $\begin{array}{l}\text { Refere-se ao documento da empresa que é feito no momento da } \\
\text { compra, onde se especifica: dados do fornecedor; nome do } \\
\text { produto; quantidade; custo unitário e total da compra; condições de } \\
\text { pagamento; identificação da obra; local de entrega; data de entrega; } \\
\text { condições de embalagem e transporte; e outras informações que } \\
\text { fazem parte da compra. }\end{array}$ \\
\hline Pedido de entrega & $\begin{array}{l}\text { Refere-se ao pedido que faz a obra ao fornecedor solicitando-lhe a } \\
\text { entrega do material em uma data específica. }\end{array}$ \\
\hline Liberação do pagamento & Refere-se à aprovação por parte da obra de material recebido. \\
\hline $\begin{array}{l}\text { Entrada de material na } \\
\text { obra }\end{array}$ & $\begin{array}{l}\text { Refere-se à notificação às equipes encarregadas da chegada do } \\
\text { material à obra. }\end{array}$ \\
\hline Não-conformidade & $\begin{array}{l}\text { Refere-se à informação que indica uma não-conformidade na } \\
\text { entrega. }\end{array}$ \\
\hline Pagamento & Refere-se ao pagamento da empresa feito ao fornecedor. \\
\hline
\end{tabular}

Em resumo, neste item foram analisados os fluxos de informações relativos à gestão de materiais com base nos casos estudados. A partir desta análise foram identificados os principais problemas que estes fluxos apresentavam, sendo que as causas destes problemas foram vinculadas com a forma dos fluxos de informação ou com as etapas pelas quais eram processadas as informações. 
Para tanto, foram analisadas separadamente tanto a estrutura destes fluxos quanto as etapas onde eram processadas as informações. Assim sendo, resgatou-se as principais virtudes que estes fluxos deveriam apresentar para garantir a eficiência dos mesmos.

Sendo que toda esta análise foi realizada exclusivamente em função dos três casos estudados segundo um ponto de vista tradicional, restaria por discutir a forma segundo a qual este sistema deva ser avaliado em busca de uma melhoria continua e a possibilidade de inovar estes fluxos através de enfoques como o estabelecimento de parcerias entre a construtora e fornecedora, o uso de produtos normalizados e com garantia, o uso de código de barras para a identificação de materiais e o uso intensivo da Internet como meio de comunicação entre a empresa construtora e seus fornecedores. Isso é feito a seguir.

\subsection{Busca da Melhoria Continua e Inovação do Sistema}

Como já foi colocado, neste item pretende-se discutir os parâmetros segundo os quais o sistema de informação deve ser avaliado, procurando-se garantir que ocorra sua melhoria continua. Além disso, discute-se a forma de inovar estes fluxos através de parcerias com os fornecedores, o uso de produtos normalizados e o uso de tecnologias da informação como a Internet e os códigos de barras.

Para conseguir uma melhoria continua do sistema deve-se garantir a existência de formas de avaliação que indiquem se o mesmo está trabalhando segundo o planejado. Portanto, é importante o estabelecimento de controles e de indicadores que auxiliem nesta tarefa. A idéia é a de se conseguir através destes indicadores re-alimentar o sistema para aprimorá-lo.

Nesse sentido, é importante medir a eficiência e a eficácia do sistema de comunicação, lembrando que a eficiência busca que a comunicação se estabeleça com o mínimo de 
recursos enquanto que a eficácia busca que o resultado obtido esteja de acordo com o imaginado pelo transmissor. Em outras palavras, no caso de um sistema de informações que dá subsídios ao fluxo de informações relativas à gestão de materiais, diz-se que o sistema é eficaz quando os materiais chegam às obras quando e como necessários (atendendo aos critérios básicos de qualidade, prazo e custo).

Baseando-se nestes critérios, a eficiência do sistema pode ser medida através de:

- o tempo que leva o material desde a sua requisição até que chegue no canteiro. Neste caso, é importante distinguir entre o tempo que pertence à empresa e o tempo que pertence ao fornecedor, para poder estabelecer as causas dos eventuais problemas existentes.

- A porcentagem relativa (baseada em tempo, número, custo de equipe, etc.) de atividades que não agregam valor, como por exemplo, as de controle e conferências em geral, retrabalhos, contratos ineficazes com fornecedores, solicitações de cotação sem respostas, duplos registros de dados e informações, etc.

- O custo de implementação e de manutenção do sistema.

Já a eficácia do sistema pode ser medida através de:

- o número de ocorrências de não-conformidades em um determinado período;

- o tipo de não-conformidades: deve-se distinguir se as mesmas estão relacionadas a problemas de qualidade, quantidade, atendimento, erros de nota fiscal, etc. Note-se que alguns destes problemas podem estar relacionados com uma escolha inadequada do fornecedor, devido a um funcionamento incorreto do sistema de avaliação de fornecedores.

- O grau de satisfação dos usuários internos: é importante conhecer a opinião dos usuários do sistema a fim de estabelecer se os formatos que estão sendo utilizados 
são suficientemente claros, têm todas as informações necessárias, são fácies de preencher, se as informações de que eles necessitam estão sendo obtidas através da rede, etc.

Para cada um destes indicadores a empresa deve estabelecer parâmetros de referência para conseguir saber se o sistema está trabalhando segundo o esperado ou não. Para tanto, ela deve colocar metas ou objetivos por períodos de tempo e designar pessoa(as) encarregada(s) por esta função. Desta forma, ela poderá atingir patamares superiores de desempenho com o tempo.

Por outro lado, para conseguir uma inovação do sistema, deve-se pensar na aplicação de conceitos que consigam transformar o sistema. Nesse sentido, pensou-se na implementação de parcerias com fornecedores e no uso de produtos normalizados, da Internet e dos códigos de barras como propiciadores desta transformação.

Por um lado, a implementação de parcerias com fornecedores, as quais estão baseadas em uma relação de confiança entre parceiros que faz com que ambos ganhem promovendo uma melhoria continua de qualidade, produtividade e competitividade, pode promover mudanças nos fluxos de informação.

Por exemplo, as parcerias podem diminuir as etapas requeridas em fazer a requisição, fazendo com que a obra possa solicitar os materiais diretamente ao fornecedor sem passar pela central de suprimentos. Neste caso, diminui o tempo do processo além de fazê-lo menos burocrático. Adicionalmente, sendo que as parcerias estão baseadas em uma relação de confiança e de compartimento de informações, pode-se poupar etapas no momento da escolha, avaliação do fornecedor e do controle do material quando este é entregue à obra. 
No entanto, o estabelecimento de parcerias entre empresas não é aplicável nem vai trazer benefícios em todos os casos. Portanto, para conseguir o sucesso desejado deve-se primeiro escolher cuidadosamente os fornecedores mais adequados para tal fim.

Para distinguir os fornecedores com os quais seria interessante estabelecer parcerias, a empresa construtora pode, em um primeiro momento, utilizar a curva $\mathrm{ABC}$ e identificar os produtos com maior incidência no custo das obras. Uma outra diferenciação pode-se fazer com base na classificação discutida no Capítulo 2, matérias primas, produtos terminados produzidos em massa ou produtos feitos sob encomenda. Segundo esta classificação os fornecedores que têm maior potencial para proporcionar e ganhar benefícios através de parcerias seriam tantos os de produtos terminados quanto os de produtos feitos sob encomenda. Somente em casos muito específicos é conveniente fazer parcerias com os produtores de matérias primas, sendo que a tendência das construtoras é a de se converter em uma empresa integradora, caberia aos fornecedores de sistemas fazer parcerias com este tipo de fornecedor. Além disso, sendo a oferta destes produtos no mercado muito elevada, a formação de uma parceria poderia ir em detrimento das vantagens em termos de custos que podem ser adquiridas por causa da competição entre fornecedores.

Outro ponto a se considerar quando se está pensando estabelecer parcerias, é o tamanho das empresas envolvidas. Para atingir a sinergia esperada com a parceria ambas as empresas devem ser de tamanhos equivalentes, já que de outra forma uma delas pode ficar em desvantagem em relação à outra ou os benefícios seriam para uma delas muito limitados. É importante, portanto, definir claramente desde um início os benefícios que cada empresa quer atingir através desta união. 
Por outro lado, o uso de produtos normalizados agrega valor ao processo já que permite eliminar ou diminuir as etapas de especificação na compra e de controle de recebimento do produto na obra. A existência de normas técnicas constitui-se em fator básico para que o setor possa ter parâmetros confiáveis de referência para a comparação de produtos e processos. Além disso, facilita a troca de informações entre o fornecedor e a empresa construtora estabelecendo uma comunicação efetiva entre estes agentes e diminuindo em conseqüência os erros ocasionados por uma falta de entendimento entre eles.

No Brasil, apesar de ainda não existir um conjunto completo de normas em operação e apesar de a cultura de efetiva utilização de normas ainda ser baixa, o setor já vem se preocupando por este problema, sendo o órgão responsável pela normalização técnica a ABNT - Associação Brasileira de Normas Técnicas e o principal responsável pela elaboração, revisão e divulgação das normas técnicas do setor o COBRACON - Comitê Brasileiro de Construção Civil (CB-02).

Como foi comentado no Capítulo 2, a meta mobilizadora para o ano 2002 do PBQP-H prevê elevar para $90 \%$ o percentual médio de conformidade com as normas técnicas dos produtos que compõem a cesta básica de materiais de construção. Para cumprir esta meta o setor deverá contar com a participação ativa dos fabricantes (fornecedores), das empresas construtoras e, além disso, precisar-se-á do desenvolvimento de uma rede laboratorial equipada e capacitada para a análise e a avaliação de produtos e sistemas sob todos os aspectos do desempenho ao longo da vida útil.

Assim, o uso de produtos normalizados permite também uma inovação nos fluxos de informação já que diminui a quantidade de informação a ser processada para cada produto, além de diminuir e eliminar passos nas etapas de requisição, compra e 
recebimento. A identificação do material fica clara sem estar sujeita a ambigüidades, ganhando tanto a empresa construtora quanto a fornecedora.

Já o uso de tecnologias de informação como a Internet e os códigos de barras podem se converter também nos propiciadores da inovação nestes fluxos. Como já foi comentado, o potencial da Internet é muito extenso e vem sendo utilizado por diversas indústrias como meio de integração e comunicação com a conseqüente transformação dos fluxos de informações dentro delas.

Apesar do potencial da Internet estar atualmente limitado pela carência de formatos e padrões no que diz à troca de informações, privacidade e segurança, o mais provável é que nos próximos anos ela consiga conciliar estes pontos e se converta no meio de comunicação mais utilizado para realizar transações e operações de negócios.

Por outro lado, os códigos de barras, que vêm sendo utilizados de maneira intensiva na maioria das industrias e negócios, facilitam a identificação e o rastreamento de produtos. Através de um código e de um leitor é possível se identificar e se registrar rapidamente qualquer tipo de produto e integrá-lo a uma rede ou base de dados.

Apesar disso, nas empresas construtoras do país ainda não se verifica o uso desta tecnologia de informação, devido a limitações impostas pelo conjunto de agentes da cadeia produtiva. Nestas empresas, os códigos de barras poderiam agilizar o registro das entradas e saídas de materiais na obra e além disso poderiam servir para identificar os materiais que já estejam definidos desde a etapa de projeto facilitando a quantificação e requisição destes elementos. Na França, por exemplo, já existem empresas que incluem os códigos de barras nas plantas de projeto para a identificação de alguns elementos construtivos. 
Com respeito aos fluxos de informações relacionadas com a gestão de materiais, a Internet pode servir para centralizar as informações da obra e integrar tanto os participantes externos quanto os internos. Atualmente, a Internet oferece sítios de comércio eletrônico para produtos do setor e também disponibiliza softwares na área de projetos e outras. O uso destas aplicações vai implicar em uma reformulação dos fluxos de informações dentro das empresas da indústria e entre elas.

Através destas aplicações, por exemplo, as informações da obra e fornecedores e projetistas estariam centralizadas em um lugar único. O fato de se ter todas as informações centralizadas com uma codificação comum diminui substancialmente o tempo para fazer a requisição. Sendo que as informações adicionais necessárias (especificações, orçamentos, projetos, etc.) estariam também em rede, bastaria anexá-las à requisição. Com essa informação o programa encarregar-se-ia de juntar as requisições com pedidos similares, escolher os fornecedores qualificados (segundo a avaliação em rede) e enviar uma mensagem a eles solicitando a cotação. Desta forma, a requisição partiria da obra e chegaria diretamente ao fornecedor, e todas as etapas intermediárias seriam realizadas pelo sistema, modificando consequentemente os fluxos de informações.

É evidente que ainda existem muitos obstáculos a serem resolvidos antes disso acontecer. O exemplo dado no parágrafo anterior implica em uma reformulação dos fluxos de informações tanto dentro das empresas construtoras quanto dentro de seus fornecedoras, além dos que se processam entre eles. Não é somente uma questão de tecnologia mas principalmente da vontade das empresas em compartilhar e em padronizar suas informações. As empresas deverão estar conscientes de que mais cedo 
ou mais tarde deverão trabalhar conjuntamente em beneficio delas próprias e da indústria da construção civil como um todo (cadeia de suprimentos). 


\section{Conclusões}

Cumprindo com o objetivo principal desta pesquisa, no Capítulo 7 identificaram-se as principais diretrizes que os fluxos de informações relativos à gestão de materiais em empresas construtoras de edifícios deveriam possuir para garantir a eficácia e eficiência dos mesmos. Para tanto, estes fluxos foram analisados dentro de dois contextos:

- contexto macro: onde se partiu da hipótese de que estes fluxos faziam parte de um sistema maior e que estavam estreitamente relacionados com a estrutura organizacional da empresa, a mesma que determinava o caminho pelo qual circularia a informação e portanto influenciava na eficácia dos fluxos.

- Contexto específico à gestão de materiais: onde se assumiu que para garantir a eficiência dos fluxos seria necessário garantir a eficiência em cada uma das etapas pelas quais seria processada a informação.

A partir da análise em um contexto macro, chegou-se a quatro principais diretrizes. Primeiro, a formalização, tanto dos documentos internos da empresa (procedimentos) quanto de suas funções, constitui-se em um elemento indispensável para a racionalização dos fluxos de informação. Ao definir as regras de funcionamento da organização, a existência de procedimentos formalizados e de funções claramente definidas e dotadas dos recursos necessários ao seu funcionamento propicia uma otimização da capacidade de processamento de informações na empresa.

Segundo, sendo que a gestão de materiais abrange várias funções da empresa e, portanto, no momento de processar as informações nele envolvidas vai-se precisar de informações geradas no interior dessas, é recomendável que cada obra execute e controle suas informações para evitar uma dispersão das mesmas por toda a empresa. Uma configuração do tipo híbrida: funcional \& projetos passa ser a mais adequada para 
esta finalidade, ao permitir uma independência das obras, guardando para a empresa a centralização de funções julgadas estratégicas.

Terceiro, existindo a função suprimentos na empresa, este setor deve ser devidamente planejado e dotado de recursos para potencializar suas capacidades e não simplesmente atuar como um setor de compras.

Quarto, as TI utilizadas na empresa deveram apresentar um alinhamento estratégico com os seus objetivos estratégicos. Para tanto, cabe recordar que as TI precisam de gestão para potencializar seus benefícios. No caso da gestão de materiais, as novas TI estão indo ao encontro da integração tanto dentro da empresa quanto da cadeia de suprimentos. Apesar de que ainda existem alguns obstáculos para cumprir este objetivo, como por exemplo, a falta de padrões, as empresas devem começar a pensar que em um futuro próximo o papel das TI no setor será fundamental nos seus negócios e começar a se preparar para isso acontecer.

Quanto à análise no contexto específico, percorreu-se as etapas principais pelas quais circularam as informações afeitas à gestão de materiais, identificando-se as características dos seus principais elementos para que se garanta a eficiência em cada uma delas. Assim, para cada uma delas identificaram-se as características das informações de entrada, das informações adicionais e do agente ou mecanismo processador. Nas tabelas da 15 à 23 encontram-se resumidos estes resultados. A partir desta análise foi elaborado um fluxo de informações modelo (ver Figura 28, Figura 29 e Tabela 24), o qual inclui o uso de uma rede e uma base para o intercâmbio de informações dentro da empresa.

Por último, foram propostos alguns parâmetros que servissem para avaliar o sistema e conseguir uma melhoria contínua do processo, quais sejam: o tempo que leva o material 
da sua requisição até que chegue ao canteiro; a porcentagem relativa de atividades que não agregam valor; o custo de implementação e de manutenção do sistema; o número de ocorrências de não-conformidades em um determinado período; o tipo de nãoconformidade; e o grau de satisfação dos usuários internos do sistema.

Adicionalmente, as parcerias com os fornecedores, o desenvolvimento da normalização técnica e o uso de materiais em conformidade a elas, a Internet e os códigos de barras foram enxergados como uma forma de inovar os fluxos de informações e conseguir a integração tão almejada na cadeia de suprimentos.

Por outro lado, os objetivos secundários desta pesquisa foram obtidos ao longo dos demais capítulos. O primeiro destes objetivos, a caracterização dos fluxos de informações nas empresas construtoras, foi atingido através da pesquisa bibliográfica apresentada nos Capítulos 2 e 3. Enquanto que no Capítulo 2 resgatou-se os principais conceitos que explicam a gestão de materiais e sua importância na empresa construtora, no Capítulo 3 explicou-se a função dos fluxos de informações no interior das empresas.

Já o atingimento do segundo dos objetivos secundários, a identificação das possíveis interferências ou ruídos nos fluxos de informações relativos à gestão de materiais, deuse principalmente através do estudo de caso (Capítulo 6) onde consegui-se verificar de uma maneira prática os principais problemas apresentados nestes fluxos em cada uma das empresas estudadas.

Quanto ao terceiro e ao quarto destes objetivos, levantamento da bibliografia sobre sistemas de informação e identificação das TI que pudessem ser usadas para a otimização deste fluxos, estes foram atingidos através do Capítulo 4, onde se discutiu acerca da tecnologia de informação e do seu estado atual na indústria da construção e se 
identificaram algumas TI que poderiam servir para integrar as informações tanto internas quanto externas à empresa construtora.

Por último, o quinto objetivo secundário, a identificação das possíveis formas de racionalização dos fluxos de informações relativos à gestão de materiais, foi atingido ao longo de todos os capítulos mas principalmente no Capítulo 7, através da análise dos casos e da bibliografia.

Finalmente, resta por colocar alguns temas de pesquisa para trabalhos futuros que puderam ser identificados através desta pesquisa, quais sejam:

- $\quad$ sendo que nesta pesquisa focalizou-se principalmente nos fluxos de informações na empresa construtora, restaria por estudar mais profundamente os fluxos que se dão entre a empresa construtora e os fornecedores e por identificar as possíveis formas de racionalizá-los e integrá-los.

- Um outro tema poderia se constituir na formulação de um sistema de indicadores e parâmetros que servissem para garantir a melhoria contínua nos fluxos de informações relativos à gestão de materiais em empresas construtoras.

- Sendo que existe uma elevada probabilidade de que a Internet se constitua em um futuro próximo na forma mais utilizada para realizar troca de informações e realização de transações comerciais, considera-se também relevante se estudar como isso vai se refletir nos fluxos de informações nas empresas e como elas deverão se preparar para quando isso aconteça e, mais, de que modo elas poderiam agir para levar ao desenvolvimento dessa área segundo seus interesses.

- Uma outra linha de estudo, já apontada ao longo do texto, seria o desenvolvimento de padrões de interfaces comuns para subsidiar negócios eletrônicos no setor da 
construção civil, alinhado com as ações internacionais em curso, inclusive de outros setores.

- Finalmente, tendo se identificado vários gargalos que perturbam a gestão de materiais mas que dependem principalmente do setor (normalização de produtos, falta de infra-estrutura laboratorial, etc.), considera-se também interessante fazer um levantamento das principais iniciativas que vêm se dando no setor visando solucionar estes problemas e o estado atual das mesmas, sob a óptica da gestão dos fluxos e das informações. 


\section{Anexo.- Questionários empregados nos estudos de caso}

A seguir são apresentados os questionários utilizados nos estudos de caso:

\section{A) Questionário para o escritório central da empresa construtora \\ (i) Diretoria \\ (a) Perguntas Gerais}

1. Caracterização da empresa

$\square$ incorporadora

$\square$ construtora ambas

2. Áreas de atuação

$\square$ residencial - privado

$\square$ residencial- público

$\square$ comercial

$\square$ outros

3. Número de anos de atuação

4. Número atual de obras e caracterização destas:

5. Número total de obras executadas:

6. Número de empregados no setor administrativo e produtivo:

7. Qual é a missão da empresa?

8. A empresa está trabalhando com programas de implantação da Gestão da qualidade ou de racionalização da produção?

9. A empresa trabalha com mão-de-obra própria ou subempreitada?

(b) Tecnologia de Informação

1. Que tipos de TI utiliza a empresa, com que softwares trabalha?

2. Estes foram desenvolvidos especialmente para a empresa?

3. Estes softwares estão interligados ou eles trabalham independentemente?

4. Em média quantos micros existem por obra?

5. Principalmente qual é o uso destes micros nas obras?

6. A empresa tem Intranet? Que tipos de informações estão disponíveis nesta.

7. Que softwares usam para o área do suprimentos; em que consistem? 
8. As áreas de suprimentos e contabilidade estão interligadas?

(ii) Área de Suprimentos

(a) Cotações e compras

1. Quantas pessoas trabalham nesta área? Quais são suas funções?

2. Existe $(\mathrm{m})$ procedimento(s) formalizado(s) para esta área?

3. Quem é o responsável pela solicitação de cotação junto ao fornecedor?

4. Através de que meio de comunicação são enviadas estas solicitações?

5. Geralmente, quantas cotações são solicitadas por compra?

6. Existem formatos especiais para efetuar os pedidos de cotação?

$\square$ sim (solicitar a inclusão de uma copia). $\square$ não.

7. Através de que meios de comunicação são enviadas as cotações?

8. Depois de recebidas as cotações, quem decide a compra?

9. Como se efetua esta escolha; quais são os critérios mais importantes (custo, qualidade, pontualidade) ?

10. Existe algum tipo de avaliação de fornecedores? Quem participa desta avaliação?

11. Depois de escolhido o fornecedor, qual é o procedimento (documentos) para efetuar a compra? Através de que meios de comunicação realiza-se este procedimento?

12. Depois de quanto tempo a obra recebe confirmação da área de suprimentos do encaminhamento de seu pedido e da data de entrega?

$\square$ a obra somente fica sabendo quando o produto é entregue

$\square$ no mesmo dia

$\square$ menos de uma semana

uma semana

$\square$ mais de uma semana

Doutro

13. Como se faz a distribuição das compras?

$\square$ o fornecedor deixa cada pedido na obra.

$\square$ existe um almoxarifado central e os produtos são distribuídos à obra de acordo com as necessidades desta.

$\square$ alguns produtos são entregues na obra mas outros ficam no almoxarifado central.

$\square$ outro

14. Existem parcerias com fornecedores? 
$\square \operatorname{sim}$

15. Em que consistem estas parcerias?

16. Por que se optou por um área de suprimentos centralizada?

$\square$ otimizar custos

$\square$ ter centralizados os desembolsos

$\square$ ter centralizadas as informações

$\square$ ter maior controle sobre os desembolsos

$\square$ não carregar a obra com problemas contábeis

$\square$ outros

(b) Pagamentos

17. Quem é o encarregado pela efetuação dos pagamentos?

18. Quem é o encarregado pela autorização dos pagamentos?

19. Com base em quais documentos (requisitos) é autorizado o pagamento?

\section{B) Questionário para a obra}

Tipos de materiais :

A) Fôrmas e escoramentos

B) Aço e armaduras

C) Areia, agregados

D) Argamassas ensacadas, cimento e cal

E) Concreto estrutural

F) Elementos de alvenaria

G) Componentes de instalações elétricas

H) Componentes de instalações hidráulicas e sanitárias

I) Esquadrias

J) Revestimentos cerâmicos

K) Louças e metais

(i) Quantificação e planejamento inicial dos recursos

1. Quando é feita a quantificação inicial dos recursos?

$\square$ antes do início da obra

$\square$ no início da obra

outro.

2. Quem faz esta quantificação?

$\square$ área de suprimentos - centralizada

área de planejamento da empresa

$\square$ área de orçamento

eng. de obra

assistente em obra

$\square$ mestre

almoxarife

$\square$ outro 
3. A partir de quais documentos se faz esta quantificação inicial?

Dorçamentos

$\square$ quantificação com base nas plantas do projeto $\square$ outro

4. Onde fica registrada esta informação e quem é o responsável por ela?

5. Existe uma programação inicial (quantificação no tempo) dos recursos?

$\square \operatorname{sim}$

não (ir a pergunta 10)

6. Em que momento é feita a programação inicial de recursos?

$\square$ planejamento do empreendimento

$\square$ projeto

$\square$ já iniciada a obra

Joutro

7. Quem faz a programação inicial dos recursos?

$\square$ área de suprimentos - centralizada

$\square$ área de planejamento da empresa

eng. de obra

$\square$ assistente em obra

$\square$ mestre

$\square$ almoxarife

$\square$ outro

8. Quais documentos são necessários para fazer esta programação inicial?

$\square$ plantas de projeto

Jorçamento

cronograma de obra

quadro de desembolsos

outros

9. Onde fica registrada esta informação e quem é o responsável por ela ?

\section{(ii) Compras}

(a) requisição (produção $\leftrightarrow$ suprimentos)

10. Quem é o responsável pelo encaminhamento da requisição dos materiais na obra?

$\square$ engenheiro da obra

engenheiro assistente

administrador da obra

$\square$ estagiário

mestre

outro

11. Quem recebe esta informação?

$\square$ área de suprimentos da empresa

engenheiro da obra 
$\square$ engenheiro assistente
$\square$ administrador da obra
$\square$ outro

12. Como se realiza a comunicação entre eles?

$\square$ verbal, sem documentação escrita
$\square$ verbal, com documentação escrita
$\square$ telefone, sem documentação escrita
$\square$ telefone, depois confirmação por escrito
$\square$ fax
$\square$ computador
$\square$ carta
$\square$ outro

13. Existem formatos especiais para o encaminhamento destas requisições?

$\square \operatorname{sim}$ (solicitar inclusão de uma copia). $\square$ não.

14. Em geral, com base em que critérios se faz as requisições dos recursos:

$\square$ a primeira requisição se faz segundo a quantificação inicial e as demais são feitas segundo o requerimento da obra (não existe programação).

$\square$ no inicio da obra entrega-se um cronograma de necessidades, o qual é confirmado durante o transcurso da obra

$\square$ Existe uma programação feita no inicio da obra e outra periódica em função dos avanços das equipes de produção.

$\square$ outro.

15. Em que etapa da obra se fazem as requisições de compra?

\begin{tabular}{|l|c|c|c|c|c|c|c|c|c|c|c|}
\hline \multicolumn{1}{|c|}{ MATERIAL (ver lista acima) } & A & B & C & D & E & F & G & H & I & J & K \\
\hline Antes do inicio da obra & $\square$ & $\square$ & $\square$ & $\square$ & $\square$ & $\square$ & $\square$ & $\square$ & $\square$ & $\square$ & $\square$ \\
\hline Etapa de fundações & $\square$ & $\square$ & $\square$ & $\square$ & $\square$ & $\square$ & $\square$ & $\square$ & $\square$ & $\square$ & $\square$ \\
\hline Etapa de estruturas & $\square$ & $\square$ & $\square$ & $\square$ & $\square$ & $\square$ & $\square$ & $\square$ & $\square$ & $\square$ & $\square$ \\
\hline Etapa de alvenarias e revestimentos & $\square$ & $\square$ & $\square$ & $\square$ & $\square$ & $\square$ & $\square$ & $\square$ & $\square$ & $\square$ & $\square$ \\
\hline Etapa de acabamentos & $\square$ & $\square$ & $\square$ & $\square$ & $\square$ & $\square$ & $\square$ & $\square$ & $\square$ & $\square$ & $\square$ \\
\hline Outro & & & & & & & & & & & \\
\hline
\end{tabular}

16. Quantas requisições são feitas durante o transcurso da obra?

\begin{tabular}{|l|c|c|c|c|c|c|c|c|c|c|c|}
\hline \multicolumn{1}{|c|}{ MATERIAL (ver lista acima) } & A & B & C & D & E & F & G & H & I & J & K \\
\hline Pedido único & $\square$ & $\square$ & $\square$ & $\square$ & $\square$ & $\square$ & $\square$ & $\square$ & $\square$ & $\square$ & $\square$ \\
\hline $1-5$ & $\square$ & $\square$ & $\square$ & $\square$ & $\square$ & $\square$ & $\square$ & $\square$ & $\square$ & $\square$ & $\square$ \\
\hline $6-10$ & $\square$ & $\square$ & $\square$ & $\square$ & $\square$ & $\square$ & $\square$ & $\square$ & $\square$ & $\square$ & $\square$ \\
\hline $10-20$ & $\square$ & $\square$ & $\square$ & $\square$ & $\square$ & $\square$ & $\square$ & $\square$ & $\square$ & $\square$ & $\square$ \\
\hline$>20$ & $\square$ & $\square$ & $\square$ & $\square$ & $\square$ & $\square$ & $\square$ & $\square$ & $\square$ & $\square$ & $\square$ \\
\hline
\end{tabular}

17. Com que intervalos são feitos estas requisições?

\begin{tabular}{|l|c|c|c|c|c|c|c|c|c|c|c|}
\hline \multicolumn{1}{|c|}{ MATERIAL (ver lista acima) } & A & B & C & D & E & F & G & H & I & J & K \\
\hline Pedido único & $\square$ & $\square$ & $\square$ & $\square$ & $\square$ & $\square$ & $\square$ & $\square$ & $\square$ & $\square$ & $\square$ \\
\hline Diário & $\square$ & $\square$ & $\square$ & $\square$ & $\square$ & $\square$ & $\square$ & $\square$ & $\square$ & $\square$ & $\square$ \\
\hline Semanal & $\square$ & $\square$ & $\square$ & $\square$ & $\square$ & $\square$ & $\square$ & $\square$ & $\square$ & $\square$ & $\square$ \\
\hline
\end{tabular}




\begin{tabular}{|l|l|l|l|l|l|l|l|l|l|l|l|}
\hline 2 vezes por mês & $\square$ & $\square$ & $\square$ & $\square$ & $\square$ & $\square$ & $\square$ & $\square$ & $\square$ & $\square$ & $\square$ \\
\hline Mensalmente & $\square$ & $\square$ & $\square$ & $\square$ & $\square$ & $\square$ & $\square$ & $\square$ & $\square$ & $\square$ & $\square$ \\
\hline Mas de um mês & $\square$ & $\square$ & $\square$ & $\square$ & $\square$ & $\square$ & $\square$ & $\square$ & $\square$ & $\square$ & $\square$ \\
\hline
\end{tabular}

(b) Cotação (suprimentos $\leftrightarrow$ fornecedor) (Somente para área de suprimentos em obra)

18. Quem é o responsável pelas solicitações de cotações junto ao fornecedor?

$\square$ engenheiro da obra Dengenheiro assistente administrador da obra Joutro

19. Geralmente, quantas cotações são solicitadas por compra?

20. Através de que meios de comunicação solicita-se estas cotações?

$\square$ telefone, sem documentação escrita

$\square$ telefone, depois confirmação por escrito

$\square$ fax

$\square$ computador

$\square$ carta

$\square$ outro

21. Existem formatos especiais para efetuar as cotações?

$\square \operatorname{sim}$ (solicitar inclusão de uma copia). $\square$ não.

22. Depois de recebidas as cotações, quem decide a compra?

23. Como se efetua esta escolha; quais são os critérios mais importantes (custo, qualidade)?

24. Depois de escolhido o fornecedor, qual é o procedimento (documentos) para efetuar a compra? Através de que meios de comunicação se realiza este procedimento?

(c) Avaliação do fornecedor (Somente para área de suprimentos em obra)

25. Existe alguma avaliação de fornecedores? Em que consiste? Quem participa desta avaliação? Anexar documento procedimento.

26. Existem parcerias com fornecedores?

$\square \operatorname{sim}$

não

27. Em que consistem estas parcerias?

(d) Recebimento e locação de recursos na obra (obra $\leftrightarrow$ fornecedor)

(1) Pedido de entrega

28. Quem é o encarregado por pedir aos fornecedores a entrega dos materiais em obra? 


\begin{tabular}{l}
$\square$ engenheiro da obra \\
\hline$\square$ engenheiro assistente \\
$\square$ administrador da obra \\
$\square$ estagiário \\
$\square$ mestre \\
$\square$ outro
\end{tabular}

29. Como se realiza a comunicação com eles?

$\square$ verbal, sem documentação escrita

$\square$ verbal, com documentação escrita

$\square$ telefone, sem documentação escrita

$\square$ telefone, depois confirmação por escrito

$\square$ fax

$\square$ computador

$\square$ carta

$\square$ outro

30. Existem formatos especiais para estes pedidos?

$\square \operatorname{sim}$ (solicitar inclusão de copia).

$\square$ não.

31. Com que freqüência são passados os pedidos de entrega:

\begin{tabular}{|l|l|l|l|l|l|l|l|l|l|l|l|}
\hline $\begin{array}{c}\text { MATERIAL (ver lista } \\
\text { acima) }\end{array}$ & A & B & C & D & E & F & G & H & I & J & K \\
\hline Uma entrega total & $\square$ & $\square$ & $\square$ & $\square$ & $\square$ & $\square$ & $\square$ & $\square$ & $\square$ & $\square$ & $\square$ \\
\hline Diária & $\square$ & $\square$ & $\square$ & $\square$ & $\square$ & $\square$ & $\square$ & $\square$ & $\square$ & $\square$ & $\square$ \\
\hline Semanal & $\square$ & $\square$ & $\square$ & $\square$ & $\square$ & $\square$ & $\square$ & $\square$ & $\square$ & $\square$ & $\square$ \\
\hline 2 vezes por mês & $\square$ & $\square$ & $\square$ & $\square$ & $\square$ & $\square$ & $\square$ & $\square$ & $\square$ & $\square$ & $\square$ \\
\hline Mensalmente & $\square$ & $\square$ & $\square$ & $\square$ & $\square$ & $\square$ & $\square$ & $\square$ & $\square$ & $\square$ & $\square$ \\
\hline Mais de um mês & $\square$ & $\square$ & $\square$ & $\square$ & $\square$ & $\square$ & $\square$ & $\square$ & $\square$ & $\square$ & $\square$ \\
\hline Outro & $\square$ & $\square$ & $\square$ & $\square$ & $\square$ & $\square$ & $\square$ & $\square$ & $\square$ & $\square$ & $\square$ \\
\hline
\end{tabular}

(2) Entrega do pedido (fornecedor $\leftrightarrow$ obra)

32. Quem recebe os materiais em obra?

$\square$ engenheiro da obra

$\square$ mestre

$\square$ almoxarife

Destagiário

outro

33. Como identifica-se uma não-conformidade (anexar procedimentos onde constam os requisitos)?

$\square$ com base em critério ou experiência da pessoa encarregada pelo recebimento do material.

$\square$ com base em requisitos de conformidade documentados estabelecidos pela empresa

$\square$ no contrato especifica-se as características dos materiais

$\square$ outro 
34. Qual é o procedimento no caso de uma não-conformidade. A quem é comunicada esta não-conformidade?

35. Que documentos são utilizados na entrega dos materiais? Quem é o encarregado pelo seu arquivamento?

\section{(3) Distribuição dos materiais (obra)}

36. A distribuição dos materiais dentro do canteiro é realizado por:

$\square$ uma equipe encarregada de distribuir os materiais diariamente

as equipes de produção interessadas

$\square$ outros

37. Existe uma programação para a distribuição dos materiais com grua ou elevador?

$\square$ sim, especificar

não

(e) Pagamento (suprimentos $\leftrightarrow$ fornecedor) (Somente para área de suprimentos em obra)

38. Quem é o encarregado pela efetivação dos pagamentos das compras

engenheiro de obra

$\square$ administrador de obra

outro

39. Quem é o encarregado pela autorização dos pagamentos

40. Com base em que documentos (requisitos) é autorizado um pagamento?

41. Que área arquiva as faturas dos pagamentos?

42. Existe alguma retenção efetuada ao fornecedor como garantia?

(iii) Perguntas gerais

43. Quais são os principais problemas de logística que apresenta a obra :

os materiais não chegam a tempo à obra.

os pedidos são feitos com pouca antecipação. qualidade dos materiais não satisfatória.

não estão definidos os canais de comunicação para fazer pedidos; estes são informais.

$\square$ o fornecedor não cumpre com o solicitado (tempo, especificações).

existem perdas na movimentação.

existem perdas na estocagem.

$\square$ existe incerteza no avanço da produção; é muito difícil fazer uma programação de recursos com antecipação.

$\square$ a área de suprimentos da empresa tem um cronograma de entregas muito rígido, não sincronizado com o ritmo da obra.

$\square$ para que um pedido seja processado deve passar por muitas pessoas, o que faz com que uma ordem demore muito para chegar a seu destino. 
$\square$ alguns materiais chegam sem aviso, o que dificulta uma localização planificada no canteiro.

$\square$ os materiais são dispostos nos espaços disponíveis no momento.

Doutros.

44. Quais são os problemas mais comuns de comunicação que se apresentam :

$\square$ a comunicação na empresa é demasiadamente informal.

$\square$ não existem responsabilidades previamente definidas para cada cargo, estas são implícitas.

$\square$ o pedido passa por muitas pessoas, antes de ser emitido formalmente ao fornecedor.

$\square$ como não existem canais estabelecidos para o fluxo de um pedido, não existe um responsável direto ante a ocorrência de um problema.

$\square$ não existe documentação adequada que respalde o fluxo de informações.

$\square$ não existem meios físicos e canais que suportem o fluxo de informações (fax, e-mail, telefone).

45. Sugestões para resolver estes problemas

\section{C) Questionário para o fornecedor}

1) Sua empresa é:

$\square$ distribuidora

$\square$ produtora

ambas

2) Quais são os principais produtos que a sua empresa fornece?

3) O produto fornecido foi sempre o mesmo ou mudou? Por que?

4) Quantos anos têm a sua empresa no mercado?

5) Em quais regiões opera?

6) Quantas sucursais possui?

7) Quantas pessoas trabalham nela?

8) Seus principais clientes são:

$\square$ empresas construtoras de grande porte

$\square$ empresas construtoras de meio porte

$\square$ empresas construtoras pequenas

Dobras

distribuidores / varejistas

$\square$ distribuidores / atacadistas

outros

9) Em que áreas ou departamentos está dividida a sua empresa?

10) Atualmente, quantas obras estão sendo abastecidas pela sua empresa?

11) Qual é a capacidade anual máxima de produção da sua empresa? 
12) Quantos locais de armazenagem de produtos acabados possui a empresa (indicar localização)?

13) Que capacidades têm os locais de estocagem de seu produto? Normalmente em que porcentagem de sua capacidade estão?

14) Geralmente, quanto tempo fica estocado o produto?

15) O transporte utilizado para as entregues é próprio ou subempreitado?

16) Que tipo de transporte utiliza?

17) Qual é a informação necessária para poder elaborar a programação de suas entregas?

18) Com que freqüência é feita esta programação? Quem faz esta programação?

19) Quais são as principais fatores que podem interferir em sua programação, que dependem de seus clientes (obra ou empresa)?

$\square$ os pedidos são feitos com pouca antecipação.

$\square$ a informação entregue é incompleta, não indica claramente a data de entrega ou local de entrega.

$\square$ existe muita burocracia para aprovar uma pedido. Doutros.

20) Qual é o procedimento comum para fechar um contrato com uma empresa construtora ou obra? Qual é o caminho que deve recorrer a informação dentro de sua empresa desde que a recepção do pedido ate que o produto ser distribuído?

- Documentos (cotização, contrato, pagamento, prazos, etc.)

- Meios de comunicação

- responsáveis

21) Através de que meios de comunicação recebe os pedidos de seus clientes:

\begin{tabular}{l}
$\square$ telefone \\
$\square$ fax \\
$\square$ computador \\
\hline$\square$ carta \\
\hline$\square$ outro
\end{tabular}

22) Em quanto tempo se elabora uma cotação desde que esta é solicitada até ser entregue ao cliente.

23) Normalmente, quanto tempo demora desde a primeira cotação ser entregue ao cliente até se fechar o contrato?

24) Caso seu cliente seja uma empresa construtora, normalmente, quem faz os pedidos de cotações?:

\begin{tabular}{|l}
$\square$ obra \\
$\square$ suprimentos / empresa \\
$\square$ ambos
\end{tabular}


25) Em geral, com que área/pessoa da empresa/obra são feitas as transações?

$\square$ chefe de compras / central de suprimentos

$\square$ assistente / central de suprimentos

eng. residente / obra

$\square$ assistente / obra

outros

26) Do ponto de vista de sua empresa, o que é mais vantajoso, uma empresa construtora com área de suprimentos centralizada ou uma com obras com autonomia de compras? Por que?

27) Qual é a antecipação mínima necessária para que um cliente possa formular um pedido para que a sua empresa possa cumprir com uma entrega no prazo (considere o caso em que o seu estoque não cubra a demanda).

$\square$ mais de 1 mês

$\square 1$ mês

$\square 2$ semanas

1 semana

$\square 1$ dia

outro

28) Que tipo de informação recebe sua empresa quando o produto é entregue (guia de entrega, etc.)?

29) Depois de quanto tempo após da entrega do produto é feito o pagamento do mesmo?

30) A empresa outorga uma garantia de seus produtos? Em que consiste esta garantia? Aparece por escrito em algum documento?

31) Qual é o procedimento que se costuma fazer em caso de existir uma nãoconformidade identificada pelo seu cliente?

32) É possível pensar em uma entrega de seu produto JIT (Just-in-Time) ?

$\square \operatorname{sim}$

33) Por que?

34) Que teria que mudar em seus processos e nos processos de seu cliente para conseguir uma entrega de seus produtos JIT?

35) Têm trabalhado com alguma empresa construtora com uma forma de compra não convencional, envolvendo cotação, pedidos, recebimento, movimentação, estocagem?

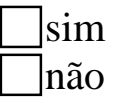

36) Pode descrevê-la? 
37) O senhor tem percebido ultimamente uma mudança de postura das empresas construtoras em relação aos fornecedores?

$\square \operatorname{sim}$

$\square$ não (continue na pergunta 39)

38) Quais são as principais mudanças percebidas (mais de uma resposta possível):

$\square$ maior exigência de qualidade

existe um maior controle no recebimento

$\square$ avaliação constante em termos de qualidade e cumprimentos de prazos

$\square$ as empresas têm procedimentos documentados indicando as especificações que deve ter o produto

$\square$ as empresas estão buscando parcerias com seus fornecedores

$\square$ outros

39) Alguma vez foi convidado a participar no planejamento e programação de alguma obra na qual sua empresa forneceu o material?

40) Existem parcerias com as empresas?

41) Como avalia o grau de satisfação de seus clientes? Existe algum procedimento documentado para avaliá-lo? (solicitar inclusão de copia) 


\section{Referências Bibliográficas}

AGAPIOU, A. et al. The role of logistics in the materials flow control process. Construction Management and Economics, v.16, n.2, p. 131-37, 1998a.

AGAPIOU, A; et al. The changing role of builders merchants in the construction supply chain. Construction Management and Economics, v.16, n.3, p. 351-61, 1998b.

AGOPYAN, V.; SOUZA, U.E.L.; PALIARI, J.C.; ANDRADE, A.C. Alternativas para a redução de desperdício de materiais nos canteiros de obras. Relatório final. PCC-USP/FINEP/ITQC, setembro de 1998. 5 volumes. 1355p.

AHMAD, I. U.; RUSSELL, J. S.; ABOU-ZEID, A. Information technology (IT) and integration in the construction industry. Construction Management and Economics. v.13, n.2, p.163-171,1995.

AIELLO, R. et al. Pour une Logistique des Chantiers, França, 1997.

AKINTOYE, A. Just-in-time application and implementation for building material management. Construction Management and Economics, v.13, n.2, p.105-13, 1995.

ASKIN, R. G.; STANDRIDGE, C. R. Modelling and analysis of manufacturing systems. USA, John Wiley and Sons. 1993.

AVENIR, M. J. Méthodes de terrain et recherche en management stratégique. Economies et Sociétés, Sciences et Gestion, n 14, p. 199-218, 1989.

ASSOCIAÇÃO BRASILEIRA DE NORMAS TÉCNICAS - ABNT. Sistemas de gestão da qualidade - Fundamentos e vocabulário - Projeto NBR ISO 9000, Rio de Janeiro, 2000a.

. Sistemas de gestão da qualidade - Requisitos - Projeto NBR ISO 9001, Rio de Janeiro, 2000b.

. Sistemas de gestão da qualidade - Diretrizes para melhorias de desempenho Projeto NBR ISO 9004, Rio de Janeiro, 2000c.

BALLARD, G.; HOWELL, G. Shielding production: essential step in production control. Journal of Construction Engineering and Management, v.121, n.1, p.11-17, Jan. / Feb., 1998.

BARROS, M. Metodologia para implantação de tecnologias construtivas racionalizadas na produção de edifícios. São Paulo, 1996. 422p. Tese (Doutorado) - Escola Politécnica da Universidade de São Paulo.

BARTON, P. et al. Information system in construction management - principles and applications. London, Batsford Academic and Educational, 1985.

BERNARDES, M.M.S. Método de análise do processo de planejamento do produção de empresas construtoras através do estudo de seu fluxo de informação: proposta baseada no estudo de caso. Porto Alegre, 1996. Dissertação (Mestrado) - Escola de Engenharia CPGEC Universidade Federal do Rio Grande do Sul. 
BERTELSEN, S. Building logistics: a mean for improvement of productivity in the building sector, unpublished paper, Denmark, 1995.

BERTELSEN, S.; NIELSEN, J. Just-in-time logistics in the supply of building materials. In: INTERNATIONAL CONFERENCE ON CONSTRUCTION INDUSTRY DEVELOPMENT: BUILDING THE FUTURE TOGETHER, 1., Singapore 1997. Proceedings. Singapore, 1997. p.310-18.

BIO, S. R. Sistemas de informação: um enfoque gerencial. São Paulo, Atlas, 1985.

BOWERSOX, D.; CLOSS, D.; HELFERICH, O. Logistical management : a system integration of physical distribution, manufacturing support and materials procurement. USA, Macmillan Publishing Company, 1986.

BURCH, J.; STRATER, F.; GRUDNITSKI, G. Information systems: theory and practice. USA, John Wiley \& Sons, 1979.

BURTON, R.; OBEL, B. Strategic organisational diagnosis and design. USA, Kluwer Academic Publishers, 1995.

CARDOSO, F. Stratégies d'entreprises et nouvelles formes de rationalisation de la production dans le bâtiment au Bresil et en France. Paris, 1996a. 478p. Tese (Doutorado) - École Nationale des Ponts et Chaussées.

CARDOSO, F. Importância dos estudos de preparação e da logística na organização dos sistema de produção de edifícios: alguns aprendizados a partir da experiência francesa. In: SEMINÁRIO LEAN CONSTRUCTION - A CONSTRUÇÃO SEM PERDAS, 1., São Paulo, 1996b. Anais. São Paulo, 1996b.

CARVAlHO, M.; BERNARDES, M.; FORMOSO, C. Programação de recursos: uma intervenção em seu sistema de informação. In: ENCONTRO NACIONAL DE TECNOLOGIA DO AMBIENTE CONSTRUÍDO, QUALIDADE NO PROCESSO PRODUTIVO, VII., Florianópolis, 1998. Anais. Florianópolis, 1998.

CHANDLER, A. D. Strategy and structure: chapters in the history of the industrial enterprise. Cambridge, Massachusetts and London, England, The MIT Press, 1962.

CHARETTE; M. UNIFORMAT II elemental classification for building specifications, cost estimating, and cost analysis. USA, US Department of Commerce, 1999.

CHIAVENATO, I. Introdução à teoria geral da administração. 5. ${ }^{a}$ edição, São Paulo, Makron Books, 1997.

CHRISTOPHER, M. Logistics and supply chain management: strategies for reducing costs and improving services. London, Pitman, 1992.

CLARK, A. et al. Benchmarking the use of IT to support supplier management in construction. Electronic Journal of Information Technology (http://itcon.org/1999/1/), Itcon, vol4, p.1-18, 1999.

COUNCIL OF LOGISTICS MANAGEMENT (CLM) Definição da logística. Disponível na Internet http://www.clm1.org/Mission/Logistics.asp, acesado em novembro do 2000 .

CONSTRUCTION SPECIFICATION CANADA (CSC) - Formats disponível na Internet, http://www.csc-dcc.ca/publicat/cat2-6.htm, acesado em setembro do 2000. 
DAVIS, G.; OLSON, M. Management information systems: conceptual foundations structure and development. USA, Mc Graw-Hill, 1985.

DAVIS, T. Effective supply chain management. Sloan Management Review, p.3546, Summer, 1993.

DE MARCO, T. Structured analysis and system specification. New York, Yourdon Press, 1979.

DOBLER, D.; BURT, D. Purchasing and supply management. USA, Mc-Graw Hill Companies, 1996.

ETZIONI, A. Organizações Modernas. São Paulo, Pioneira, 1964.

GALBRAITH, J. Organization design: an information processing view. Interfaces, v.2, n.3, p.28-36, 1974.

GANE, C.; SARSON, T. Structured system analysis: tools and techniques. USA, Prentice Hall, Inc., 1979.

GOETSCH, D.; DAVIS, S. Introduction to total quality: quality, productivity, competitiveness. Singapore, Prentice Hall International Editions, 1994.

GUERRINI, F. Um sistema de administração da produção (SAP) para empresas de pequeno e médio porte da construção civil. São Carlos 1997. 164p. Dissertação (Mestrado) - Escola de Engenharia de São Carlos da Universidade de São Paulo.

GURGEL, F. Administração dos fluxos de materiais e produtos. São Paulo, Atlas, 1996.

HAGA, H; SACOMANO, J.B. Gestão da rede suprimentos na construção civil integração a um sistema de administração da Construção. In: CONGRESSO LATINO- AMERICANO: TECNOLOGIA E GESTÃO NA PRODUÇÃO DE EDIFÍCIOS, SOLUÇÕES PARA O TERCEIRO MILÊNIO, São Paulo, 1998. Anais. São Paulo, EPUSP, 1998, v1, p. 227-34.

HALL, R. Organizations : structure and process. New Jersey, Prentice-Hall, 1972.

HALSALL; F. Data communications computer networks and open systems. USA, Addison Wesley Publishers Ltd, 1996.

HEINECK, L. F. M; TRISTÃO, A. M. D.; NEVES, R.M. das. Problemas em uma empresa de construção e em seus canteiros de obras. In: CONGRESSO NACIONAL DE ENGENHARIA DE PRODUÇÃO, São Carlos, 1995. Anais. São Carlos, UFSCar, 1995, p.841-45.

HENDERSON, J.C.; VENKATRAMAN, N. Strategic alignment: leveraging information technology for transformation organizations. IBM systems journal, v32, n.1, p. 4-16, 1993.

ISO 9000:2000. Quality management systems: fundamentals and vocabulary (working draft), 1999.

JOHNSON, J.; WOOD, D. Contemporary logistics. New Jersey, Prentice Hall International Editions, 1996.

KOSKELA, L. Application of the new production philosophy to construction (Technical Report No 42), Center for integrated facility engineering, Stanford University, USA, 1992. 
LA LONDE, B. Evolution of the integrated logistics concept. The Logistics Handbook, New York, J.F. Robenson \& William C. Copacino, p. 3-12, 1994.

LONDON, K; KENLEY, R; AGAPIOU, A. Theoretical supply chain network modelling in the building industry. ARCOM, Reading, 1998.

LUCAS, H. Information technology for management, USA, McGraw Hill Companies, 1997.

MASTERS, J.; POHLEN, T. Evolution of the logistics profession. The logistics handbook. New York, J.F. Robenson \& William C. Copacino, p.13-34, 1994.

McFARLAN, W. F. Information technology changes the way that you compete. Harvard Business Review, v62, n3, p.98-103, 1984.

McGREGOR, D. The human side of enterprise. New York, McGraw-Hill, 1960.

MELHADO, S. B. Qualidade de projeto na construção de edifícios: aplicação ao caso das empresas de incorporação e construção. São Paulo, 1994. 294p. Tese (Doutorado) - Escola Politécnica da Universidade de São Paulo.

MELHADO, S; AGOPYAN, V. O conceito de projeto na construção de edifícios: diretrizes para sua elaboração e controle. BT/PCC/139. São Paulo 1995.

MILES, R; SNOW, C. Organizations: new concepts for new forms. California Management Review, v. xxviii, n.3, p.62-92, 1986.

MINTZBERG, $\mathrm{H}$. Criando organizações eficazes - estruturas em cinco configurações. São Paulo, Atlas, 1995.

O'BRIEN, M.; AL-SOUFI, A. Electronic data interchange and the structure of the UK construction industry. Construction Management and Economics, v.11, p.44353, 1993.

O'BRIEN W. Construction supply chains: case study and integrated cost and performance anaysis. In: CONFERENCE OF THE INTERNATIONAL GROUP FOR LEAN CONSTRUCTION, 3., New Mexico, 1995. Proceedings. New Mexico, 1995. p.187-222.

ORLICK, J. Materials requirement planning. New York, McGraw-Hill., 1975.

PALACIOS, V.H.R. Metodologia para desenvolvimento de programas de melhoria da qualidade em empresas de construção de pequeno porte: uma aplicação no setor de suprimentos. Rio Grande do Sul, 1994. Dissertação (Mestrado) Universidade Federal do Rio Grande do Sul.

PORTER, M.; MILLAR, V. How information gives you competitive advantage. Harvard Business Review, v.63, n4, p.149-60, 1985.

PICCHI, F. Sistemas da qualidade: uso em empresas de construção de edifícios. São Paulo 1993. 462p. Tese (Doutorado) - Escola Politécnica da Universidade de São Paulo.

ROSETTANET Lingua franca for e-bussiness. executive overview. Disponível na Internet http://rosettanet.org/general/overview.html, acessado em setembro de 2000. 
SABBATINI, F. H. A industrialização e o processo de produção de vedações: utopia ou elemento de competitividade empresarial. In: SEMINÁRIO TECNOLOGIA E GESTÃO NA PRODUÇÃO DE EDIFÍCIOS, VEDAÇÕES VERTICAIS. São Paulo, 1998. Anais. São Paulo, 1998. p.1-19.

SACOMANO, J. B.; GUERRINI, F. M. Sistemas de administração da produção e a construção civil. Gerenciamento da Construção Civil. Ed. Edmundo Escrivão Filho, São Carlos: EESC - Projeto REENGE, 1998.

SANTOS, A. Metodologia de intervenção em obras de edificações enfocando o sistema de movimentação e armazenamento de materiais: um estudo de caso. Porto Alegre, 1995. 145p. Dissertação (Mestrado) - Escola de Engenharia CPGEC Universidade Federal de Rio Grande do Sul.

SAURIN, T. A. Método para diagnóstico e diretrizes para planejamento do canteiro de obra de edificações. Porto Alegre, 1997. 171p. Dissertação (Mestrado) - Escola de Engenharia CPGEC / Universidade Federal do Rio Grande do Sul.

SCHERMERHOR, J.; HUNT J.; OSBORNE, R. Managing organizational behavior. New York, John Wiley \& Sons, Inc., 1994.

SILVA, F. B. A logística na organização dos sistemas de produção de edifícios: conceitos e diretrizes. São Paulo, 2000a. 206p. Dissertação de Mestrado - Escola Politécnica da Universidade de São Paulo.

SILVA, F. B.; CARDOSO, F. F. Diagnóstico da logística em empresas de construção de edifícios. In: CONGRESSO LATINO AMERICANO, TECNOLOGIA E GESTÃO NA PRODUÇÃO DE EDIFÍCIOS, SOLUÇÕES PARA O TERCEIRO MILÊNIO, São Paulo, 1998. Anais. São Paulo, 1998. p.253-60.

SILVA, M. A. C. Necessidades de ações de desenvolvimento tecnológico na produção da construção civil e da construção habitacional. In: Fórum da Indústria da Construção Civil, São Paulo, Outubro 2000b.

SIMON H. The new science of management decision. USA, Harper \& Row Publishers, 1960.

SIMPÓSIO NACIONAL: DESPERDÍCIO DE MATERIAIS NOS CANTEIROS DE OBRAS: a quebra do mito. Anais. São Paulo, Ed. SOUZA, U.; AGOPYAN, V.; PALIARI, J. C.; ANDRADE, A. 1999.

SIQUEIRA, D. M. R. A informatização do controle da qualidade na área de recebimento e inspeção de materiais. São Carlos, 1998. 158p. Dissertação (Mestrado) - Escola de Engenharia de São Carlos -Universidade de São Paulo.

SOUZA, R.; MEKBEKIAN, G.; SILVA M.A.; LEITÃO A. C.; SANTOS, M. Sistema de gestão da qualidade para empresa construtoras. São Paulo, Ed. Pini, 1995.

STUKHART, G. Construction materials management. USA, Marcel Dekker INC., 1995.

THOMAS, S.; TUCKER, R.; KELLY, W. Critical communications variables. Journal of Construction Engineering and Management, v.124, n.1,. p.58-66, Jan. / Feb 1998. 
VIVANCOS, A. Estruturas organizacionais de empresas construtoras de edificações e a implantação de sistemas de gestão da qualidade: caracterização e processo de mudança. São Paulo, 2000. Exame de Qualificação (Mestrado) Escola Politécnica da Universidade de São Paulo.

VIVANCOS, A.; CARDOSO, F. Impacts of the implementation of quality management systems in the organizational structure of Brazilian building construction firms. In: IMPLEMENTATION OF CONSTRUCTION QUALITY AND RELATED SYSTEMS: A GLOBAL UPDATE, TG 36 CIB, Portugal, 2000. Proceedings. Portugal, 2000.

VRIJHOEF, R; KOSKELA, L. Roles of supply chain management. In: CONFERENCE OF THE INTERNATIONAL GROUP FOR LEAN CONSTRUCTION, 7. Berkeley, 1999. Proceedings. Berkeley, 1999. p. 133-46. 